OSCAR TADASHI KINTO

\title{
METODOLOGIA PARA O PIR EM AMBIENTE CORPORATIVO PARA O RECURSO ENERGÉTICO DA GASEIFICAÇÃO DE BIOMASSA
}

\author{
Dissertação apresentada à Escola \\ Politécnica da Universidade de São \\ Paulo para obtenção do título de \\ Mestre em Engenharia
}


OSCAR TADASHI KINTO

\section{METODOLOGIA PARA O PIR EM AMBIENTE CORPORATIVO PARA O RECURSO ENERGÉTICO DA GASEIFICAÇÃO DE BIOMASSA}

Dissertação apresentada à Escola

Politécnica da Universidade de São

Paulo para obtenção do título de

Mestre em Engenharia

Área de Concentração:

Sistema de Potência

Orientador:

Prof.Dr. Miguel Edgar Morales Udaeta

São Paulo

2012 
Este exemplar foi revisado e alterado em relação à versão original, sob responsabilidade única do autor e com a anuência de seu orientador.

São Paulo, de novembro de 2012.

Assinatura do autor

Assinatura do orientador

Kinto, Oscar Tadashi

Metodologia para o PIR em ambiente corporativo para o recurso energético da gaseificação de biomassa / O.T. Kinto. ed.rev. -- Săo Paulo, 2012.

$156 \mathrm{p}$.

Dissertação (Mestrado) - Escola Politécnica da Universidade de São Paulo. Departamento de Engenharia de Energia e Automação Elétricas.

1. Indústria de celulose e papel 2. Gaseificação 3. Biomassa 4. Planejamento integrado de recursos 5 . Recursos do lado da oferta I. Universidade de São Paulo. Escola Politécnica. Departamento de Engenharia de Energia e Automação Elétricas II. t. 
Dedico este trabalho aos meus pais, Kazuo Kinto e Yasuko Kinto, que me apoiaram durante todo o período acadêmico e não pouparam esforços para investir em minha educação. 


\section{AGRADECIMENTOS}

Agradeço ao professor Miguel Udaeta pelo constante estímulo e pela orientação, opoiando-me e incentivando-me durante todo o trabalho.

A todos da equipe do PIR, em especial a Flávio Minoru, Pascoal Rigolin e Ricardo Baitelo, por compartilharem seus conhecimentos durante a etapa de estudos e pesquisas.

Aos meus amigos Eduardo Oshiro, Jaime Kikuchi, Jorge Luiz e Marcílio Pires, que me contribuíram com informações para a realização deste trabalho.

Ao meu irmão Eduardo Akira Kinto, que me apoiou para a conclusão deste trabalho, e a toda minha família.

Agradeço aos meus colegas de trabalho que me incentivaram para a realização deste trabalho. 


\section{RESUMO}

O objetivo deste trabalho é aplicar a metodologia do Planejamento Integrado de Recursos energéticos (PIR) dentro do ambiente corporativo. Para estudo de caso foi escolhida uma indústria de papel e celulose, por se tratar de uma das indústrias de maior consumo energético, e a região onde ela está instalada, o município de Suzano. Inicialmente, procurou-se descrever o processo produtivo em uma indústria de papel e celulose. Para este trabalho foi analisado somente os recursos do lado da oferta. Além dos recursos tradicionais, que são a caldeira de biomassa, a caldeira de gás natural/óleo combustível e as caldeiras de recuperação, foi incluída uma nova tecnologia, a gaseificação de biomassa. Foram descritas as tecnologias de gaseificação disponíveis e mostrado o seu estado da arte. Dentro dessas tecnologias, há uma aplicação que busca substituir as tecnologias atuais de caldeira de recuperação, a gaseificação de licor negro.

Palavras-chave: Planejamento Integrado de Recursos, indústria de papel e celulose, gaseificação de biomassa, Recursos do Lado da Oferta. 


\begin{abstract}
The purpose of this study was to apply the Integrated Resources Planning for Energy (IRP) methodology within corporate environment. A study of case of pulp and mill industry was chosen, because it is one of largest energy consumption industries, and the region that was studied was Suzano. Inicially we described the industrial process of pulp and mill factory. This study we will analyze only the features of Supply Side Resources. In addition to the traditional power supplies which are biomass boiler, natural gas/fuel oil boiler and recovery boiler, we include a new technology, biomass gasification. We described the technologies available for gasification and show the state of art of this technology. Within these technologies, we have an special application the seeks to replace currently technology of recovery boiler, Black Licor Gasification.
\end{abstract}

Keywords: Integrated Resource Planning, pulp and mill factory, biomass gasification, Supply Side Resource. 


\section{LISTRA DE ILUSTRAÇÕES}

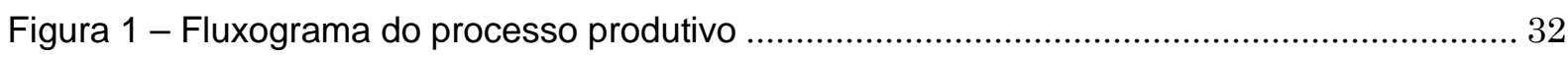

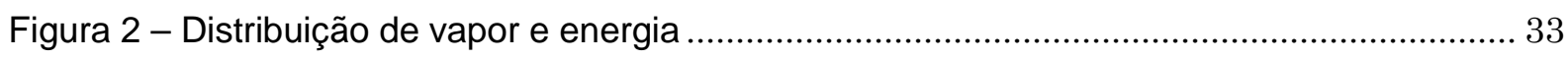

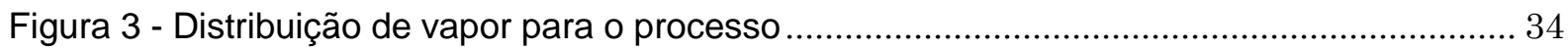

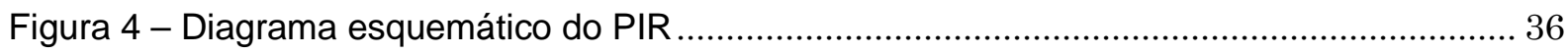

Figura 5 - Fontes e características dos principais poluentes na atmosfera ............................... 41

Figura 6 - Estimativa da frota de veículos da RMPS (região metropolitana de SP) em 2010 ..... 43

Figura 7 - Estimativas de emissão das fontes de poluição do ar na RMSP ................................ 44

Figura 8 - Classificação de saturação e graduação de severidade para os municípios da UGRHI 6

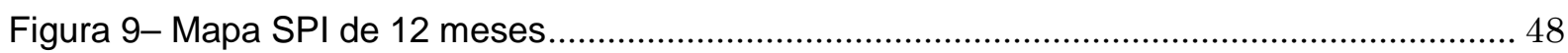

Figura 10- Velocidade média trimestral a $50 \mathrm{~m}$ de altura ........................................................... 50

Figura 11- Direções predominantes ....................................................................................... 51

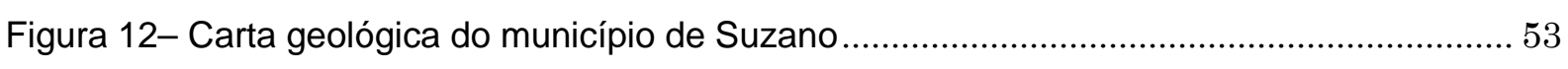

Figura 13 - Mapa da UGRHI 6 - Índice de qualidade de aterro resíduos ................................... 56

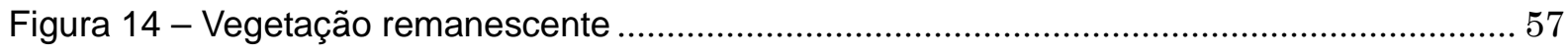

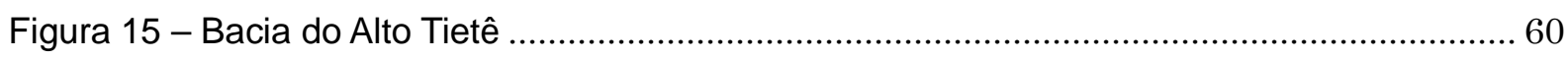

Figura 16 - Rede de monitoramento da rede básica UGRHI 6 e 7 .............................................. 61

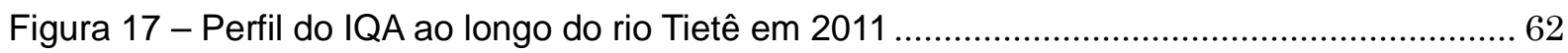

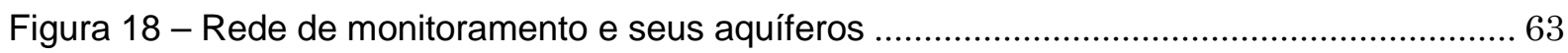

Figura 19 - Mapa de qualidade das águas superficiais em Suzano .......................................... 64

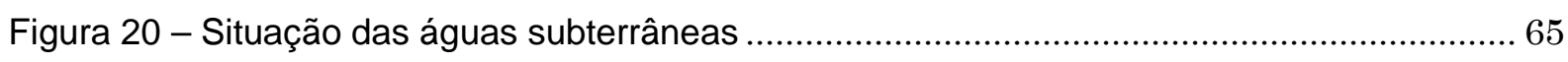

Figura 21 - Divisão de distritos do município de Suzano segundo Censo de 2000 ...................... 68

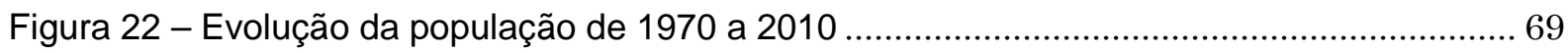

Figura 23 - Distribuição da população por sexo, município de Suzano, na parte superior, e estado

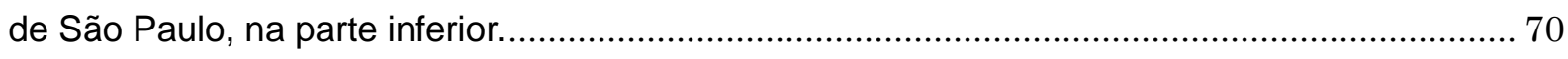

Figura 24 - Distribuição da população entre rural e urbano......................................................... 71

Figura 25 - Região metropolitana de São Paulo e o município de Suzano.................................... 72

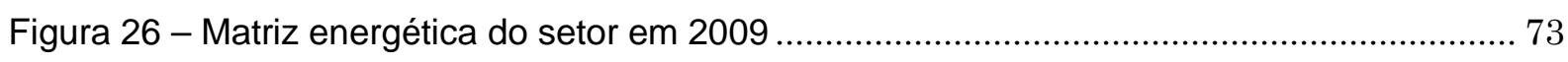

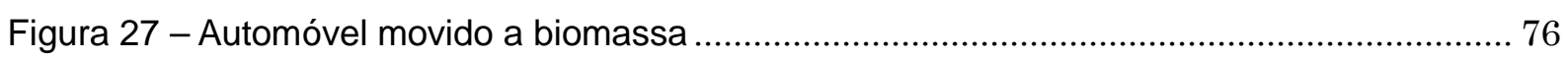

Figura 28 - Composição do gás combustível .............................................................................. 78

Figura 29 - Faixa de aplicação para diferentes tipos de gaseificadores de biomassa................. 79

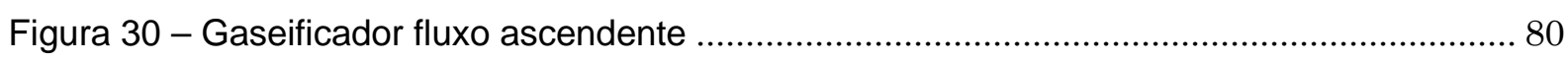

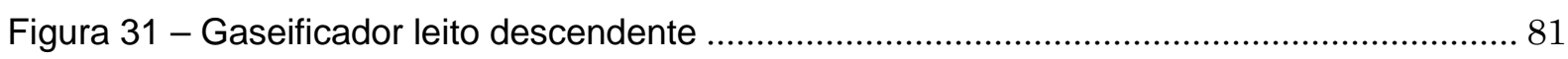

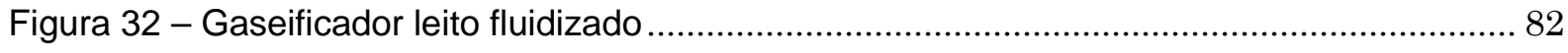

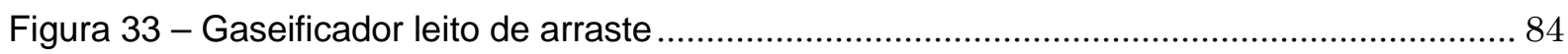


Figura 34 - Esquema simplificado do processo Kraft usado em um processo tradicional Fonte: [1] 2003

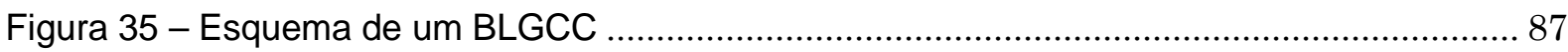

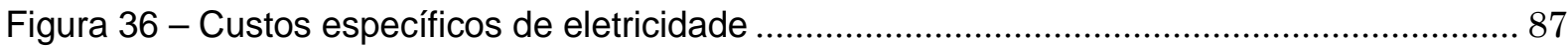

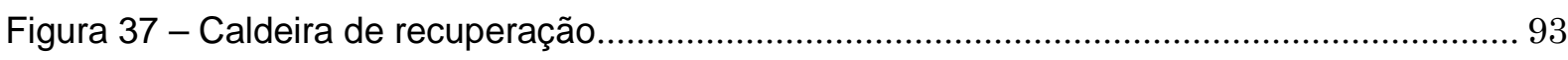

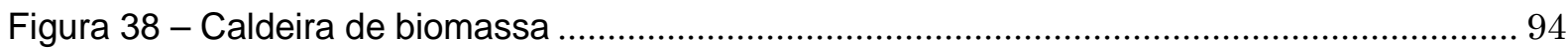

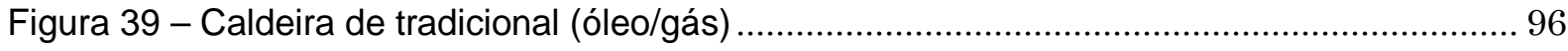

Figura 40 - Usinas Amador Aguiar I (superior) e Amador Aguiar II (inferior) ................................ 97

Figura 41 - Processo de geração e distribuição de energia elétrica............................................. 98

Figura 42 - Árvore de atributos e subatributos da dimensão técnico-econômica ........................ 100

Figura 43 - Árvore de atributos e subatributos da dimensão política ........................................ 105

Figura 44 - Árvore de atributos e subatributos da dimensão social........................................... 108

Figura 45 - Árvore de atributos e subatributos da dimensão ambiental .................................... 112

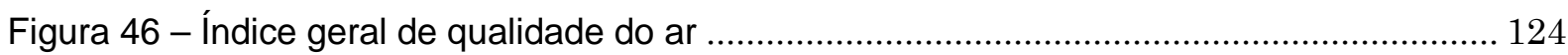

Figura 47 - Emissões e remoções de GEE do estado de São Paulo ......................................... 126

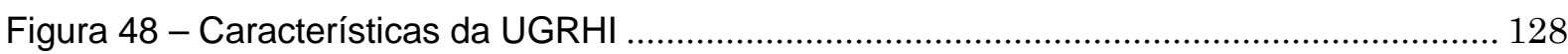

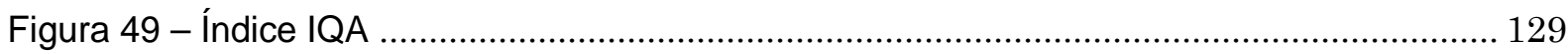

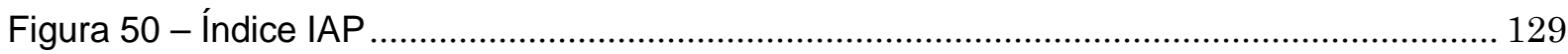

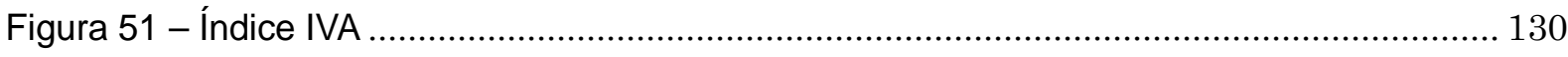

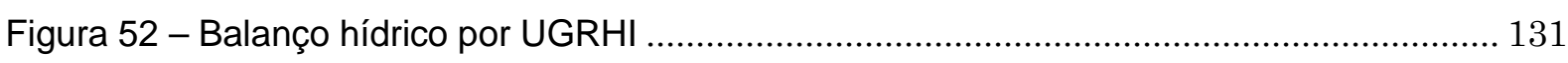

Figura 53 - Expectativa de crescimento de demanda de celulose ............................................ 136

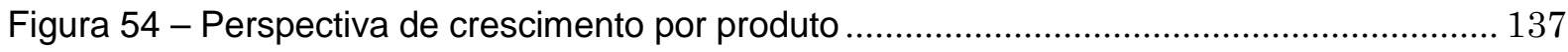

Figura 55 - Gráfico de consumo de energia na unidade de Suzano e suas projeções.............. 138

Figura 56 - Gráfico dos recursos da oferta para atendimento do incremento de demanda energética (GWh) 


\section{LISTA DE TABELAS}

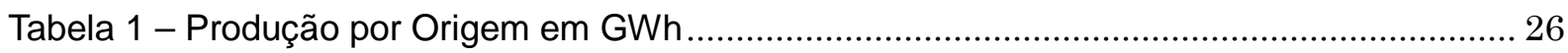

Tabela 2 - Empreendimentos utilizando os combustíveis de classe biomassa ............................ 27

Tabela 3 - Desempenho do setor de papel e celulose (em mil toneladas) no Brasil.................... 27

Tabela 4 - Matriz energética da Indústria Papel e Celulose (\%) ................................................... 28

Tabela 5 - Emissões potenciais de $\mathrm{CO}_{2}$ provenientes da queima de combustível e da produção

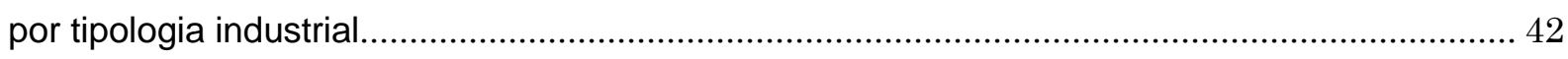

Tabela 6 - Estimativas de emissão (ton/ano) das fontes de poluição do ar em Suzano ............... 45

Tabela 7 - Emissão de GEE no setor de papel e celulose ........................................................... 47

Tabela 8 - Relação entre SPI e a categoria de seca.................................................................. 48

Tabela 9 - Áreas contaminadas no município de Suzano ......................................................... 55

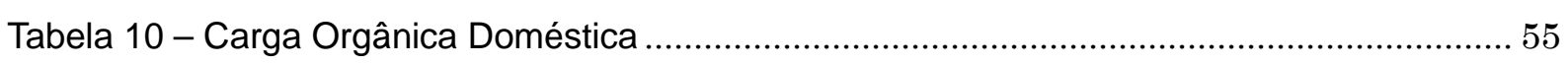

Tabela 11 - Disposição final de resíduos sólidos domésticos ..................................................... 56

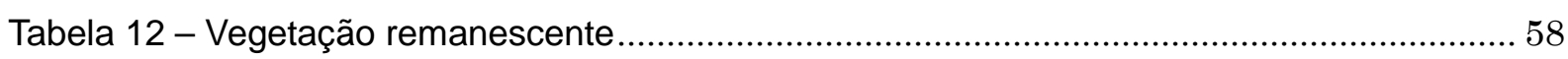

Tabela 13 - Consumo de energia direta e indireta (GJ) no setor de papel e celulose ................. 74

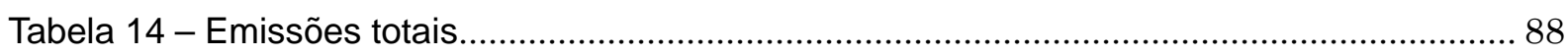

Tabela 15 - TIR e VPL de caldeira da recuperação e gaseificadores de licor negro................... 101

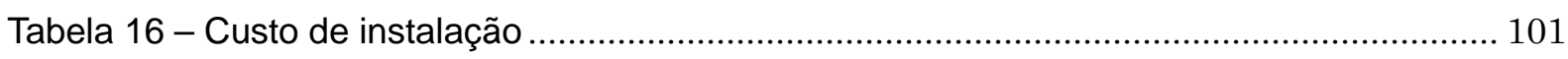

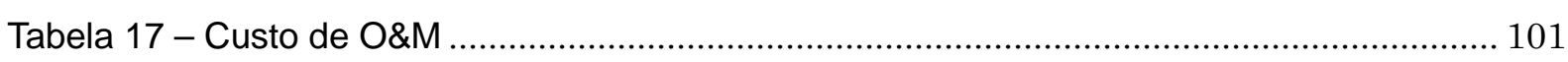

Tabela 18 - Emissões atmosféricas típicas de caldeiras de recuperação .................................. 114

Tabela 19 - Emissões de poluentes, caldeiras de recuperação e gaseificadores ...................... 115

Tabela 20 - Resultado ranqueamento determinístico ............................................................... 119

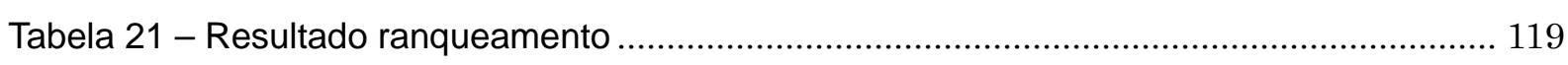

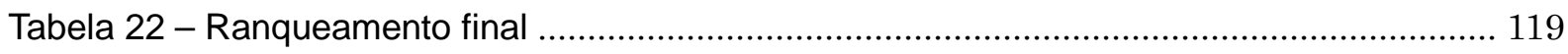

Tabela 23 - Dados primários relativos ao meio antropogênico - Território e População ............ 121

Tabela 24 - Dados primários relativos ao meio antropogênico - Condições de vida .................. 121

Tabela 25 - Dados primários relativos ao meio antropogênico - Economia............................... 121

Tabela 26 - Dados primários relativos ao meio antropogênico - Educação................................ 121

Tabela 27 - Dados primários relativos ao meio antropogênico - Habitação e Infraestrutura..... 122

Tabela 28 - Dados primários relativos ao meio antropogênico - Empregos e Rendimentos..... 122

Tabela 29 - Dados primários relativos ao meio antropogênico - Saúde .................................... 122

Tabela 30 - Dados primários relativos ao meio antropogênico - Meio Ambiente e Política Urbana

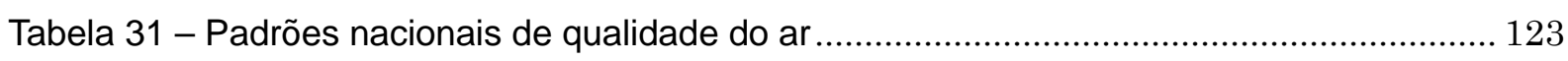

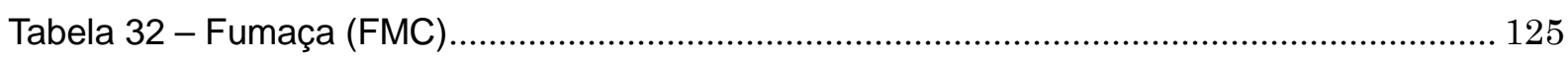

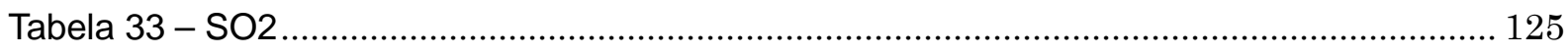

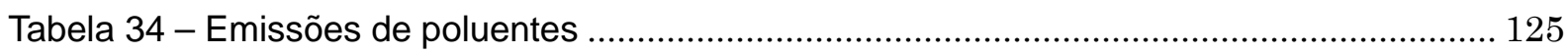


Tabela 35 - Emissões da indústria de papel e celulose de São Paulo 127

Tabela 36 - Dados de saneamento básico do município de Suzano. 129

Tabela 37 - Pontos de medição do município de Suzano 129

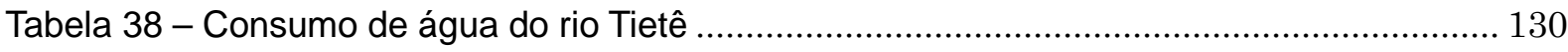

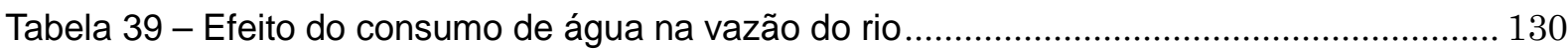

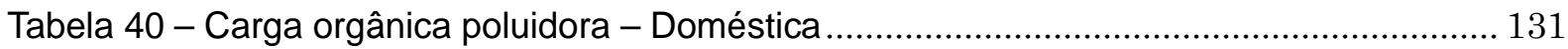

Tabela 41 - Indicador de potabilidade das águas subterrâneas ................................................. 132

Tabela 42- Área de vegetação nativa por UGRHI em 2005 e 2008/2009 ................................... 132

Tabela 43 - Área de mata ciliar declarada no estado de São Paulo por UGRHI até 2010 ........ 133

Tabela 44 - Número de áreas contaminadas cadastradas no estado de São Paulo .................. 133

Tabela 45 - Número de áreas contaminadas cadastradas no estado de São Paulo e por tipo de

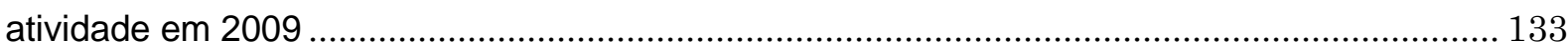

Tabela 46 - Índice de reabilitação e classificação das áreas contaminadas em 2009 ............... 134

Tabela 47 - Distribuição dos acidentes relacionados a desastres naturais por tipo e consequência

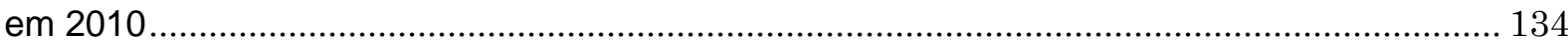

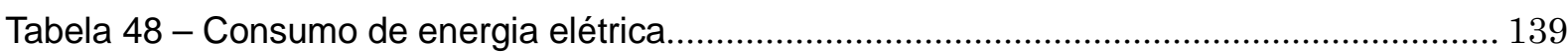

Tabela 49 - Recursos de oferta $\mathrm{x}$ Incremento da demanda (MWh) ........................................... 140

Tabela 50 - Recursos da oferta x Incremento da demanda (MWh) .......................................... 143

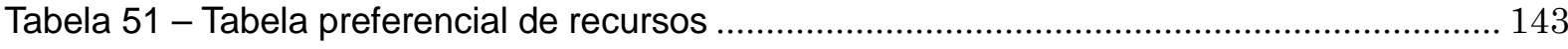

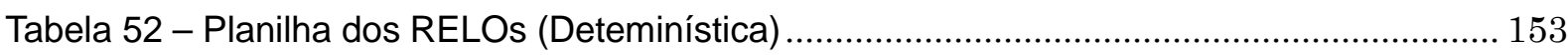

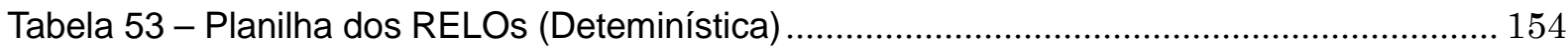

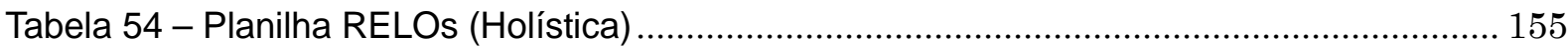

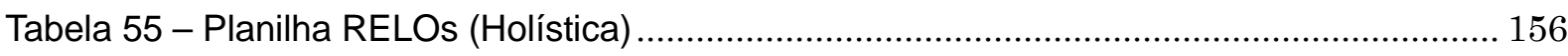




\section{LISTA DE ABREVIAÇÕES}

BIG-GTCC Biomass Integrated Gasifier-Gas Turbine Combined Cycle

BLGCC Back Liquor Gasification Combined Cycle

CCBE Consórcio Capim Branco Energia

CEDEC Centro de Estudos de Cultura Contemporânea

CETESB Companhia de Tecnologia de Saneamento Ambiental

CONAMA Conselho Nacional do Meio Ambiente

CPLA Coordenadoria de Planejamento Ambiental

CPTM Companhia Paulista de Trens Metropolitanos

CVRD Companhia Vale do Rio Doce

DBO5 Demanda Bioquímica de Oxigênio (5 dias)

DQO Demanda Química de Oxigênio

DENATRAN Departamento Nacional de Trânsito

ECF Elemental Chlorine Free

EPUSP Escola Politécnica da Universidade de São Paulo

ETA Estações de Tratamento de Água

ETE Estações de Tratamento de Efluentes

EUA Estados Unidos da América

GEE Gases de Efeito Estufa

GEPEA Grupo de Energia do Departamento de Engenharia de Energia e Automação Elétricas da Escola Politécnica da Universidade de São Paulo

IAP Índice de Qualidade das Águas Brutas para Fins de Abastecimento Público 
IBGE

ICMS

IDH

IGCC

IPAS

IPCC

IQA

IQC

IQR

IVA

LWC

MCTI

MDL

$\mathrm{MP}_{10}$

PAE

PEMC

PERH

PET

PIB

PIR
Instituto Brasileiro de Geografia e Estatística

Imposto sobre Operações relativas à Circulação de Mercadorias e sobre Prestações de Serviços de Transporte Interestadual e Intermunicipal e de Comunicação

Índice de Desenvolvimento Humano

Integrated Gasifier Systems/Combined Cycle

Indicador de Portabilidade das Águas Subterrâneas

Painel Intergovernamental de Mudanças Climáticas

Índice de Qualidade das Águas

Índice de Qualidade de Usinas de Compostagem

Índice de Qualidade de Aterro de Resíduos

Índice de Qualidade das Águas para Proteção da Vida Aquática e de

Comunidades Aquáticas

Light Weight Coated Paper (Papel fabricado com alta porcentagem de celulose)

Ministério da Ciência, Tecnologia e Inovação

Mecanismo de Desenvolvimento Limpo

Material Particulado inalável

Projeto Ambiental Estratégico

Política Estadual de Mudanças Climáticas de São Paulo

Plano Estadual de Recursos Hídricos

Planejamento Energético Tradicional

Produto Interno Bruto

Planejamento Integrado dos Recursos energéticos

PROCLIMA Programa de Monitoramento Climático em Tempo Real da Região 
Nordeste

PTS Partículas Totais em Suspensão

RELO Recursos Energéticos do Lado da Oferta

RMPS Região Metropolitana de São Paulo

SABESP Companhia de Saneamento Básico do Estado de São Paulo

SEADE Fundação Sistema Estadual de Análise de Dados

SMA Secretaria do Meio Ambiente

SPI Standardized Precipitation Index

SPP-Nemo Suzano Papel e Celulose S/A.

TAC Termo de Compromisso de Ajustamento de Conduta

TIR Taxa Interna de Retorno

TRS Total reduced sulphur (Enxofre reduzido total)

UGRHI Unidade de Gerenciamento de Recursos Hídricos

USP $\quad$ Universidade de São Paulo

WRI World Resources Institute

WBCSD GHG World Business Council for Sustainable Development Greenhouse Gas Protocol 


\section{LISTA DE SÍMBOLOS}

\begin{tabular}{|c|c|}
\hline Gg & Gigagrama ( $\times 10^{9}$ grama $)$ \\
\hline GJ & Gigajoule ( $\times 10^{9}$ Joule) \\
\hline GWh & Gigawatt por hora (x109 Watts) \\
\hline ha & Hectare \\
\hline kg/dia & Quilograma por dia \\
\hline $\mathrm{kg} / \mathrm{ADT}$ & Quilograma por tonelada seca ao ar (Air Dry tonne) \\
\hline $\mathrm{kg} / \mathrm{tsa}$ & Quilograma por tonelada seca ao ar \\
\hline $\mathbf{k m}^{2}$ & Quilômetro quadrado \\
\hline kV & Quilovolt \\
\hline kVA & Quilovolt Ampère \\
\hline kW & Quilowatt \\
\hline lb/MWh & Libras por Megawatt hora \\
\hline $\mathbf{m}^{2}$ & Metro quadrado \\
\hline $\mathbf{m}^{3}$ & Metros cúbicos \\
\hline $\mathrm{m}^{3} / \mathrm{h}$ & Metros cúbicos por hora \\
\hline $\mathrm{m}^{3} / \mathrm{s}$ & Metros cúbicos por segundo \\
\hline $\mathrm{mg} / \mathrm{MJ}$ & Miligrama por Megajoule \\
\hline $\mathrm{mg} / \mathrm{Nm}^{3}$ & Miligrama por Normal metro cúbico \\
\hline Mt & Megatonelada ( $\times 10^{6}$ tonelada) \\
\hline MW & Megawatt \\
\hline MWe & Megawatt elétrico \\
\hline MWh & Megawatt hora \\
\hline
\end{tabular}




$\begin{array}{ll}\text { MWth } & \text { Megawatt térmico } \\ \text { odt /dia } & \text { Oven dried ton (tonelada absolutamente seca) por dia } \\ \mathbf{t} / \mathbf{h} & \text { Tonelada por hora } \\ \mathbf{t} / \mathbf{M W h} & \text { Tonelada por Megawatt hora } \\ \mathbf{t s a} & \text { Tonelada seca ao ar } \\ \mathbf{u g} / \mathbf{c m}^{3} & \text { Micrograma por centímetro cúbico } \\ \mathbf{W} & \text { Watt }\end{array}$




\section{SUMÁRIO}

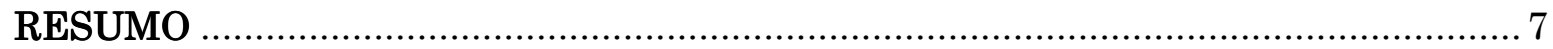

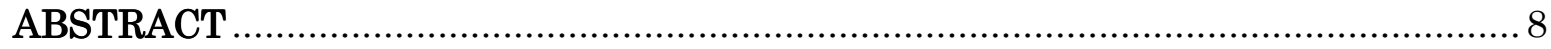

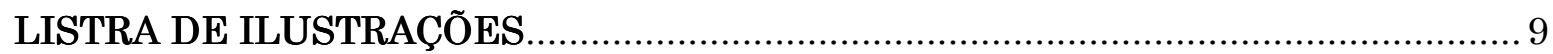

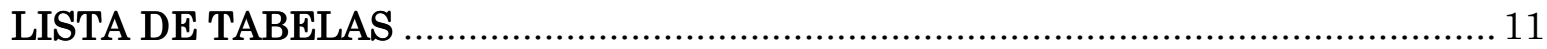

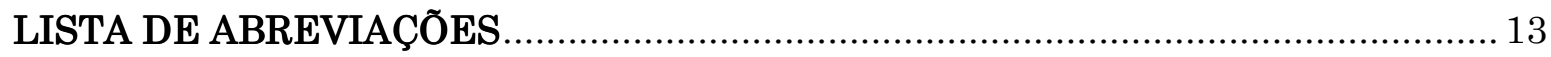

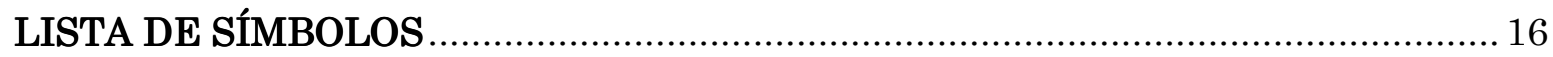

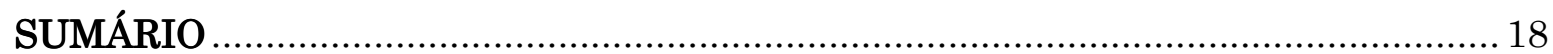

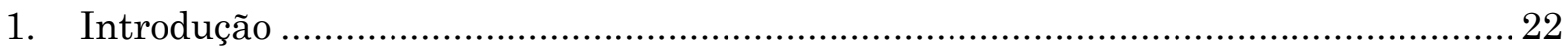

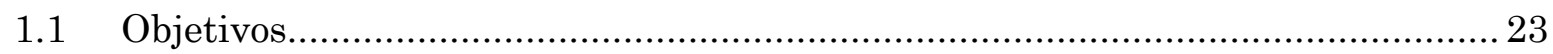

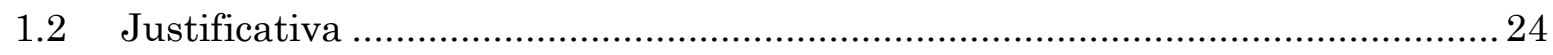

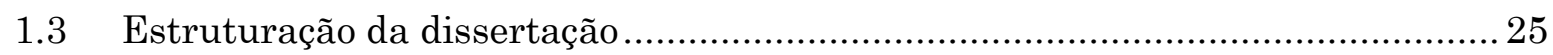

2. Caracterização de uma indústria de papel e celulose............................................26

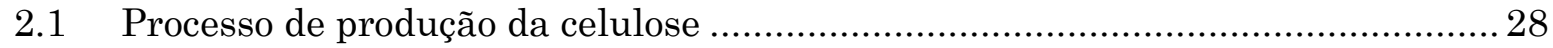

2.1.1 Plantio, colheita e preparação da madeira ................................................. 28

2.1.2 Cozimento, lavagem e depuração.............................................................29

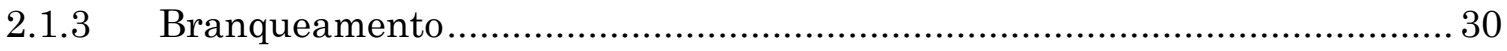

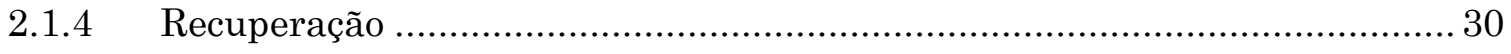

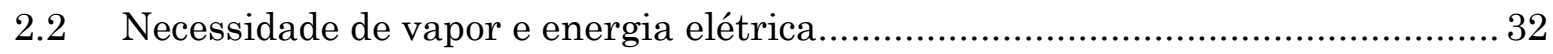

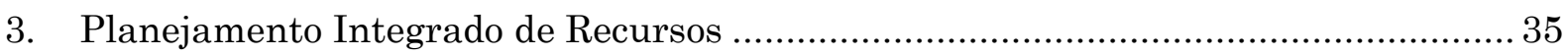

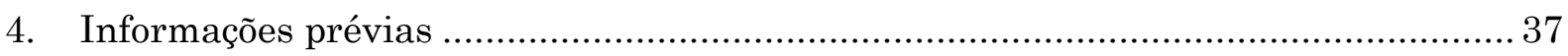

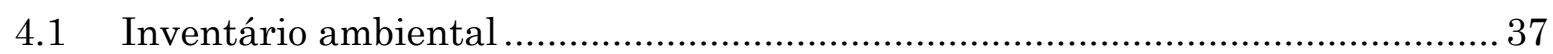

4.1.1 Inventário Nacional de Emissão de GEE .................................................... 37

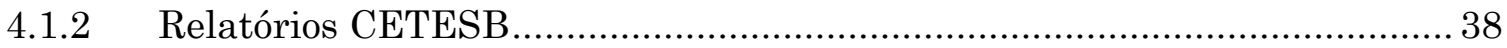


4.1.3 Inventário de Emissões Antrópicas de Gases de Efeito Estufa Diretos e

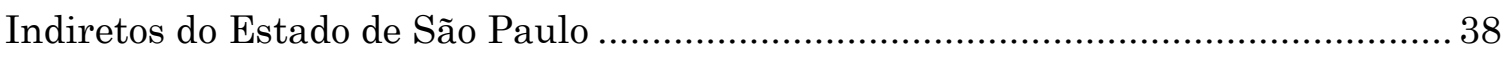

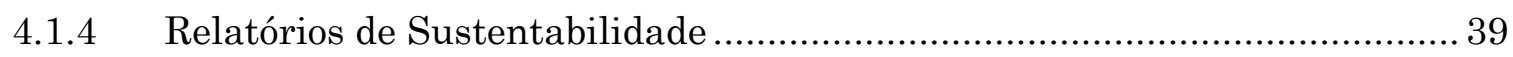

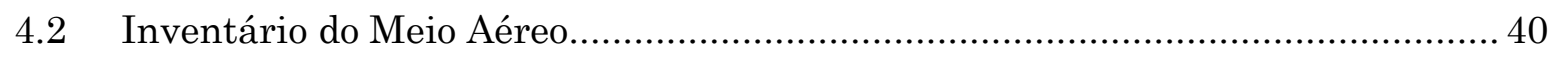

4.2.1 Emissões do setor industrial ........................................................... 41

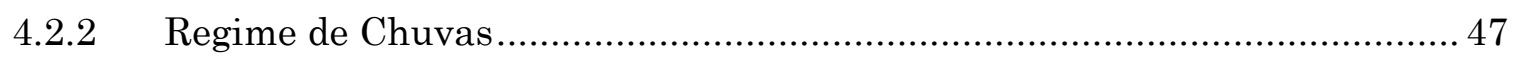

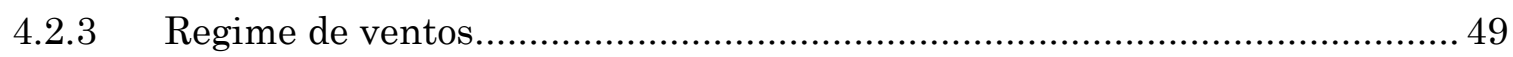

4.2.4 Regime de temperaturas ................................................................... 51

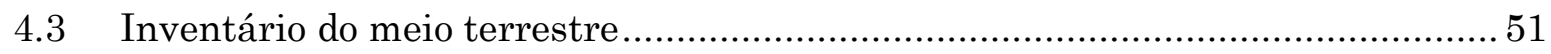

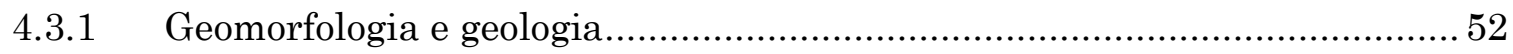

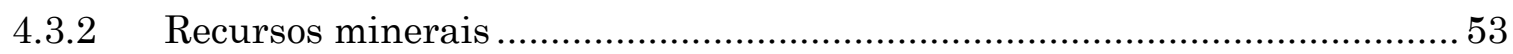

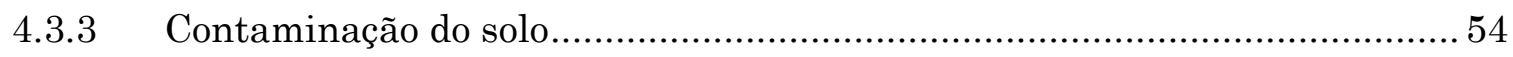

4.3.4 Gestão de resíduos sólidos urbanos ..................................................... 55

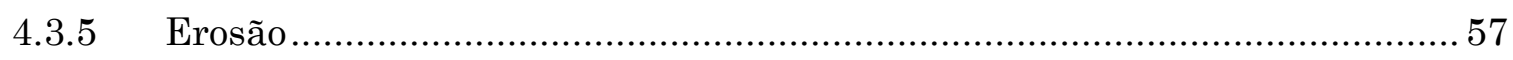

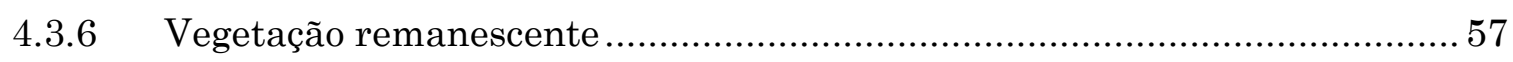

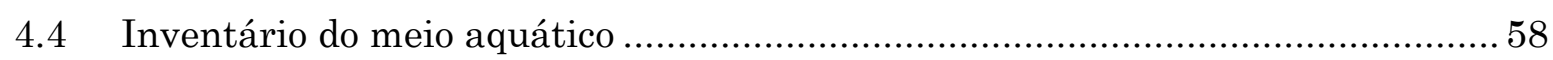

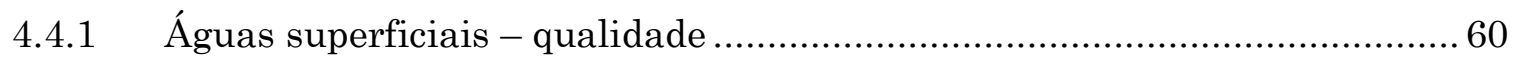

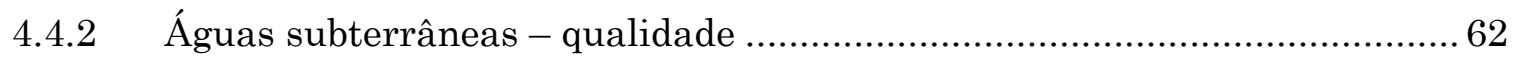

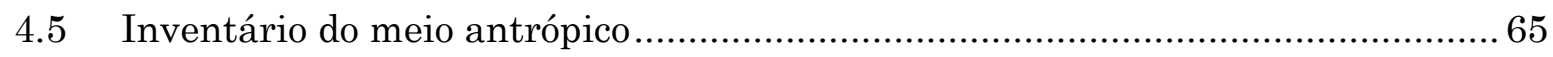

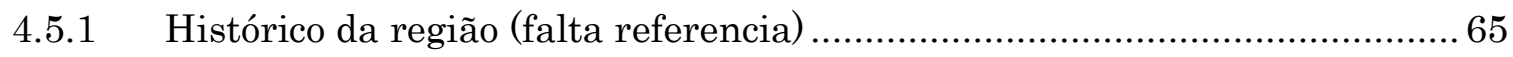

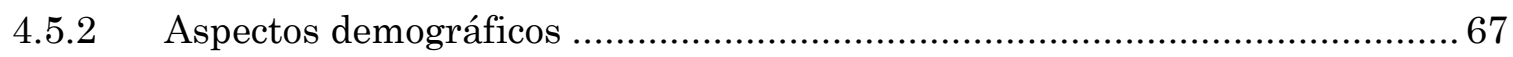

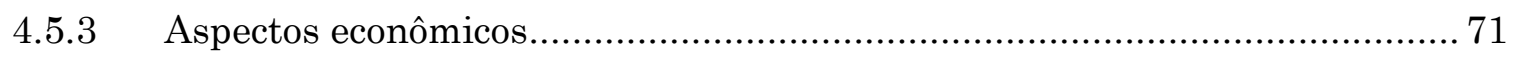

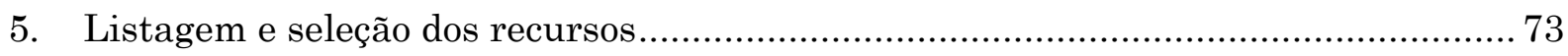

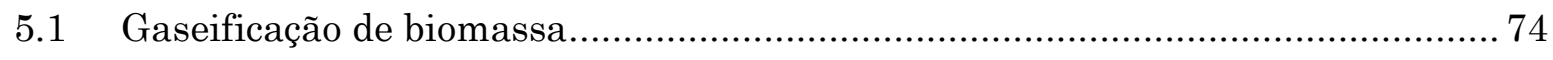

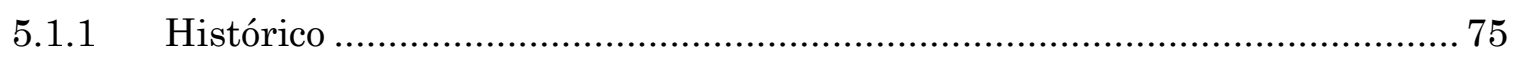

5.1.2 Aspectos termodinâmicos e químicos da gaseificação …............................ 77

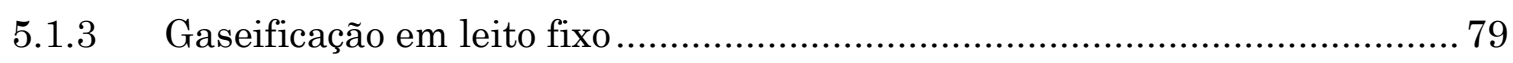


5.1.4 Gaseificação de leito fluidizado (Circulating fluidesed bed-CFB)

5.1.5 Gaseificação de leito de arraste (Entrained Flow) .................................... 83

5.1.6 Gaseificação do licor negro ............................................................... 84

5.1.7 Situação atual da gaseificação no mundo ............................................. 88

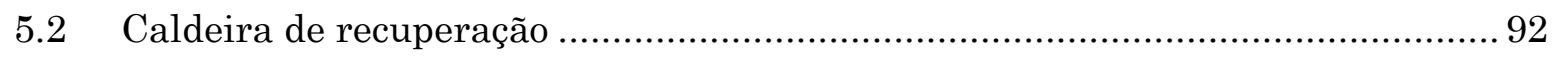

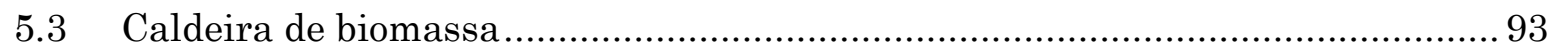

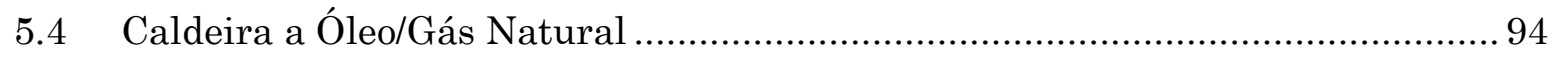

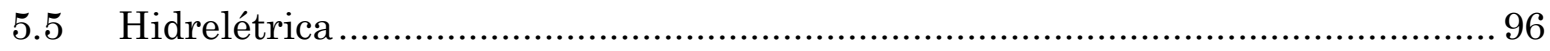

6. Cômputo e Valoração do Potencial Completo (CVPC) ................................................ 99

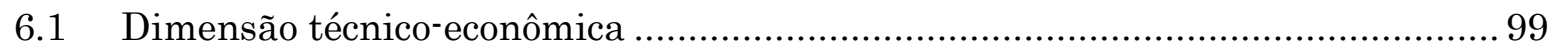

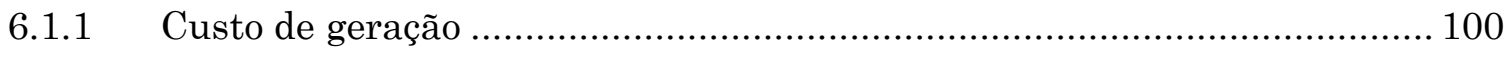

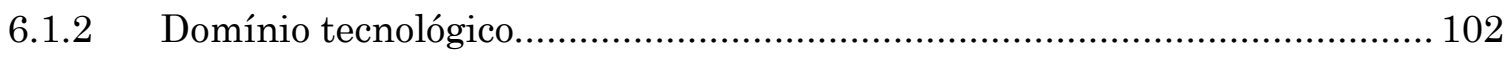

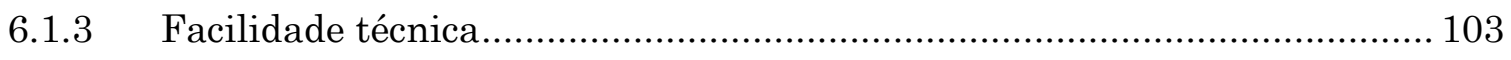

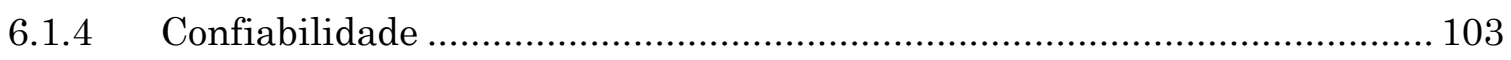

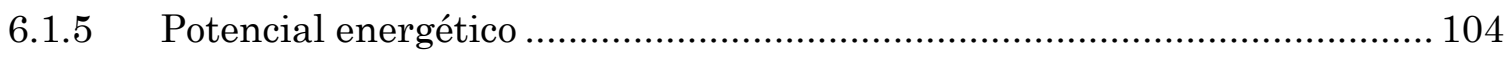

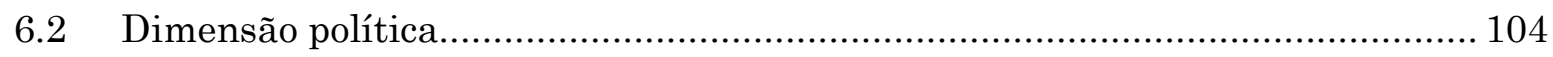

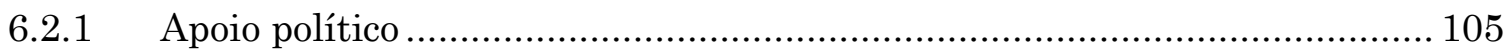

6.2.2 Posse de fonte energética e integração transfronteiriça ............................. 106

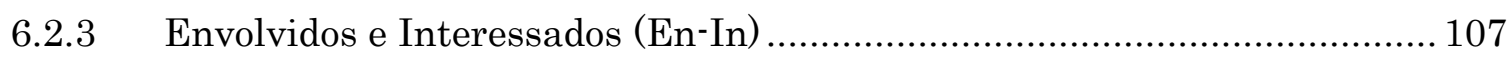

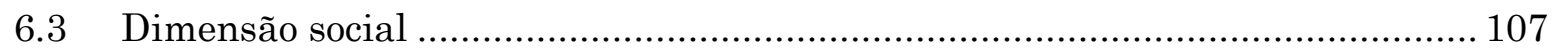

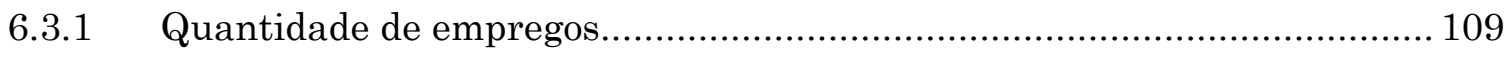

6.3.2 Impactos de desequilíbrio ambiental no meio social .............................. 109

6.3.3 Impacto humano decorrente da ocupação espacial de projetos.................. 110

6.3.4 Influência no desenvolvimento local ................................................ 111

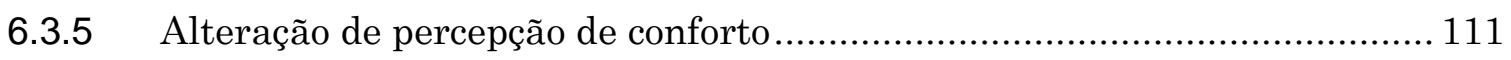

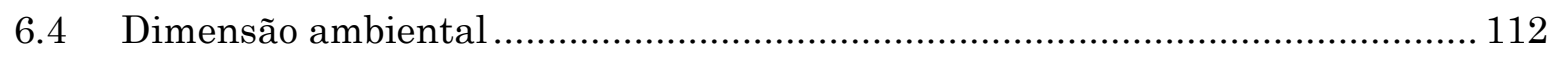




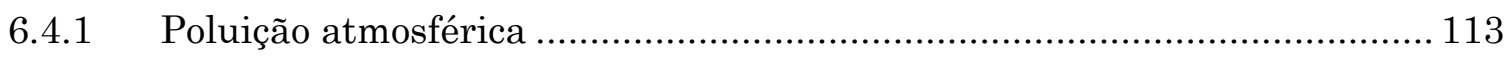

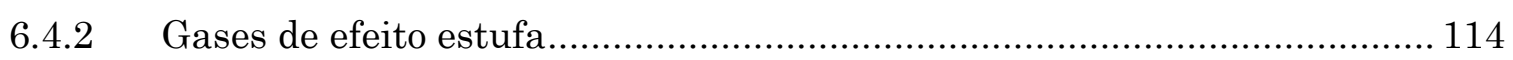

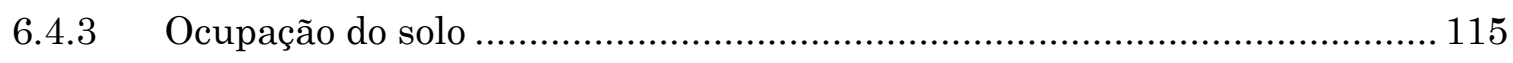

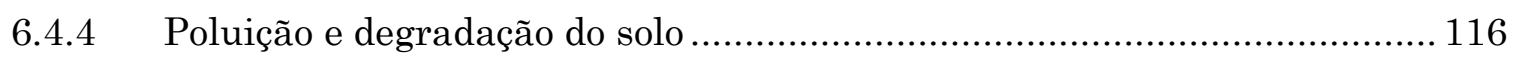

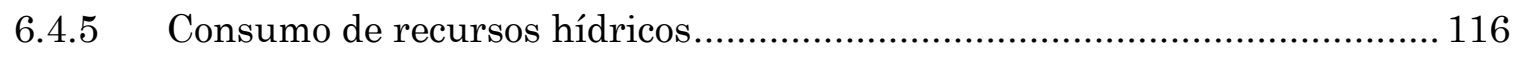

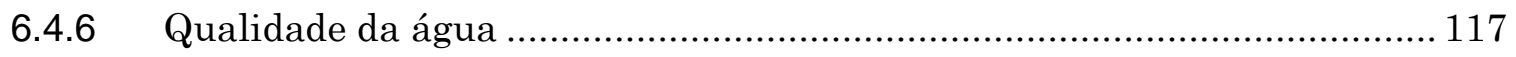

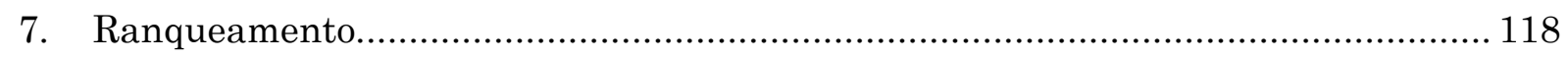

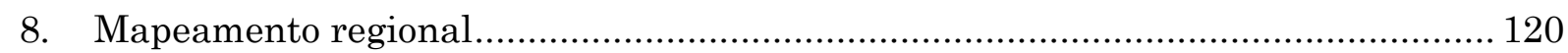

8.1 Caracterização do meio antrópico.............................................................. 120

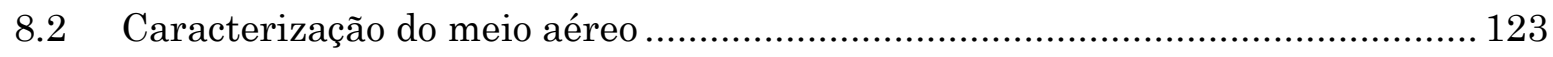

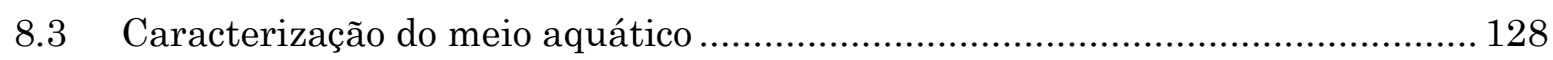

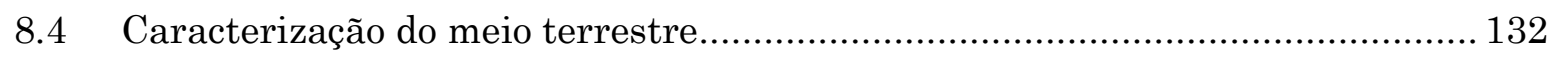

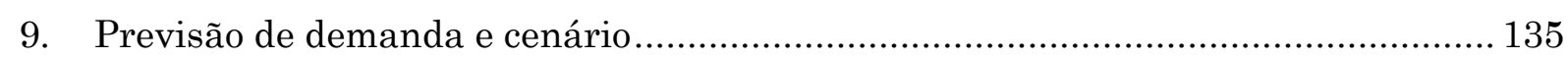

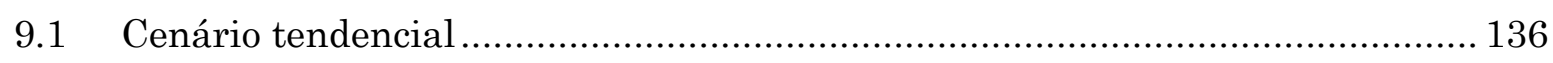

10. Plano Preferencial Integrado dos Recursos Energéticos ................................... 140

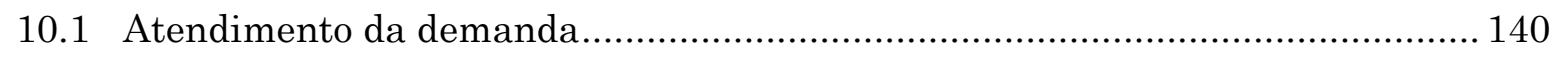

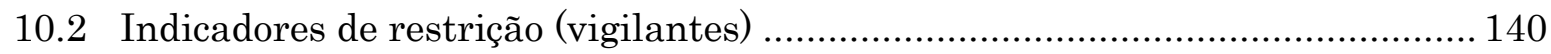

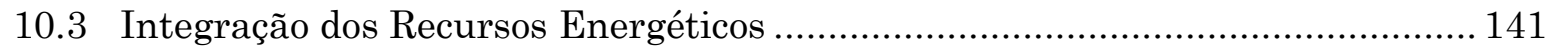

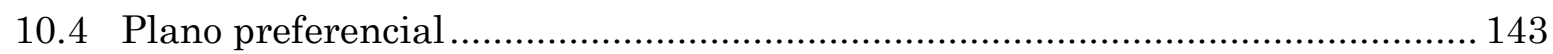

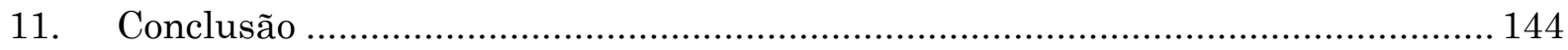

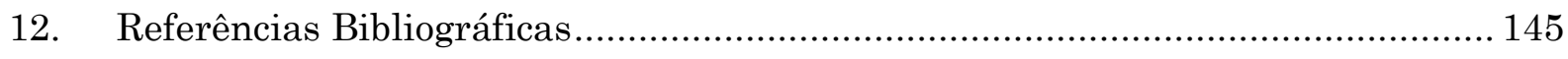

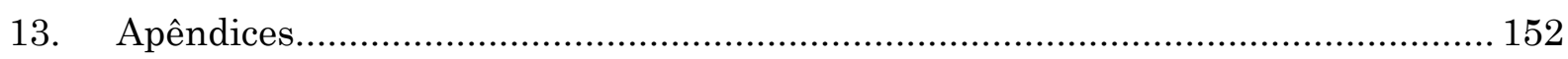




\section{Introdução}

Vivemos em um mundo onde o cuidado com o meio ambiente se torna cada vez mais importante. Ao mesmo tempo estamos vivenciando o forte crescimento econômico de países subdesenvolvidos que necessitam de recursos para sustentar esse crescimento. Um dos elementos indispensáveis para isso é a energia elétrica, vital para o dia a dia e para o desenvolvimento da sociedade moderna. Dependemos da energia para locomoção, utilização de equipamentos domésticos, produção industrial, entre outros usos. Essa dependência da sociedade moderna, associada à limitação dos recursos potenciais para geração, levou os profissionais e a comunidade científica a pensarem em como solucionar os problemas que poderão se apresentar no futuro em relação à falta de recursos energéticos. Desde então, começou-se a pensar em Planejamento Energético. Os modelos iniciais foram elaborados há algumas décadas, mas mostraram que ainda não respondem por completo às questões e aos desafios colocados perante a indústria energética.

Exemplos recentes no Brasil mostram como a falta de planejamento adequado pode impactar no crescimento de um país. Um dos setores que sofreu grande impacto foi o industrial. O crescimento econômico do país aumentava a cada ano, mas, em um determinado momento, a indústria deparou-se com uma estrutura de captação de energia que não comportava suas necessidades. O resultado foi a desaceleração do crescimento industrial. Sendo assim, o uso de ferramentas mais eficientes, que possam prever o processo de evolução da indústria energética e da demanda crescente em todos os países, tornou-se necessário. Associados a essa necessidade crescente por energia, problemas relacionados ao meio ambiente trazem reflexos negativos à sociedade, como o aumento de problemas de saúde pública. 
Outro problema é a crescente escassez dos recursos energéticos, além das novas limitações legais para a utilização de alguns recursos devido ao seu grau de poluição. O Planejamento Integrado dos Recursos energéticos (PIR) surgiu neste contexto e se originou do aprimoramento de modelos existentes, como o Planejamento Energético Tradicional (PET). O PIR procura atender os anseios de um desenvolvimento sustentável observando os impactos nas quatro dimensões que formam seus pilares: ambiental, social, político e técnico-econômico; todas elas são consideradas de igual relevância para o planejamento energético[6].

Diversos trabalhos sobre o PIR foram desenvolvidos no GEPEA/EPUSP e serviram de embasamento teórico para as discussões e proposições aqui realizadas( trabalhos estes que estão citadas na bibliografia). Este trabalho procura utilizar os conceitos do PIR em um ambiente corporativo, numa visão diferente em comparação aos trabalhos desenvolvidos anteriormente que aplicam o PIR como parte de uma politica pública de desenvolvimento sustentável .

Os planejamentos tradicionais não consideram as quatro dimensões com a mesma relevância, e em alguns casos uma ou mais dimensões não são consideradas. Nas indústrias principalmente um dos fatores principais são as econômicas. Neste trabalho iremos observar como seria o resultado se as quatro dimensões tivessem o mesmo peso.

\subsection{Objetivos}

O objetivo desta dissertação é aplicar os conceitos do PIR no meio corporativo. Como exemplo, o PIR será aplicado em uma indústria de papel e celulose, sobre a óptica dos Recursos Energéticos do Lado da Oferta (RELOs). As indústrias de papel 
e celulose correspondem a um segmento industrial com maior consumo de energia. Também é interessante o fato de que a principal matéria-prima é a madeira de eucalipto, um recurso renovável.

É também objetivo desta dissertação mostrar os conceitos de gaseificação de biomassa, seu estado da arte e potencial de uso numa indústria de papel e celulose.

\subsection{Justificativa}

O Planejamento Integrado dos Recursos energéticos (PIR) é uma ferramenta para tomada de decisão e tem uma estrutura metodológica de forma a conciliar o máximo de variáveis e parâmetros envolvidos em uma análise sistêmica, holística e racional dos recursos energéticos, trabalhando as diversas linhas de conhecimento de modo a contemplar diferentes enfoques e entendimentos para integração dos recursos e satisfação de demanda futura.

Tradicionalmente, o planejamento da indústria privada não trata dessas quatro dimensões de forma equilibrada, e, quando tratam, são atribuídos a elas pesos

diferenciados. É motivação desta dissertação mostrar o resultado da aplicação da metodologia do PIR em uma indústria.

As mudanças climáticas são uma preocupação de dimensão global que levou as Nações Unidas à criação do Quadro das Nações Unidas sobre Mudança do Clima, em que os países signatários se comprometeriam a estabilizar as emissões de Gases de Efeito Estufa (GEE) de maneira a mitigar a interferência antrópica no clima. Após a criação do Mecanismo de Desenvolvimento Limpo (MDL) pelo Protocolo de Kyoto, o tema também começou a ser discutido nas empresas. Neste contexto, o presente trabalho tem o intuito de mostrar um novo recurso (gaseificação de biomassa), 
alternativo às tecnologias tradicionais, para geração de energia elétrica.

\subsection{Estruturação da dissertação}

O trabalho foi dividido em 13 capítulos.

O primeiro capítulo explicita os objetivos desta dissertação de mestrado. O segundo capítulo apresenta uma caracterização da indústria de papel e celulose. Do capítulo três ao dez, é apresentada o desenvolvimento do trabalho baseado no PIRnaUSP visando a integração dos recursos energéticos para o desenvolvimento sustentável baseado em vários trabalhos já produzidos pelo GEPEA/EPUSP. Dentro do capítulo cinco, temos uma descrição da gaseificação de biomassa, bem como sua situação atual.

Ao capítulo 11 foi reservada a conclusão deste trabalho, e no capítulo 12, a biografia utilizada para a sua realização. 


\section{Caracterização de uma indústria de papel e celulose}

A maior parte da energia elétrica produzida no Brasil (mais de 90\% [9]) é proveniente de usinas hidroelétricas que estão sujeitas à sazonalidade hídrica, dependendo das condições climáticas. O racionamento ocorrido em 2001 mostrou como nosso sistema era frágil. Uma forma de diminuir essa fragilidade seria um sistema em que haja geração por outras fontes que o tornaria menos frágil. Dentro desse contexto, embora a geração por biomassa represente 0,07\% (em 2009 [9]), ela apresentou um crescimento em torno de $1.200 \%$ entre 2006 e 2009, conforme pode ser verificada na tabela abaixo (Tabela 1).

Tabela 1 - Produção por Origem em GWh

\begin{tabular}{lcccccc}
\hline \multicolumn{1}{c}{ Origem } & $\mathbf{2 0 0 5}$ & $\mathbf{2 0 0 6}$ & $\mathbf{2 0 0 7}$ & $\mathbf{2 0 0 8}$ & $\mathbf{2 0 0 9}$ & $\begin{array}{r}\text { Var } \\
\mathbf{2 0 6 / 0 9 )}\end{array}$ \\
\hline Hidrelétrica & $370.305,40$ & $382.247,60$ & $\mathbf{4 0 5 . 9 5 3 , 9 0}$ & $397.701,53$ & $414.542,72$ & 8.45 \\
Óleo Diesel & - & - & 72,7 & 678,98 & 11,95 & - \\
Óleo Comb. & 379,80 & 242,30 & 199,80 & $1.640,09$ & 387,01 & 59,72 \\
Gás Natural & $13.897,80$ & $13.175,90$ & $10.622,50$ & $24.640,13$ & $8.567,18$ & $-34,98$ \\
Carvão & $6.107,30$ & $6.686,70$ & $6.198,60$ & $6.269,38$ & $5.193,36$ & $-22,33$ \\
Eólicas & \multicolumn{7}{c}{237,70} & 559,00 & 556,81 & 711,54 & 199,34 \\
Biomassa & & 24,20 & 49,00 & 178,14 & 331,67 & $1.270,54$ \\
Nuclear & $9.855,50$ & $13.754,10$ & $12.349,90$ & $13.976,20$ & $12.956,98$ & $-5,80$ \\
Outros & - & - & $1.522,10$ & $3.161,31$ & $1.736,10$ & - \\
Total & $400.545,80$ & $416.368,50$ & $437.527,50$ & $448.802,57$ & $444.438,52$ & 6,74 \\
Emergencial & 398,7 & 18,3 & - & - & - & \\
\hline Total Geral & $400.944,50$ & $416.386,80$ & $437.527,50$ & $448.802,57$ & $444.438,52$ & 7,79 \\
\hline
\end{tabular}

Fonte: [9] [2011]

Entre os empreendimentos que utilizam biomassa, a geração por licor negro (ou lixívia, que é um subproduto dentro do processo de produção de celulose) corresponde à segunda posição em importância [10] conforme podemos verificar na tabela 2. 
Tabela 2 - Empreendimentos utilizando os combustíveis de classe biomassa

\begin{tabular}{cccc}
\hline Combustível & Quantidade & Potência (kW) & $\%$ \\
\hline Licor Negro & 14 & 1.228 .898 & 15,67 \\
Resíduos de Madeira & 36 & 302.627 & 3,86 \\
Capim Elefante & 1 & 1,7 & 0,02 \\
Biogás & 12 & 68.442 & 0,87 \\
Bagaço de Cana de Açucar & 318 & 6.197 .436 & 79 \\
Óleo de Palmiste & 1 & 1,64 & 0,02 \\
Carvão Vegetal & 3,00 & 25,20 & 0,32 \\
Casca de Arroz & 6 & 18.908 & 0,24 \\
\hline Total & 391 & 7.844 .851 & 100 \\
\hline
\end{tabular}

Fonte: [10] [2011/2012]

As indústrias de papel e celulose fazem parte de um segmento industrial crescente no Brasil. A principal matéria-prima das indústrias brasileiras é o eucalipto, diferentemente dos países do hemisfério norte, que utilizam o pinheiro.Essas indústrias geram 114 mil empregos diretos e 500 mil indiretos [12]. Podemos verificar na tabela 3 abaixo o crescimento do setor de papel e celulose no Brasil.

Tabela 3 - Desempenho do setor de papel e celulose (em mil toneladas) no Brasil

\begin{tabular}{lrrc}
\hline Celulose & $\mathbf{2 0 0 9}$ & $\mathbf{2 0 1 0}$ & $\mathbf{\%}$ \\
\hline Produção & 13.315 & 14.064 & 5,6 \\
Importação & 359 & 412 & 14,8 \\
Exportação & 8.229 & 8.375 & 1,8 \\
Consumo aparente & 5.445 & 6.101 & 12 \\
\hline & & & \\
\hline Papel & $\mathbf{2 0 0 9}$ & $\mathbf{2 0 1 0}$ & $\mathbf{\%}$ \\
\hline Produção & 9.428 & 9.792 & 3,9 \\
Importação & 1.085 & 1.502 & 38,4 \\
Exportação & 2.008 & 2.074 & 3,3 \\
Consumo aparente & 8.505 & 9.220 & 8,4 \\
\hline
\end{tabular}

Fonte: [40] [2010]

Na tabela 4 , é possível notar que o uso da lixívia para a produção de energia é crescente. Esse segmento tem grande potencial para se tornar autossuficiente em termos energéticos, produzindo todo o vapor e toda a 
eletricidade necessários ao processo. São bastante conhecidas as dificuldades do setor industrial quanto à garantia de disponibilidade de energia, devido às eventuais falhas e interrupções do sistema elétrico e à falta de confiabilidade da transmissão e distribuição de energia elétrica. Nesse cenário, a autossuficiência de cogeradores seria uma opção interessante para contribuir na oferta, permitindo à concessionária atender outros segmentos ainda não favorecidos pelo fornecimento de energia, evitando a construção de novas unidades de geração [7].

Tabela 4 - Matriz energética da Indústria Papel e Celulose (\%)

\begin{tabular}{lcccccccccc}
\hline Fontes & $\mathbf{2 0 0 0}$ & $\mathbf{2 0 0 1}$ & $\mathbf{2 0 0 2}$ & $\mathbf{2 0 0 3}$ & $\mathbf{2 0 0 4}$ & $\mathbf{2 0 0 5}$ & $\mathbf{2 0 0 6}$ & $\mathbf{2 0 0 7}$ & $\mathbf{2 0 0 8}$ & $\mathbf{2 0 0 9}$ \\
\hline Carvão Vapor & 1,3 & 1,4 & 1,2 & 1,2 & 1,2 & 0,7 & 1,0 & 0,9 & 0,9 & 0,9 \\
Gás Natural & 4,4 & 6,4 & 6,0 & 6,0 & 6,3 & 6,8 & 7,0 & 7,0 & 5,7 & 6,4 \\
Lenha & 16,9 & 16,7 & 14,8 & 14,6 & 15,6 & 15,3 & 15,6 & 15,2 & 15,3 & 15,2 \\
Lixivia & 36,9 & 37,0 & 37,7 & 41,8 & 43,1 & 43,5 & 44,9 & 45,5 & 45,5 & 45,5 \\
Óleo combustível & 15,8 & 13,2 & 13,4 & 10,6 & 8,7 & 8,2 & 5,4 & 4,9 & 5,6 & 5,2 \\
Eletricidade (rede) & 16,8 & 16,4 & 17,1 & 16,3 & 16,6 & 16,5 & 16,6 & 16,7 & 17,1 & 16,5 \\
Outras & 7,8 & 8,9 & 8,9 & 9,6 & 8,5 & 9,0 & 9,5 & 9,9 & 9,9 & 10,2 \\
\hline Total & 100,0 & 100,0 & 100,0 & 100,0 & 100,0 & 100,0 & 100,0 & 100,0 & 100,0 & 100,0 \\
\hline
\end{tabular}

Fonte: [11][2010]

\subsection{Processo de produção da celulose}

\subsubsection{Plantio, colheita e preparação da madeira}

O processo tem início com o plantio do eucalipto em viveiros, onde são usadas técnicas modernas disponíveis, como a microestaquia. As mudas produzidas são de uma variedade que tem maior resistência a pragas, alta produtividade de celulose e melhor adaptabilidade ao clima das respectivas regiões de plantio. [39]

Após o plantio e a formação das florestas atingirem a idade certa, é realizado o 
corte das árvores, geralmente utilizando equipamentos conhecidos pelo nome de harvester, que corta a árvore no pé, descasca e divide o tronco em toretes, deixando pronto para o transporte. Os toretes são transportados para a beira dos talhões de plantio e dali são transportados (por trem ou caminhão) para as fábricas. Nas fábricas, as madeiras são descascadas, quando já não estão, em tambores rotativos. Em seguida, elas são transportadas para os picadores, onde são transformadas em cavacos que são armazenados em Pátios de Madeira, aguardando o cozimento.[39]

\subsubsection{Cozimento, lavagem e depuração}

Os cavacos são transferidos por esteira até os digestores (contínuo e batelada), onde é realizado o processo de cozimento com soda líquida e adição de outros produtos químicos. Conhecido por processo Kraft, ele minimiza os danos às fibras de celulose de forma a preservar sua uniformidade e resistência. Durante o cozimento, as fibras de celulose são separadas da lignina e das resinas, quando então obtemos celulose não branqueada, de coloração marrom escura, com pequenos pedaços de madeira não cozida e impregnada de licor preto. A lavagem da celulose tem a finalidade de retirar os resíduos de licor preto, recuperando o máximo possível da soda usada no cozimento e a parcela de madeira que se transformou em líquido. A lavagem facilitará o posterior branqueamento, reduzindo o consumo de alvejantes e, principalmente, tornando o efluente mais limpo. Por outro lado, o licor preto resultante dessa lavagem é uma importante fonte de energia e será tratado posteriormente.

A depuração trata do peneiramento da pasta de celulose, com a finalidade de eliminar os não cozidos de madeira (palitos), facilitando o branqueamento e a 
limpeza do produto final. Também é possível realizar uma fase de pré-branqueamento, em que a celulose é submetida a um processo de deslignificação por oxigênio que, combinado com o processo Kraft, remove aproximadamente $95 \%$ da lignina.

\subsubsection{Branqueamento}

Nessa etapa, o intuito é retirar o percentual remanescente de lignina. Consiste numa série de torres de branqueamento, onde uma mistura de diferentes agentes branqueadores atuam na celulose. No processo convencional são utilizados cloro, dióxido de cloro e soda cáustica, ao passo que no processo de branqueamento ECF (Elemental Chlorine Free) não se utiliza cloro elementar. Ao final, a celulose branqueada é transferida para torres de armazenamento em forma líquida.

A partir deste ponto a celulose pode ser destinada diretamente às máquinas de papéis ou passar por secadoras, onde a celulose é secada, moldada, cortada e embalada, ficando pronta para o mercado.

\subsubsection{Recuperação}

Consiste em recuperar os reagentes químicos (99\%) e a energia utilizada no processo de fabricação de celulose, diminuindo, assim, os custos de produção. Ela passa basicamente por três processos:

- Evaporação;

- Recuperação da soda (caldeira de recuperação);

- Caustificação. 
$\mathrm{Na}$ evaporação, o objetivo é a concentração do licor negro obtido do sistema de lavagem. O licor negro é composto de aproximadamente $50 \%$ do cavaco utilizado no cozimento e reagentes químicos do cozimento. A evaporação pode ser direta ou indireta e de múltiplo efeito ou efeito único.

Na recuperação de soda, há três funções básicas:

- Recuperar reagentes inorgânicos;

- Recuperar energia;

- Diminuir poluição.

O licor negro concentrado passa, através de um aquecedor, para um tanque de mistura, no qual se adiciona o sulfato de sódio de reposição das perdas no processo. A partir daí, vai para o pulverizador da caldeira, localizado nas suas extremidades, e é injetado ar de combustão para a queima do material pulverizado. Os gases da combustão deixam o topo da caldeira a aproximadamente $980^{\circ} \mathrm{C}$. Os fundidos fluem através de bicas resfriadas com água e são dissolvidos num tanque com licor fraco de lavagem, resultando no licor verde. Com o calor resultante se produz vapor, que será utilizado na fábrica e, parte dele, na geração de energia elétrica. Os gases resultantes da combustão passam por precipitadores eletrostáticos ou lavadores Venturi-Scrubber para a retirada de partículas sólidas dispersas nos gases, eliminando a poluição do ambiente causada por elas.

Na caustificação, há a recuperação do licor branco, empregado no cozimento, e a recuperação da cal utilizada no próprio processo. O licor verde é clarificado para remover substâncias em suspensão (Dregs), que podem ser removidas por decantação ou através de filtros. Ao licor verde clarificado é adicionado cal para convertê-lo em hidróxido de sódio. Nesta reação, é formado um lodo contendo hidróxido de sódio e carbonato de sódio, que passam por um filtro ou decantador 
para separar o licor branco da lama de cal. Essa lama de cal é lavada para se retirar todo hidróxido de sódio antes de mandá-lo para a filtragem. O líquido que sai dessa lavagem é chamado de licor fraco. A lama de cal é lavada e filtrada num filtro rotativo de tambor a vácuo e depois mandada para o forno de cal. No forno de cal, que consiste em um cilindro (recoberto por material refratário) rotativo inclinado, a lama de cal passa pelas zonas de eliminação da umidade, de aquecimento e calcinação, formando óxido de cálcio que é armazenada em silos. Um resumo de todo o processo de produção de papel e celulose pode ser verificada na figura 1.

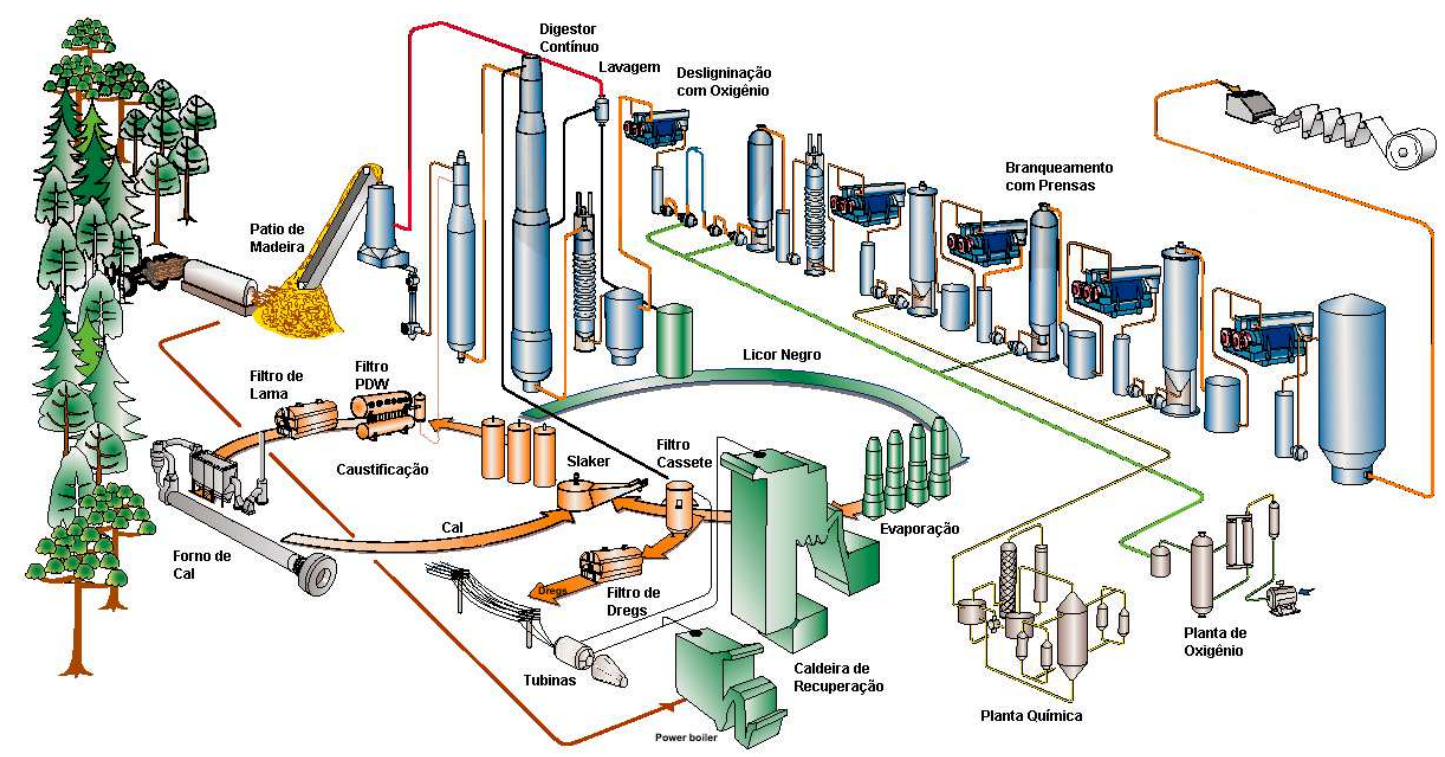

Figura 1 - Fluxograma do processo produtivo

\subsection{Necessidade de vapor e energia elétrica}

Outro aspecto importante a destacar é que numa indústria de papel e celulose é essencial a necessidade de vapor e eletricidade para a maioria das etapas de produção. Na figura 2, pode-se ter uma noção de como é o consumo nas várias etapas. 


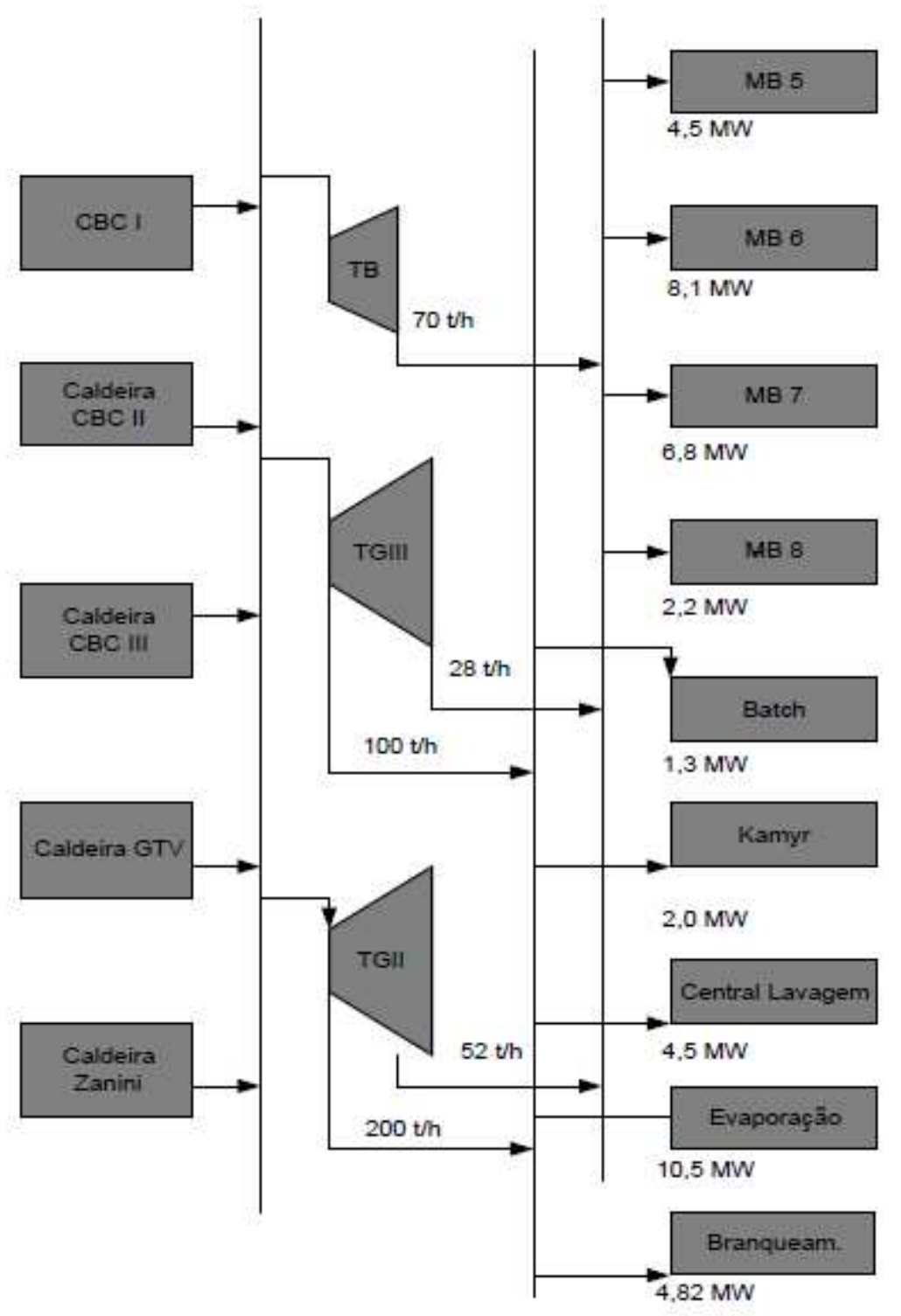

MB5,MB6,MB7 e MB8 sã̃o mạquinas de papel, TB, TG II e TG II são turtinas a vapor, Batch e Kanyr sỉo equupamentos unilizados no cozimento do eucalipto.

Figura 2 - Distribuição de vapor e energia

Fonte: [50]

O consumo de vapor é considerável devido à grande quantidade de equipamentos. Para satisfazer essas demandas, é essencial o uso de caldeiras nas fábricas.

O principal produto das caldeiras é o vapor. Ele é recolhido pelos coletores (figura 3) que o distribuem, através de turbo-geradores, para a geração de energia elétrica e 
também para a utilização no processo. O rendimento da turbina depende de qual tipo ela é e da carga que lhe é imposta.

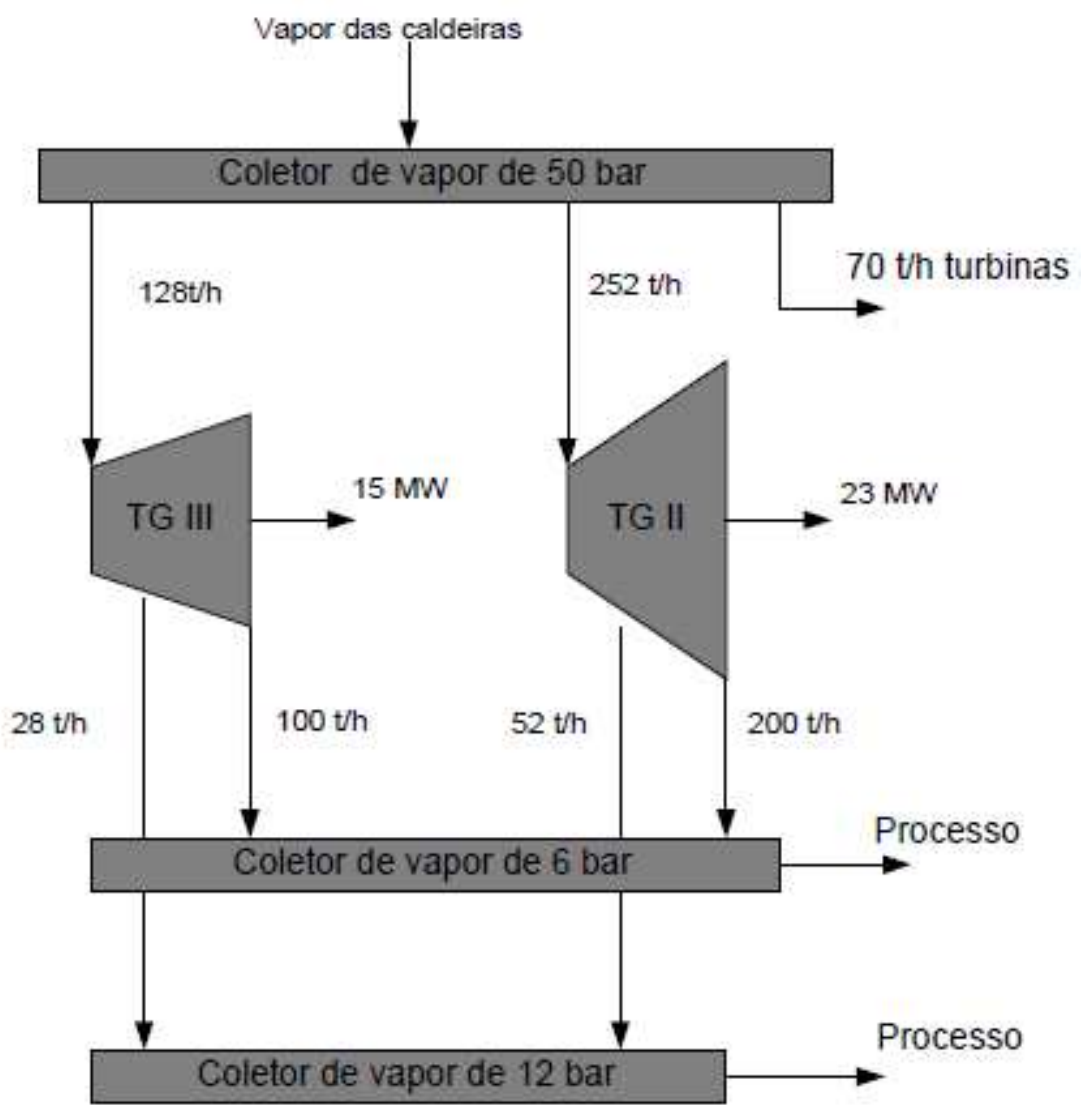

Figura 3 - Distribuição de vapor para o processo

Fonte: [50]

A geração de energia elétrica opera em separado da concessionária, de modo que parte da fábrica fica ligada aos turbo-geradores e outra parte, à concessionária. 


\section{Planejamento Integrado de Recursos}

O início dos estudos sobre o Planejamento Integrado dos Recursos energéticos no GEPEA deu-se com o desenvolvimento do projeto de pesquisa de doutorado "Planejamento Integrado dos Recursos - PIR - Para o Setor Elétrico (Pensando o Desenvolvimento Sustentável)", (UDAETA, 1997). Nesse trabalho foi desenvolvida toda a base teórica e filosófica para a formulação do processo do PIR. Além dos conceitos teóricos sobre o Planejamento Integrado dos Recursos, foram incorporadas ao estudo tanto a dimensão técnico-econômica tradicional quanto as dimensões ambiental, política e social. Posteriormente, foram realizados ensaios iniciais da aplicação dessas formulações na Região do Médio Paranapanema (Oficina de PIR Paranapanema, 2000). Diversos trabalhos sobre o PIR foram desenvolvidos no GEPEA/USP posteriormente, aperfeiçoando seu processo. A figura 4 mostra o diagrama esquemático do PIR que será aplicado nos próximos capítulos.

Não é objetivo desta dissertação detalhar a teoria do Planejamento Integrado de Recursos, assunto que foi amplamente discutido em diversos trabalhos desenvolvidos no GEPEA/USP. [5] e [6] e [55-61] 


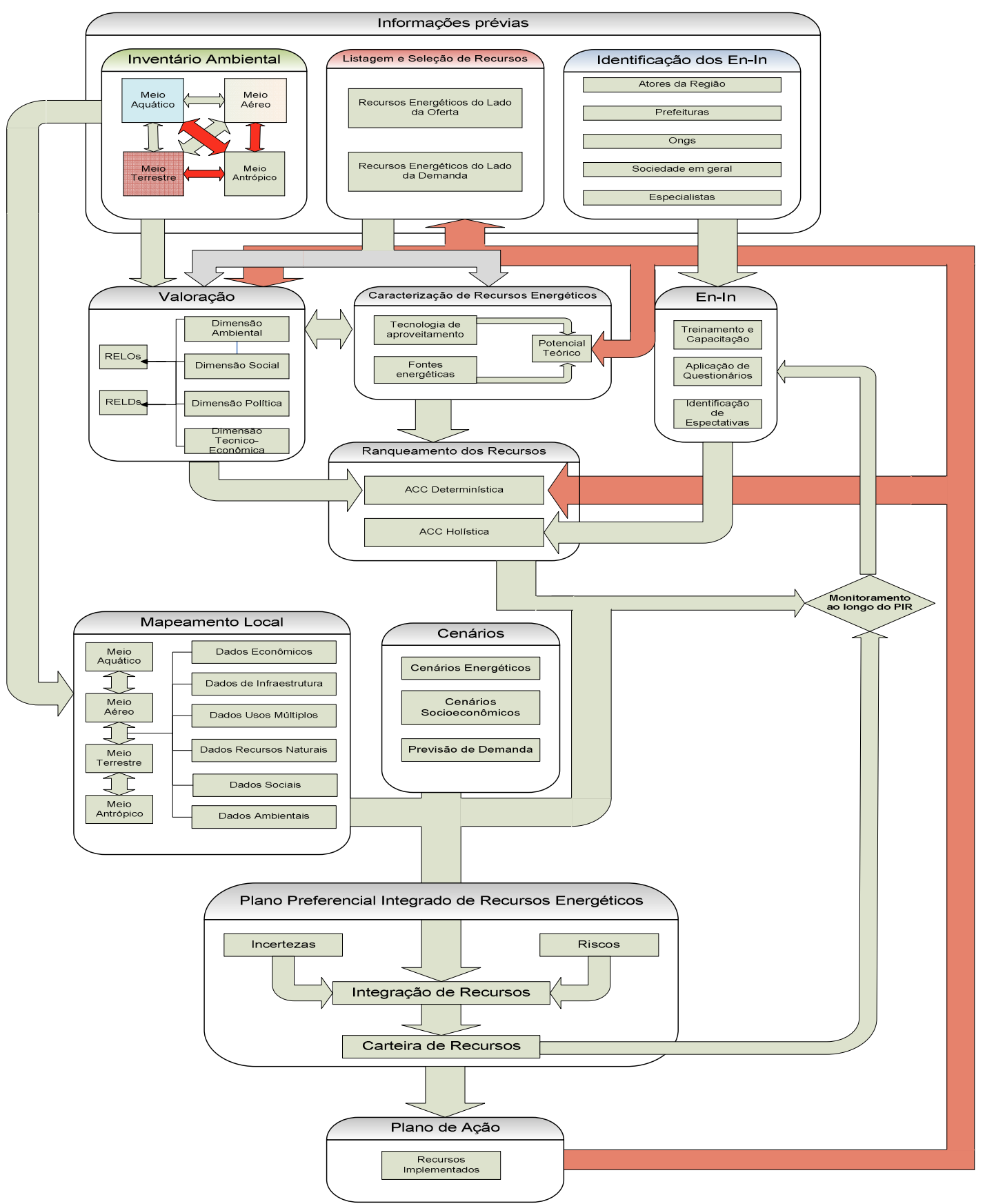

Figura 4 - Diagrama esquemático do PIR

Fonte: Udaeta et al, 2009 


\section{Informações prévias}

\subsection{Inventário ambiental}

Nesta etapa, as características da região em estudo devem ser descritas detalhadamente, apresentando dados referentes aos quatro meios correlacionados que definem o contexto ambiental local: antrópico, terrestre, aquático e aéreo. A localização da fábrica em estudo é no município de Suzano.

Vários inventários foram produzidos, podendo ser de maior ou menor abrangência, dentre os quais estão:

\subsubsection{Inventário Nacional de Emissão de GEE}

Para os gases de efeito estufa, há a publicação do "Inventário Nacional de Emissão de GEE". O Brasil, como país signatário da Convenção (IPCC), tem o compromisso de elaborar e atualizar periodicamente inventários nacionais de emissões antrópicas por fontes e das remoções por sumidouros de todos os gases de efeito estufa não controlados pelo Protocolo de Montreal. O país estabeleceu uma equipe sob coordenação do Ministério da Ciência e Tecnologia (MCT) que contribui com a comunicação nacional.

O Brasil publicou até agora dois inventários nacionais de emissões de GEE. O primeiro, em dezembro de 2004, referente às emissões de 1990 a 1994. Os dados específicos sobre resíduos sólidos e efluentes foram levantados pela CETESB através de monitoramentos locais. O segundo, em outubro de 2011, referente às emissões de 1990 a 2005. O compromisso assumido com as Nações Unidas era de apresentar as emissões até 2000, mas o Brasil decidiu avançar e agregar números 
dos cinco anos seguintes.

\subsubsection{Relatórios CETESB}

Em 2009, entrou em vigor a Lei 13.542, sancionada pelo Governo do Estado, em 8 de maio, que criou a "Nova CETESB". A agência ambiental paulista ganhou uma nova denominação e novas atribuições, principalmente no que diz respeito ao processo de licenciamento ambiental no estado. Com a mudança, ela ganhou fôlego institucional de uma verdadeira agência ambiental, eliminando o antigo modelo, já superado, de comando e controle, e adotando a agenda da gestão ambiental dentro da óptica da sustentabilidade.

A CETESB já realizou diversos levantamentos da situação estadual dos serviços de limpeza urbana e destinação final dos resíduos. Nesses relatórios, os dados foram pesquisados no estado de São Paulo, município por município. Os levantamentos foram separados basicamente em: águas superficiais, águas litorâneas, águas subterrâneas, ar e solo.

Com relação à qualidade do solo, a CETESB realiza inventários de resíduos sólidos domiciliares desde 1997. Essas informações reunidas compuseram o IQR Índice de Qualidade de Aterro de Resíduos e o IQC - Índice de Qualidade de Usinas de Compostagem.

\subsubsection{Inventário de Emissões Antrópicas de Gases de Efeito Estufa Diretos e Indiretos do Estado de São Paulo \\ O primeiro inventário das Emissões Antrópicas de Gases de Efeito Estufa} Diretos e Indiretos do Estado de São Paulo [45] é resultado de um projeto 
coordenado e realizado pelo PROCLIMA/CETESB/SMA, com apoio da Embaixada Britânica no Brasil. Ele contém as estimativas de emissões de Gases de Efeito Estufa ocorridas no estado de São Paulo entre 1990 e 2008, com base na metodologia aprovada pelo Painel Intergovernamental de Mudanças Climáticas (IPCC). As estimativas incluem os seis gases listados pelo Protocolo de Kyoto $\left(\mathrm{CO}_{2}, \mathrm{CH}_{4}, \mathrm{~N}_{2} \mathrm{O}\right.$, PFCs, HFCs, SF $_{6}$ ), os CFCs e os HCFCs (gases destruidores da camada de ozônio).

Esse inventário faz parte da Comunicação Estadual definida pela Política Estadual de Mudanças Climáticas de São Paulo - PEMC (Lei Estadual ํo 13.798/2009), que tem por objetivo geral estabelecer o compromisso do estado de São Paulo frente aos desafios das mudanças climáticas globais. A PEMC também determina uma meta de redução de $\mathrm{CO}_{2}$ da ordem de $20 \%$ (tendo como base o ano de 2005) a ser atingida no ano de 2020. Esse inventário será elaborado com periodicidade quinquenal, obedecendo à metodologia internacional definida pelo IPCC.

\subsubsection{Relatórios de Sustentabilidade}

Publicados desde 2003, reportam as ações da empresa nas dimensões econômica, social e ambiental. Quantificam as emissões de GEE associadas principalmente às atividades de controle operacional. Os indicadores contemplam os escopos de acordo com o Protocolo WRI/WBCSD GHG e, desde 2010, foram incluídas as emissões do SPP-Nemo. 


\subsection{Inventário do Meio Aéreo}

Pode-se caracterizar o meio aéreo em variáveis de dois grupos: os poluentes (como materiais particulados, fumaça, dióxido de enxofre etc.) e os gases de efeito estufa (como gás carbônico e gás metano).

Para os poluentes é possível utilizar dados gerados através da CETESB. Há relatórios relativos à qualidade do ar no estado de São Paulo ou as caracterizações das estações de monitoramento de fumaça.

O país tem atualmente o segundo inventário nacional de emissão de GEE, publicado em 2011, referente às emissões de 1990 a 2005. Os dados mostram que as emissões de GEE aumentaram cerca de $60 \%$ entre 1990 e 2005. Os gases considerados são o dióxido de carbono $\left(\mathrm{CO}_{2}\right)$, o metano $\left(\mathrm{CH}_{4}\right)$, o óxido nitroso $\left(\mathrm{N}_{2} \mathrm{O}\right)$, os hidrofluorcarbonos (HFC), os perfluorcarbonos (PFC) e o hexafluoreto de enxofre $\left(\mathrm{SF}_{6}\right)$. Alguns outros gases, como monóxido de carbono $(\mathrm{CO})$, óxidos de nitrogênio (NOx) e outros compostos orgânicos voláteis não metânicos (NMVOC), mesmo não sendo gases de efeito estufa direto possuem influência nas reações químicas que ocorrem na atmosfera.

A seguir, a Figura 5 apresenta os principais poluentes atmosféricos e suas características: 


\begin{tabular}{|c|c|c|c|}
\hline Poluente & Caracteristicas & Fontes Principais & $\begin{array}{c}\text { Efeitos Gerais ao Meio } \\
\text { Ambiente }\end{array}$ \\
\hline $\begin{array}{l}\text { Particulas Inaláveis }\left(\mathrm{MP}_{10}\right) \\
\text { e Fumaça }\end{array}$ & $\begin{array}{l}\text { Particulas de material sólido ou } \\
\text { liquido que ficam suspensas no } \\
\text { ar, na forma de poeira, neblina, } \\
\text { aerossol, fumaça, fuligem, etc. } \\
\text { Faixa de tamanho < } 10 \text { micra. }\end{array}$ & $\begin{array}{l}\text { Processos de combustão } \\
\text { (indústria e veiculos automo- } \\
\text { tores), aerossol secundário } \\
\text { (formado na atmosfera). }\end{array}$ & $\begin{array}{l}\text { Danos à vegetação, dete- } \\
\text { rioraçâo da visibilidade e } \\
\text { contaminação do solo. }\end{array}$ \\
\hline $\begin{array}{l}\text { Particulas Totais em } \\
\text { Suspensão (PIS) }\end{array}$ & $\begin{array}{l}\text { Particulas de material sólido ou } \\
\text { liquido que ficam suspensas no } \\
\text { ar, na forma de poeira, neblina, } \\
\text { aerossol, fumacca, fuligem, etc. } \\
\text { Faixa de tamanho < } 100 \text { micra. }\end{array}$ & $\begin{array}{l}\text { Processos industriais, veiculos } \\
\text { motorizados (exaustão), poeira } \\
\text { de rua ressuspensa, queima } \\
\text { de biomassa. Fontes naturais: } \\
\text { pólen, aerossol marinho e solo. }\end{array}$ & $\begin{array}{l}\text { Danos à vegetação, dete- } \\
\text { rioração da visibilidade e } \\
\text { contaminaçẫo do solo. }\end{array}$ \\
\hline Dióxido de Enxofre $\left(\mathrm{SO}_{2}\right)$ & $\begin{array}{l}\text { Gás incolor, com forte odor, } \\
\text { semelhante ao gás produzido na } \\
\text { queima de palitos de fósforos. } \\
\text { Pode ser transformado a } \mathrm{SO}_{{ }^{\prime}} \\
\text { que na presença de vapor } \\
\text { de água, passa rapidamente } \\
\text { a } \mathrm{H}_{2} \mathrm{SO}_{4} \text {. E um importante } \\
\text { precursor dos sulfatos, um dos } \\
\text { principais componentes das } \\
\text { particulas inaláveis. }\end{array}$ & $\begin{array}{l}\text { Processos que utilizam queima } \\
\text { de óleo combustivel, refinaria } \\
\text { de petróleo, veiculos a diesel, } \\
\text { produção de polpa e papel, } \\
\text { fertilizantes. }\end{array}$ & $\begin{array}{l}\text { Pode levar à formação de } \\
\text { chuva ácida, causar corrosão } \\
\text { aos materiais e danos à vege- } \\
\text { tação: follhas e colheitas. }\end{array}$ \\
\hline Dióxido de Nitrogênio $\left(\mathrm{NO}_{2}\right)$ & $\begin{array}{l}\text { Gás marrom avermelhado, com } \\
\text { odor forte e muito irritante. } \\
\text { Pode levar à formação de ácido } \\
\text { nítrico, nitratos (o qual contribui } \\
\text { para o aumento das particulas } \\
\text { inaláveis na atmosfera) e com- } \\
\text { postos orgânicos tóxicos. }\end{array}$ & $\begin{array}{l}\text { Processos de combustão } \\
\text { envolvendo veiculos automo- } \\
\text { tores, processos industriais, } \\
\text { usinas térmicas que utilizam } \\
\text { óleo ou gás, incinerações. }\end{array}$ & $\begin{array}{l}\text { Pode levar à formação de chu- } \\
\text { va ácida, danos à vegetação e } \\
\text { à colheita. }\end{array}$ \\
\hline Monóxido de Carbono (CO) & Gás incolor, inodoro e insípido. & $\begin{array}{l}\text { Combustão incompleta em } \\
\text { veiculos automotores. }\end{array}$ & \\
\hline Ozônio $\left(\mathrm{O}_{3}\right)$ & $\begin{array}{l}\text { Gás incolor, inodoro nas } \\
\text { concentrações ambientais e o } \\
\text { principal componente da névoa } \\
\text { fotoquímica. }\end{array}$ & $\begin{array}{l}\text { Não é emitido diretamente } \\
\text { para a atmosfera. É produ- } \\
\text { zido fotoquimicamente pela } \\
\text { radiaçâo solar sobre os óxidos } \\
\text { de nitrogênio e compostos } \\
\text { orgânicos voláteis. }\end{array}$ & $\begin{array}{l}\text { Danos às colheitas, à vegeta- } \\
\text { ção natural, plantaçōes agrico- } \\
\text { las; plantas ornamentais. }\end{array}$ \\
\hline
\end{tabular}

Figura 5 - Fontes e características dos principais poluentes na atmosfera

Fonte: [25]

\subsubsection{Emissões do setor industrial}

Através do inventário da CETESB (Tabela 5), é possível ter uma melhor compreensão da contribuição de cada um dos setores produtivos, com as emissões potenciais de $\mathrm{CO} 2$ de cada um deles, no que se refere à combustível fóssil, e do processo industrial utilizado. A indústria de papel e celulose em quinto lugar, atrás das indústrias petroquímicas, aço e ferro gusa, minerais não metálicos e químico. 
Tabela 5 - Emissões potenciais de $\mathrm{CO}_{2}$ provenientes da queima de combustível e da produção por tipologia industrial

\begin{tabular}{lcrr}
\hline \multicolumn{1}{c}{ Tipologia Indutrial } & $\begin{array}{c}\text { Emissão Potencial de CO2 (Mt/ano) } \\
\text { Queima de } \\
\text { combustivel } \\
\text { Fóssil }\end{array}$ & Produção & Total \\
\hline Aço e Ferro Gusa & 1,01 & 3,36 & 7,37 \\
Minerais não metálicos & 3,48 & 3,11 & 6,59 \\
Químico & 1,71 & 1,47 & 3,18 \\
Petroquímico & 9,17 & 0,21 & 9,38 \\
Papel e Celulose & 1,01 & 0,38 & 1,39 \\
Ferro ligas & 0,44 & 0,23 & 0,67 \\
Alimentício & 0,71 & & 0,071 \\
Textil & 0,26 & & 0,26 \\
Outros & 0,03 & & 0,03 \\
\hline
\end{tabular}

Obs: Mt/ano equivalente a 1.000.000 t/ano

Fonte: [24][2008]

\subsubsection{Emissões de veículos automotores}

O município de Suzano possui uma frota de 87.880 veículos, sendo 61.442 automóveis. Isso faz com que o município tenha a $41^{\text {a }}$ maior frota de veículos do estado de São Paulo [31].

Devido à falta de dados específicos sobre poluição atmosférica para o município de Suzano, foi realizada uma projeção (tabela 6) através de dados da CETESB (qualidade do ar no estado de São Paulo relativa ao ano de 2010) [25](figuras 6 e 7) e do Denatran (frota automotiva em 2011) [31]. 


\begin{tabular}{|c|c|c|c|c|c|}
\hline \multicolumn{2}{|c|}{ Categoria } & Combustivel & $\begin{array}{c}\text { Frota Circulante na } \\
\text { RMSP }\end{array}$ & $\begin{array}{l}\text { Idade Media } \\
\text { (anos) }\end{array}$ & $\begin{array}{c}\text { \% Frota RMSPI } \\
\text { Estado }\end{array}$ \\
\hline \multirow{3}{*}{\multicolumn{2}{|c|}{ Automóveis }} & Gasolina & 2.633 .899 & 12 & 57 \\
\hline & & Etanol & 222.986 & 22 & 44 \\
\hline & & Flex & 1.869 .098 & 3 & 54 \\
\hline \multirow{4}{*}{\multicolumn{2}{|c|}{ Comerciais leves }} & Gasolina & 375.181 & 10 & 58 \\
\hline & & Etanol & 20.801 & 22 & 40 \\
\hline & & Flex & 189.477 & 3 & 44 \\
\hline & & Diesel & 129.224 & 7 & 46 \\
\hline \multirow{3}{*}{ Caminhōes } & Leves & \multirow{3}{*}{ Diesel } & 64.805 & 14 & 41 \\
\hline & Médios & & 31.307 & 15 & 42 \\
\hline & Pesados & & 71.555 & 8 & 43 \\
\hline \multirow{2}{*}{ Onibus } & Urbanos & \multirow{2}{*}{ Diesel } & 46.363 & 10 & 54 \\
\hline & Rodoviários & & 5.151 & 10 & 54 \\
\hline \multirow{2}{*}{\multicolumn{2}{|c|}{ Motocicletas }} & Gasolina & 745.596 & 6 & 34 \\
\hline & & Flex & 32.830 & 1 & 23 \\
\hline \multicolumn{3}{|c|}{ TOTAL } & 6.438 .273 & 10 & 50 \\
\hline
\end{tabular}

Figura 6 - Estimativa da frota de veículos da RMPS (região metropolitana de SP) em 2010 Fonte: [25] 


\begin{tabular}{|c|c|c|c|c|c|c|c|c|}
\hline \multirow{2}{*}{\multicolumn{3}{|c|}{ Categoria }} & \multirow{3}{*}{$\begin{array}{c}\text { Combustivel } \\
\text { Gasolina }\end{array}$} & \multicolumn{4}{|c|}{ Emissão (1000 t/ano) } & \multirow[b]{2}{*}{$\mathrm{SO}_{\mathrm{x}}$} \\
\hline & & & & \multirow{2}{*}{$\begin{array}{c}\mathrm{CO} \\
74,92\end{array}$} & \multirow{2}{*}{$\begin{array}{l}\text { HC } \\
5,12\end{array}$} & \multirow{2}{*}{$\begin{array}{l}\mathrm{NO}_{\mathrm{x}} \\
4,82\end{array}$} & \multirow{2}{*}{ MP } & \\
\hline \multirow{17}{*}{ 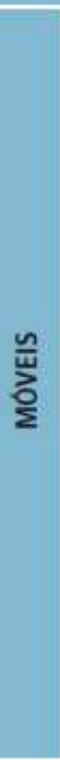 } & \multirow{3}{*}{\multicolumn{2}{|c|}{ Automóveis }} & & & & & & \\
\hline & & & Etanol & 13,81 & 1,46 & 1,16 & nd & \\
\hline & & & Flex & 21,32 & 2,41 & 2,07 & nd & \\
\hline & \multicolumn{2}{|c|}{ Evaporativa ${ }^{1}$} & - & - & 9,05 & - & - & \\
\hline & \multirow{4}{*}{\multicolumn{2}{|c|}{ Comerciais Leves }} & Gasolina & 8,71 & 0,62 & 0,60 & nd & \\
\hline & & & Etanol & 1,25 & 0,13 & 0,11 & nd & \\
\hline & & & Flex & 0,97 & 0,11 & 0,09 & nd & \\
\hline & & & Diesel & 0,46 & 0,12 & 2,39 & 0,06 & \\
\hline & \multicolumn{2}{|c|}{ Evaporativa ${ }^{1}$} & - & - & 0,99 & - & - & \\
\hline & \multirow{3}{*}{ Caminhões } & Leves & & 0,26 & 0,08 & 1,49 & 0,06 & \\
\hline & & Médios & Diesel & 1,30 & 0,41 & 7,36 & 0,28 & \\
\hline & & Pesados & & 4,69 & 1,19 & 26,96 & 0,69 & \\
\hline & \multirow{2}{*}{ Onibus } & Urbanos & Diesel & 3,00 & 0,81 & 16,80 & 0,52 & \\
\hline & & Rodoviários & & 0,70 & 0,19 & 3,98 & 0,12 & \\
\hline & \multirow{2}{*}{\multicolumn{2}{|c|}{ Motocicletas }} & Gasolina & 24,99 & 4,57 & 0,97 & nd & \\
\hline & & & Flex & 0,06 & 0,01 & 0,01 & nd & \\
\hline & \multicolumn{3}{|c|}{ Total Emissão Veicular } & 156,43 & 27,27 & 68,82 & 1,74 & $3,11^{12}$ \\
\hline \multirow{4}{*}{$\underset{x}{\mathbb{x}}$} & \multirow{2}{*}{\multicolumn{3}{|c|}{$\begin{array}{l}\text { Operação de Processo Industrial (2008) } \\
\text { (Número de indústrias inventariadas) }\end{array}$}} & $4,18^{3}$ & $4,7^{3}$ & $15,43^{3}$ & $3,06^{3}$ & $5,59^{3}$ \\
\hline & & & & $(62)$ & (121) & (161) & (198) & (146) \\
\hline & \multicolumn{3}{|c|}{$\begin{array}{l}\text { Base de combustivel liquido (2009) } \\
\text { (18 empreendimentos) }\end{array}$} & - & $3,40^{4}$ & - & - & - \\
\hline & \multicolumn{3}{|c|}{ TOTAL GERAL } & 160,61 & 35,37 & 84,25 & 4,80 & 8,70 \\
\hline
\end{tabular}

1 - Cálculo da emissao de HC evaporado de veiculos equipados com motor do cido otto (etanol, gasolina ou flex-fuel), exceto motocidetas. Nao está considerada a emissa gerada no abastecimento.

2- Metodologia top-down, baseada no consumo global de combustivel. Adotou-se que todo o enxofre contido no combustivel foi transformado em $\mathrm{SO}_{2}$, que o diesel $\$ 50$ contèm 50 ppm de enxofre, que o $\$ 500$ contèm 500 ppm de enxofre e que houve consumo de diesel interior (1800 ppm de enxofre) nas regioes. Adotou-se 350 ppm de enxofre para a gasolina C.

3-Ano de referência do inventário: 2008.

4 - Ano de referência do levantamento: 2009. Os empreendimentos participantes deste levantamento foram selecionados utilizando a metodologia top-down, baseado nas informaçōes da Agencia Nacional de Petroleo (ANP) sobre entregas de combustiveis do ano de 2009 Obs: Ano de referência do inventário de fontes móveis. 2010. nd: ná disponivel.

Figura 7 - Estimativas de emissão das fontes de poluição do ar na RMSP

Fonte: [25][2010]

Através das figuras 6 e 7, obteve-se a emissão de GEE por veículo. Multiplicando-se esses dados pela quantidade de veículos em Suzano, obtém-se a tabela 6 . 
Tabela 6 - Estimativas de emissão (ton/ano) das fontes de poluição do ar em Suzano

\begin{tabular}{|c|c|c|c|c|c|c|}
\hline Automóveis & $\mathrm{CO}$ & $\mathrm{HC}$ & NOx & MP & \multicolumn{2}{|c|}{ sox } \\
\hline Gasolina & 974,03 & 66,56 & \multicolumn{2}{|c|}{62,66} & 0 & 0 \\
\hline Etanol & 179,54 & 18,98 & \multicolumn{2}{|l|}{15,08} & 0 & 0 \\
\hline Flex & 277,18 & 31,33 & \multicolumn{2}{|l|}{26,91} & 0 & 0 \\
\hline Comerciais & $\mathrm{CO}$ & $\mathrm{HC}$ & NOx & MP & \multicolumn{2}{|c|}{ sox } \\
\hline Gasolina & 103,6 & 7,37 & 7,14 & & 0 & 0 \\
\hline Etanol & 14,87 & 1,55 & 1,31 & & 0 & 0 \\
\hline Flex & 11,54 & 1,31 & 1,07 & & 0 & 0 \\
\hline Diesel & 5,47 & 1,43 & 28,43 & & 0,71 & 0 \\
\hline
\end{tabular}

\begin{tabular}{lrrrrrr}
\hline Caminhões Diesel & CO & \multicolumn{1}{c}{ HC } & \multicolumn{2}{c}{ NOx } & MP & SOX \\
\hline Leves & 5,31 & 1,63 & 30,45 & 1,23 & 0 \\
Médios & 26,56 & 8,38 & 150,39 & 5,72 & 0 \\
Pesados & 95,83 & 24,32 & 550,88 & 14,1 & 0 \\
\hline
\end{tabular}

\begin{tabular}{|c|c|c|c|c|c|}
\hline Ônibus Diesel & $\mathrm{CO}$ & $\mathrm{HC}$ & NOx & MP & sox \\
\hline Urbanos & 63,01 & 17,01 & 352,87 & 10,92 & 0 \\
\hline Rodoviários & 14,7 & 3,99 & 83,6 & 2,52 & 0 \\
\hline
\end{tabular}

\begin{tabular}{|c|c|c|c|c|c|c|}
\hline Motocicletas & $\mathrm{CO}$ & $\mathrm{HC}$ & NOx & MP & \multicolumn{2}{|c|}{ sox } \\
\hline Gasolina & 412,75 & 75,48 & 16,02 & & 0 & 0 \\
\hline Flex & 0,99 & 0,17 & 0,17 & & 0 & 0 \\
\hline
\end{tabular}

Fonte: Elaboração própria [2011]

Além desses gases, merece destaque um gás poluente secundário, o ozônio.

Por seu caráter altamente oxidante, o ozônio é capaz de modificar o equilíbrio ambiental de ecossistemas e alterar a bioquímica das plantas, podendo, inclusive, afetar a produção agrícola, reduzindo a safra de forma discreta, mas economicamente significativa. Pela figura 8 podemos ter uma ideia da situação na UGRHI 6.

Ele possui uma distribuição distinta ao longo dos meses quando comparado aos poluentes primários, uma vez que é formado na atmosfera por reações fotoquímicas que dependem da radiação solar, dentre outros fatores. Dessa forma, o ozônio ocorre com maior frequência no período compreendido entre setembro e 
março, meses com maior incidência de radiação solar no topo da atmosfera.

O NOx é precursor do ozônio, poluente que vem apresentando os piores índices de qualidade do ar nos últimos anos na RMSP, sendo que a maior parcela de NOx é oriunda da poluição automotiva.

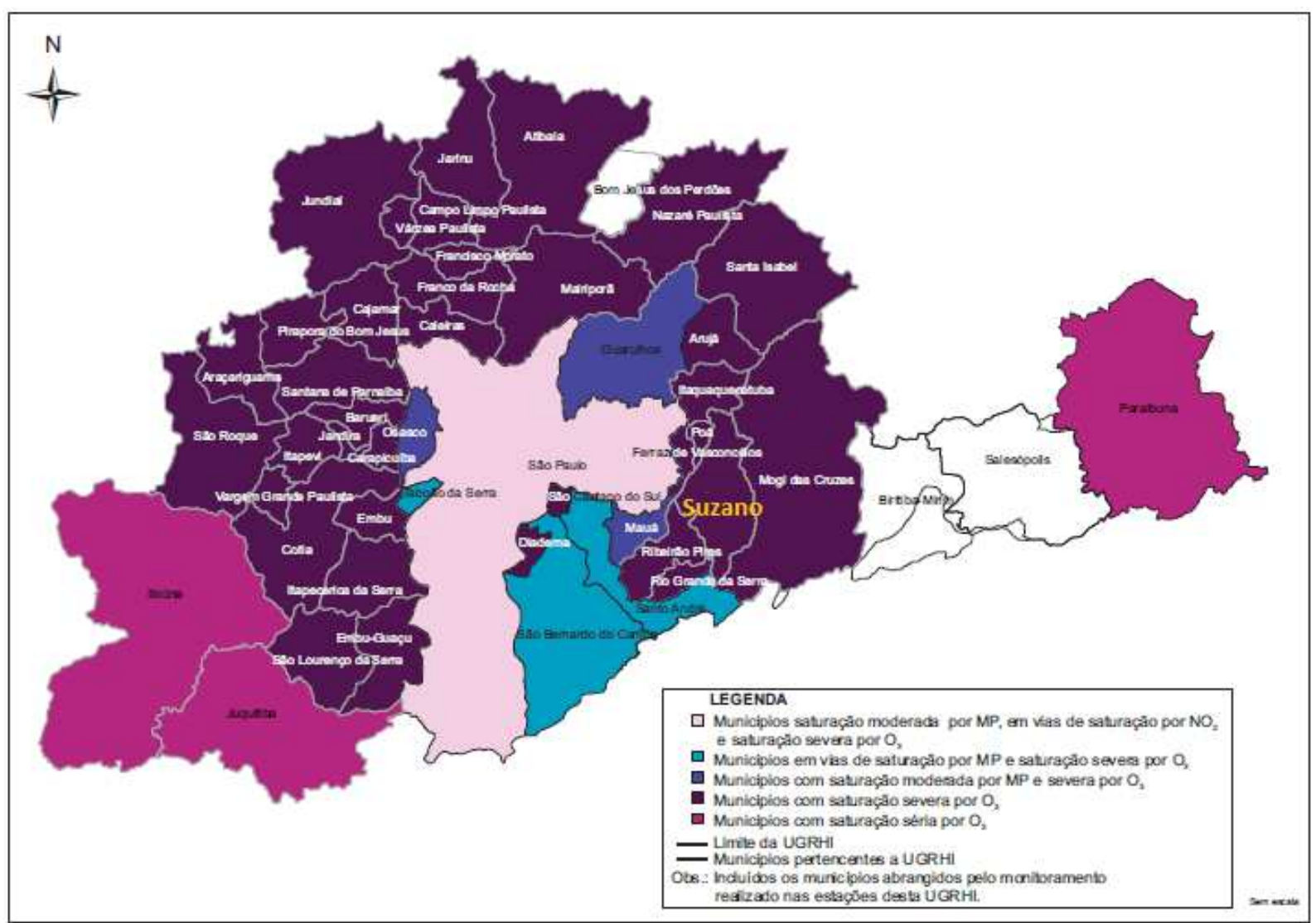

Figura 8 - Classificação de saturação e graduação de severidade para os municípios da UGRHI 6 Fonte: [25][2010]

Podemos verificar pela tabela 7 que houve uma redução de poluentes emitidos pelo setor entre 2009 e 2010. 
Tabela 7 - Emissão de GEE no setor de papel e celulose

\begin{tabular}{|c|c|c|}
\hline Emissões (t) & 2009 & 2010 \\
\hline NOx & $12.327,30$ & $16.252,10$ \\
\hline SOx & $15.377,10$ & $9.102,10$ \\
\hline Metano & 0,2 & 0,2 \\
\hline Poluentes orgânicos persistentes(POP) & - & - \\
\hline Composto orgânicos voláteis (VOC) & 0,4 & 0,5 \\
\hline Emissões de chaminé e fugitivas & - & - \\
\hline Poluentes atmosféricos perigosos (HAP) & - & - \\
\hline Material particulado (PM) & $23.296,90$ & $14.650,90$ \\
\hline $\begin{array}{l}\text { Outras categorias-padrão de emissões atmosféricas } \\
\text { identificadas em regulamentos }\end{array}$ & 99,8 & 11,9 \\
\hline Total & $51.101,74$ & $40.117,64$ \\
\hline
\end{tabular}

Fonte: [40][2010]

\subsubsection{Regime de Chuvas}

McKee et al. (1993) desenvolveram um índice que quantifica o déficit ou o excesso de precipitação para diferentes escalas de tempo. Essa versatilidade permite ao Standardized Precipitation Index (SPI) monitorar o fornecimento de água em pequenas escalas (interesse agrícola), assim como monitorar tal fornecimento em longas escalas de tempo (interesse hidrológico).

O SPI é baseado em um banco histórico de dados de chuva (30 anos no mínimo). Na tabela 8 é possível verificar a relação entre o SPI e a categoria de seca. 
Tabela 8 - Relação entre SPI e a categoria de seca

\begin{tabular}{|c|c|}
\hline Valor de SPI & Categoria \\
\hline 2 e acima & $\begin{array}{c}\text { Extremamente } \\
\text { úmido }\end{array}$ \\
\hline 1,5 a 1,99 & Muito úmido \\
\hline 1,0 a 1,49 & $\begin{array}{c}\text { Moderadamente } \\
\text { úmido }\end{array}$ \\
\hline 0,99 a $-0,99$ & $\begin{array}{l}\text { Próximo à } \\
\text { normal }\end{array}$ \\
\hline$-1,00 a-1,49$ & $\begin{array}{c}\text { Moderadamente } \\
\text { seco }\end{array}$ \\
\hline$-1,5 a-1,99$ & $\begin{array}{c}\text { Severamente } \\
\text { seco }\end{array}$ \\
\hline$-2,00$ e abaixo & $\begin{array}{c}\text { Extremamente } \\
\text { seco }\end{array}$ \\
\hline
\end{tabular}

Fonte: [32]

A Figura 9 mostra o total de precipitação de 12 meses consecutivos comparado com índices normais e com a distribuição normal de uma média histórica de 30 anos.

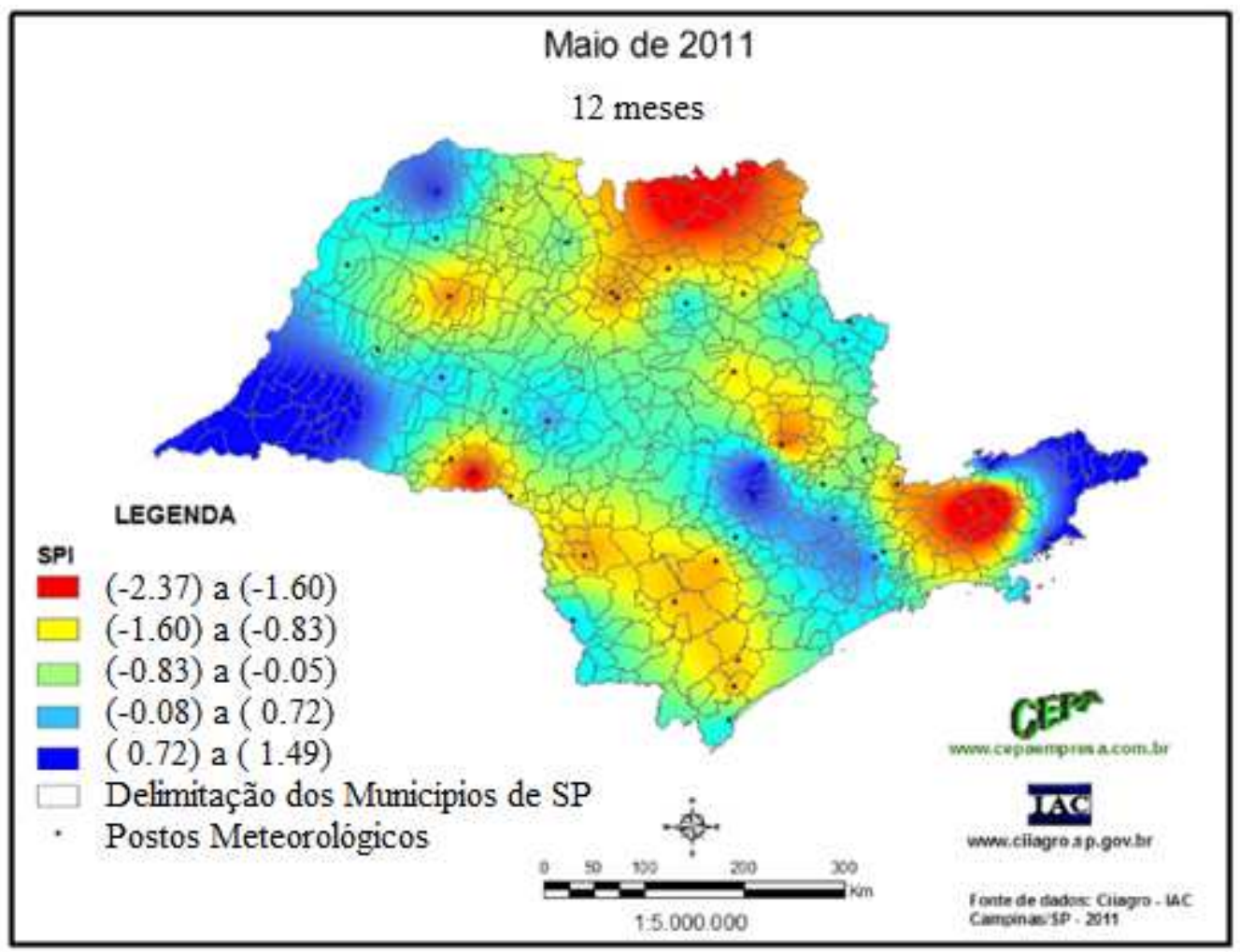

Figura 9- Mapa SPI de 12 meses

Fonte: [32] 


\subsubsection{Regime de ventos}

Não existem dados específicos relacionados ao regime de ventos para o município de Suzano. É possível estimar uma projeção de regime de ventos através do Atlas do Potencial Eólico Brasileiro.

Há também o Mapa Eólico de São Paulo, previsto para ser lançado no segundo semestre de 2012 (pois as medições se iniciaram em abril de 2010 e terminaram no mês de abril de 2011), mas não publicado até o presente momento.

O Atlas Eólico Brasileiro, cuja primeira versão foi publicada em 2001, necessita ser atualizado. O primeiro estudo contempla medições realizadas em uma altura de 50 metros, mas com o avanço tecnológico medições entre 80 e 120 metros já podem ser realizadas.

$\mathrm{Na}$ figura 10 podemos verificar a variação da velocidade média trimestralmente a 50 metro de altura e na figura 11 a variação das direções dos ventos. 


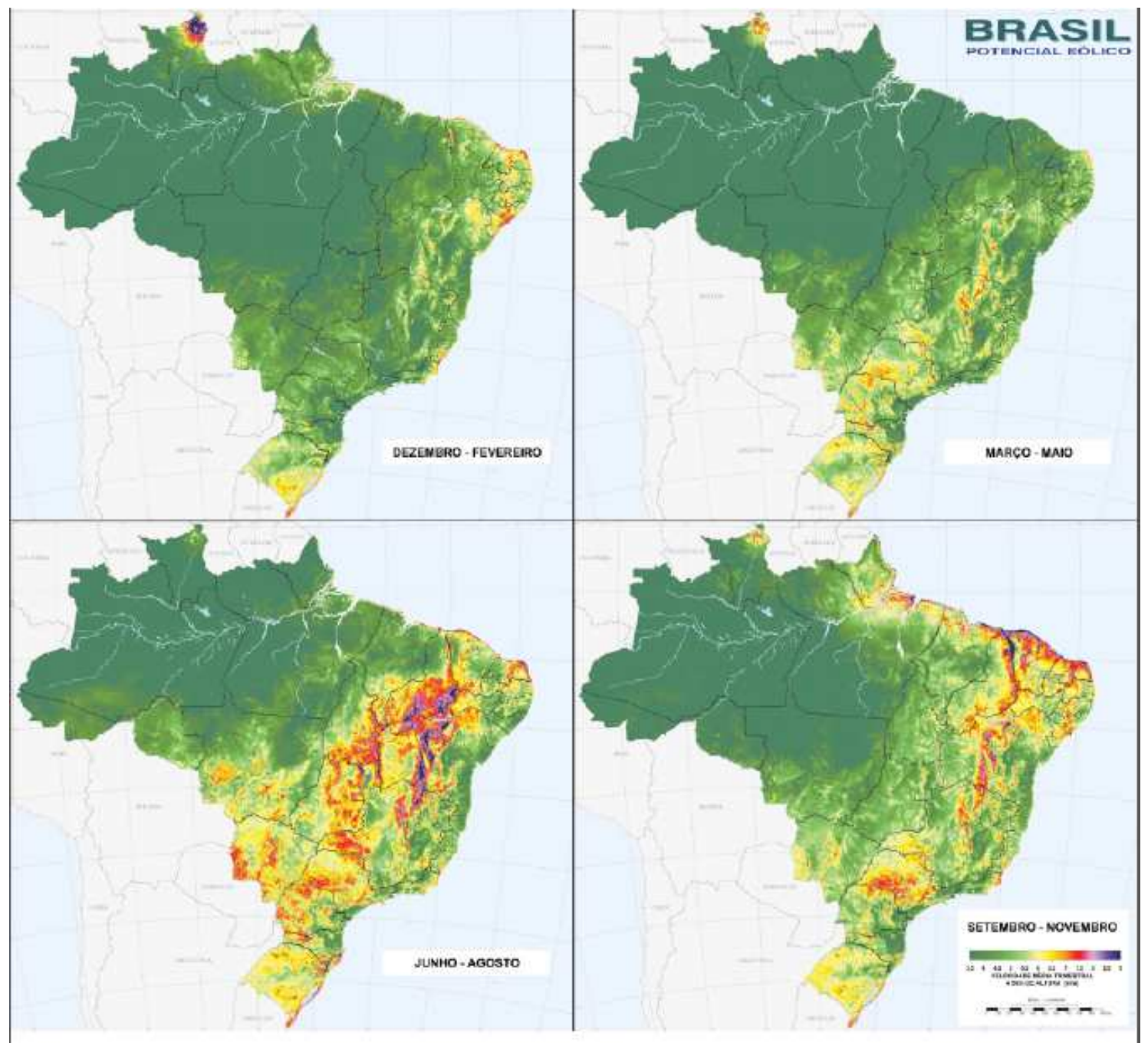

Figura 10- Velocidade média trimestral a $50 \mathrm{~m}$ de altura Fonte: [32] 


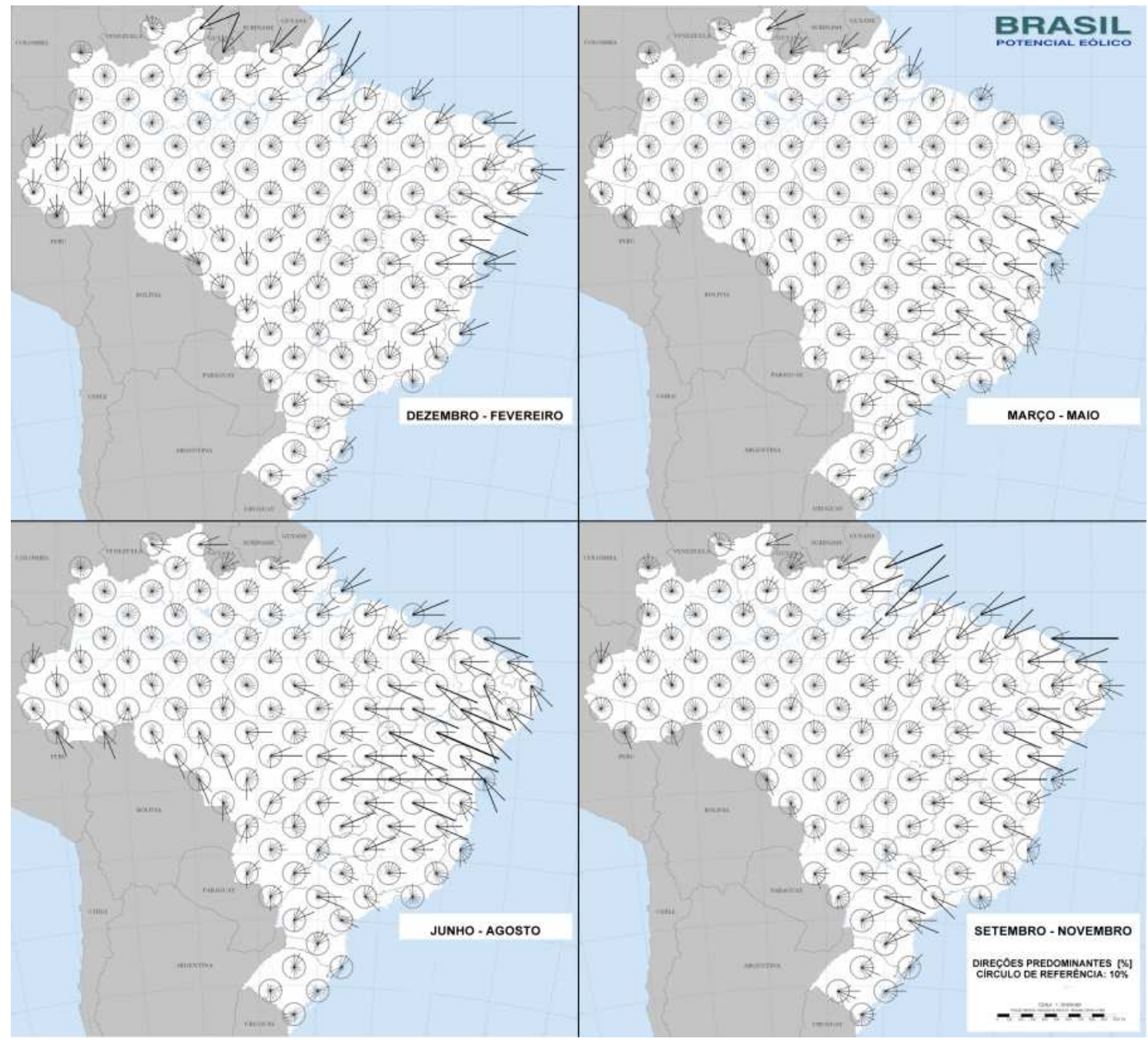

Figura 11- Direções predominantes

Fonte: [33][2001]

\subsubsection{Regime de temperaturas}

Não foi possível encontrar um regime de temperaturas específico do município de Suzano até a finalização deste trabalho.

\subsection{Inventário do meio terrestre}

O município está localizado na sub-região leste da RMSP. Distante 46 km da capital do estado, faz divisa com os municípios de Itaquaquecetuba, Santo André, Rio 
Grande da Serra, Mogi das Cruzes, Poá, Ferraz de Vasconcelos e Ribeirão Pires. Possui uma boa parcela do seu território em áreas de proteção de mananciais.

\subsubsection{Geomorfologia e geologia}

O município de Suzano localiza-se próximo à borda sudeste da bacia sedimentar de São Paulo. Caracteriza-se pela dominância de formas de relevo suavizadas, com altitudes entre 715 e 900 metros, organizadas em sistemas de morretes alongados paralelos, morros baixos e morros paralelos. Cruzando uma larga faixa a centro-norte do município está a planície aluvionar do rio Tietê, cujo principal afluente local, o rio Taiaçupeba-açu, está represado na porção territorial centro-leste de Suzano [19].

O entorno da represa Taiaçupeba é marcado por colinas suaves. Nas planícies aluviais existe o predomínio de baixas declividades, inferiores a 5\%, e o nível freático é pouco profundo [19].

Nas colinas, a topografia é suavizada, com predomínio de amplitudes de 40m e declividades de até $20 \%$. Nos morrotes, predominam amplitudes de $50 \mathrm{~m}$ e declividades de $20 \%$, com ocorrências restritas de áreas com declividades maiores que $30 \%$. Nos morros baixos, a predominância é de amplitudes de $100 \mathrm{~m}$ e declividades de $30 \%$, já nos morros altos predominam amplitudes e declividades elevadas, de $150 \mathrm{~m}$, e maiores que $30 \%$, respectivamente [19].

Sua geologia (figura 12) é caracterizada pela presença de rochas cristalinas do embasamento pré-cambriano, sedimentos terciários da Formação São Paulo e sedimentos quaternários depositados nas várzeas dos rios atuais [20]. 

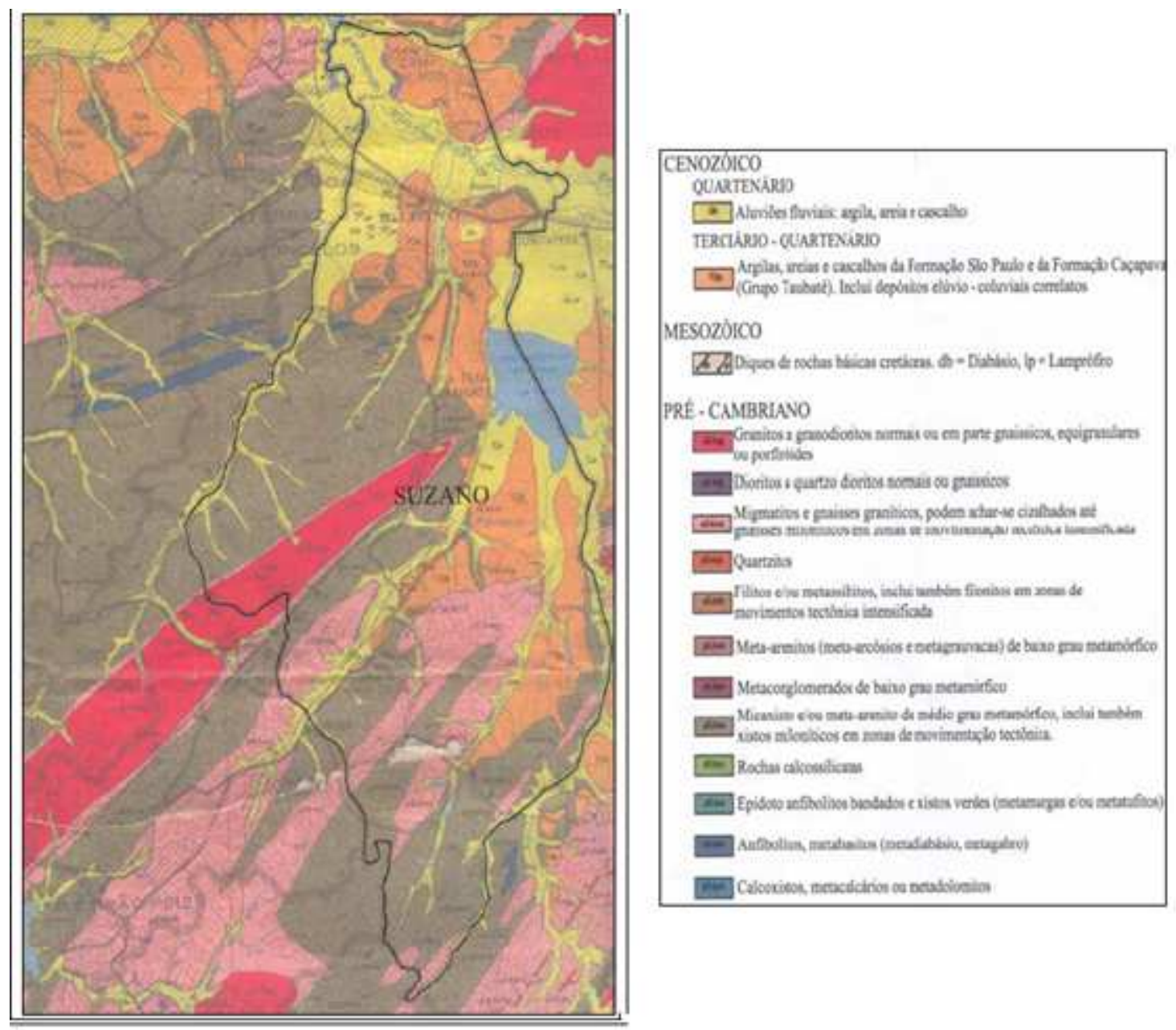

Figura 12- Carta geológica do município de Suzano Fonte: [19]

Foram identificadas algumas áreas contaminadas por produtos tóxicos oriundas de mineradoras, indústrias e postos de combustível.

\subsubsection{Recursos minerais}

Os principais recursos minerais extraídos no município estão localizados junto às bacias hidrográficas, são elas:

- Bacia do Guaió: granito ornamental;

- Bacia do Taiaçupeba: caulim e turfa; 
- Bacia do Tietê Leste: areia, argila e turfa.

Em relação aos problemas inerentes à atividade de mineração, destacam-se:

- Alteração e assoreamento dos cursos d'água;

- Desaparecimento de córregos;

-Antiga extração de argila nas margens da represa Taiaçupeba, sem recuperação ambiental;

- Desmatamento e descaracterização do relevo;

- Formação de cavas de mineração e erosão;

- Depósito sem controle de resíduos sólidos no solo;

- Insalubridade das condições de trabalho.

\subsubsection{Contaminação do solo}

$\mathrm{Na}$ tabela 9 podemos verificar uma relação de registros de contaminações verificados no município de Suzano. Podemos notar que mais da metade dos casos são causados pelas indústrias. 
Tabela 9 - Áreas contaminadas no município de Suzano

\begin{tabular}{|c|c|c|c|c|}
\hline \multicolumn{5}{|c|}{ Áreas Contaminadas no município de Suzano } \\
\hline Responsável & Atividade & $\begin{array}{c}\text { Fonte de } \\
\text { Contaminação }\end{array}$ & Contaminantes & Meios Impactados \\
\hline Auto Posto Kimura & Posto de & Armazenagem & Combustivel líquido & Subsolo \\
\hline Ltda. & Combustivel & & & Águas Subterrâneas \\
\hline Auto Posto São & Posto de & Armazenagem & Solventes Aromáticos, PAHs & Águas Subterrâneas \\
\hline Marco Ltda. & Combustivel & Manutenção & & \\
\hline Auto Posto Suzano & Posto de & Armazenagem & Solventes Aromáticos & Águas Subterrâneas \\
\hline & Combustivel & & PAHs & \\
\hline Produquimica Industria e & Indústria & Armazenagem & Metais & Águas Subterrâneas \\
\hline Comercio Ltda. & & Produção & & \\
\hline Clariant S/A & Indústria & $\begin{array}{l}\text { Descarte } \\
\text { disposição } \\
\text { Produção }\end{array}$ & $\begin{array}{l}\text { Metais, solventes } \\
\text { halogenados, solventes } \\
\text { aromáticos, fenóis } \\
\text { halogenados, biocidas }\end{array}$ & $\begin{array}{l}\text { Solo Superficial } \\
\text { Subsolo } \\
\text { Águas subterrâneas }\end{array}$ \\
\hline Komatsu do Brasil Ltda. & Indústria & Descarte disposição & Metais, Fenóis halogenados & $\begin{array}{l}\text { Solo Superficial } \\
\text { Subsolo } \\
\text { Águas subterrâneas }\end{array}$ \\
\hline Mixmicro Indústria e & Indústria & Descarte & Metais & Solo Superficial \\
\hline Comercio de Produtos & & disposição & & Subsolo \\
\hline Químicos Ltda. & & Produção & & Águas subterrâneas \\
\hline Produquimica Indústria e & Indústria & Armazenagem & Metais & Solo Superficial \\
\hline Comercio Ltda. & & Produção & & Subsolo \\
\hline & & & & Águas subterrâneas \\
\hline
\end{tabular}

Fonte: [25][2010]

\subsubsection{Gestão de resíduos sólidos urbanos}

O município de Suzano possui $82 \%$ de atendimento em coleta da carga orgânica doméstica, um valor baixo em comparação com o município de São Paulo (93\%). Na tabela 10 podemos ver a carga orgânica doméstica na UGRHI 6.

Tabela 10 - Carga Orgânica Doméstica

\begin{tabular}{|c|c|c|c|c|c|c|c|c|}
\hline \multirow[b]{2}{*}{ Município } & \multirow[b]{2}{*}{ Concessão } & \multicolumn{2}{|c|}{ População SEAD 2006} & \multicolumn{2}{|c|}{ Atendimento (\%) } & \multicolumn{2}{|c|}{$\begin{array}{l}\text { Carga Poluidora } \\
\text { (kg DBO/dia) }\end{array}$} & \multirow[t]{2}{*}{ Corpo Receptor } \\
\hline & & Total & Urbana & Coleta & Tratam. & Potencial & Remanesc. & \\
\hline São Bernardo do Campo & DAE & 780.512 & 767.712 & 84 & 3 & 41.456 & 40.621 & $\begin{array}{l}\text { Rib. Do Meninos e } \\
\text { Res. Billings }\end{array}$ \\
\hline São Caetano do Sul & SAEE & 137.277 & 137.277 & 100 & 0 & 7.413 & 7.413 & $\begin{array}{l}\text { Rio Tamanduateí } \\
\text { Rio Tietê, Rio }\end{array}$ \\
\hline São Paulo & Sabesp & 10.834 .244 & 9.975 .563 & 93 & 66 & 538.680 & 274.167 & Pinheiros e Rio \\
\hline Suzano & Sabesp & 278.911 & 271.241 & 82 & 70 & 14.647 & 7.921 & $\begin{array}{l}\text { Tamanduateí } \\
\text { Rio Tietê }\end{array}$ \\
\hline Taboão da Serra & Sabesp & 224.643 & 224.643 & 69 & 0 & 12.131 & 12.131 & Rio Tietê \\
\hline Total UGRHI & & 19.190 .390 & 18.264 .719 & 81 & 37 & 986.295 & 691.943 & \\
\hline
\end{tabular}

Fonte: [34][2007] 
$\mathrm{Na}$ tabela 11 podemos verificar a disposição final de resíduos sólidos domésticos na UGRHI 6.

Tabela 11 - Disposição final de resíduos sólidos domésticos

\begin{tabular}{|c|c|c|c|c|c|c|c|c|c|c|c|c|c|c|c|c|c|c|c|c|c|}
\hline \multirow{3}{*}{ MUNICÍPIO } & & \multirow{3}{*}{$\begin{array}{l}\text { AGÊNCIA } \\
\text { CETESB }\end{array}$} & \multirow{3}{*}{ UGRHI } & \multirow{3}{*}{\begin{tabular}{|l} 
Lixo \\
$($ t/dia $)$
\end{tabular}} & \multicolumn{16}{|c|}{ INVENTÁRIO } & \multirow{3}{*}{$\begin{array}{l}\text { ENQUADRAMENTO } \\
\text { E OBSERVAÇÃO }\end{array}$} \\
\hline & & & & & \multicolumn{2}{|c|}{1997} & \multicolumn{2}{|c|}{\begin{tabular}{|l|}
1999 \\
\end{tabular}} & \multicolumn{2}{|c|}{2001} & \multicolumn{2}{|c|}{2003} & \multicolumn{2}{|c|}{2005} & \multicolumn{2}{|c|}{2007} & 2008 & \multicolumn{2}{|c|}{2009} & \begin{tabular}{|l|}
2010 \\
\end{tabular} & \\
\hline & & & & & \begin{tabular}{|l|} 
IQR \\
02
\end{tabular} & IQC & IQR & $\mathrm{IQC}$ & \begin{tabular}{|l|l|} 
IQR & I \\
\end{tabular} & & \begin{tabular}{|l|l|} 
IQR & I \\
\end{tabular} & IQC & \begin{tabular}{l|l}
$\mathrm{IQR}$ & 1 \\
\end{tabular} & IQC & & IQC & \begin{tabular}{|l|l|l} 
IQR & IQC \\
\end{tabular} & IQR & $\mathrm{IQC}$ & \begin{tabular}{|l|l|l} 
IQR & IQC \\
\end{tabular} & \\
\hline RTO GRANDE DA SERRA & & $\mathrm{ABCI}$ & 6 & 17,6 & 8,2 & & 8,4 & & \begin{tabular}{|l|}
9,7 \\
\end{tabular} & & \begin{tabular}{|l|}
9,8 \\
\end{tabular} & & 9,2 & & 9,5 & & \begin{tabular}{|l|l|}
9,4 & \\
\end{tabular} & 9,7 & & \begin{tabular}{|c|}
9,4 \\
\end{tabular} & \begin{tabular}{l|l} 
A & D - Mauá - A.P. \\
\end{tabular} \\
\hline SALESOPOLIS & * & Mogi das Cruzes & 6 & 4,0 & 5,8 & & 4,8 & & 6,5 & & 6,2 & & 6,6 & & 6,7 & & 6,5 & 7,9 & & 8,2 & \begin{tabular}{|l|l} 
A & - Itaquaquecetuba - A.P. \\
\end{tabular} \\
\hline SANTANA DE PARNAIBA & & Osasco & 6 & 54,4 & 3,3 & & 3,2 & & 3,8 & & 3,8 & & 9,8 & & 6,5 & & 5,2 & 6,2 & & 4,9 & \begin{tabular}{|l|l|}
$\mathrm{I}$ & \\
\end{tabular} \\
\hline SANTO ANDRE & ${ }^{*}$ & $\mathrm{ABCI}$ & 6 & 471,7 & 8,2 & & 8,9 & & 9,3 & & 9,3 & & 9,3 & & 9,3 & & 8,9 & 6,1 & & 9,4 & \begin{tabular}{|l|l|} 
A & D - Maua - A.P. \\
\end{tabular} \\
\hline SAO BERNARDO DO CAMPO & & $\mathrm{ABC}$ II & 6 & 526,7 & 7,0 & & 8,4 & & 9,7 & & 9,8 & & 9,2 & & 9,5 & & 9,4 & 9,7 & & 9,4 & \begin{tabular}{|l|l} 
A & D - Maua - A.P. \\
\end{tabular} \\
\hline SÁO CAETANO DO SUI & * & $\mathrm{ABCI}$ & 6 & 74,8 & 7,0 & & 8,4 & & 9,7 & & 9,8 & & 9,2 & & 9,5 & & 9,4 & 9,7 & & 9,4 & \begin{tabular}{|l|l} 
A & D - Mauá - A.P. \\
\end{tabular} \\
\hline SÁO PAULO & & Tatuapé & 6 & $6.000,0$ & 0,0 & & 0,0 & & 0,0 & & 0,0 & & 0,0 & & 0,0 & & 0,0 & 0,0 & & 9,3 & \begin{tabular}{|l|l|l|l|} 
A & D - São Paulo - A.P. \\
\end{tabular} \\
\hline SÁO PAULO & & Osasco & 6 & $5.000,0$ & 0,0 & & 8,5 & & 9,0 & & 0,0 & & 9,6 & & 9,6 & & 9,6 & 9,5 & & 8,2 & \begin{tabular}{|l|l|} 
A & D - Caieiras - A.P. \\
\end{tabular} \\
\hline SUZANO & $\S$ & Mogi das Cruzes & 6 & 152,0 & 5,6 & & 8,2 & & 7,8 & & 6,3 & & 6,2 & & 7,1 & & 8,0 & 7,9 & & 8,2 & \begin{tabular}{|l|l} 
D - Itaquaquecetuba - A.P. \\
\end{tabular} \\
\hline TABOAO DA SERRA & & Embu & 6 & 146,8 & 7,3 & & 8,6 & & $\overline{p, 0}$ & & 8,8 & & 9,1 & & 9,6 & & 9,6 & 9,5 & & 8,2 & \begin{tabular}{|l|l|} 
D - Caieiras - A.P. \\
\end{tabular} \\
\hline
\end{tabular}

Fonte: [37][2011]

Pela figura 13, podemos notar que a qualidade de aterro do município de Suzano é adequada.

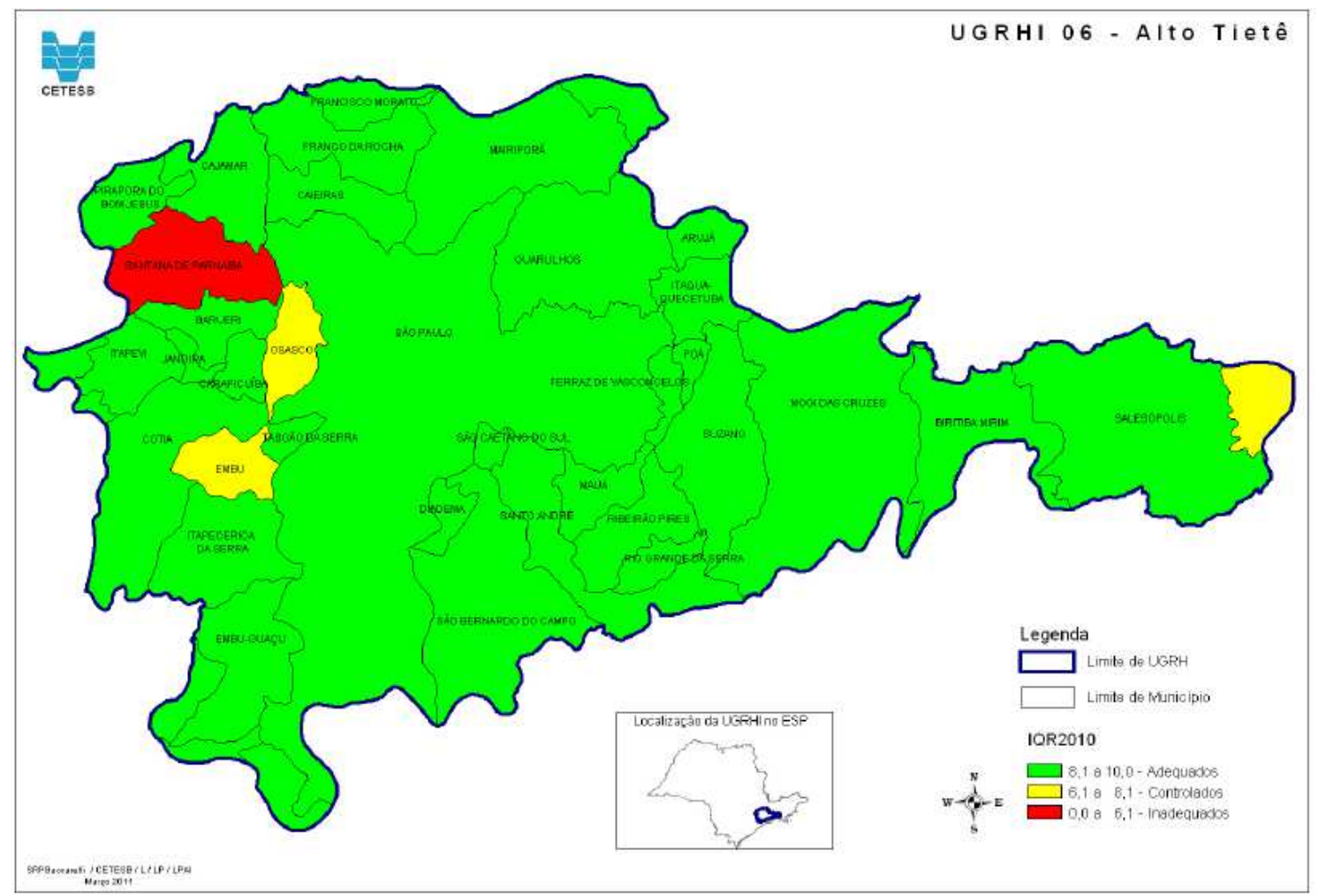

Figura 13 - Mapa da UGRHI 6 - Índice de qualidade de aterro resíduos

O município de Suzano não assinou o Termo de Compromisso de Ajustamento de Conduta (TCAC), no qual são consignados os compromisso dos 
municípios para a regularização ou o encerramento de aterros irregulares e lixões e adoção de uma solução técnica definitiva e regularmente implantada.

\subsubsection{Erosão}

A região do município de Suzano possui uma criticidade média com relação à erosão do solo.

\subsubsection{Vegetação remanescente}

De um total 3.188 hectares, o município de Suzano possui 17,2\% (tabela 12) da sua vegetação natural remanescente. Essa vegetação é constituída basicamente de mata e vegetação capoeira (vegetação secundária constituída por gramíneas e arbustos).(figura 14)

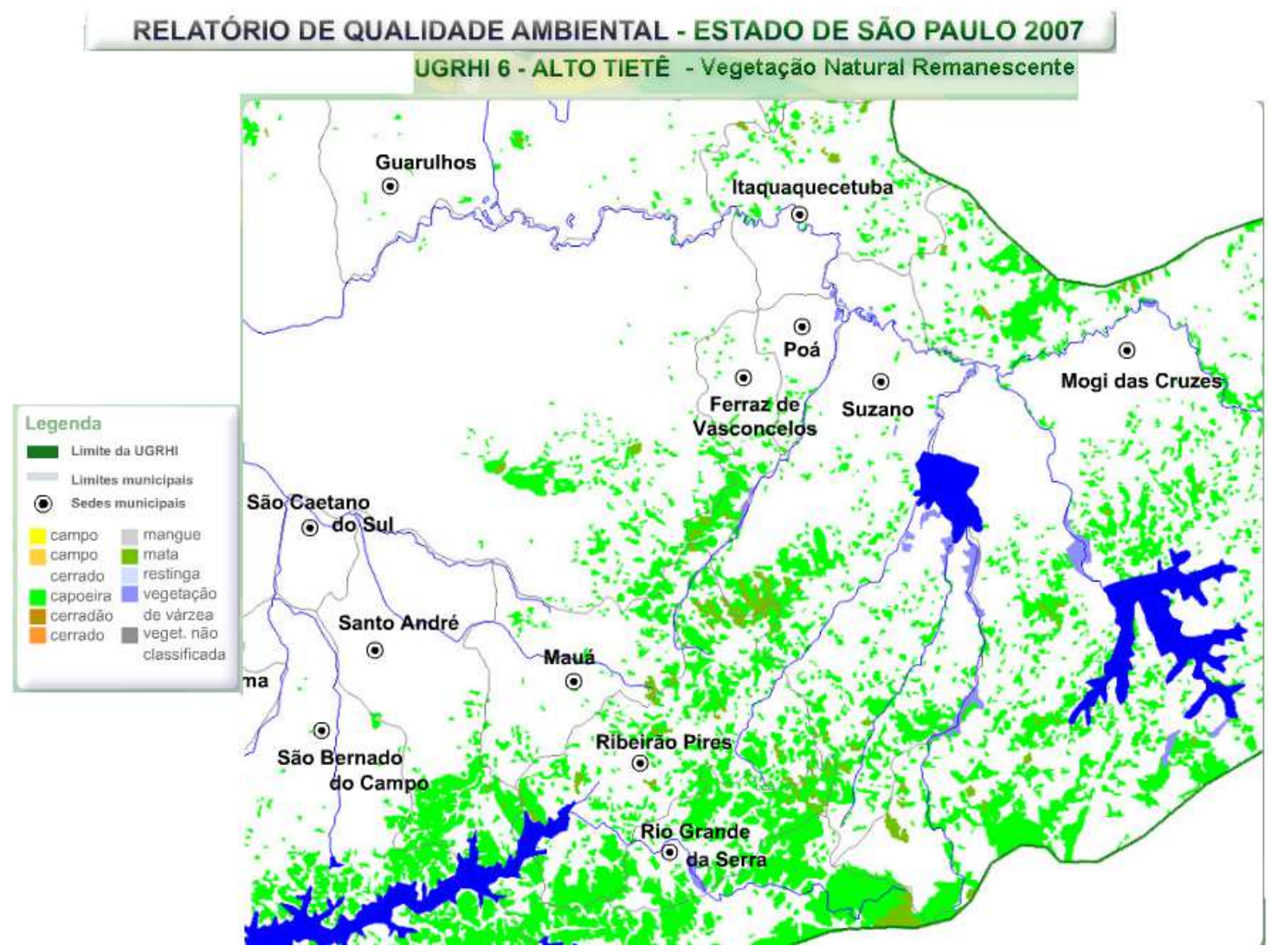

Figura 14 - Vegetação remanescente

Fonte: [34] 
Tabela 12 - Vegetação remanescente

\begin{tabular}{cccc}
\hline Município & Área (ha) & $\begin{array}{c}\text { Vegetação } \\
\text { Natural } \\
\text { Remanescente } \\
\text { (ha) }\end{array}$ & $\%$ \\
\hline Suzano & 18.500 & 3.188 & 17,2 \\
\hline
\end{tabular}

Fonte: [34] [2007]

\subsection{Inventário do meio aquático}

O município de Suzano é banhada pela bacia hidrográfica do Alto Tietê-Cabeceiras, subdivididas pelas bacias do Taiaçupeba, do Guaió e do Tietê Leste. Seus principais cursos de água são: rio Tietê, rio Guaió, rio Taiaçupeba, ribeirão do Uma, rio Jaguari e córrego Balainho.

A bacia do Tietê Leste (com 62,2 km²), em Suzano, subdivide-se em [18]:

- Sub-bacia do Ribeirão Jaguari;

- Sub-bacia dos tributários do Tietê Leste I;

- Sub-bacia dos tributários do Tietê Leste II;

- Sub-bacia dos tributários do Tietê Leste III;

- Sub-bacia do ribeirão Varginha;

- Sub-bacia do Guaió;

- Sub-bacia do Taiaçupeba II.

A bacia do Taiaçupeba, com 108,1 km², divide-se em:

- Sub-bacia do rio Taiaçupeba I;

- Sub-bacia do ribeirão Balainho;

- Sub-bacia do rio Taiaçupeba-Mirim.

A bacia do Guaió tem 26,2 km².

O abastecimento do município é realizado pelo distribuidor principal do 
Sistema Alto Tietê e Alça Suzano/Bráz Cubas e possui uma reserva com capacidade de $10.000 \mathrm{~m}^{3}[15]$.

O município de Suzano está inserido no sistema integrado de tratamento de esgotos da região metropolitana de São Paulo e conta com a Estação de Tratamento de Esgoto de Suzano desde 1982. A coleta de esgotos em 2009 foi de 82\% [16].

No caso da fábrica em questão, a água utilizada no processo é tratada em Estações de Tratamento de Água (ETA) próprias. Em 2009, o consumo de água foi de $24.108 .936 \mathrm{~m}^{3}$ [17], correspondendo a uma retirada de água de $3,03 \%$ do rio Tietê.

O tratamento de efluentes é realizado na própria fábrica em Estações de Tratamento de Efluentes (ETE). Em 2009 foram gerados 24.952.374m³ [15] de efluentes.

O município de Suzano pertence ao UGRHI 6, composto de 34 municípios que concentram $47,4 \%$ da população do estado, sendo que $96 \%$ dos habitantes vivem em áreas urbanas.

Na figura 15 podemos verificar as sub-bacias que compõem a Bacia de Alto Tietê. 


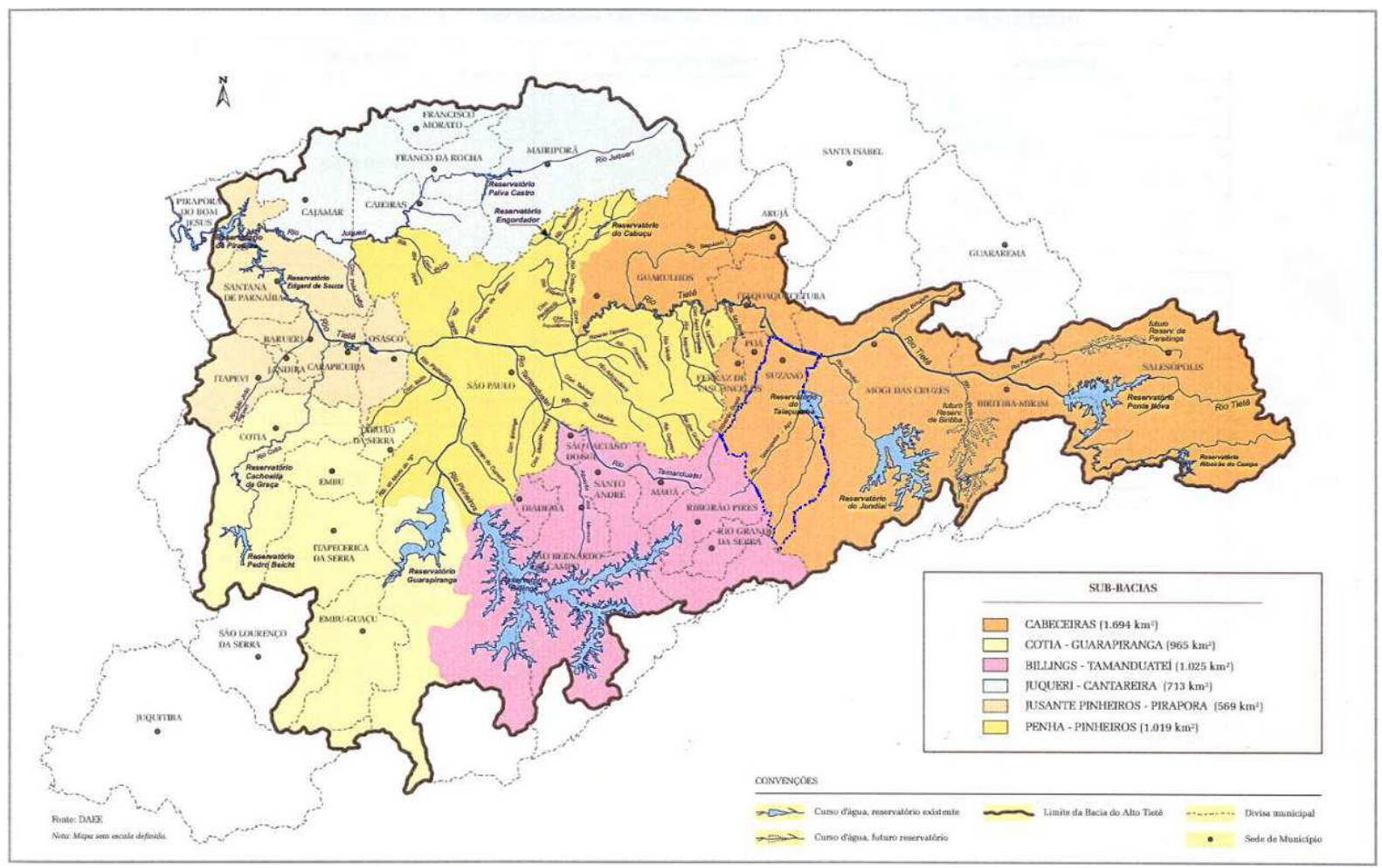

Figura 15 - Bacia do Alto Tietê

Fonte: [29]

\subsection{1 Águas superficiais - qualidade}

$\mathrm{Na}$ figura 16 podemos verificar a rede de monitoramento da rede básica da UGRHI 6. O município de Suzano possui quatro pontos de amostragem. 


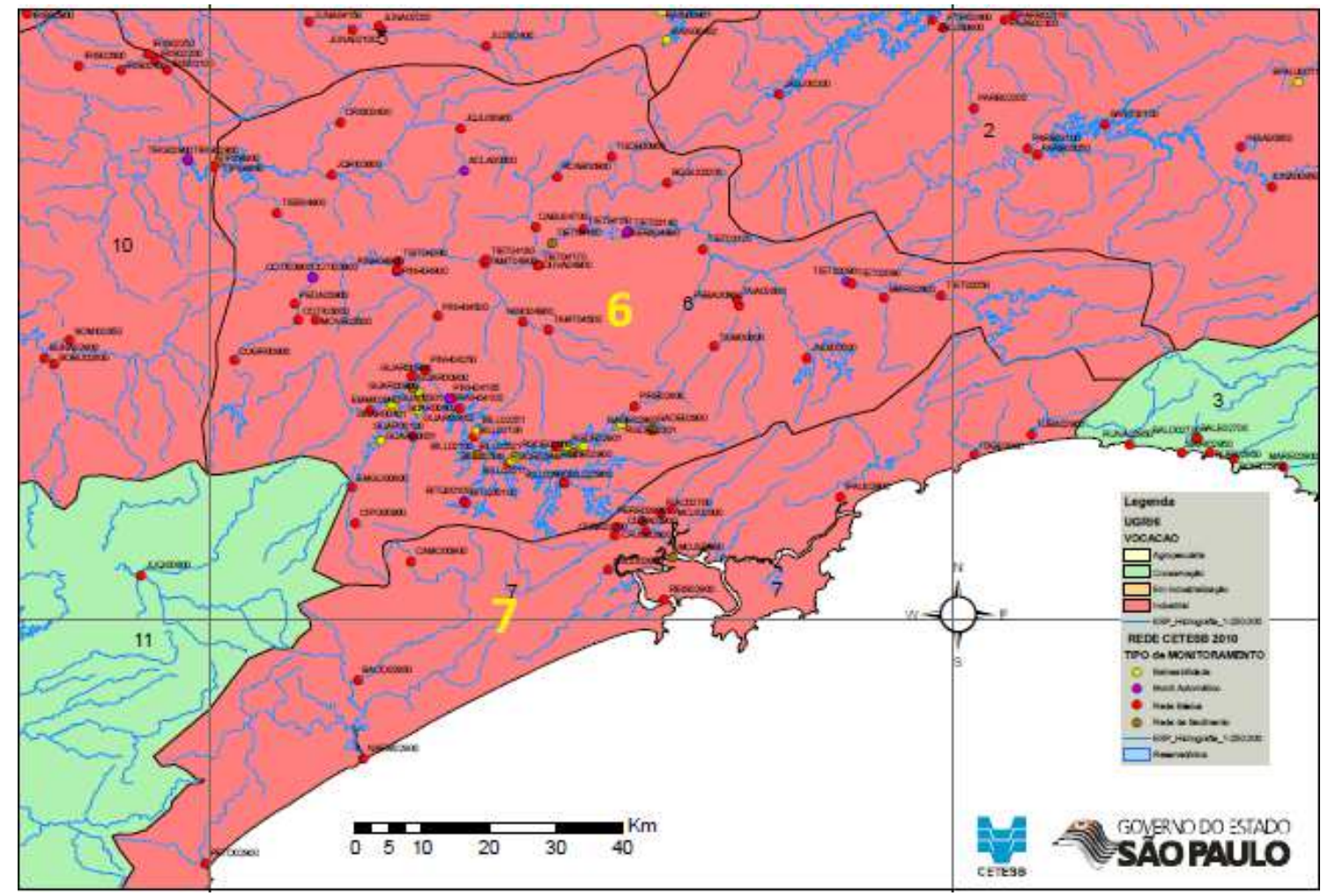

Figura 16 - Rede de monitoramento da rede básica UGRHI 6 e 7

Fonte: [36]

O IQA indica o impacto do lançamento de esgotos predominantemente domésticos no corpo d'água. Na Figura 17, é possível observar uma piora sensível no índice no trecho crítico (Suzano a Botucatu)(cores vermelho, lilás e amarelo. Também podemos verificar pela mesma figura que em Suzano houve uma pequena melhora em relação ao ano passado.(em cinza temos o histograma da média de 2010) 


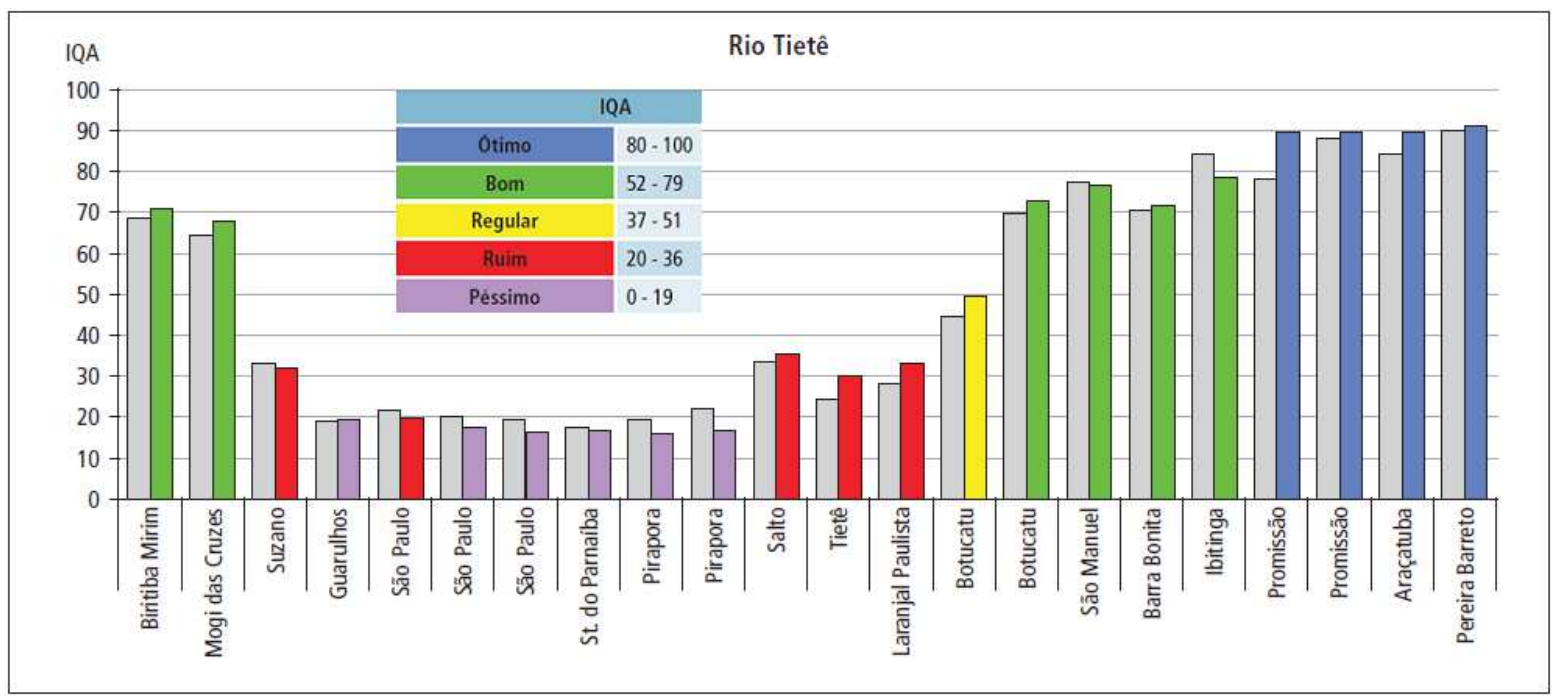

Figura 17 - Perfil do IQA ao longo do rio Tietê em 2011

Fonte: [36]

\subsection{2 Águas subterrâneas - qualidade}

A qualidade das águas subterrâneas é monitorada através de uma rede de monitoramento (figura 18). As águas subterrâneas representam um dos mais importantes recursos naturais devido à utilização para o atendimento atual e futuro de diversas demandas de uso. Deste modo é importante monitorar sua qualidade. 


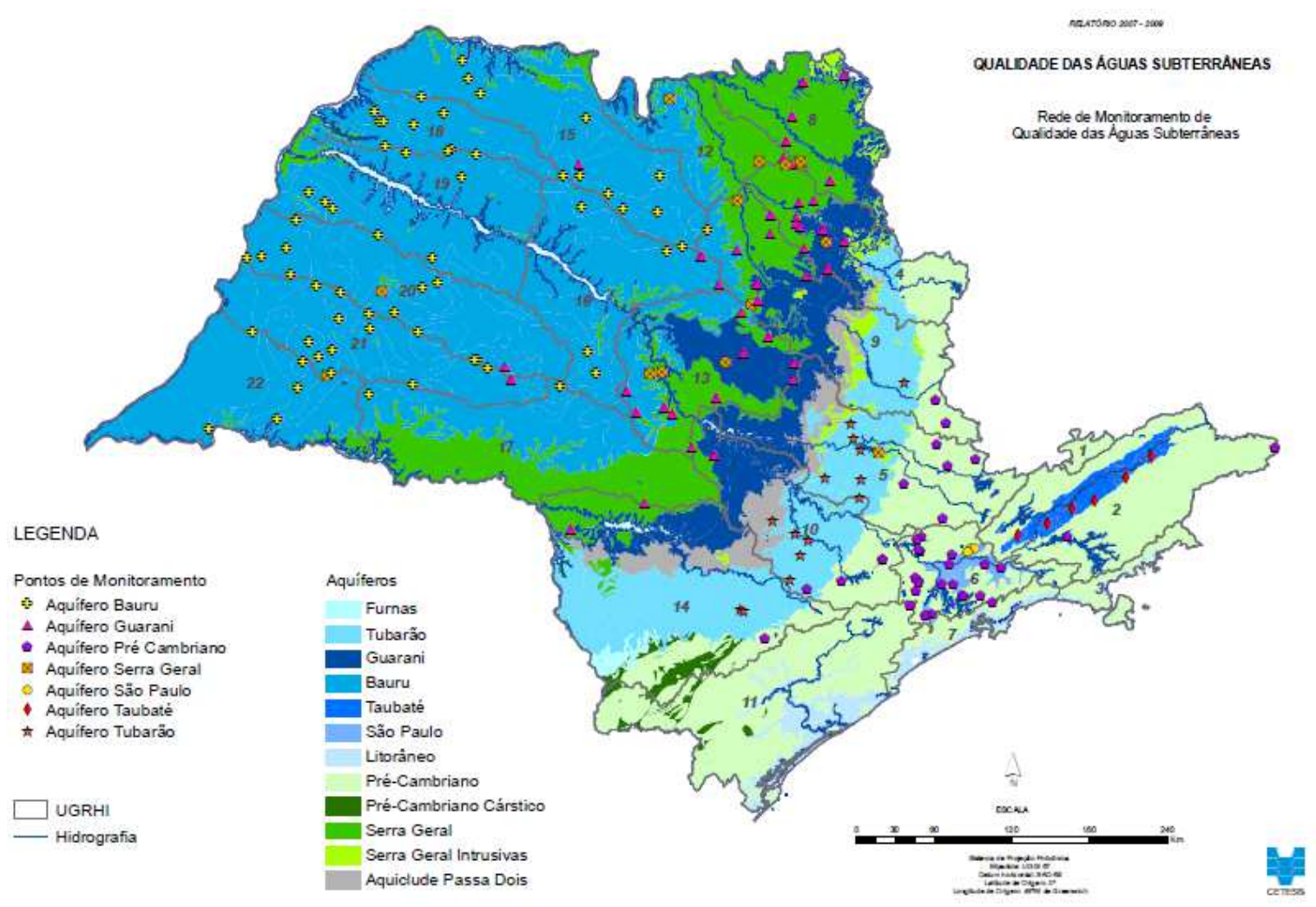

Figura 18 - Rede de monitoramento e seus aquíferos

Fonte: [35]

$\mathrm{Na}$ figura 19 podemos verificar vários dados relativos a qualidade de águas superficiais em Suzano. 


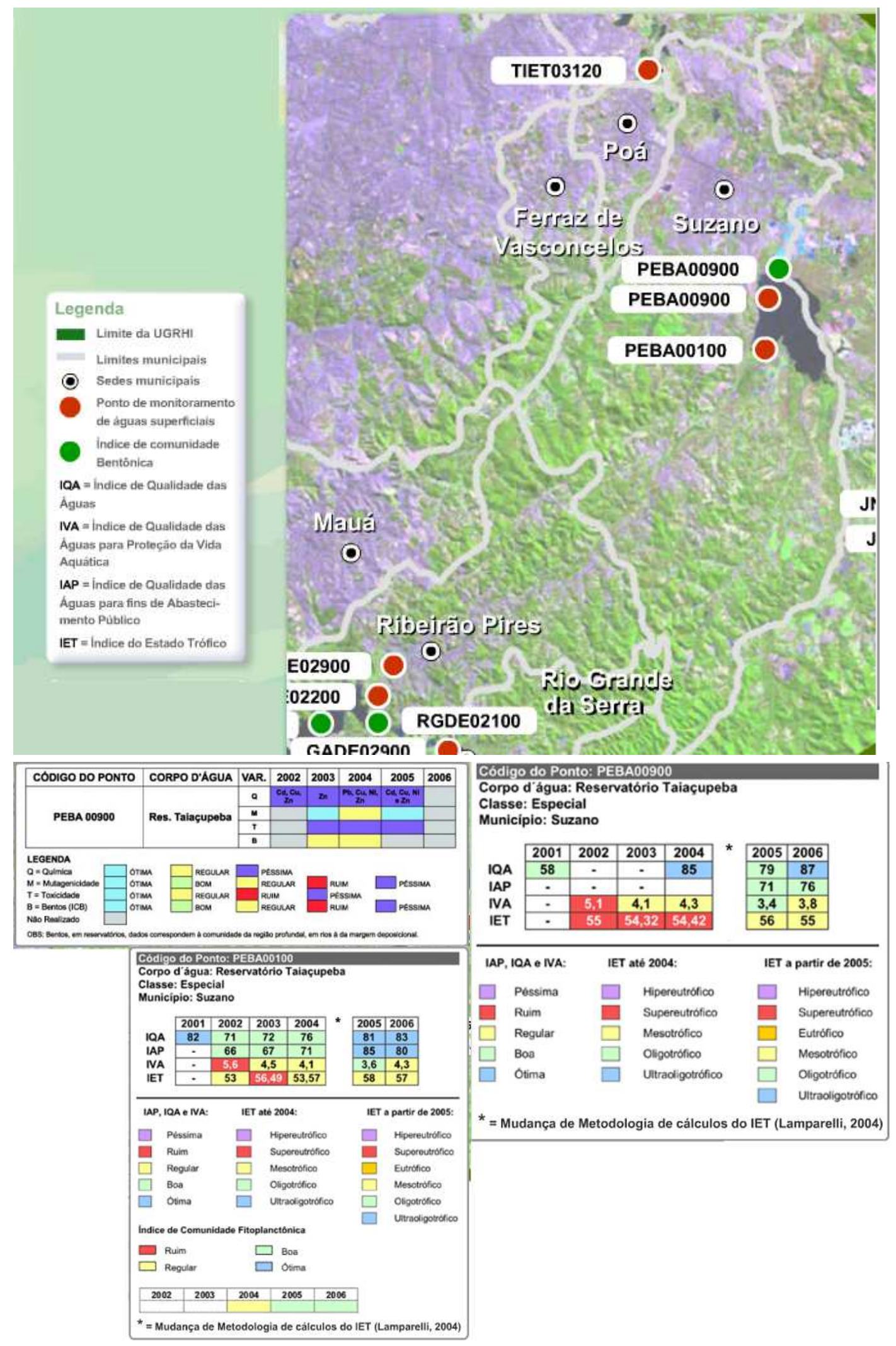

Figura 19 - Mapa de qualidade das águas superficiais em Suzano

Fonte: [34][2007] 
Também se pode verificar a situação do uso das águas subterrâneas do estado de São Paulo na figura 20:

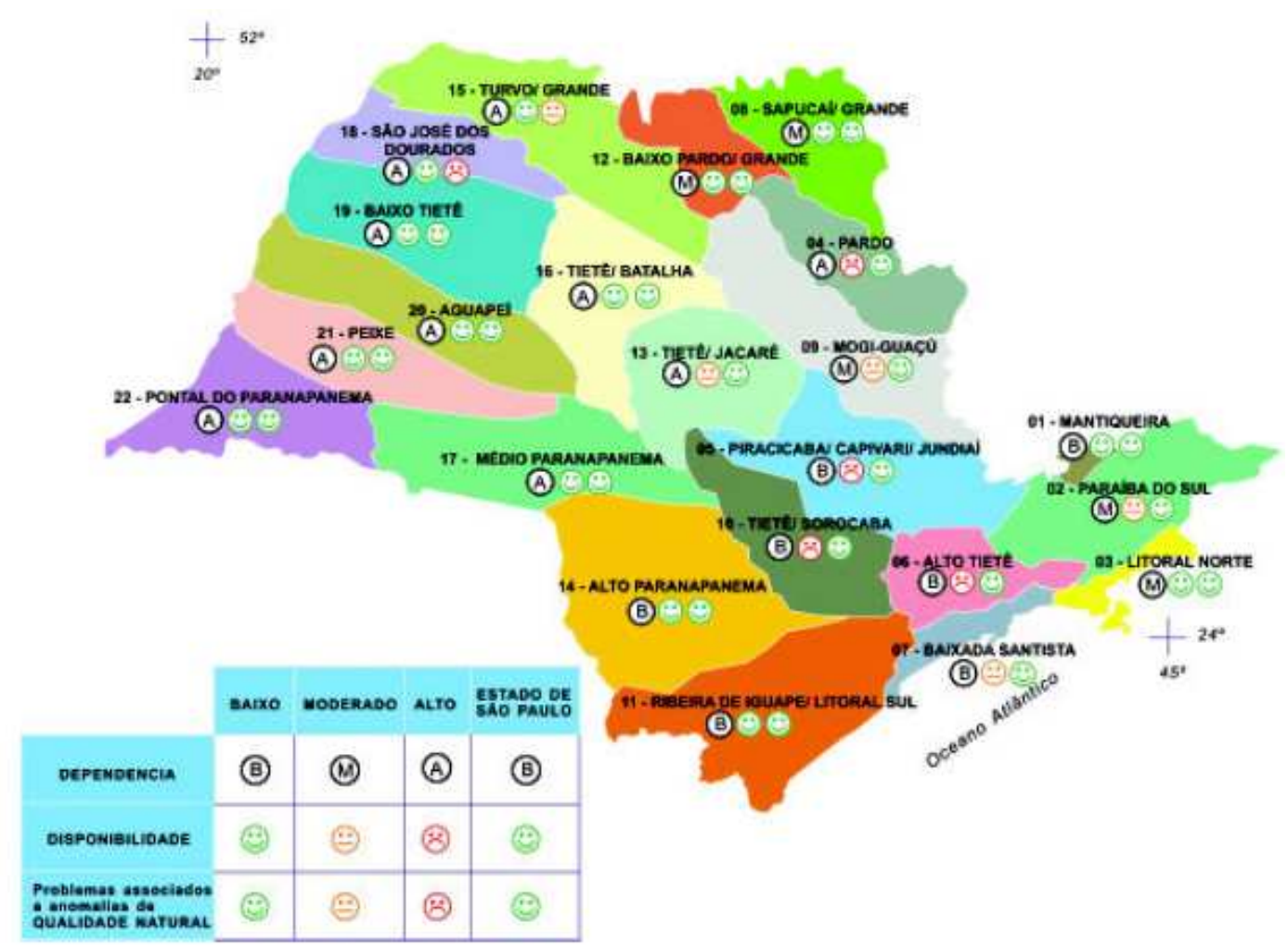

Fonte: Eloborodo por HifATA etel. linedito)

Figura 20 - Situação das águas subterrâneas

Fonte: [30][2005]

\subsection{Inventário do meio antrópico}

\subsubsection{Histórico da região}

A colonização no estado de São Paulo começou em 1532, quando Martim Afonso de Souza fundou a povoado que iria transformar-se na Vila de São Vicente. Dando continuidade à exploração, um grupo de jesuítas, do qual participaram José de Anchieta e Manoel da Nóbrega, escalou a Serra do Mar, chegando ao Planalto de Piratininga, onde fundaram um colégio em 25 de janeiro de 1554. 
$\mathrm{Na}$ segunda metade do século XVII, começaram as viagens de reconhecimento ao interior do país pelos bandeirantes. Ao longo de todo o século XVIII, continuaram as expedições, contribuindo para a ampliação do território brasileiro a sul e sudoeste, além das linhas do Tratado de Tordesilhas.

Em 1815, a cidade se transformou em capital da Província de São Paulo. No final do século XIX São Paulo, tornou-se um importante centro econômico com a expansão da cafeicultura. Durante esse período e início do século $X X$, inicia-se a corrida para o oeste, em busca de terras férteis para as novas plantações de café.

Os primeiros registros sobre as terras que hoje constituem Suzano datam de 1874 ou 1875, quando foram implantados os trilhos da Estrada de Ferro São Paulo-Rio de Janeiro, levando indícios de civilização à região. Alguns anos mais tarde, em 1879, no desempenho de suas funções, Antonio Marques Figueira, feitor da Estrada de Ferro Central, estabeleceu-se na região.[19]

Em 1890 foi solicitada a elaboração da planta da cidade, trabalho executado pelo conde de Romariz, e, consolidando a implantação desse novo povoado, os irmãos Figueira construíram uma igreja, tendo a 20 de janeiro de 1897, data consagrada a São Sebastião, celebrado sua primeira missa. Daí então, a vila passou a ser conhecida por "São Sebastião do Guaió". [19]

A Estrada de Ferro Central do Brasil foi inaugurada em 1875, ligava a cidade de São Paulo a Mogi das Cruzes e possuía somente as estações de Lajeado, atual Guaianases, e Parada Piedade. Com o aumento do fluxo migratório ao redor da ferrovia, surgiram novos bairros, como o Rio Abaixo e o Palmeiras, além dos que já existiam: Baruel e Guaió. Na década de 1890, com o advento da República no Brasil, os moradores da Vila do Guaió decidiram que a velha parada de reabastecimento fosse transformada em estação para embarque e desembarque de passageiros. $O$ 
trabalho de viabilização desse projeto ficou a cargo do senhor Joaquim Augusto Suzano Brandão, engenheiro residente da Estrada de Ferro Central do Brasil que concretizou a obra. Em dezembro de 1907, a Parada Piedade passou a chamar-se Estação Suzano, homenagem a seu idealizador, que acabou emprestando seu nome também à cidade. [19]

Devido aos constantes desenvolvimentos e aumento da população, justificou-se a elevação para a categoria de distrito, anexo ao município de Mogi das Cruzes, em 27 de dezembro de 1919, segundo determinação da Lei Estadual $\mathrm{n} \cong$ 1705, promulgada pelo então presidente do estado Dr. Altino Arantes.

Finalmente, a 8 de dezembro de 1948, foi promulgada a Lei 233 (que entrou em vigor em 1ํ de janeiro de 1949) pelo então governador do estado doutor Adhemar Pereira de Barros, pela qual, dentre outros municípios, Suzano atingiu a condição de município autônomo, com direito a dirigir a sua própria política, procurando o seu desenvolvimento. [19]

O aniversário do município é comemorado no dia 2 de abril, data que coincide com a posse do primeiro prefeito do município. [19]

\subsubsection{Aspectos demográficos}

As unidades territoriais de pesquisa adotadas são as definidas pelo IBGE, onde as menores unidades de dados são os Setores Censitários. Das unidades intermediárias que o IBGE adota, entre os setores censitários e o município, estão os distritos. Dessa forma, o município é dividido em três distritos: Centro, Boa Vista e Palmeiras (figura21). 


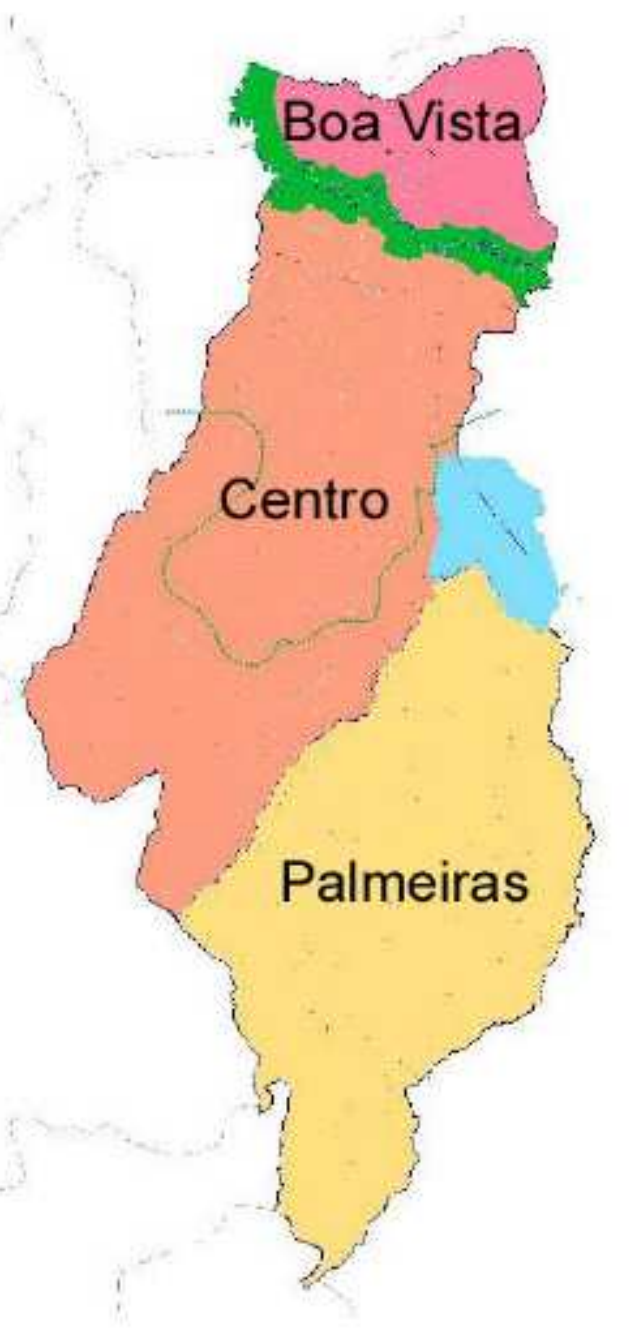

Figura 21 - Divisão de distritos do município de Suzano segundo Censo de 2000 Fonte: [19] 


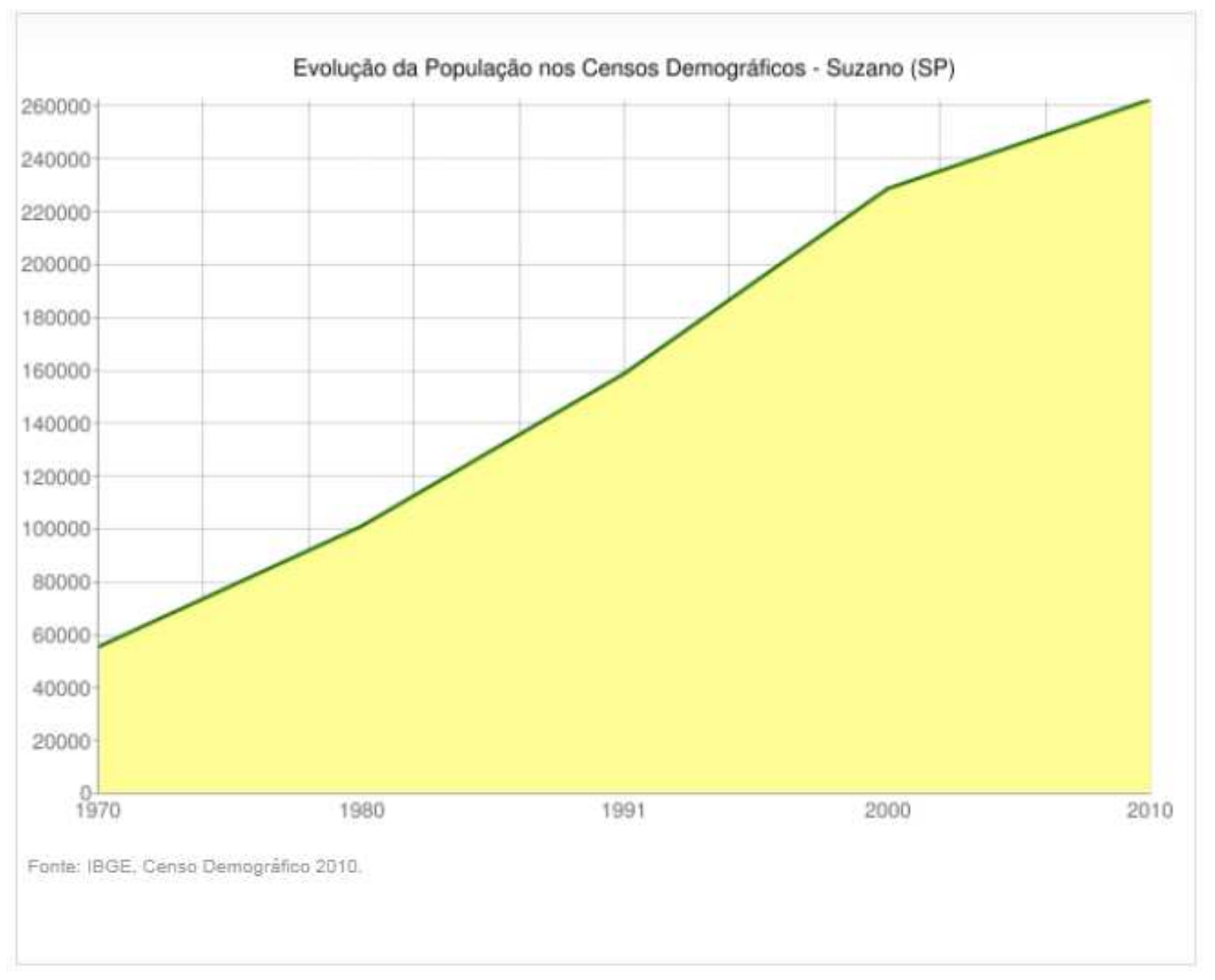

Figura 22 - Evolução da população de 1970 a 2010

Fonte: [14]

É um município na região metropolitana do estado de São Paulo. Sua população em 2011 [13] é de 265.687 habitantes e com área de 205,87 km², resultando numa densidade demográfica de 1.290,56 hab. $/ \mathrm{km}^{2}$ (2011) e grau de urbanização de 96,48\%. Possui uma taxa de crescimento populacional (2000-2011) de $1,40 \%$ ao ano e uma taxa de natalidade (por mil habitantes, em 2009) de 16,82. Na figura 22 acima podemos verificar um gráfico mostrando e evolução da polulação entre os anos de 1970 a 2010.

O gráfico a seguir (figura 23) mostra a pirâmide etária e sexo. Podemos verificar as diferenças entre os anos de 2000 e 2010 e comparar com os gráficos do estado de São Paulo. Através destes gráficos, pode-se verificar que o município de 
Suzano se aproximou da distribuição do estado de São Paulo.
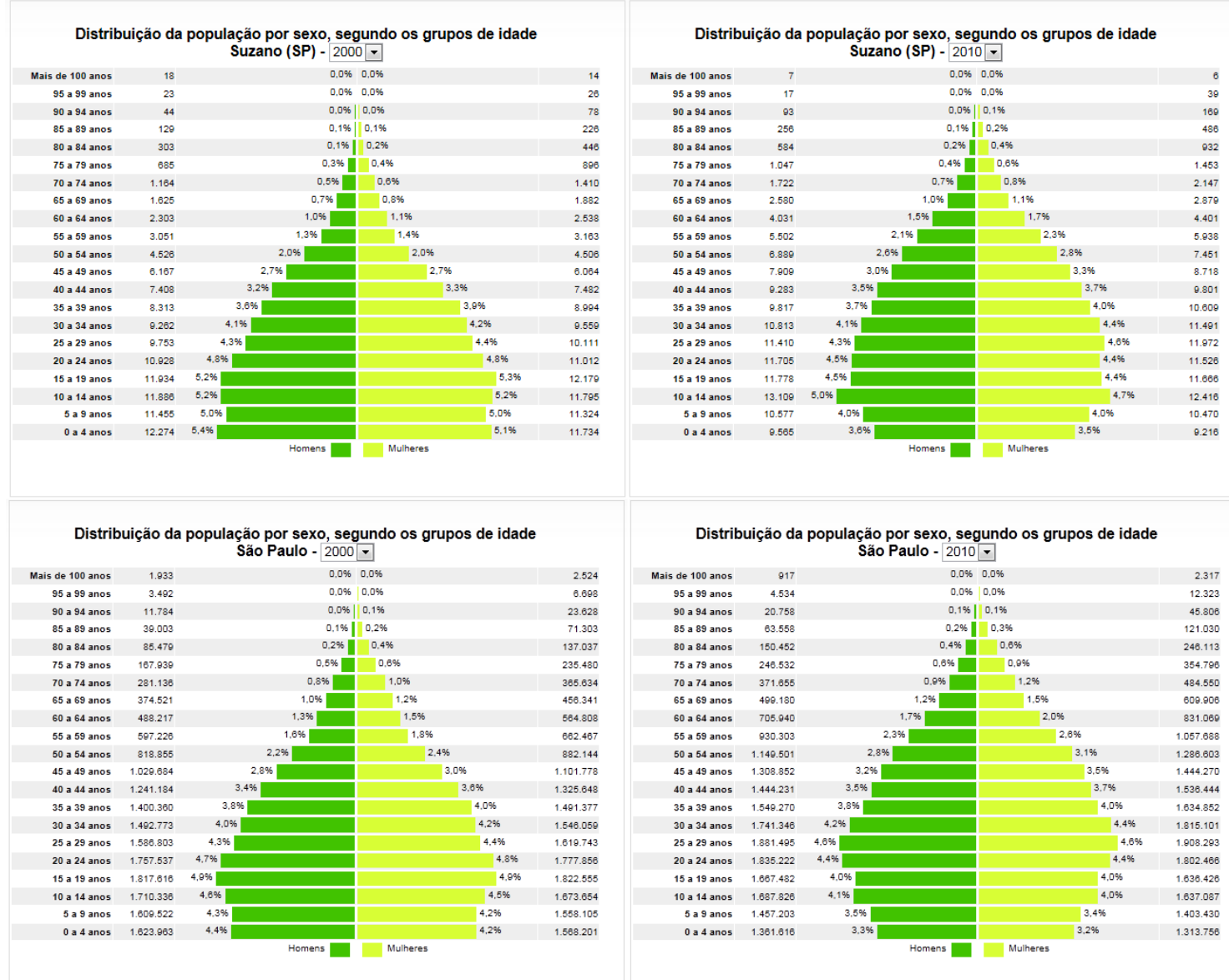

Figura 23 - Distribuição da população por sexo, município de Suzano, na parte superior, e estado de São Paulo, na parte inferior.

Fonte: [14]

A população de Suzano está distribuida em 3,5 \% na área rural e 96,5 \% na área urbana.(figura 24) 


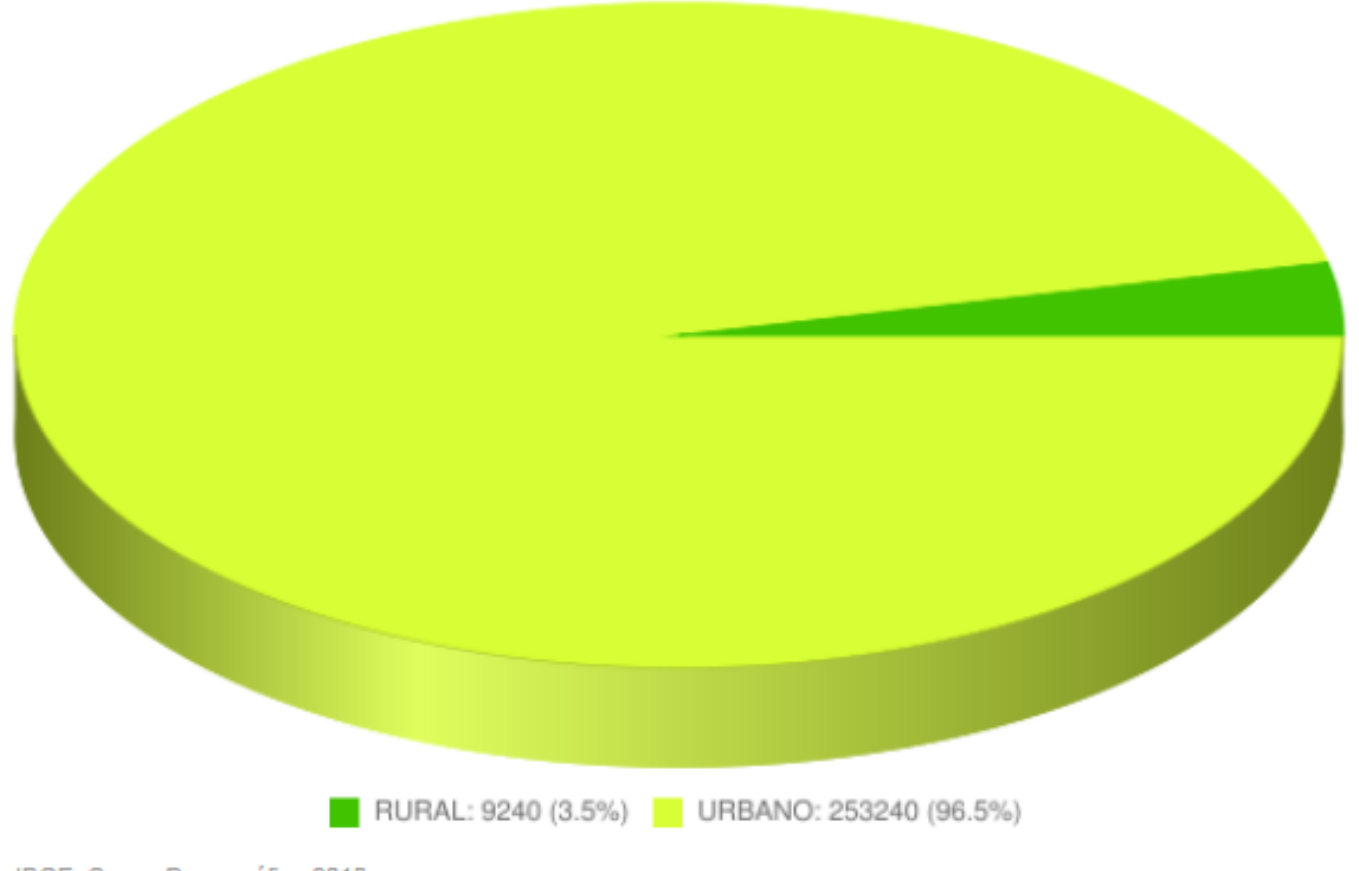

Figura 24 - Distribuição da população entre rural e urbano Fonte: [14]

O Índice de Desenvolvimento Humano (IDH em 2000) era 0,775. O nível de atendimento de coleta de lixo atinge $97,21 \%$ (2000). A taxa de analfabetismo da população de 15 anos e acima é de 7,96\% (2000). Suzano adquiriu a condição de município por meio de sua emancipação de Mogi das Cruzes em 8 de dezembro de 1948.

\subsubsection{Aspectos econômicos}

Seu PIB [14] em 2007 era de $\mathrm{R} \$ 5.321,20$ milhões, com PIB per capita de R\$19.797,83. Sua região abriga 563 indústrias e 5.274 empresas. Dessas indústrias, 
12 são de grande porte, que geram 10 mil empregos diretos e 3.327 indiretos, destacando a produção de medicamentos, papel e celulose, máquinas e rolamentos. Ela é umas das 20 cidades que mais arrecadam ICMS no estado de São Paulo.

Tem localização próxima dos portos de Santos e São Sebastião, aeroportos de Congonhas e Cumbica, além de cidades e regiões economicamente fortes como Vale do Paraíba, Grande ABC, capital e Guarulhos. Possui duas ferrovias que contribuem para o desenvolvimento da região do Alto Tietê. Pode ser acessado por importantes rodovias, como Ayrton Senna da Silva, Índio Tibiriçá (SP-31) e Henrique Eroles (SP-66), e através de linha férrea pela Companhia Paulista de Trens Metropolitanos (CPTM).

Pela figura 25 abaixo podemos verificar sua localização dentro da região metropolitana de São Paulo

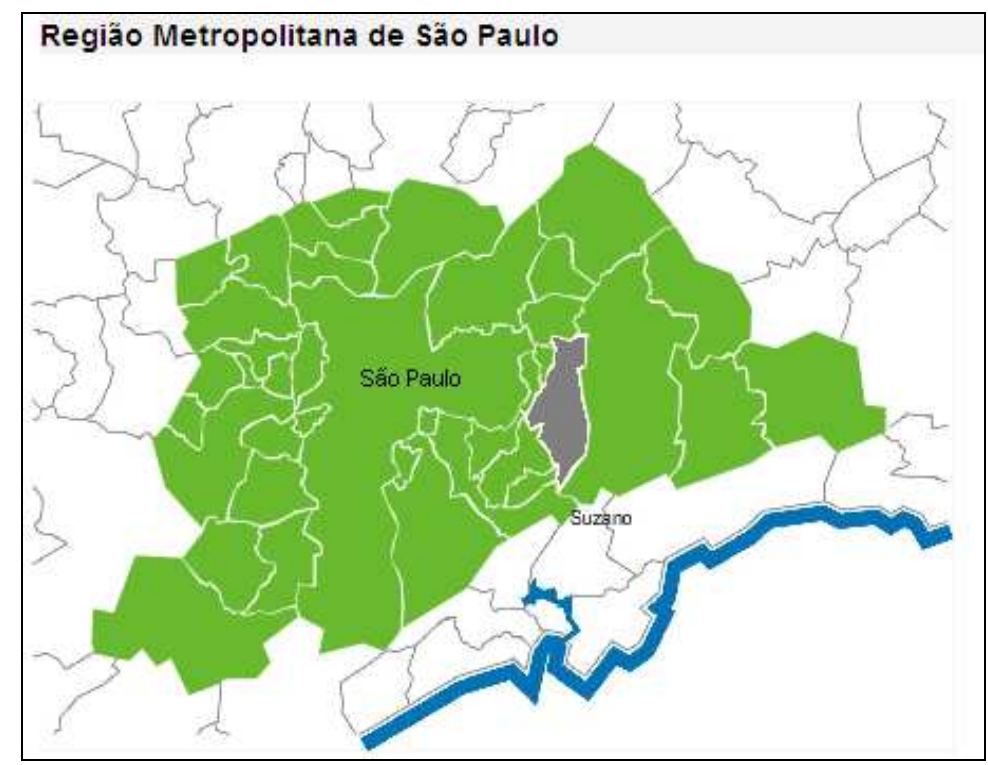

Figura 25 - Região metropolitana de São Paulo e o município de Suzano Fonte: [26] 


\section{Listagem e seleção dos recursos}

A listagem dos recursos energéticos visa identificar todos os que são passíveis de uso ao longo do horizonte de planejamento, independente de características tecnológica e econômica ou de sua aceitação pela sociedade ou especialistas. Para este trabalho, foram listados os Recursos Energéticos do Lado da Oferta - RELOs. Os RELOs são caracterizados, na metodologia do PIR, tanto a fonte como a tecnologia.

A energia utilizada numa indústria de celulose é gerada por diversas fontes, como podemos verificar pela figura 26 e tabela 13.

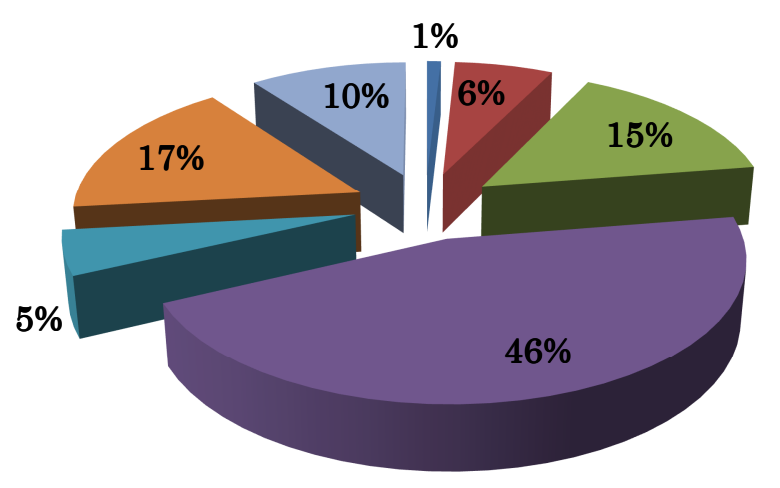

- Carvão Vapor

- Gás Natural

- Lenha

- Lixívia

- Óleo Combustível

- Eletricidade

Outras

Figura 26 - Matriz energética do setor em 2009

Fonte: [11] 
Tabela 13 - Consumo de energia direta e indireta (GJ) no setor de papel e celulose

\begin{tabular}{|c|c|c|}
\hline Energia térmica não renovável & 2009 & 2010 \\
\hline Gás natural & $82.210 .313,80$ & $93.518 .278,60$ \\
\hline Óleo diesel & $2.749 .959,90$ & $2.065 .358,10$ \\
\hline Carvão mineral & $4.951 .165,10$ & 4.721.470,20 \\
\hline Óleos combustíveis & $20.226 .590,60$ & $20.789 .189,30$ \\
\hline Subtotal térmica renovável & $110.138 .029,40$ & $121.094 .292,20$ \\
\hline Energia térmica renovável & 2009 & 2010 \\
\hline Licor Preto & 201.639.651,10 & 216.622.133,90 \\
\hline Biomassa florestal & $59.666 .741,70$ & $56.939 .449,12$ \\
\hline Tall oil & $24.059,00$ & \\
\hline Lenha & $2.756 .434,40$ & $2.387 .872,40$ \\
\hline Subtotal energia térmica renovável & $264.084 .886,20$ & $275.949 .455,40$ \\
\hline Total de energia térmica & $374.224 .915,60$ & $397.043 .747,60$ \\
\hline Energia elétrica gerada & $21.184 .103,80$ & $22,846.554,9$ \\
\hline De origem na queima de combustível renovável & $89,40 \%$ & $90,30 \%$ \\
\hline De origem na queima de combustível não renovável & $10,60 \%$ & $9,70 \%$ \\
\hline Energia elétrica consumida & $34.902 .006,20$ & $37.210 .352,20$ \\
\hline Energia elétrica vendida & $123.155,90$ & $154.009,20$ \\
\hline Total de energia elétrica comprada & $13.717 .902,40$ & $14.363 .797,20$ \\
\hline
\end{tabular}

Fonte: [40][2010]

Além das tecnologias tradicionais, tecnologias mais eficientes para produção de eletricidade a partir de biomassa vêm sendo desenvolvidas em vários países. Uma dessas tecnologias é a gaseificação de biomassa, que também é tema desta dissertação de mestrado.

\subsection{Gaseificação de biomassa}

Pode-se gerar eletricidade através da biomassa de três formas básicas: combustão direta, gaseificação e pirólise. Destas, as duas últimas são mais complexas, possuem maior rendimento e poluem menos. A gaseificação é a combustão parcial de resíduos sólidos para gerar um gás combustível que contenha monóxido de carbono, hidrogênio e hidrocarbonetos gasosos. Os gases produzidos 
possuem muitas aplicações, tais como em motores de combustão interna, turbinas a gás, gás de síntese e, futuramente, células de combustível, o que o torna versátil quanto ao uso do combustível gerado.

É uma tecnologia conhecida há mais de um século, utilizada principalmente durante a Segunda Guerra Mundial, mas que caiu no esquecimento logo após o término da guerra devido ao baixo preço do petróleo. Só após a crise do petróleo seu interesse foi renovado, que sofreu novo golpe durante o final da década de 1980 e início de 1990 com a nova queda do preço do petróleo. No final da década 1990, devido, agora, a maior importância a questões ambientais, as pesquisas foram retomadas.

Existem diferentes tipos de gaseificadores baseados em seu formato e tipo de combustível. Gaseificadores portáteis são os mais indicados para veículos automotivos, enquanto que os estacionários são amplamente utilizados na área rural de países desenvolvidos. É uma tecnologia mais limpa, já que traz impactos positivos ao meio ambiente, das quais pode ser destacada a absorção do carbono da atmosfera, trazendo um balanço neutro do carbono durante o processo de produção de energia elétrica e contribuindo para a redução do efeito estufa.

\subsubsection{Histórico}

A história da gaseificação data por volta do século XVII. Desde a concepção da ideia, a gaseificação tem passado por várias fases de desenvolvimento. 0 cronograma do desenvolvimento da tecnologia segue abaixo:

1669 Thomas Shirley conduziu experiências rudimentares com hidrogênio carbonado.

1788 Robert Garder obteve a primeira patente com relação à gaseificação.

1792 Primeiro uso confirmado do gás. Mordoc usou o gás gerado do carvão para 
iluminar os quartos de sua casa. Desde então, por vários anos o gás de carvão tem sido usado para cozinhar e aquecer.

1812 Desenvolvido o primeiro gaseificador usando óleo como combustível.

1840 Primeiro gaseificador comercial usado, produzido na França, por Ebelman.

1861 Grande salto tecnológico com a introdução do gaseificador da Siemens. Esse gaseificador foi considerado a primeira unidade a funcionar com êxito.

1900 Primeiro gaseificador de 600hp exibido em Paris. Depois, motores acima de $5400 \mathrm{hp}$ foram postos em serviço.

A Alemanha nazista acelerou os esforços para converter os veículos existentes em veículos movidos a gás (figura 27) como parte do plano nacional de segurança e independência dos óleos importados.

Começa o desenvolvimento de pequenos carros e gaseificadores portáteis. A Grã-Bretanha e o governo francês sentiram que carros movidos a gás de 1930 carvão são mais vantajosos em suas colônias, onde o suprimento de gasolina era escasso e a madeira prontamente disponível poderia ser convertido em carvão.

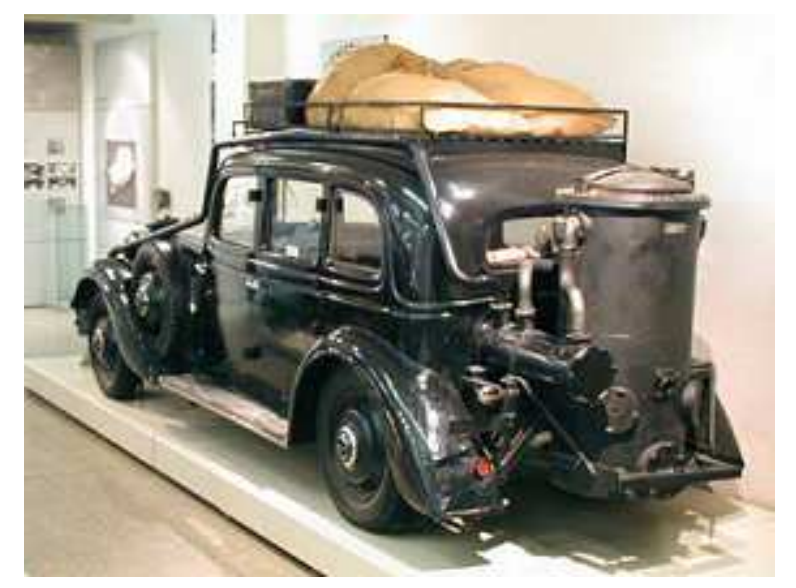

Figura 27 - Automóvel movido a biomassa

Mais de 25.0000 veículos foram registrados na Suécia, 90\% deles foram 1939 convertidos em veículos movidos a gás. Quase todos os tratores eram operados a gás. $40 \%$ do combustível utilizado era madeira e restos de carvão.

Pós

1945

Depois do fim da Segunda Guerra Mundial, com abundância de gasolina e diesel disponível a baixos custos, a tecnologia de gaseificação perdeu sua glória e importância. 
1950- Durante essas décadas, a gaseificação se tornou "uma tecnologia esquecida". 1970 Muitos governos na Europa sentiam que o consumo da madeira nas taxas atuais iria reduzir as florestas, criando severos problemas ambientais.

19731984

Mudanças da política comercial do petróleo fazem que sejam retomadas as pesquisa na área da gaseificação.

Pós Final da década de 1980 e início de 1990, devido à queda do preço do petróleo 1984 e às descobertas de novas reservas, as pesquisas sofrem um novo refluxo.

Pós Final da década de 1990 e começo do século XXI, problemas relativos à 1990

questão ambiental e maior preocupação incentivam a retomada da pesquisa em processos de gaseificação utilizando combustíveis renováveis.

\subsubsection{Aspectos termodinâmicos e químicos da gaseificação}

A gaseificação é um processo complexo, durante o qual o combustível passa pelas seguintes etapas:

- Oxidação da biomassa por um agente gaseificador, normalmente oxigênio ou ar;

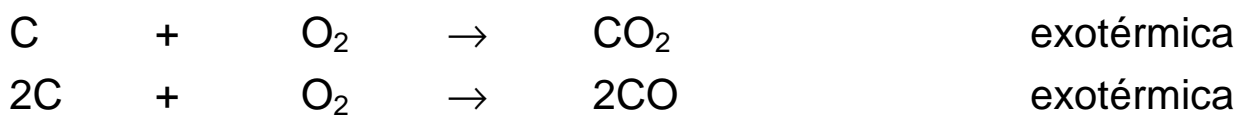

- Aquecimento da biomassa e evaporação da umidade;

- Pirólise através do aumento da temperatura; neste processo resulta da transformação do alcatrão e produtos gasosos;

- Redução dos componentes gasosos produzidos durante as etapas anteriores; as principais reações seguem abaixo:

$\begin{array}{llllll}\mathrm{C}+\mathrm{H}_{2} \mathrm{O} & \rightarrow & \mathrm{CO}+\mathrm{H}_{2} & \text { endotérmica } \\ \mathrm{C}+\mathrm{CO}_{2} \rightarrow & 2 \mathrm{CO} & & \text { endotérmica } \\ \mathrm{C}+\mathrm{H}_{2} \rightarrow & \mathrm{CH}_{4} & & \text { exotérmica } \\ \mathrm{CO}+\mathrm{H}_{2} \mathrm{O} & \rightarrow & \mathrm{CO}_{2}+\mathrm{H}_{2} & \text { exotérmica }\end{array}$


As reações exotérmicas fornecem energia para as reações endotérmicas na forma de calor. Quando um gaseificador está funcionando em pressão atmosférica com ar como oxidante, os produtos finais do processo de gaseificação são gases de baixo poder calorífico, que normalmente contêm $10 \%$ de $\mathrm{CO}_{2}, 20 \%$ de $\mathrm{CO}, 15 \% \mathrm{H}_{2}$ e $2 \%$ de $\mathrm{CH}_{4}$, sendo o resto $\mathrm{N}_{2}$, coque e componentes inertes, ácidos pirolenhosos (essa composição pode variar de acordo com o tipo de combustível e condições de operação, a figura 28 mostra um composição típica deste gás combustível).

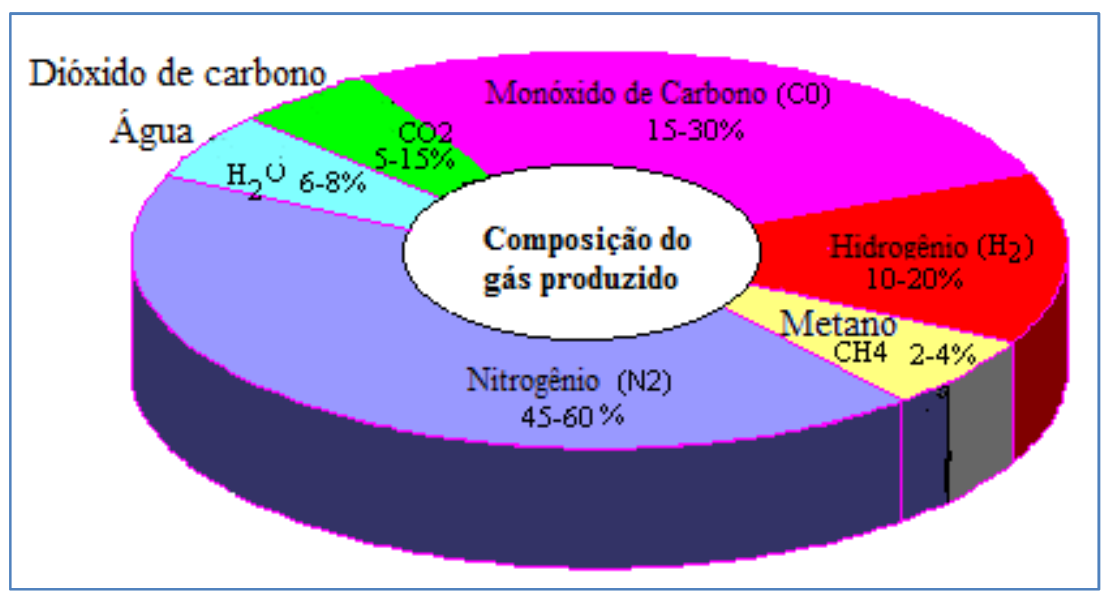

Figura 28 - Composição do gás combustível

Devido ao nitrogênio do ar de entrada, esse gás de baixo poder calórico tem um conteúdo energético de aproximadamente $5600 \mathrm{KJ} / \mathrm{m}^{3}$. O funcionamento dos gaseificadores refinados a ar é bastante estável, barato e seguro, produzindo uma quantidade de gás constante em uma ampla gama de taxas de ar de entrada. Quando se usa oxigênio puro como oxidante em vez do ar, pode-se produzir um gás com poder calorífico médio, com conteúdo energético de aproximadamente 11.200 $\mathrm{KJ} / \mathrm{m}^{3}$.

A maneira usual de classificação dos diversos tipos disponíveis de gaseificadores é feita em função do comportamento do leito da matéria a ser gaseificada. Uma subdivisão pode ser feita em função do movimento relativo do insumo, do agente oxidante e dos gases produzidos. 
A seguir, uma figura mostrando o range de aplicação para diferentes tipos de gaseificação.

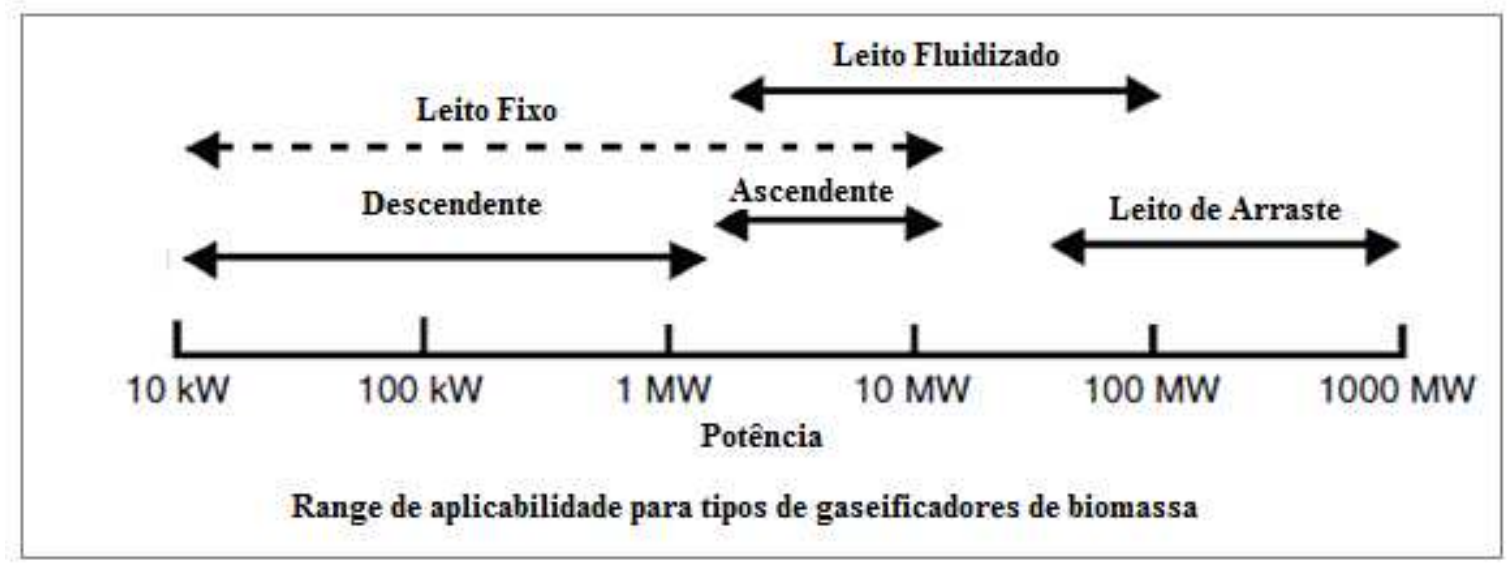

Figura 29 - Faixa de aplicação para diferentes tipos de gaseificadores de biomassa Fonte: [8]adaptado

\subsubsection{Gaseificação em leito fixo}

A gaseificação em leito fixo, na qual a matéria a ser gaseificada só se move por ação da gravidade, é uma técnica adequada para a conversão de quantidades relativamente pequenas de biomassa. Esses gaseificadores são construídos em um leito fixo, onde todo combustível é suportado por uma grelha (também pode ser chamado de leito móvel, pois o combustível se move para baixo). Gaseificadores de leito fixo, de fluxo ascendente, poderiam, em princípio, ser desenvolvidos para maiores capacidades, mas essa não tem sido a tendência. É importante notar que a facilidade com que uma tecnologia pode ser desenvolvida em sua escala (scaling-up) é uma das questões de maior importância em todos os processos de conversão energética da biomassa. Na geração de energia elétrica, gaseificadores de leito fixo têm sido empregados na alimentação de motores de combustão interna, em sistemas de capacidade entre $100 \mathrm{~kW}$ e $10 \mathrm{MW}$. 


\subsubsection{Fluxo ascendente ou contracorrente (Updraft)}

São gaseificadores de tecnologia antiga e relativamente simples. Gaseificadores de fluxo ascendente (o oxidante é introduzido por baixo e o gás produzido sai pela parte superior)(figura 30) produzem gases com pouco particulado, mas com altos teores de alcatrão (10 a 20\%). No caso de aplicações em motores de combustão interna, turbinas ou para geração de gás de síntese, o alcatrão deverá ser removido. Rajadas de ar e vapor são injetadas para manter as cinzas abaixo da temperatura de fusão e facilitar a conversão de carvão. O gás produzido nesse processo tem baixas velocidade e temperatura. A baixa temperatura de operação cria uma quantidade considerável de óleo condensado e alcatrão no gás produzido. Entretanto, o efeito filtrante do leito e a baixa velocidade de vapor produzem um gás com baixa concentração de partículas sólidas. Requer uma grande, densa e quantidade uniforme de combustível.

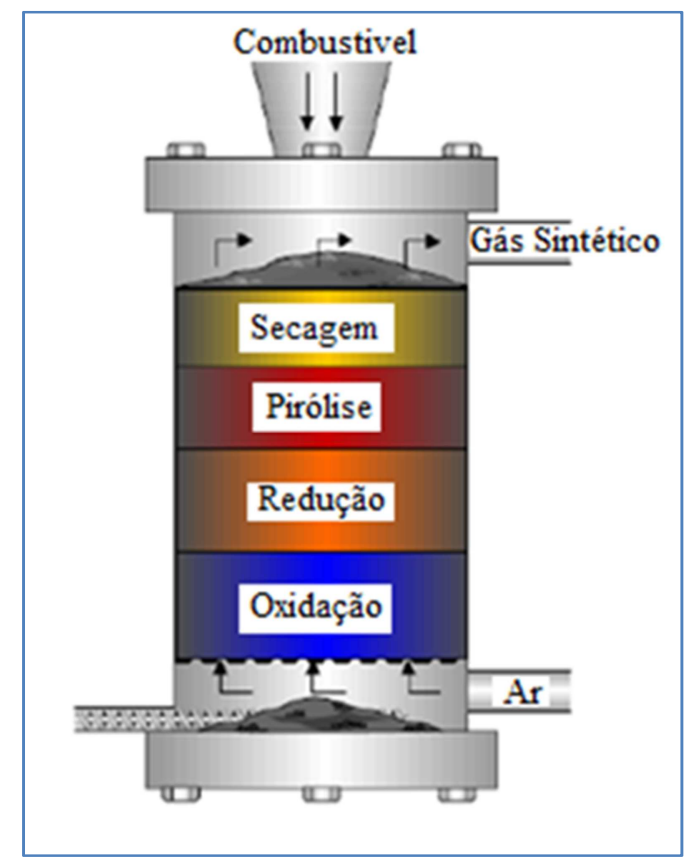

Figura 30 - Gaseificador fluxo ascendente

Fonte: [62] [2008]adaptado 


\subsubsection{Fluxo descendente ou co-correntes (Downdraft)}

Gaseificadores de fluxo descendente (oxidante e gás produzido fluem para baixo) (figura 31) produzem gases com baixos teores de alcatrão e de material particulado; exigem combustíveis com baixa umidade. $\mathrm{O}$ baixo rendimento, a dificuldade de manuseio e as cinzas geradas são problemas comuns em pequenos gaseificadores descendentes. Produzem gases com temperaturas elevadas, caso esse calor não seja aproveitado ele é perdido. É mais indicado para motores a combustão interna do que gaseificadores ascendentes. Ele foi largamente utilizado durante a Segunda Guerra Mundial em veículos automotivos.

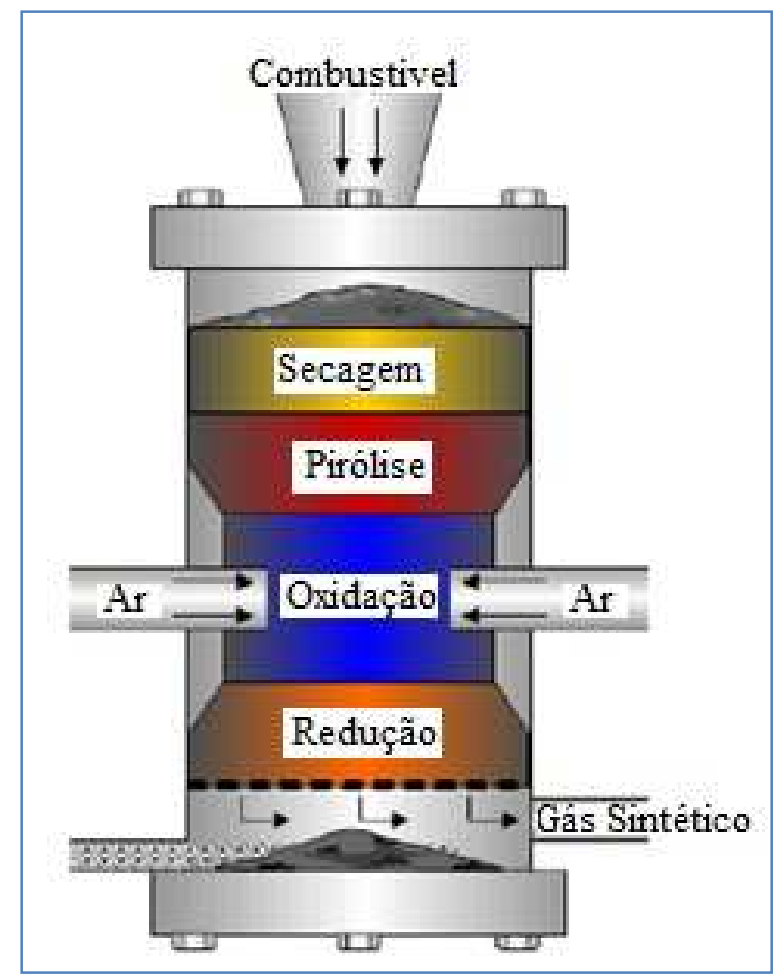

Figura 31 - Gaseificador leito descendente

Fonte: [62] [2008] adaptado 


\subsubsection{Gaseificação de leito fluidizado (Circulating fluidesed bed-CFB)}

Gaseificadores de leito fluidizado têm sido utilizados na conversão termoquímica da turfa já há muitos anos, mas ainda não existe muita experiência na conversão da biomassa, pelo menos em grande escala. Nos equipamentos desse tipo, emprega-se um material como meio fluidizante (figura 32), que arrasta consigo a biomassa, aumentando o contato desta com o elemento oxidante e, consequentemente, aumentando as taxas de reação.

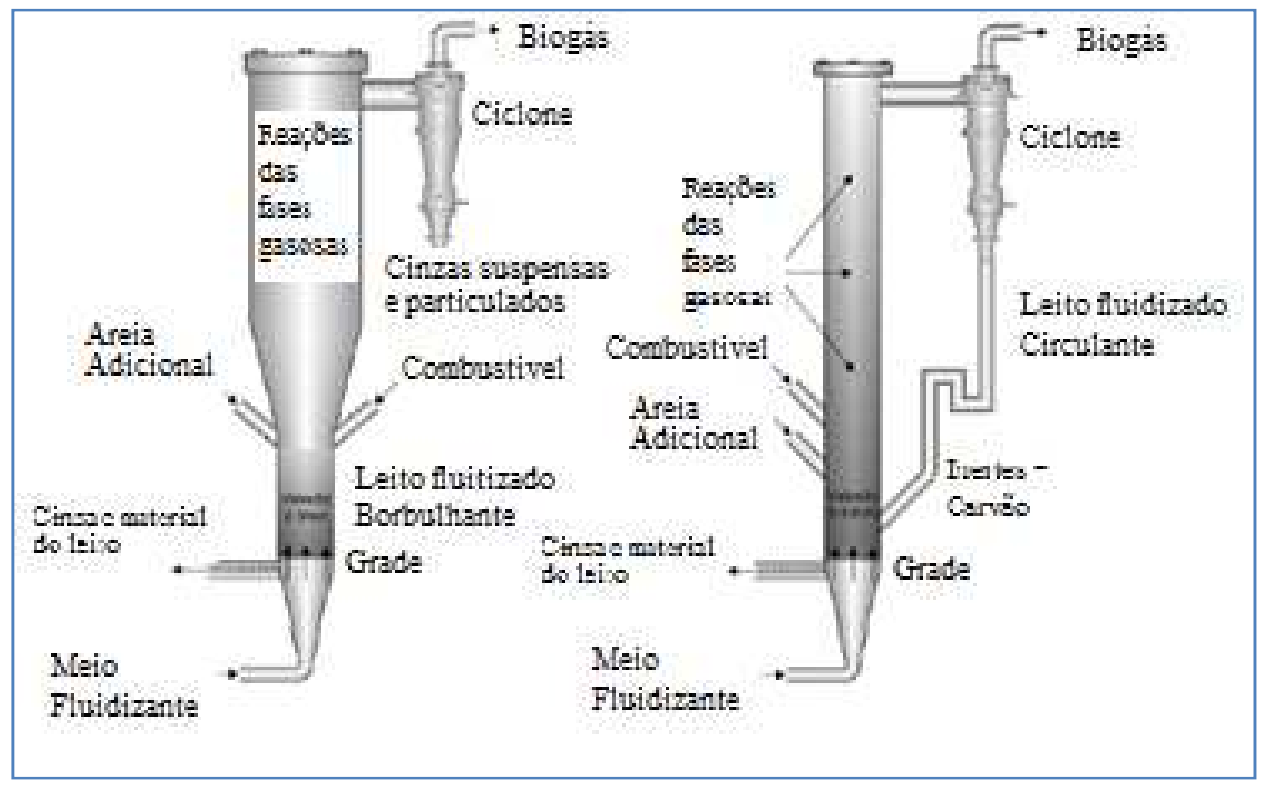

Figura 32 - Gaseificador leito fluidizado

Fonte: [62][2008]adaptado

Gaseificadores de leito fluidizado são mais adequados à conversão de uma maior quantidade de biomassa; sistemas com capacidade entre 10 e 20 toneladas de biomassa por hora já são operacionais.

São também mais flexíveis quanto as características do insumo, podendo ser empregados na conversão de biomassa com mínimas necessidades de processamento anterior à alimentação. Em função dessas vantagens (além do controle mais fácil), é o princípio que tem sido empregado em quase todos os 
projetos de desenvolvimento de sistemas IGCC (sigla em inglês para "gaseificação integrada a ciclos combinados"). Por outro lado, além dos maiores custos operacionais, os problemas de adequação dos gases quanto a sua qualidade tendem a ser maiores. Em função da própria natureza do processo, a quantidade de material particulado arrastada tende a ser maior; um segundo aspecto é que a maior temperatura de saída dos gases permite que os álcalis saiam ainda na fase gasosa, impondo dificuldades adicionais à limpeza.

Há dois modos de fornecer calor: direto e indireto. No fornecimento de calor direto, o calor requerido para a gaseificação vem da combustão do carvão no reator. No modo indireto, o carvão removido do gaseificador é queimado num recipiente separado. A vantagem é que os subprodutos da queima do carvão não se misturam com os produtos da gaseificação.

\subsubsection{Gaseificação de leito de arraste (Entrained Flow)}

Nos gaseificadores de leito de arraste(figura 33), a biomassa seca (ou líquida) é injetada junto com uma quantidade relativamente alta de oxigênio e/ou vapor pressurizado. Esses tipos de gaseificadores foram desenvolvidos para carvão e poucos testes foram realizados com biomassa, sendo que o custo elevado para preparar o combustível e a vida útil do refratário é umas das principais razões [2]. Uma chama turbulenta no topo do gaseificador queima alguma biomassa, provendo grande quantidade de calor, à alta temperatura $\left(1.200\right.$ a $\left.1.500{ }^{\circ} \mathrm{C}\right)$, para rápida conversão da biomassa para um gás de alta qualidade. A cinza funde nas paredes do gaseificador e é eliminada como escória fundida. 


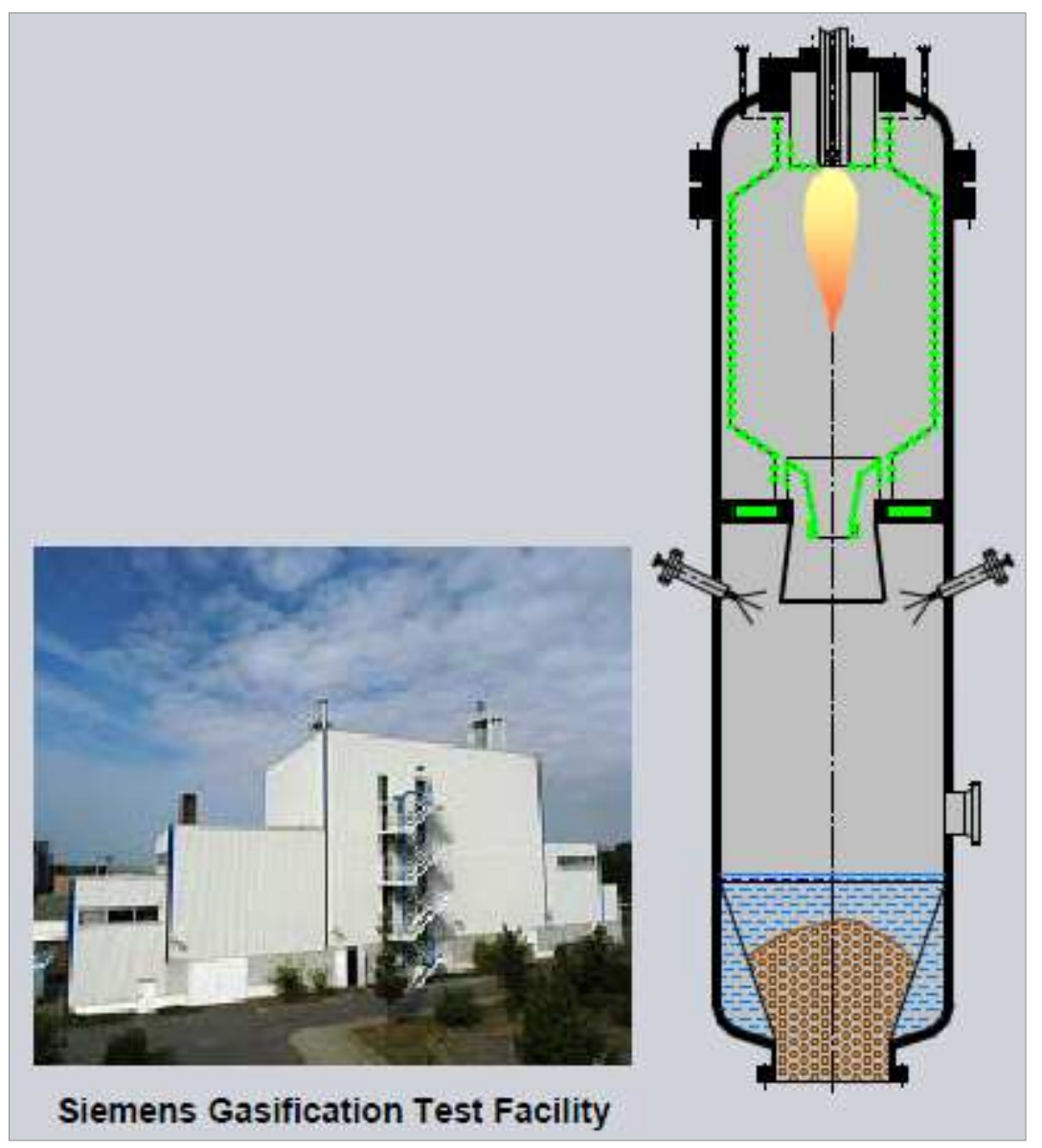

Figura 33 - Gaseificador leito de arraste Fonte: [4]

\subsubsection{Gaseificação do licor negro}

Gaseificadores de licor negro vêm sendo desenvolvidos como tecnologia em substituição às caldeiras Tomlinson (tecnologia que vem sendo utilizada nas caldeiras de recuperação tradicionais existentes), e vários conceitos têm sido propostos. Sérios esforços para a comercialização de dois desses conceitos estão sendo empregados através de iniciativas tipo joint entre indústrias e governos. Os dois são distintos em relação aos conceitos de sua temperatura de operação [1].

Gaseificação à alta temperatura, em desenvolvimento por uma empresa Sueca (Chemrec), possui uma tecnologia similar ao gaseificador de carvão tipo fluxo de arraste. Esse conceito opera sobre elevadas pressões com oxigênio usado como 
oxidante parcial do licor negro. Devido à alta temperatura de operação (950 a $1.000{ }^{\circ} \mathrm{C}$ ), o material inorgânico do licor negro sai como smelt (materia fundente resultante da queima do licor negro). O oxigênio utilizado seria proveniente da mesma fonte de outros processos da fabricação de celulose (como tratamento de efluentes, branqueamento etc.). Foi dado início a uma planta piloto, em 1994, na Suécia [1].

Gaseificação a baixa temperatura, próximas à pressão atmosférica, tem sido desenvolvida por uma empresa americana (Thermochem Recovery International). Esse conceito utiliza o aquecimento indireto do licor negro num gaseificador de leito fluidizado. O gás produzido por esse processo é mais rico em hidrogênio do que o processo à alta temperatura, além de possuir poder calorífero relativamente maior comparado com o processo à alta temperatura. Devido à temperatura moderada dentro do reator (aproximadamente $600^{\circ} \mathrm{C}$ ), o material sai mais sólido do que o smelt. Essa tecnológia vem sendo desenvolvida desde os meados da década de 1980 com suporte do Departamento de Energia dos EUA. Uma unidade piloto foi iniciada no começo dos anos 90[1]. Uma planta em escala comercial estava em processo de construção (2003) na planta de Gergia Pacific em Big Island, Virginia.

Com a gaseificação, o processo de recuperação foi modificado em relação ao convencional utilizado sobre o de caldeiras tipo Tomlinson. Essencialmente, todo sódio e enxofre saem junto com o smelt nas caldeiras tradicionais. Na gaseificação, entre $50 \%$ (alta temperatura) ou $90 \%$ (baixa temperatura) do enxofre sai na forma gasosa $\left(\mathrm{H}_{2} \mathrm{~S}\right)$, junto com o gás combustível gerado. Esse gás poderia ser reaproveitado na própria planta de celulose, baixando o custo de utilização de madeira. Uma consequência negativa de seu uso no processo seria o aumento da carga na caustificação e do forno de cal. No caso do processo à baixa temperatura, 
seria necessário um aumento em torno de $44 \%$, enquanto que no processo de alta temperatura, $16 \%[1]$.

A seguir, configuração típica de uma caldeira tradicional de sistema Tomlinson:

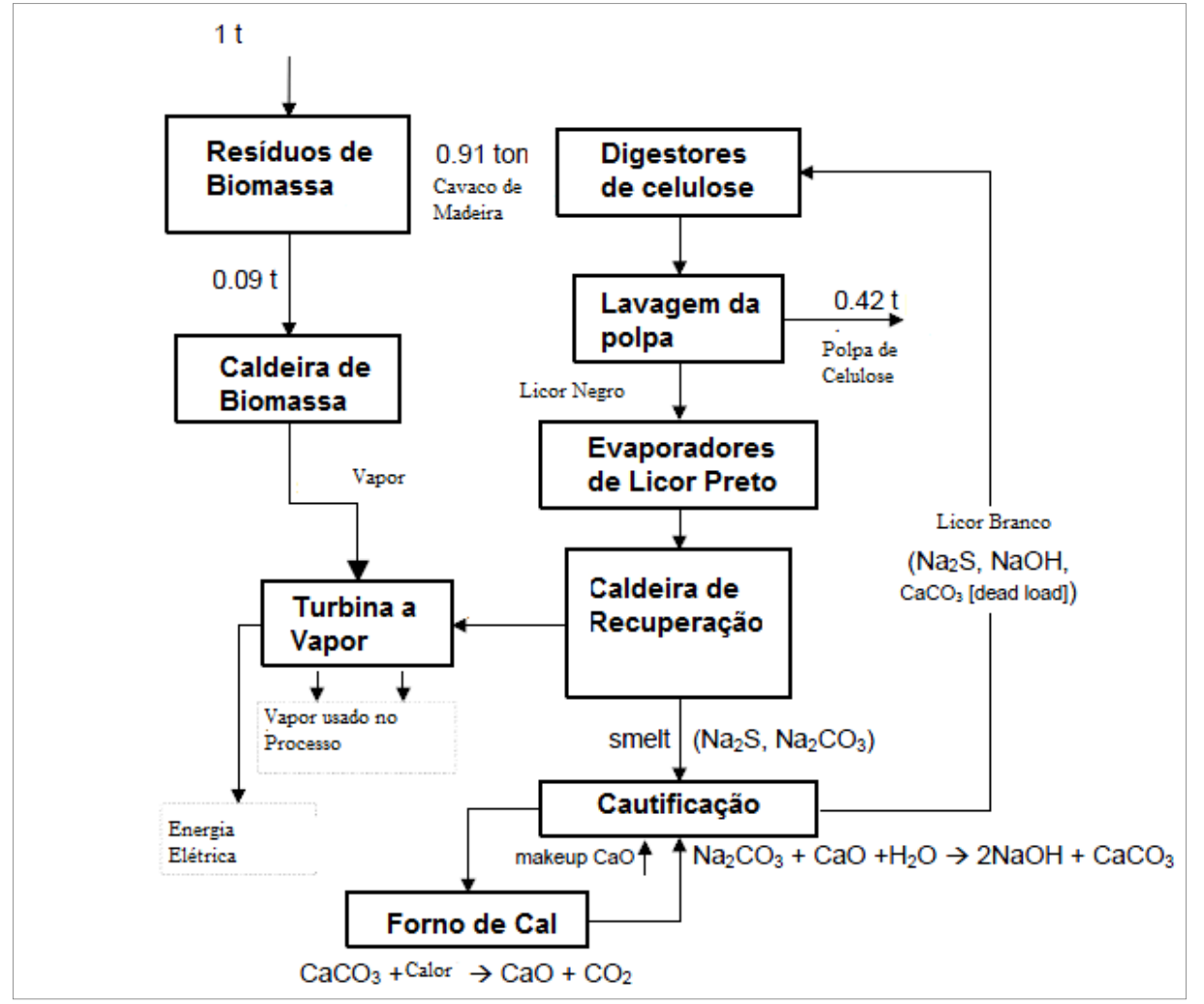

Figura 34 - Esquema simplificado do processo Kraft usado em um processo tradicional Fonte: [1] 2003

E agora na figura abaixo, utilizando um gaseificador de licor negro: 


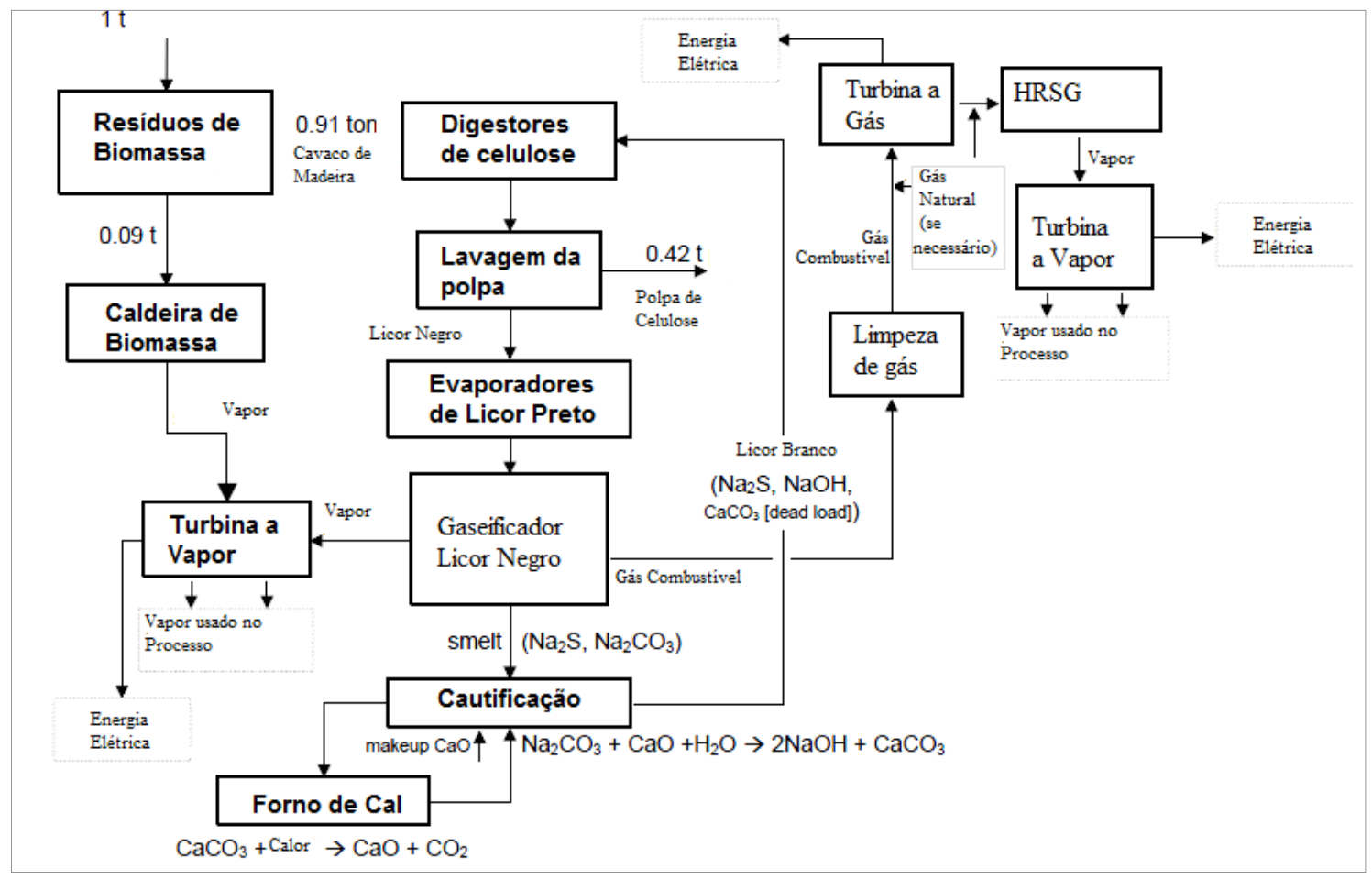

Figura 35 - Esquema de um BLGCC

A seguir (figura 36) são apresentados os custos de geração de eletricidade das configurações BLGCC, consideradas as mais eficientes:

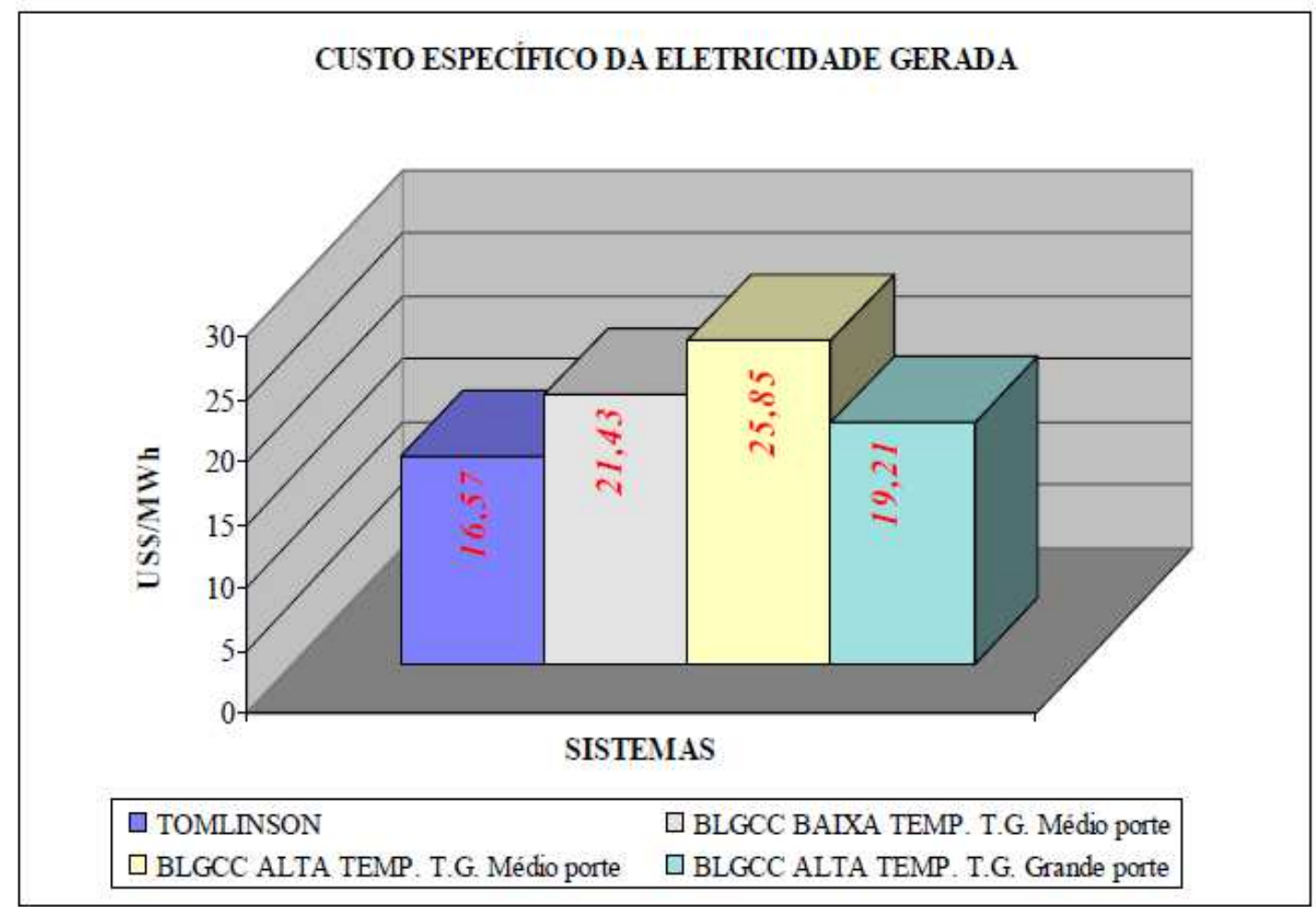

Figura 36 - Custos específicos de eletricidade

Fonte: [7] 
A partir dos resultados apresentados na figura 36, pode-se observar que, a configuração BLGCC de Alta Temperatura com Turbina a Gás de Grande Porte apresenta custo de geração mais próximo ao da situação tradicional, usando sistema Tomlinson. Isso acontece porque o sistema BLGCC gera uma quantidade maior de eletricidade, embora apresente custo capital mais elevado.

Com relação às emissões atmosféricas, não há dados reais sobre as emissões em sistemas BLGCC. Para isso, foram feitas estimativas [7] baseadas em sistemas integrados de gaseificação de carvão em ciclo combinado a gás natural denominado Integrated Gasifier Systems/Combined Cycle (IGCC).Os resultados podem ser vistos na tabela 14 a seguir. Para efeito de comparação, as emissões consideradas são provenientes das emissões do forno de cal e caldeira de biomassa [7].

Tabela 14 - Emissões totais

\begin{tabular}{|c|c|c|c|c|}
\hline \multicolumn{5}{|c|}{ Emissões Totais (lb/MWh) } \\
\hline Poluentes & Tomlinson & $\begin{array}{c}\text { Baixa Temp. } \\
\text { Turbina Médio } \\
\text { Porte }\end{array}$ & $\begin{array}{c}\text { Alta Temp. } \\
\text { Turbina } \\
\text { Médio } \\
\text { Porte }\end{array}$ & $\begin{array}{c}\text { Alta Temp. } \\
\text { Turbina } \\
\text { Grande } \\
\text { Porte }\end{array}$ \\
\hline $\mathrm{CO} 2$ & 5879 & 3278 & 3258 & 1985 \\
\hline SO2 & 0,81 & 0,25 & 0,27 & 0,11 \\
\hline NOx & 4,92 & 1,00 & 1,80 & 1,14 \\
\hline $\mathrm{CO}$ & 4,51 & 94,00 & 2,16 & 0,90 \\
\hline VOC & 0,37 & 2,19 & 0,07 & 0,03 \\
\hline MP & 1,34 & 0,07 & 0,24 & 0,12 \\
\hline TRS (S reduzido) & 0,09 & 0,26 & 0,01 & 0,00 \\
\hline
\end{tabular}

Fonte: [7][2006]

\subsubsection{Situação atual da gaseificação no mundo}

Atualmente, há mais plantas de gaseificação de biomassa para geração de biocombustíveis do que para geração de energia elétrica [21]. 
Unidades de gaseificação em leito fluidizado pressurizado interromperam a operação [7] como a de Maui, Havaí. Temos também a planta de Värnamo, Suécia, que foi a primeira no mundo a operar em ciclo BIG-GTCC, com capacidade de gerar 6 MWe e 9 MWth; operou entre 1996 e 2000. Atualmente, a União Europeia usa para pesquisas na produção de combustível líquido a partir de biomassa [22].

Entre as plantas que continuam em operação, há [7]:

- Zetweg, Austrália - Capacidade de 10 MWth em operação desde 1997;

- Kymijärvi in Lahti, Finlândia - Capacidade entre 40 a 70 MWth (dependendo da composição e da umidade do combustível em operação desde 1998. É alimentada com biomassa e combustível reciclado (misturados).

- Ruien, Bélgica - Capacidade de 86 MWth. Sua dona é a Electrobel (que participou do projeto Zeltweb). É alimentada com madeira.

- Amer, St. Geertruidenberg, Países Baixos - Capacidade de 83 MW. É alimentada por resíduos de madeira.

- Gussing, Áustria - Capacidade de 2,3 MWe. Iniciou operação em 2001. É alimentada por lascas de madeira.

- Skive, Dinamarca - Capacidade de 20 MWth. Iniciou operação em 2009. É alimentada por lascas de madeira. Utilizada tecnologia da Choren.

Para a geração de biocombustível, há [23]:

- Para a gaseificação de leito de arraste, há dois fabricantes que estão com pesquisas em estágios mais avançados e que têm recebido incentivos significantes dos governos e investidores, com participação de parceiros industriais. Esses fabricantes têm construído plantas de demonstração:

CHOREN: Uma planta de 3 odt/dia está em operação desde 2003 e outra de 200 odt/dia está em fase de testes. Possuem ambição de fazer um scale-up para 3040 
odt/dia entre 2012 e 2013, com grande desenvolvimento na Alemanha. Possui como parceiros Shell, Volkswagen e Daimler.

Range Fuel: Construiu uma planta piloto de 5 odt/dia em 2008, em Denver, e uma de 125 odt/dia na Geórgia para produção de etanol e alcoóis misturados em 2010. Tem planos para construir plantas comerciais de 1.250 otd/dia.

Além disso, existem outros três desenvolvedores de tecnologia concentrados em produzir biocombustível, mas que atualmente estão em estado menos avançado, tais como Person, FZK/KIT e Mitsubishi Heavy Industries. Person e Mitsubishi têm plantas pilotos de menos de 5 odt/dia.

- Para a gaseificação em leito fluidizado, há:

Carbona/Andritz Skive CHP, uma planta que entrou em operação em meados de 2008, usando 100-150 odt/dia de madeira. Há planos para desenvolver tecnologia para a construção de uma planta de 1440 otd/dia que produza biodiesel.

Enerkem's BioSys tem uma planta de 30 otd/dia, em Westbury, que está sendo comissionada e uma planta de 228 odt/dia em construção em Edmonton desde 2009 (ambos no Canadá).

No Brasil, há o projeto WBP SIGAME, que tem a finalidade de demonstrar a viabilidade comercial da produção de eletricidade com tecnologia BIG-GTCC, utilizando biomassa de madeira. Teve início em 1991. Outras unidades de testes foram desenvolvidas por universidades e algumas em pequena escala foram desenvolvidas para gerar energia elétrica para as pequenas comunidades isoladas.

Para os gaseificadores de lixívia, há os seguintes históricos, iniciando à baixa temperatura:

- VTT, Centro de Pesquisa Técnica da Finlândia (final dos anos 1980 e início 
dos anos 1990); testes finalizados em 1992 por problemas econômicos;

- ABB - Asea Brown Boveri (início dos anos 1990), sistema de gaseificação seco; testes finalizados devido a problemas técnicos;

- B\&W - Babcock \& Wilcox (meados dos anos 1990), sistema de gaseificador de leito fluidizante;

- MTCl - Manufacturing and Technology Conversion International (meados dos anos 1980), sistema de gaseificador de leito fluidizante. Após testes em plantas de demonstração, foram construídos dois sistemas em escala industrial na Geógia e em Virgínia;

- KBR - Kellog, Brown \& Root (entre 1998 e 2003), sistema de gaseificador de leito fluidizante. Suspensos devido à mudança de prioridade corporativa.

Para os gaseficadores de alta temperatura, há [7]:

- AST (Atomization suspension technique) Paprican (décadas de 1950 e 1960);

- UCPGC (The University of California pyrolysis-gasification-combustion) Universidade da Califórnia (meados dos anos 1960);

- NTS - gaseificador ciclone sueco (anos 1970);

- Champion-Rockwell - Sistema de gaseificação de sal fundido; testes em escala de laboratório e piloto;

- SKF Steel - planta piloto construída em 1987;

- Ahlstron - planta piloto foi construída (final dos anos 1980 e início dos anos 1990);

- Noell - KRC - sistema pressurizado (meados dos anos 1990);

- Chemrec - em 1991 foi construída a primeira planta industrial em Frovi, na Suécia. Cinco anos mais tarde, outra planta similar foi construída na planta de 
Weyerhaeuser, na Carolina do Norte. Desenvolvido um sistema de maior capacidade e menor pressão que foi instalado, em 2005, na empresa Kappa Kraftliner, em Pitea.

\subsection{Caldeira de recuperação}

A principal fonte geradora de energia, produzida no próprio processo de fabricação da celulose, é resultante da queima do licor negro na caldeira de recuperação. Ela é responsável pela combustão da matéria orgânica do licor preto com maior eficiência térmica possível; fornece calor para produção de vapor. Ao mesmo tempo ocorrem reações de redução dos compostos de enxofre a sulfeto de sódio, e outros sais de sódio se transformam em carbonato de sódio, gerando o Smelt que, ao ser dissolvido com licor branco, forma o licor verde, usado na caustificação.

O licor negro é injetado na fornalha por meio de bicos queimadores situados nas paredes laterais da caldeira.

O calor gerado produz vapor, que serve para diversos outros usos em seu processo produtivo; uma parte alimenta uma turbina a vapor que gera energia elétrica.

Os gases resultantes da queima arrastam partículas de sulfato de sódio e outras partículas; para minimizar perdas e poluição, utilizam-se precipitadores eletrostáticos, nos quais as placas carregadas eletricamente retêm essas partículas.

As caldeiras de recuperação atuais são baseadas na configuração criada por George Tomlinson e foram patenteadas nos anos 1970. A caldeira Tomlinson é o equipamento mais importante e complexo da planta, além de ser o maior, tanto em tamanho quanto em investimento, em uma fábrica de celulose. Ela opera em pressões e temperaturas elevadas, que são valores comuns, na prática, para 
minimizar a corrosão na fornalha e no superaquecedor. São comercializadas e testadas no mundo todo, sendo que várias delas são antigas e tem sua vida útil praticamente chegando ao fim. Na figura 37 podemos ver uma foto de uma caldeira de recuperação.

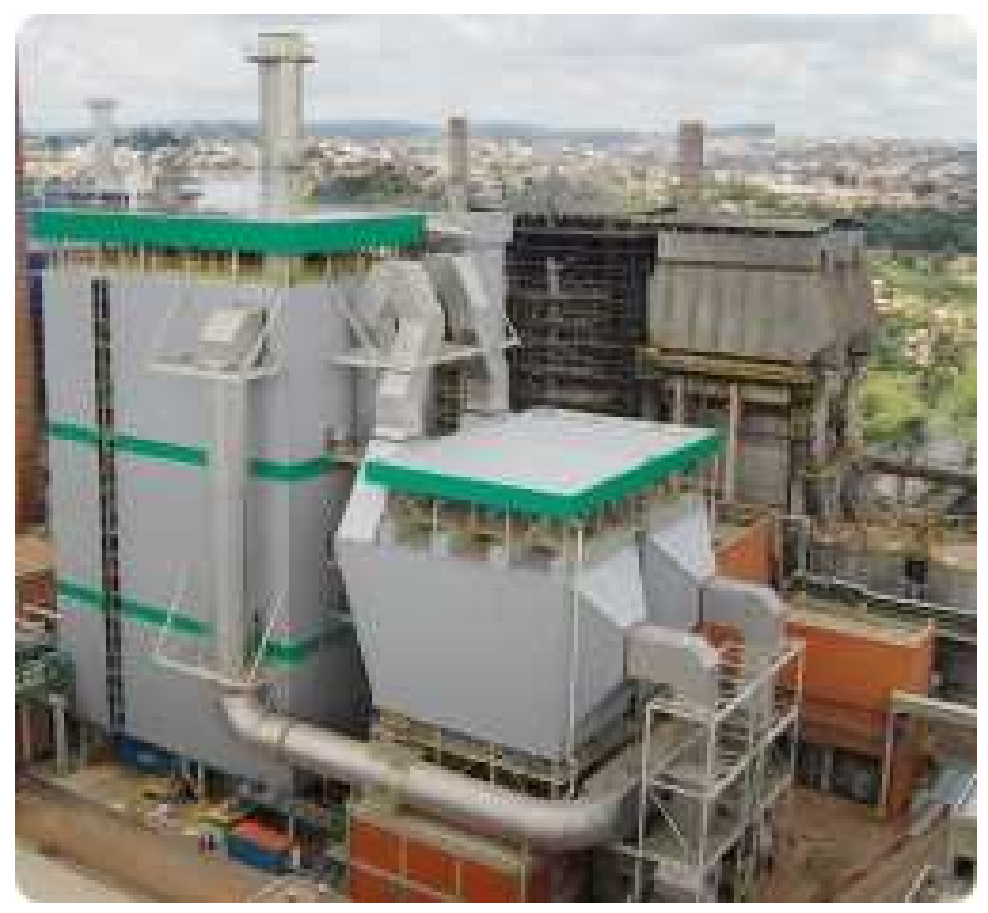

Figura 37 - Caldeira de recuperação

Fonte: [27]

São tecnologias comerciais e utilizadas em várias plantas ao redor do mundo.

\subsection{Caldeira de biomassa}

Uma segunda fonte de energia, também associada ao processo de produção, consiste na queima de resíduos florestais (cascas e galhos de eucalipto) em uma caldeira auxiliar. Trata-se de uma caldeira aquatubular pressurizada ou de tiragem balanceada que utiliza a queima direta do combustível para gerar vapor. Pode utilizar grelha rotativa ou fixa. São tecnologias comerciais e utilizadas em várias plantas ao redor do mundo. Abaixo temos uma foto de uma caldeira de biomassa. 


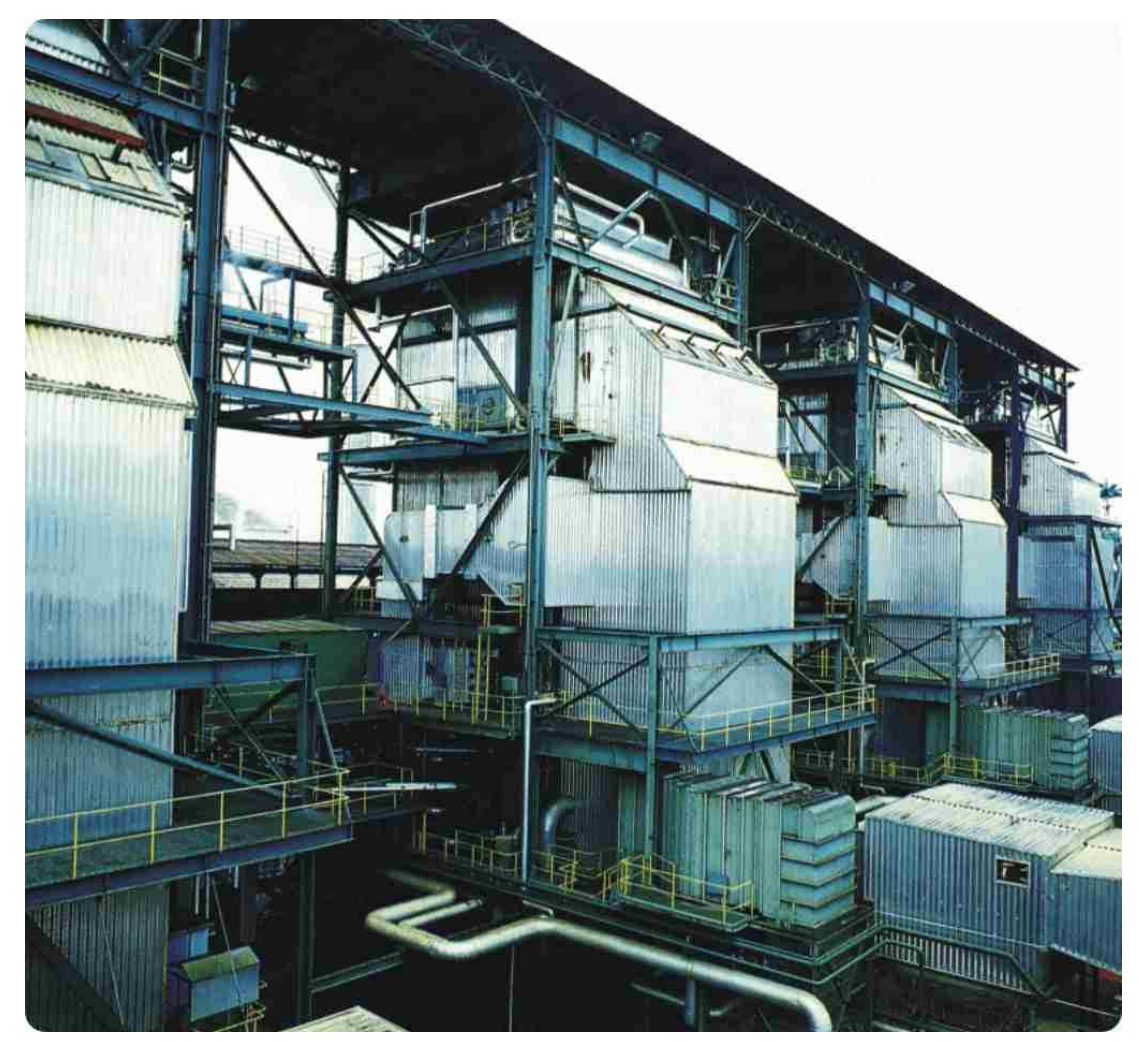

Figura 38 - Caldeira de biomassa

Fonte: [27]

As cinzas resultantes da queima de biomassa podem ser utilizadas como adubo na plantação de árvores.

\subsection{Caldeira a Óleo/Gás Natural}

Outra fonte de energia são as caldeiras a óleo ou gás natural. Tradicionalmente, utilizava-se o óleo combustível, mas, com o desenvolvimento de redes de transporte de gás natural (gasodutos), oportunidades de utilizar esse combustível têm aparecido.

O uso de gás natural traz as seguintes vantagens [41]:

- Não é necessário manipulações ou preparação antes da combustão;

- É facilmente miscível ao ar, reduzindo o excesso de ar necessário para 
assegurar a combustão completa;

- O controle da atmosfera da fornalha é simples;

- Facilidade para deslocamento e manipulação, bastando uma válvula para regular com precisão as vazões de ar e gás.

- Praticamente não contêm impurezas. Seus produtos de combustão têm baixos níveis de poluição, com teor de enxofre inferior ao de carvões e óleos combustíveis. Por não depositar resíduos, simplifica e diminui os custos operacionais e de manutenção;

- Seu estado gasoso permite várias configurações e tipos de queimadores, além de grande flexibilidade no seu funcionamento.

Como desvantagem podem ser citadas [41]:

- Sua densidade é muito menor que a dos combustíveis sólidos e líquidos, levando a dificuldades de armazenamento e de transporte;

- Seus produtos de combustão possuem grande quantidade de vapor d'água, sendo assim, o calor específico dos produtos é alto, as temperaturas de combustão são mais baixas e apresenta problemas devido à condensação do vapor;

- É muito sensível à variação de consumo de ar e combustível, permitindo modificar a carga da fornalha instantaneamente. Entretanto, uma interrupção da alimentação provoca a extinção da chama, aumentando o perigo de explosão ao recomeçar a alimentação.

Elas são caldeiras do tipo aquatubular, tecnologia comercial e utilizada em várias plantas ao redor do mundo.Na figura a seguir temos uma foto de uma caldeira tradicional de óleo/gás. 


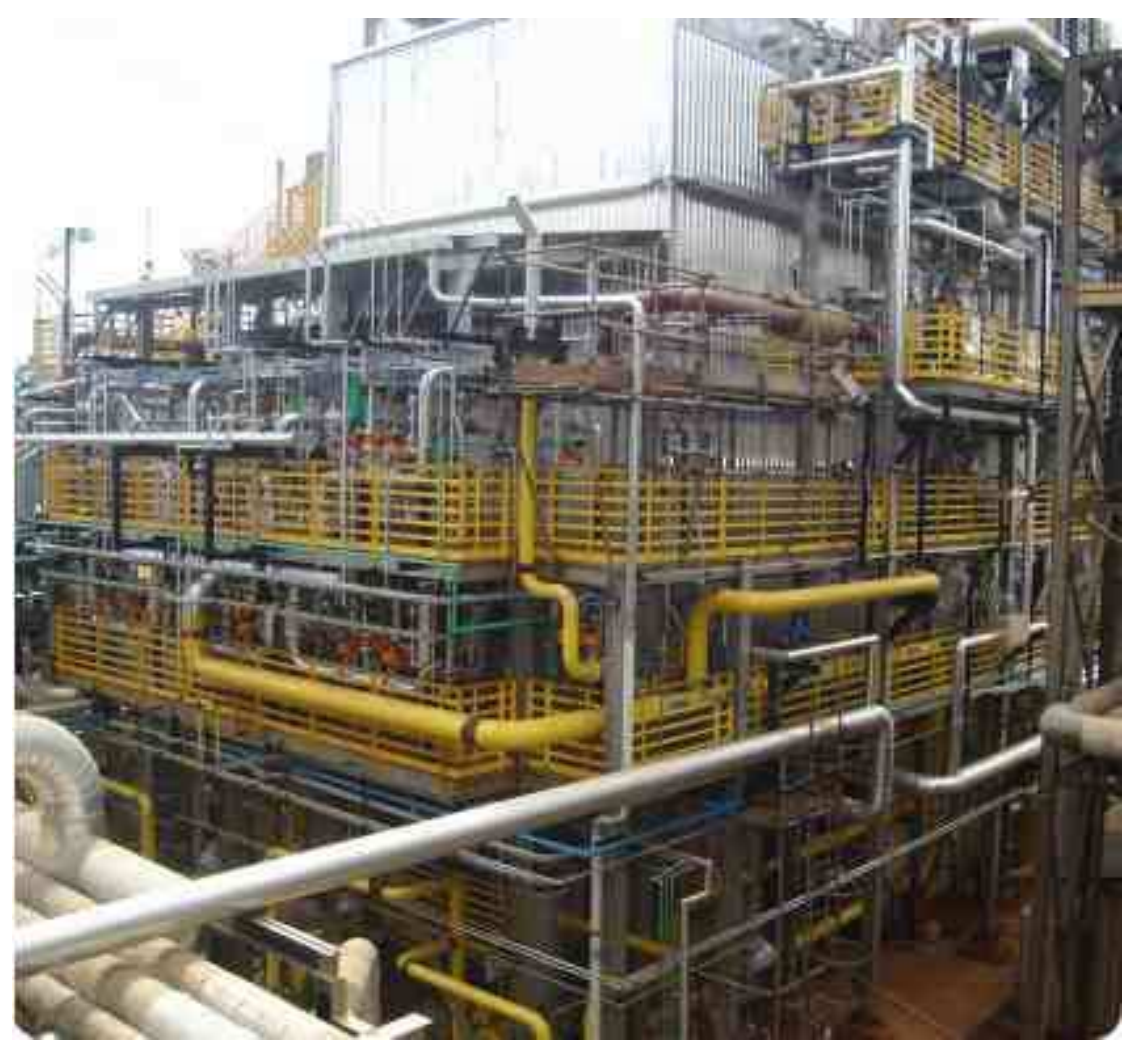

Figura 39 - Caldeira de tradicional (óleo/gás)

Fonte: [27]

\subsection{Hidrelétrica}

Outra fonte de energia vem do complexo formado pelas usinas hidroelétricas Amador Aguiar I e II (figura 40), através do sistema interligado brasileiro. Essas usinas são controladas pelo Consórcio Capim Branco Energia (CCBE), formado pela Companhia Vale do Rio Doce (CVRD), com 48,42\%, pela Companhia Energética de Minas Gerais (Cemig), com 21,05\%, pela Suzano Papel e Celulose $(17,89 \%)$ e pela Votorantim Metais (12,63\%) [51].

O complexo formado por duas usinas se localizam no rio Araguari, entre os municípios de Indianópolis, Araguari e Uberlândia. 


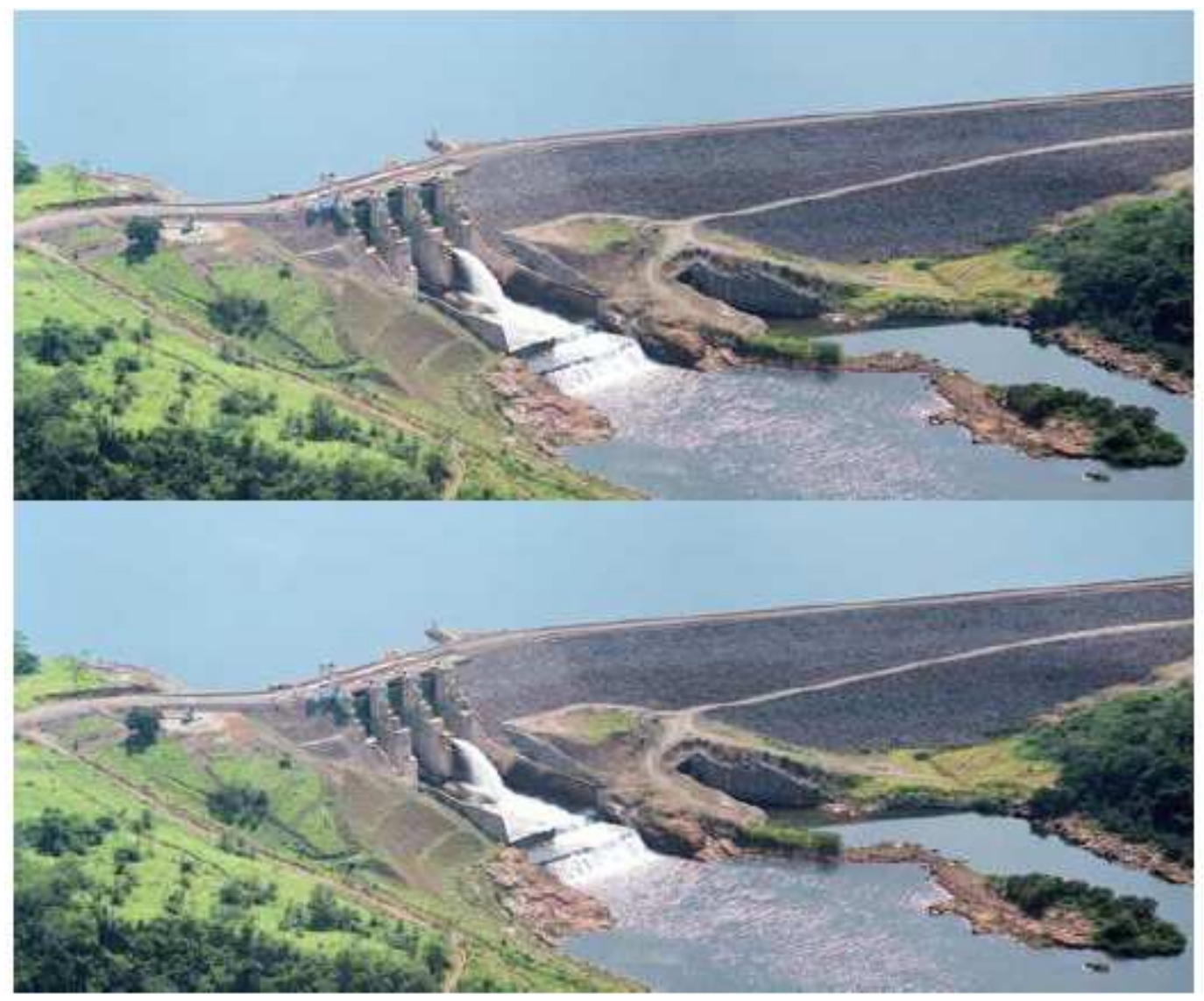

Figura 40 - Usinas Amador Aguiar I (superior) e Amador Aguiar II (inferior) Fonte: [51]

A demanda da Suzano Papel e Celulose fica em torno 49 MW. Essa energia passa por transformadores de 88/11 kV, $12.500 \mathrm{kVA}$ e por um transformador de 88/11 kV, 20.000 kVA. Além disso, há na estação um transformador de 88/11 kV, 10.000 kVA. Essa energia é distribuída na fábrica com uma tensão de 11 kV [50].

Abaixo podemos ver o esquema elétrico mostrando de onde se origina a energia consumida no processo. 


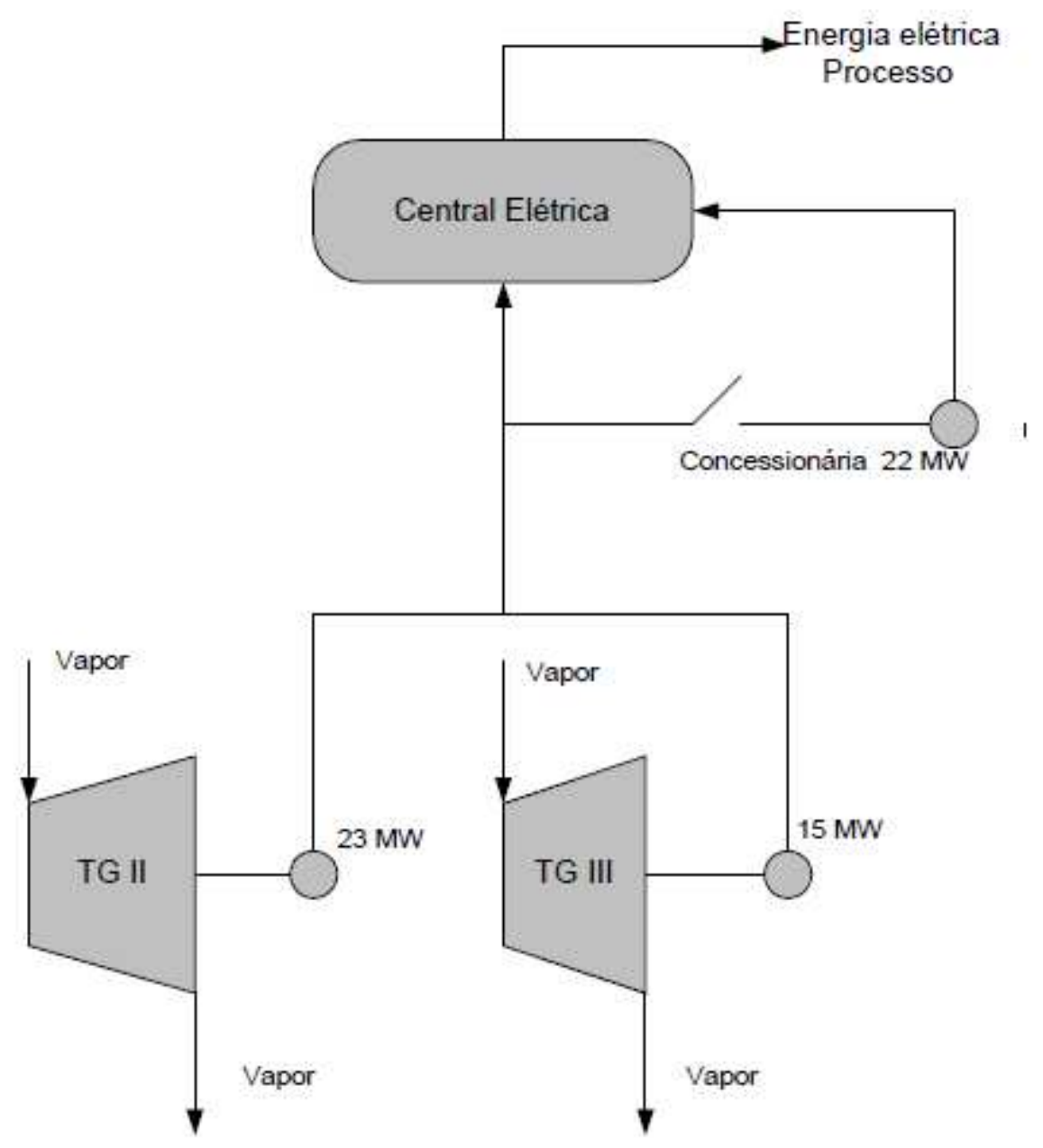

Figura 41 - Processo de geração e distribuição de energia elétrica Fonte: [50] 


\section{Cômputo e Valoração do Potencial Completo (CVPC)}

Neste capítulo, será identificado, dentro de cada dimensão analisada, o comportamento de cada um dos recursos energéticos. Valoração nada mais é do que dar "valores" aos atributos e subatributos de cada dimensão, que podem ser numéricos ou uma descrição.

Segue uma descrição dos subatributos baseados na dissertação de doutorado de Ricardo Lacerda Baitelo [6]. Entretanto, para este trabalho, a valoração foi baseada em planilhas anteriores a esta dissertação de mestrado.

\subsection{Dimensão técnico-econômica}

A valoração nesta dimensão vale-se de diferentes índices técnicos relacionados a equipamentos e empreendimentos energéticos, que podem estar disponíveis ou que podem ser obtidos por cálculos de diferentes metodologias. O objetivo principal é o cálculo de potenciais energéticos completos dos recursos analisados, utilizando diferentes parâmetros, dentre eles: custos de instalação, de manutenção e operação, vida útil, fator de potência, entre outros. Esses atributos cobrem as três principais áreas desta análise, que são: economicidade, capacidade energética e fatores técnicos - como é possível visualizar na figura a seguir. 


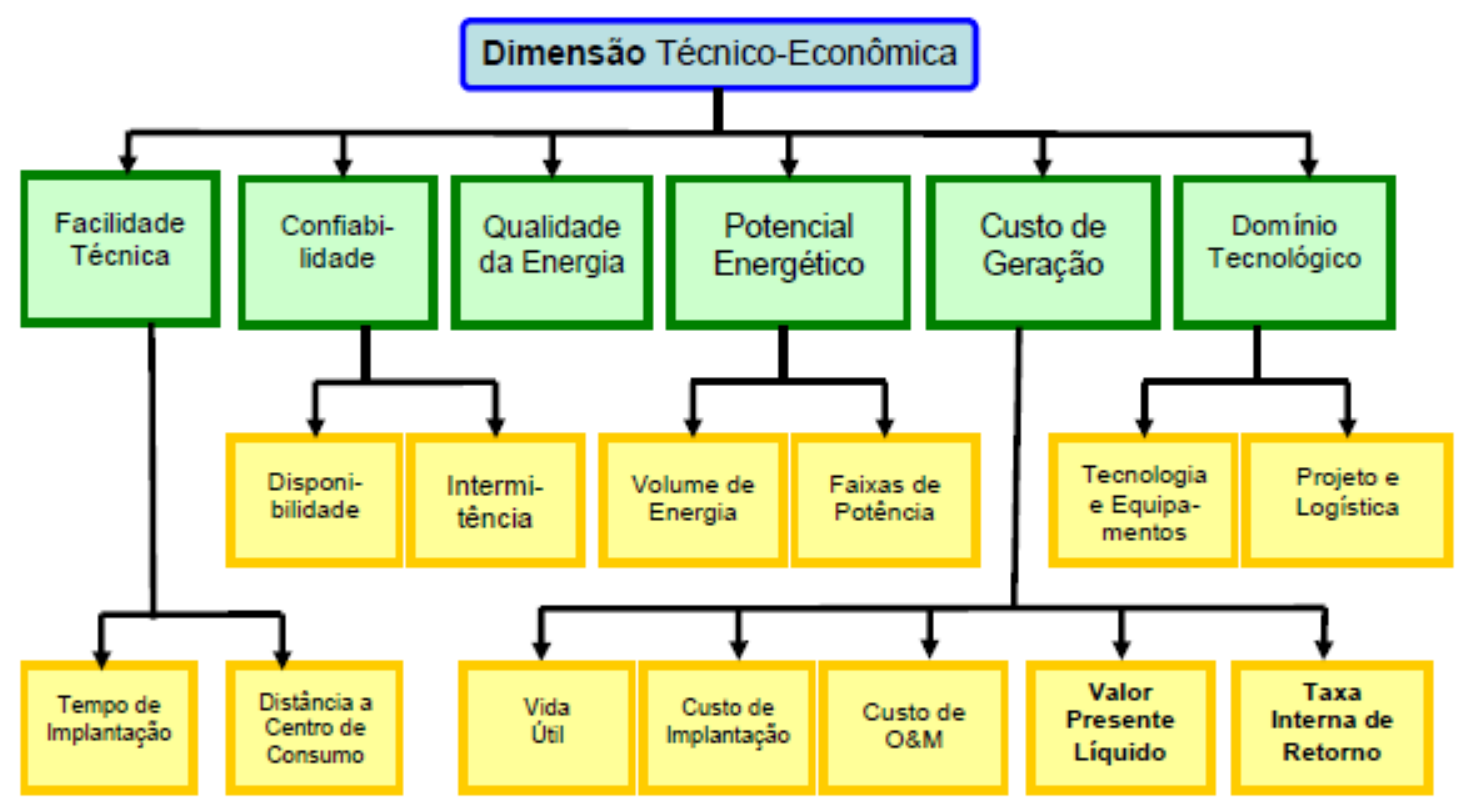

Figura 42 - Árvore de atributos e subatributos da dimensão técnico-econômica Fonte: [41]

\subsubsection{Custo de geração}

Para o custo de geração, serão analisados seus subatributos.

O Valor Presente Líquido (VPL) é uma técnica para mensurar a lucratividade de um projeto. Esse método poder ser aplicado em diferentes situações com base na previsão de fluxos de caixa futuros do investimento. A lucratividade é proporcional ao seu VPL.

A Taxa Interna de Retorno (TIR) é aquela que desconta os fluxos de caixa líquidos e iguala sua rentabilidade ao custo de oportunidade do capital, igualando o VPL desse investimento a zero.

Na tabela a seguir podemos verificar o TIR e o VPL de caldeiras de recuperação e de gaseficadores de licor negro. 
Tabela 15 - TIR e VPL de caldeira da recuperação e gaseificadores de licor negro

\begin{tabular}{|c|c|c|}
\hline & $\begin{array}{l}\operatorname{TIR}(*) \\
\text { (\%aa) }\end{array}$ & $\begin{array}{c}\text { VPL } \\
\text { (MMUS\$) }\end{array}$ \\
\hline Caldeira de Recuperação & 14,22 & 28 \\
\hline Gaseificador Baixa Temp. Turbina Médio porte & 11,61 & 21,9 \\
\hline Gaseificador Alta Temp. Turbina Médio porte & 16,14 & 72,8 \\
\hline Gaseificador Alta Temp. Turbina Grande porte & 17,53 & 111,1 \\
\hline
\end{tabular}

(*) As TIR são resultados da análise financeira dos autores para a situação dos EUA

Fonte:[1] e [7][2003] e [2006]

O custo de instalação (tabela 16), medido em função do kW instalado, inclui a contabilização das despesas de todo o ciclo de construção de um empreendimento.

Tabela 16 - Custo de instalação

\begin{tabular}{lc}
\hline \multicolumn{1}{c}{ Recurso } & $\mathrm{R} \$ / \mathrm{KW}$ \\
\hline Caldeira de Biomassa & 2400,00 \\
Caldeira de Recuperação & 3897,00 \\
Caldeira à Gás Natural/Óleo & 2100,00 \\
Hidroeletricidade & 2900,00 \\
Gaseificador de Licor Negro & 7734,00 \\
\hline
\end{tabular}

Fonte: Elaboração própria

Os custos operacionais (tabela 17) abrangem custos de operação e manutenção, administrativos, de combustível, seguros, entre outros. Eles também compreendem ações de caráter preventivo e corretivo ao longo da operação do empreendimento energético. Possuem uma componente fixa que depende da potência instalada e é dada por unidades monetárias $(\mathrm{R} \$) / \mathrm{kW}$ instalado.

Tabela 17 - Custo de O\&M

\begin{tabular}{lc}
\hline \multicolumn{1}{c}{ Recurso } & $\mathrm{R} \$ / \mathrm{KW}$ \\
\hline Caldeira de Biomassa & 25,00 \\
Caldeira de Recuperação & 26,00 \\
Caldeira à Gás Natural/Óleo & 40,00 \\
Hidroeletricidade & 55,00 \\
Gaseificador de Licor Negro & 42,00 \\
\hline
\end{tabular}

Fonte: Elaboração própria 
A vida útil de um projeto é o período em que conjunto, empreendimento e equipamentos funcionam em condições-padrão de rendimento de conversão e geração de energia. Sua estimativa fundamenta-se na probabilidade de degradação dos componentes e materiais utilizados.

A vida útil média de caldeira de biomassa, recuperação, gás natural/óleo, hidroeletricidade e gaseificador são respectivamente: 25, 20, 25, 30 e 20 anos.

\subsubsection{Domínio tecnológico}

Ele representa o índice de nacionalização de um empreendimento energético em função dos equipamentos e serviços envolvidos, podendo ser totalmente nacionais, mistos ou inteiramente importados. É uma informação particular de cada empreendimento e sua evolução não depende da disponibilidade de uma fonte energética, mas sim do estágio de desenvolvimento tecnológico e do aprendizado em pesquisas referentes às tecnologias utilizadas para cada fonte. Também está sujeito às restrições para a fabricação dos componentes tecnológicos.

No caso das caldeiras de biomassa, gás/óleo e recuperação, o Brasil possui empresas que utilizam tecnologia importada ou sob licença, que já atuam há vários anos e têm experiência em sua fabricação. Já os gaseificadores de licor negro ainda estão numa fase inicial. Existem poucas plantas que os operam em caráter experimental, todas no exterior. As usinas hidroelétricas são de domínio praticamente nacional. 


\subsubsection{Facilidade técnica}

Com relação ao atributo facilidade técnica, há:

O tempo de implantação, item fundamental, é variável de acordo com as condições de financiamento, a tecnologia empregada, a qualidade do projeto e a capacitação dos serviços contratados, dependendo do porte e da localização do empreendimento. Ela também é particular a cada empreendimento.

É a distância do recurso energético ao centro de consumo que determina o custo de transmissão e distribuição para o transporte da energia gerada ao consumidor final. O tempo de implantação de uma caldeira de biomassa é de aproximadamente oito meses; a caldeira de recuperação, 24 meses; caldeiras de gás natural/óleo, 36 meses; e gaseificadores de licor, 30 meses. Para todas as caldeiras, a distância é zero, pois elas se encontram instaladas dentro das fábricas.

\subsubsection{Confiabilidade}

A confiabilidade varia de acordo com a faixa de potência e é resultante de fatores como a intermitência de alguns recursos e a indisponibilidade de combustíveis ou equipamentos.

O fator de capacidade para a caldeira de biomassa é de 0,8 ; caldeiras de recuperação e gaseificadores de licor, 0,98; caldeiras de gás/óleo 0,9; e hidroeletricidade, 0,55 . 


\subsubsection{Potencial energético}

O volume de energia varia de acordo com a potência e o fator de capacidade de cada recurso, sua valoração é dividida por faixas de potências. O uso de faixas de potência facilita a análise de recursos. No caso das caldeiras de biomassa, gás/óleo e recuperação, ela se encontra na faixa de 2 a $30 \mathrm{MW}$, enquanto que a hidroeletricidade e o gaseificador, na faixa de 30 a $200 \mathrm{MW}$.

\subsection{Dimensão política}

Esta dimensão analisa um conjunto de fatores capazes de orientar e avaliar a inclusão de um determinado recurso energético. É dividida em atributos que quantificam, para cada recurso energético, os seguintes aspectos:

- a origem e a posse de fontes energéticas;

- a política de integração energética regional;

- o apoio político à implementação de um empreendimento ou da expansão estratégica de um recurso.

- a análise da interação entre os envolvidos e interessados nas problemáticas energéticas.

Foi reduzido o grau de subjetividade no processo de valoração por meio da proposição de indicadores híbridos, capazes de mensurar satisfatoriamente o potencial de conversão desses esforços políticos na implementação dos recursos energéticos. A valoração procurou quantificar a intensidade ou o volume de apoio em função de metas numéricas de implementação, previstas e/ou alcançadas ao longo do tempo. A posse e o potencial de utilização são medidos pelo grau de nacionalização de empreendimentos.

$\mathrm{Na}$ Figura abaixo, há a estrutura da árvore da dimensão política, com os 
respectivos atributos e subatributos utilizados como indicadores de valoração no PIR.

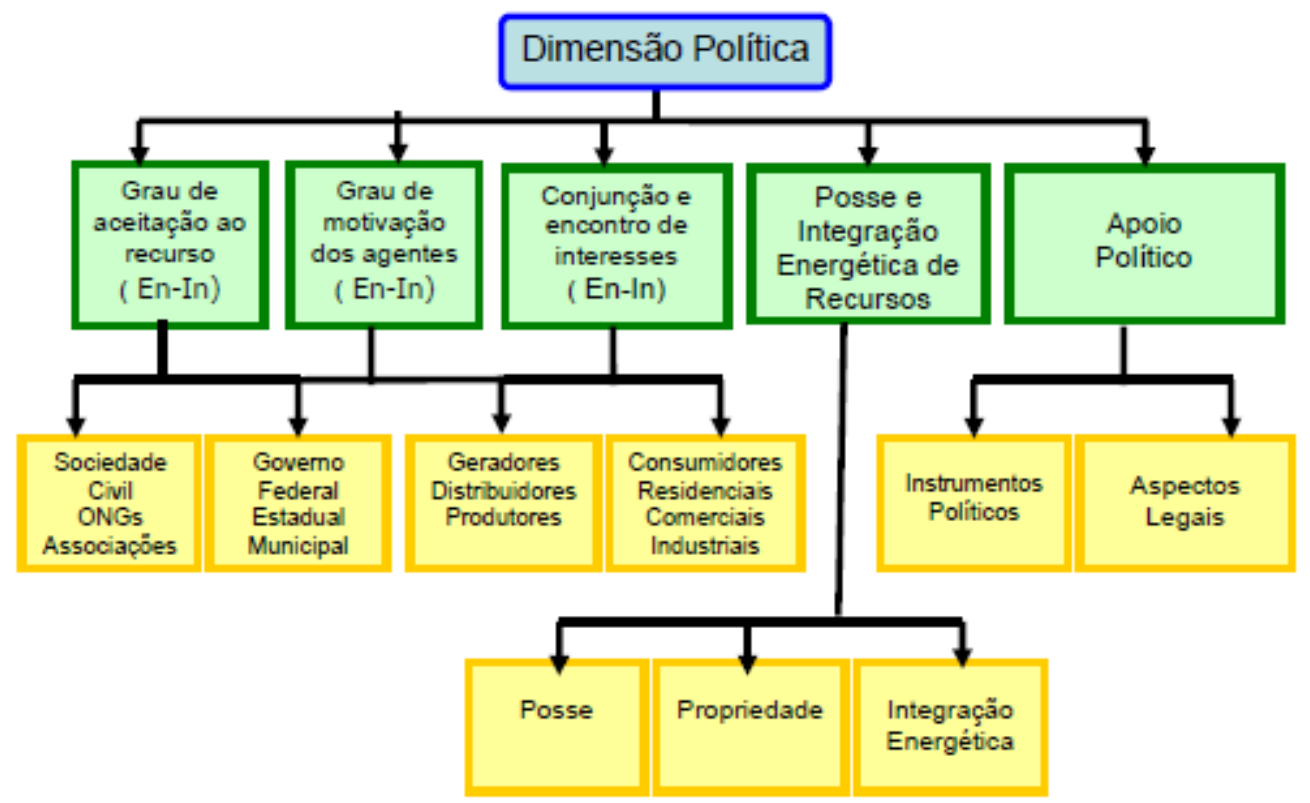

Figura 43 - Árvore de atributos e subatributos da dimensão política

Fonte: [41]

\subsubsection{Apoio político}

Na sequência estão os principais instrumentos políticos de incentivo para geração de energia. São incentivos como estes que podem levar as energias alternativas ao sucesso:

- Tarifas Feed-in: valor especial pago pelas concessionárias de energia por eletricidade oriunda de fontes renováveis.

- Sistemas de Cotas e Certificados Verdes: política que estabelece um mínimo de contratação da demanda das concessionárias em energias renováveis.

- Sistema de licitação e leilão: utilizado para fomentar investimentos em recursos energéticos e capaz de apoiar geradores.

- Subsídios e medidas fiscais: representados por taxas de retorno especiais acima de superar o alto custo inicial de investimento em empreendimentos menos econômicos. 
Dentre os programas de incentivo para os recursos de biomassa, existe o Programa de Incentivo às Fontes Alternativas de Energia Elétrica. No caso da gaseificação de licor negro, pode-se utilizar o programa do Banco Nacional de Desenvolvimento BNDS - PSI inovação [54].

\subsubsection{Posse de fonte energética e integração transfronteiriça}

Analisa a origem e a posse de fontes energéticas, considerando sua disponibilidade e o prolongamento da utilização. A análise da propriedade é fundamental para a viabilidade da exploração de uma fonte energética e sua implementação em determinado local.

O conceito de posse ou propriedade mostra diferentes possibilidades e características para acordos de exploração e utilização das fontes, cujo uso é classificado como livre ou público, de propriedade da união ou estatal ou ainda particulares ou privados. No caso analisado, os recursos são de posse privada.

A integração energética entre regiões e países é fundamental para permitir o acesso às fontes, que se mostram distribuídas não uniformemente ao redor do mundo, podendo ser por meio de transporte de combustíveis, pelo compartilhamento de usinas hidroelétricas ou indiretamente, através da construção de linhas de transmissão, permitindo o envio de energia das fontes geradoras até o mercado consumidor.

Neste trabalho, somente o recurso de hidroeletricidade se utiliza da integração energética, pois ela é produzida em Minas Gerais e é consumida em São Paulo. No caso dos outros recursos analisados, a energia é produzida localmente, dentro da fábrica. 


\subsubsection{Envolvidos e Interessados (En-In)}

En-In é uma terminologia utilizada pelo grupo de estudos do PIRnaUSP para caracterizar os diferentes atores ou stakeholders em diferentes graus de envolvimento em problemáticas energéticas locais ou regionais, unindo assim empreendedores e geradores de um dado recurso, populações impactadas (positiva ou negativamente por um dado empreendimento), associações que defendem interesses de ambas as partes. Todos são determinantes em maior ou menor escala para a implantação (ou não) de recursos energéticos.

De forma sintética, os principais En-In para os recursos energéticos do lado da oferta são:

- Governo, representado por diferentes ministérios e secretarias;

- Agências reguladoras de eletricidade e energéticos;

- Empresas do setor elétrico e coordenação de atividades (geração, transmissão e distribuição);

- Mídia (jornais, revistas, televisão etc.);

- Sociedade em geral (cidadãos).

Estes serão os agentes determinantes para a implantação de recursos energéticos, com estratégias e ações que se diferem para cada grupo e com eficácia diferenciada.

\subsection{Dimensão social}

O atributo dimensão social relaciona as consequências dos diferentes impactos sobre a sociedade. Ele analisa também a interferência de empreendimentos sobre habitantes, considerando tanto casos extremos, como o deslocamento de populações, quanto alterações da percepção de conforto, como poluição sonora, 
visual, entre outras. Além disso, analisam os impactos sobre o desenvolvimento de uma região, medindo parâmetros como geração de empregos locais, influências sobre a saúde ocupacional, entre outros.

A valoração desse atributo é um processo heterogêneo quanto à produção é cálculos de indicadores. A valoração de impactos ambientais ao meio social é medida por índices que quantificam a população afetada. A valoração de impactos sobre o desenvolvimento humano e saúde ocupacional pode ser estimada por indicadores econômicos e projeções desses parâmetros para cada recurso energético.

As maiores dificuldades recaem no atributo que analisa a alteração de percepção de conforto. O teor subjetivo desses elementos dificulta sua formatação em parâmetros numéricos ou técnicos. Na figura abaixo temos uma árvore com os atributos e subatributos deste dimensão.

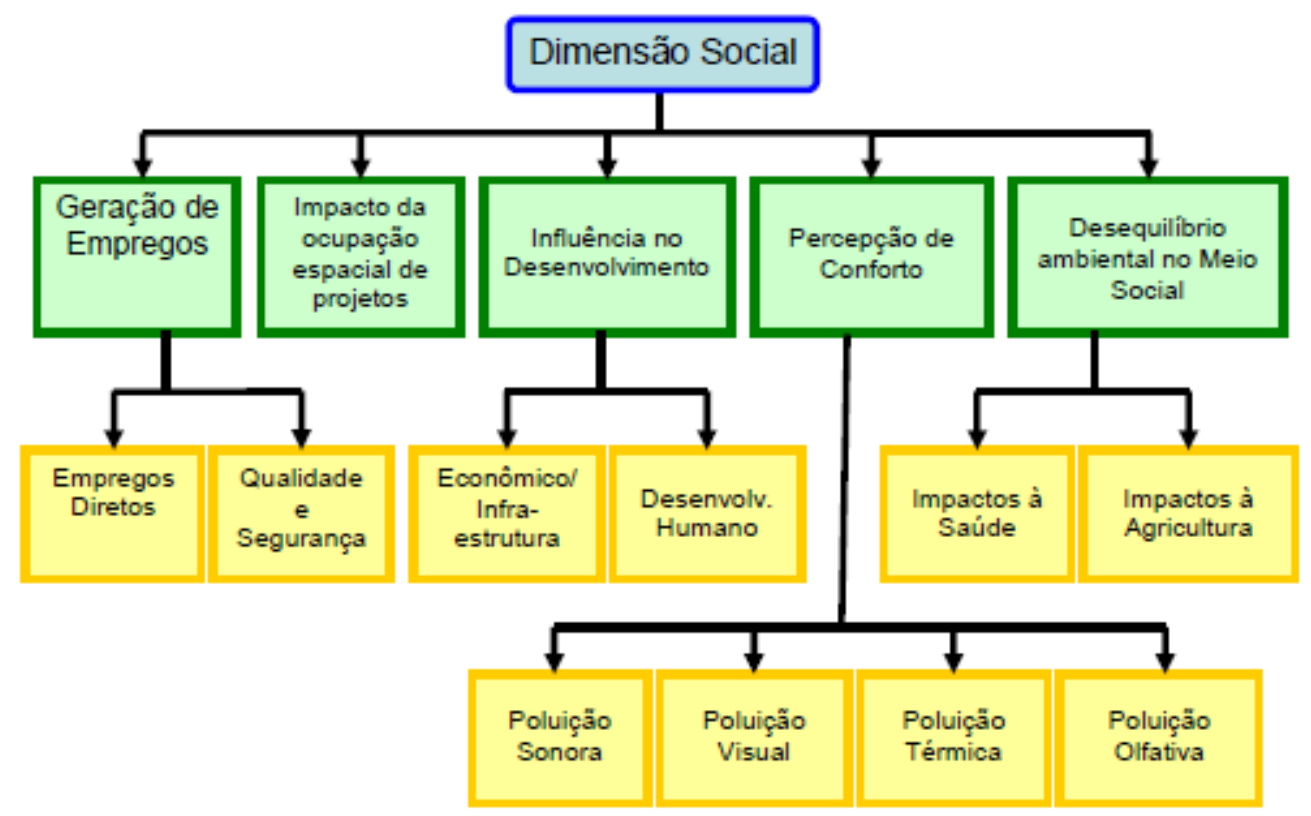

Figura 44 - Árvore de atributos e subatributos da dimensão social

Fonte: [41] 


\subsubsection{Quantidade de empregos}

É um subatributo que mede a geração de empregos decorrente de um empreendimento energético. Este é um impacto positivo, que interfere na qualidade de vida da população, representado pela reversão da geração de riqueza em ganhos de saúde, educação e infraestrutura. Ele também aumenta a renda, reduzindo a pobreza e trazendo os benefícios do crescimento econômico.

Sua valoração é iniciada pela discriminação dos potenciais postos de trabalho nas diferentes etapas da cadeia energética envolvida no recurso analisado, resultando em duas componentes: a multiplicação da capacidade instalada de cada recurso pela correção das taxas de emprego de cada etapa produtiva; e a geração de empregos indiretos, estimada pela produção de setores provedores da cadeia energética analisada.

Para este trabalho, devido à falta de informação detalhada, a valoração foi simplificada. Foram considerados basicamente os impactos de geração de empregos durante e após sua implementação.

Durante a fase de implementação, os impactos dos recursos de caldeira de biomassa, gás natural/óleo e gaseificador de licor são relativamente baixos e os de recuperação são maiores. $O$ recurso de hidroeletricidade é o que gera maior quantidade de empregos.

\subsubsection{Impactos de desequilíbrio ambiental no meio social}

A valoração deste atributo mensura danos à saúde humana resultantes da contaminação ambiental dos meios e suas implicações sobre o cultivo de alimentos, provisão de água e qualidade do ar. Ela se vale do uso de indicadores disponíveis na 
literatura, levantados por diferentes pesquisas nacionais e internacionais. Pode ser dividida em três meios principais: aéreo, terrestre e aquático.

Dentre os recursos selecionados, todos com exceção da hidroeletricidade, podem gerar impactos à saúde pública, pois eles geram poluentes atmosféricos, mesmo que mínimos. Os impactos devido ao uso da água são baixos, pois a fábrica possui uma estação de tratamento de efluentes, que os trata antes de devolver a água consumida.

\subsubsection{Impacto humano decorrente da ocupação espacial de projetos}

Ele avalia a interferência de empreendimentos sobre o espaço ocupado, com consequências sobre habitantes dos meios urbano e rural. Outro impacto é a pressão sobre a infraestrutura urbana, no caso, da migração temporária de trabalhadores. Há também os impactos relacionados a perdas estéticas culturais e históricas de territórios, desde a transformação de rios e montanhas até a ocupação e danificação de sítios arqueológicos.

No caso dos recursos selecionados, com exceção da hidroeletricidade, os impactos gerados são principalmente durante a construção, devido ao aumento de trabalhadores temporários; os outros impactos são menores.

No caso da hidroeletricidade, os impactos são maiores, pois, além do aumento de trabalhadores temporários, pode ocorrer migração de parte da população onde for implementado o recurso, devido ao alagamento para formação da lagoa e perda de áreas cultiváveis ou de agropecuária; também pode ocorrer a perda de sítios arqueológicos. 


\subsubsection{Influência no desenvolvimento local}

O desenvolvimento reflete na sociedade sob três perspectivas: econômica, estrutural e humana.

Pode-se medi-lo por diferentes fatores, como variação do produto interno bruto, receita oriunda de impostos, entre outros. Ela indica a perspectiva de aprimoramento da infraestrutura da região, se o aumento de PIB pode se reverter em melhorias de planejamento e condições de serviços públicos.

No caso dos recursos selecionados, como eles fazem parte de um todo que é uma fábrica de papel e celulose, é difícil verificar o impacto individualmente, com a exceção da hidreeletricidade, que gera royalties onde for instalada.

\subsubsection{Alteração de percepção de conforto}

Este atributo analisa fatores de impactos particulares a um indivíduo ou uma comunidade. Eles consideram diferentes tipos de poluição que retratam alterações de conforto associadas a recursos. Os tipos de poluição valoradas são visual, olfativa e térmica.

A valoração desses diferentes tipos de poluição segue uma metodologia de medição local. A quantificação de conforto é a diferença percentual entre valores calculados e valores máximos permitidos por legislação para cada caso ou local estudado.

No caso das indústrias de papel e celulose, uma das características marcantes é o odor gerado durante o processo, devido à presença de enxofre (S). Entre os recursos selecionados, os que podem gerar compostos com enxofre são a caldeira de recuperação e o gaseificador de licor negro, sendo que a segunda opção gera uma porcentagem menor. 


\subsection{Dimensão ambiental}

A dimensão ambiental relaciona os diferentes impactos gerados pelos empreendimentos energéticos sobre o meio ambiente. As alterações sobre o meio ambiente interferem diretamente sobre a qualidade de vida de toda sociedade. $\mathrm{O}$ meio ambiente é composto de um conjunto de fatores que afetam e determinam o comportamento e a sobrevivência dos seres vivos que o habitam, sendo assim, dividi-lo em atributos e organizar a análise das perturbações das atividades energéticas sobre estes meios têm total sentido (figura 45).

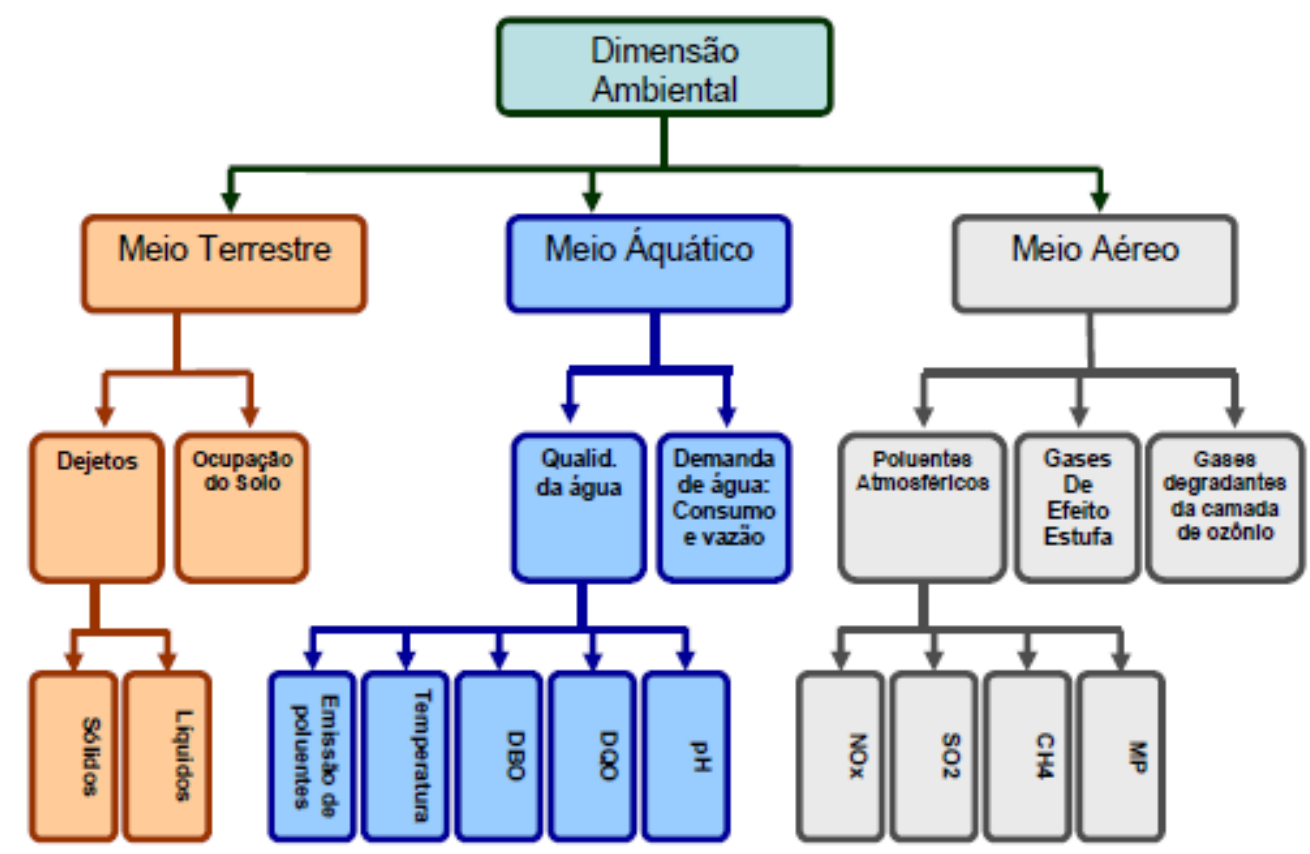

Figura 45 - Árvore de atributos e subatributos da dimensão ambiental Fonte: [6]

A alteração da qualidade dos parâmetros ambientais e a transformação desses recursos acontecem em diferentes etapas, desde a extração até seu uso final em diferentes setores.

A valoração de impactos ambientais é extremamente complexa. A seguir, comentários sobre os principais atributos. 
Os impactos no meio aéreo consideram a variação da concentração de diferentes substâncias poluentes na atmosfera. Os impactos ao meio terrestre incluem a deposição de poluentes aéreos no solo, a geração de resíduos sólidos tóxicos e o uso e a degradação do solo. No meio aquático, os impactos podem ser divididos em dois grupos principais: a demanda de recursos hídricos e a geração de efluentes líquidos.

A demanda de recursos hídricos é avaliada em função de sua captação e seu consumo para fins energéticos. A geração de efluentes líquidos considera condicionantes de emissão em corpos d'água e alteração de parâmetros de qualidade das águas.

\subsubsection{Poluição atmosférica}

Mudanças climáticas decorrentes da poluição atmosférica pela emissão de gases de efeito estufa são umas das principais ameaças à vida. Este atributo trata do acréscimo de emissões de poluentes à atmosfera resultante das atividades da cadeia energética, na forma de diferentes substâncias químicas, material particulado e outras. Os impactos ambientais resultantes dessas substâncias podem ser globais, como efeito estufa, ou locais, como chuva ácida e smog.

O atributo poluição atmosférica computa as emissões de todas as etapas da cadeia energética. O uso energético nessas etapas provoca emissões por fontes móveis e estacionárias. A essas emissões soma-se a produção de poluentes secundários formados por transformações químicas de poluentes diretos na atmosfera. Na tabela 18 podemos verificar as emissões típicas de uma caldeira de recuperação. 
Tabela 18 - Emissões atmosféricas típicas de caldeiras de recuperação

\begin{tabular}{|c|c|c|c|c|c|}
\hline & Unidade & $\begin{array}{l}\mathrm{SO}_{2} \\
(\mathrm{~S})\end{array}$ & $\begin{array}{c}\text { Material } \\
\text { particulado }\end{array}$ & $\mathrm{NOx}(\mathrm{NO} 2)$ & $\begin{array}{l}\text { TRS } \\
(\mathrm{S})\end{array}$ \\
\hline \multicolumn{6}{|l|}{$\begin{array}{ll}\text { Caldeira } & \text { de } \\
\text { recuperação } & \end{array}$} \\
\hline Sem lavador de gases & $\mathrm{mg} / \mathrm{Nm}^{3}$ & 100 a 800 & 10 a 200 & 100 a 260 & $<10$ \\
\hline-63 a $65 \%$ sólidos no & $\mathrm{mg} / \mathrm{MJ}$ & 60 a 250 & & 50 a 80 & \\
\hline licor negro & $\mathrm{kg} / \mathrm{ADT}$ & 1 a 4 & 0,1 a 1,8 & 0,6 a 1,8 & $<0,05$ \\
\hline Com lavador de gases & $\mathrm{mg} / \mathrm{Nm}^{3}$ & 20 a 80 & 10 a 200 & 100 a 260 & $<10$ \\
\hline - 63 a $65 \%$ sólidos no & $\mathrm{mg} / \mathrm{MJ}$ & 10 a 25 & & 50 a 80 & \\
\hline licor negro & $\mathrm{kg} / \mathrm{ADT}$ & 0,1 a 0,4 & 0,1 a 1,8 & 0,6 a 1,8 & $<0,05$ \\
\hline Sem lavador de gases & $\mathrm{mg} / \mathrm{Nm}^{3}$ & 10 a 100 & 10 a 200 & 100 a 260 & $<10$ \\
\hline - 72 a $80 \%$ sólidos no & $\mathrm{mg} / \mathrm{MJ}$ & 12 a 30 & & 50 a 80 & \\
\hline licor negro & $\mathrm{kg} / \mathrm{ADT}$ & 0,2 a 0,5 & 0,1 a 1,8 & 0,6 a 1,8 & $<0,05$ \\
\hline
\end{tabular}

Fonte: [52][2003]

No caso das caldeiras de biomassa, há a emissão entre 70 e 100 mgNOx/MJ e de material particulado(MP), entre 20 e $40 \mathrm{mgMP} / \mathrm{Nm}^{3}$.

\subsubsection{Gases de efeito estufa}

Neste atributo quantifica-se a emissão de gases de efeito estufa. Ainda que a emissão seja quantificada no atributo de poluição atmosférica, a contabilização se justifica pelo nível de criticidade e urgência com a qual esse assunto é tratado atualmente em fóruns nacionais e internacionais.

$\mathrm{O}$ aumento das emissões de $\mathrm{CO}_{2}$ tem sido provocado pelo uso cada vez mais intenso de combustíveis fósseis no setor de transportes, no aquecimento e na refrigeração. As emissões de $\mathrm{NO}_{2}$ também são resultantes do uso de combustíveis fósseis. As emissões de metano derivam de fugas durante extração, transporte e 
distribuição de petróleo e gás natural, além dos processamentos desses recursos energéticos. Na tabela 19 temos um comparativo entre as emissões das caldeiras de recuperação tradicionais e gaseificadores de licor negro.

Tabela 19 - Emissões de poluentes, caldeiras de recuperação e gaseificadores

\begin{tabular}{|c|c|c|c|c|}
\hline \multicolumn{5}{|c|}{ Emissões Totais (lb/MWh) } \\
\hline Poluentes & Tomlinson & $\begin{array}{l}\text { Baixa Temp. } \\
\text { Turbina Médio } \\
\text { Porte }\end{array}$ & $\begin{array}{c}\text { Alta Temp. } \\
\text { Turbina } \\
\text { Médio } \\
\text { Porte }\end{array}$ & $\begin{array}{c}\text { Alta Temp. } \\
\text { Turbina } \\
\text { Grande } \\
\text { Porte } \\
\end{array}$ \\
\hline $\mathrm{CO} 2$ & 5879 & 3278 & 3258 & 1985 \\
\hline SO2 & 0,81 & 0,25 & 0,27 & 0,11 \\
\hline NOx & 4,92 & 1,00 & 1,80 & 1,14 \\
\hline $\mathrm{CO}$ & 4,51 & 94,00 & 2,16 & 0,90 \\
\hline VOC & 0,37 & 2,19 & 0,07 & 0,03 \\
\hline $\mathrm{MP}$ & 1,34 & 0,07 & 0,24 & 0,12 \\
\hline TRS (S reduzido) & 0,09 & 0,26 & 0,01 & 0,00 \\
\hline
\end{tabular}

Fonte: [7][2006]

\subsubsection{Ocupação do solo}

A ocupação do solo constitui um dos principais impactos ao meio ambiente recorrente de empreendimentos energéticos. A avaliação é medida pela relação entre a capacidade instalada, ou a energia produzida pelo sistema, e a área ocupada, considerando as diferentes etapas da cadeia energética.

A valoração considera a razão entre a capacidade instalada do empreendimento e a área ocupada pela cadeia energética local do recurso. A razão entre a capacidade gerada e a área ocupada em um sistema energético é particular para cada recurso energético.

No caso das caldeira de gás e óleo, foram consideradas duas caldeiras com área ocupada de $100 \mathrm{~m}^{2}$ cada, a caldeira de biomassa ocupando $500 \mathrm{~m}^{2}$ e as duas caldeiras de recuperação ocupando $500 \mathrm{~m}^{2}$ cada (informação pessoal). As usinas 
hidroelétricas de Amador Aguiar I e II ocupam em conjunto 64 km².

\subsubsection{Poluição e degradação do solo}

Fazem parte do atributo meio terrestre e incluem a deposição de poluentes ou dejetos no solo e em vegetais. Eles provocam desequilíbrios em ecossistemas naturais e urbano. Esse efeito é propagado quando a transferência de poluentes por cursos d'água ou lençóis freáticos amplia a área contaminada, ameaçando a fauna, a flora e as comunidades próximas e podendo tornar o solo impróprio temporariamente ou permanentemente em casos extremos.

A medição de impactos de poluentes é função do peso ou volume líquido dos dejetos ou resíduos produzidos em proporção à energia gerada por eles. A valoração se faz de acordo com a massa desse resíduo em função da energia ou eletricidade produzida no processo.

As caldeiras de gás e óleo praticamente não causam impacto no solo. As caldeiras de biomassa geram cinzas que podem ser reaproveitadas como adubo. As caldeiras de recuperação em si também não causam impacto ao solo, as cinzas geradas são reaproveitadas dentro do processo. As duas usinas hidroelétricas não geram resíduos sólidos.

\subsubsection{Consumo de recursos hídricos}

Faz parte do atributo de meio aquático. Nos empreendimentos energéticos, tem participação em todas as etapas de sua cadeia energética. A avaliação é organizada em função de seu uso e sua qualidade do recurso devolvido aos corpos d'água e mananciais. 
Este atributo avalia a demanda de recursos hídricos em relação a sua captação e seu consumo para fins energéticos.

As duas caldeiras de recuperação consomem em média 25,6 t/MWh; a caldeira de biomassa, 12,6 t/MWh; as caldeiras a gás/óleo, 25,3 t/MWh [50]; e o gaseificador de licor negro, 0,6 t/MWh [7]. As usinas hidroelétricas não consomem água,pois a água utilizada para gerar energia é devolvida ao curso do rio.

\subsubsection{Qualidade da água}

A análise da qualidade da água devolvida aos corpos d'água, mananciais ou rios é um fator de grande importância. Ela implica na manutenção de suas condições originais de temperatura, acidez e outras variáveis; sua alteração pode implicar diferentes desequilíbrios ecológicos e impactos à sociedade.

A valoração deste atributo baseia-se na medição de alteração dos parâmetros de acidez $(\mathrm{pH})$, temperatura (graus Celsius), demanda de oxigênio (DBO e DQO) e concentração de poluentes químicos (gramas por litro).

O algoritmo pondera as características do efluente líquido em função do volume total de efluente produzido na aplicação do potencial de geração do recurso analisado.

No caso das caldeiras, todo efluente vai para uma estação de tratamento dentro da fábrica e é devolvido ao rio dentro dos limites legalmente estabelecidos. No caso das usinas hidroelétricas, a variação de qualidade da água é pequena.

As emissões de efluentes das caldeiras de recuperação giram em torno de 1 a 2 $\mathrm{m}^{3} / \mathrm{tsa}$. Os valores típicos de DBO5 são de 0,5 a 1,0 kg/tsa [53].

Os efluentes gerados pelas caldeiras têm características de $\mathrm{pH}$ alcalino. 


\section{Ranqueamento}

Para realizar esta etapa, utiliza-se a Análise dos Custos Completos (ACC), que prioriza elementos de acordo com um ranqueamento numérico provindo da caracterização realizado no capítulo anterior. Para auxiliar no tratamento de dados, utilizou-se a ferramenta chamada Processo de Análise Hierárquica - PAH (ou Analytic Hierarchy Process - AHP), que é um método de tomada de decisão que auxilia na determinação de prioridades e também identifica a melhor opção dentro de várias alternativas possíveis, levando em conta tanto aspectos quantitativos quanto qualitativos. O PAH se originou de trabalhos do professor Thomas L. Saaty, na década de 1970, para analisar o conflito militar no Oriente Médio. Entretanto, esses trabalhos iniciais não consideravam aspectos importantes por não ser quantificável. Mais tarde, baseando-se em conceitos de Álgebra Linear, pesquisa operacional e psicologia, o professor Saaty desenvolveu o PAH.

No PIRnaUSP se utilizou de uma técnica de auxílio de tomada de decisão através da criação de rankings das alternativas, numa comparação par a par entre os critérios, seguida da comparação entre os subcritérios, dentro de cada um dos critérios, gerando assim dois ranqueamentos: o Determinístico (provindo de dados da valoração) e o Holístico (provindo de dados dos especialistas e En-In).

O Ranqueamento total considera a médias entre os dois ranqueamentos. $\mathrm{O}$ resultado final é demonstrado na forma ordenada, do mais indicado para o menos indicado. [61]

A seguir, é possível ver o resultado do ranqueamento determinístico oriundo da utilização de escalas (ratings): 
Tabela 20 - Resultado ranqueamento determinístico

\begin{tabular}{lc}
\hline \multicolumn{1}{c}{ Recurso } & Média \\
\hline Hidroeletricidade & 0,67 \\
Caldeira de Biomassa & 0,59 \\
Caldeira à Gás Natural/Óleo & 0,56 \\
Caldeira de Recuperação & 0,37 \\
Gaseificador de Licor Negro & 0,31 \\
\hline
\end{tabular}

Abaixo, o resultado do ranqueamento holístico:

Tabela 21 - Resultado ranqueamento

\begin{tabular}{lc}
\hline \multicolumn{1}{c}{ Recurso } & Média \\
\hline Hidroeletricidade & 0,68 \\
Caldeira à Gás Natural/Óleo & 0,52 \\
Caldeira de Recuperação & 0,50 \\
Caldeira de Biomassa & 0,48 \\
Gaseificador de Licor Negro & 0,30 \\
\hline
\end{tabular}

Fazendo-se a média entre os dois ranqueamentos, há o ranqueamento final abaixo:

Tabela 22 - Ranqueamento final

\begin{tabular}{lc}
\hline \multicolumn{1}{c}{ Recurso } & Ranking \\
\hline Hidroeletricidade & $1^{\circ}$ \\
Caldeira de Biomassa & $2^{\circ}$ \\
Caldeira à Gás Natural/Óleo & $3^{\circ}$ \\
Caldeira de Recuperação & $4^{\circ}$ \\
Gaseificador de Licor Negro & $5^{\circ}$ \\
\hline
\end{tabular}

O resultado mostra que o recurso, hidroeletricidade, é a melhor opção energética, seguido dos outros recursos, estes resultados ajudam o tomador de decisão, qual recurso deve atuar primeiro em relação ao outros recursos.

As planilhas determinísticas e holísticas do RELOs podem ser visualizadas nos apêndices A e B. 


\section{Mapeamento regional}

Este mapeamento contém os indicadores ambientais que podem influenciar o tomador de decisões em novas alternativas e projetos com relação às questões energéticas. Deste modo, o mapeamento poderá explicitar a situação atual e compará-la com os parâmetros identificados na legislação e normas referentes, determinando alternativas que poderão ser planejadas sem extrapolar esses limites.

Ela produz o retrato instantâneo dos parâmetros medidos, inferidos ou analisados. A importância desse retrato reside em considerar esses limites e concentrações quando da inclusão do recurso ranqueado para atender a demanda prevista em determinado cenário. Caso ele não atenda os limites estabelecidos, este recurso poderá ser desconsiderado.

Com o objetivo de simplificar a assimilação pelos usuários. Para facilitar e ordenar a apresentação dos indicadores, eles foram divididos em quatro diferente meios:

- Meio antropogênico

- Meio aéreo

- Meio aquático

- Meio terrestre

\subsection{Caracterização do meio antrópico}

Indicadores demográficos como crescimento populacional, concentração, entre outros possibilitam o estudo sobre a sociedade brasileira. Esses dados são fontes de referência sobre a situação da vida da população nos municípios.

Dados relacionados sobre a saúde e a educação também permitem verificar o 
estado de desenvolvimento social. Dados de empregos e rendimentos, assim como aspectos gerais da economia, foram relacionados nas tabelas seguintes.

Tabela 23 - Dados primários relativos ao meio antropogênico - Território e População

\begin{tabular}{|c|c|c|c|c|c|c|c|c|c|}
\hline & (2011*) & (2011*) & (2011*) & (2011*) & (2011*) & (2011*) & (2011*) & $(2011 *)$ & (2000-2010*) \\
\hline localidade & população & área & densidade & $\begin{array}{c}\text { grau de } \\
\text { urbanização }\end{array}$ & $\begin{array}{c}\text { Indice de } \\
\text { envelhecimento }\end{array}$ & $\begin{array}{l}\text { População } \\
\text { com } 60 \text { anos } \\
\text { ou mais }\end{array}$ & $\begin{array}{l}\text { População } \\
\text { com menos } \\
\text { de } 15 \text { anos }\end{array}$ & $\begin{array}{c}\text { Razão de } \\
\text { sexos }\end{array}$ & $\begin{array}{c}\text { Taxa geométrica de } \\
\text { crescimento anual da } \\
\text { população }\end{array}$ \\
\hline & hab & $\mathrm{km} 2$ & hab/km2 & (em \%) & (em \%) & (em \%) & (em \%) & (em \%) & (em \% а.а.) \\
\hline Suzano & 256.687 & 205,85 & $1.290,56$ & $96,48 \%$ & 34,96 & 8,7 & 24,9 & 96,21 & 1,4 \\
\hline
\end{tabular}

Fonte: [13]

Tabela 24 - Dados primários relativos ao meio antropogênico - Condições de vida

\begin{tabular}{|c|c|c|c|c|c|c|c|c|c|c|c|c|}
\hline \multirow[b]{3}{*}{ localidade } & \multirow{3}{*}{$\begin{array}{l}\left(2000^{*}\right) \\
\text { IDHM }\end{array}$} & \multirow{3}{*}{$\begin{array}{l}\left(2000^{*}\right) \\
\text { Ranking }\end{array}$} & \multirow{2}{*}{\multicolumn{4}{|c|}{$\begin{array}{c}\left(2008^{*}\right) \\
\text { IPRS }\end{array}$}} & \multicolumn{6}{|c|}{$\left(2000^{*}\right)$} \\
\hline & & & & & & & & & IPV & & & \\
\hline & & & IPR8 & \multicolumn{2}{|l|}{ Longevidade } & Escolaridade & $\begin{array}{l}\text { Grupo } 1 \\
(\mathrm{em} \%)\end{array}$ & $\begin{array}{r}\text { Grupo } 2 \\
(\mathrm{em} \%) \\
\end{array}$ & $\begin{array}{c}\text { Grupo } 3 \\
\text { (em\% a.a.) }\end{array}$ & $\begin{array}{l}\text { Grupo } 4 \\
(\mathrm{em} \%) \\
\end{array}$ & $\begin{array}{l}\text { Grupo } 6 \\
(\mathrm{em} \%)\end{array}$ & $\begin{array}{c}\text { Grupo } 8 \\
\text { (em \% a.a.) }\end{array}$ \\
\hline Suzano & 1 & 355 & Grupo 2 & 68 & 51 & 68 & 0,83 & 10,27 & 22,71 & 33,73 & 13,71 & 18,75 \\
\hline
\end{tabular}

Fonte: [13]

Tabela 25 - Dados primários relativos ao meio antropogênico - Economia

\begin{tabular}{cccccccccc}
\hline localidade agropecuária industrial & serviços & $\begin{array}{c}\text { administração } \\
\text { publica }\end{array}$ & PIB & $\begin{array}{c}\text { PIB per } \\
\text { capita }\end{array}$ & $\begin{array}{c}\text { \% no PIB do } \\
\text { Estado }\end{array}$ & $\begin{array}{c}\text { Participação nas } \\
\text { exportações do } \\
\text { Estado }\end{array}$ \\
& $(\mathrm{em} \%)$ & $(\mathrm{em} \%)$ & $(\mathrm{em} \%)$ & $(\mathrm{em} \%)$ & $\begin{array}{c}\text { (em milhões de } \\
\text { reais correntes) }\end{array}$ & $\begin{array}{c}\text { (em reais } \\
\text { correntes) }\end{array}$ & $(\mathrm{em} \%)$ & $(\mathrm{em} \%)$ \\
\hline Suzano & 0,3 & 54,1 & 45,6 & 10,9 & $5.559,88$ & $19.551,52$ & 0,51 & 0,965407 \\
\hline$\left(2009^{*}\right)$ & & & & & & & & &
\end{tabular}

Fonte: [13]

Tabela 26 - Dados primários relativos ao meio antropogênico - Educação

\begin{tabular}{|c|c|c|c|c|c|}
\hline & $(2000 *)$ & $\left(2000^{*}\right)$ & $\left(2000^{*}\right)$ & $\left(2000^{*}\right)$ & (2009*) \\
\hline localidade & $\begin{array}{c}\text { Média de anos } \\
\text { de estudos da } \\
\text { população de } 15 \\
\text { a } 64 \text { anos }\end{array}$ & $\begin{array}{l}\text { População de } \\
18 \text { a } 24 \text { anos } \\
\text { com ensino } \\
\text { médio } \\
\text { completo } \\
\text { (em \%) }\end{array}$ & $\begin{array}{l}\text { População de } \\
25 \text { anos e mais } \\
\text { com menos de } \\
8 \text { anos de } \\
\text { estudo } \\
\text { (em \%) }\end{array}$ & $\begin{array}{l}\text { Analfabetis } \\
\text { mo da } \\
\text { população } \\
\text { de } 15 \text { anos } \\
\text { e mais } \\
\text { (em \%) }\end{array}$ & $\begin{array}{l}\text { Despesas } \\
\text { Municipais } \\
\text { (em reais } \\
\text { correntes) }\end{array}$ \\
\hline Suzano & 7,1 & 40,59 & 61,51 & 7,83 & $101.063 .396,00$ \\
\hline
\end{tabular}

Fonte: [13] 
Tabela 27 - Dados primários relativos ao meio antropogênico - Habitação e Infraestrutura

\begin{tabular}{|c|c|c|c|c|c|c|c|c|}
\hline \multirow[b]{3}{*}{ Localidade } & \multicolumn{4}{|c|}{ Habitação } & \multicolumn{4}{|c|}{ Saneamento } \\
\hline & $(2000 *)$ & $\left(2003^{*}\right)$ & (2003*) & $(2000 *)$ & $(2000 *)$ & $\left(2003^{*}\right)$ & (2003*) & $\left(2003^{*}\right)$ \\
\hline & $\begin{array}{l}\text { Domicílios } \\
\text { com espaço } \\
\text { suficiente }\end{array}$ & $\begin{array}{l}\text { Existência } \\
\text { de áreas de } \\
\text { riscos com } \\
\text { moradias }\end{array}$ & $\begin{array}{l}\text { Número de } \\
\text { áreas de risco } \\
\text { ocupadas por } \\
\text { moradias }\end{array}$ & $\begin{array}{c}\text { Domicílios } \\
\text { com infra- } \\
\text { estrutura } \\
\text { interna urbana } \\
\text { adequada } \\
\text { (em \%) }\end{array}$ & $\begin{array}{l}\text { Abastecimen } \\
\text { to de água - } \\
\text { nível de } \\
\text { atendimento }\end{array}$ & $\begin{array}{c}\text { Domicílios } \\
\text { urbanos } \\
\text { abastecidos } \\
\text { com rede } \\
\text { pública de } \\
\text { distribuição de } \\
\text { água } \\
\text { (em \%) }\end{array}$ & $\begin{array}{l}\text { Economias } \\
\text { residenciais } \\
\text { ligadas ao } \\
\text { sistema de } \\
\text { abastecimento } \\
\text { de água }\end{array}$ & $\begin{array}{c}\text { Orgão ou } \\
\text { empresa } \\
\text { operadora do } \\
\text { sitema de } \\
\text { abastecimento } \\
\text { de água }\end{array}$ \\
\hline Suzano & 71,1 & Sim & 19 & 74,54 & 87,62 & 84,00 & 55,94 & Sabesp \\
\hline
\end{tabular}

Fonte: [13]

Tabela 28 - Dados primários relativos ao meio antropogênico - Empregos e Rendimentos

\begin{tabular}{|c|c|c|c|c|c|c|c|c|c|c|c|}
\hline \multirow{3}{*}{ localidade } & \multicolumn{5}{|c|}{ Participação dos vínculos empregatícios (2005*) } & \multicolumn{6}{|c|}{ Rendimento médio (2010*) } \\
\hline & $\begin{array}{c}\text { Agropecuaria } \\
\text { no total de } \\
\text { vinculos }\end{array}$ & $\begin{array}{l}\text { Construção } \\
\text { civil no total } \\
\text { de vínculos }\end{array}$ & $\begin{array}{l}\text { Indústria no } \\
\text { total de } \\
\text { vinculos }\end{array}$ & $\begin{array}{c}\text { Comércio no } \\
\text { total de } \\
\text { vinculos }\end{array}$ & $\begin{array}{l}\text { Serviços no } \\
\text { total de } \\
\text { vínculos }\end{array}$ & $\begin{array}{c}\text { Total de } \\
\text { Vínculos } \\
\text { empregatícios }\end{array}$ & $\begin{array}{c}\text { Vínculos } \\
\text { empregatícios } \\
\text { na } \\
\text { agropecuária }\end{array}$ & $\begin{array}{c}\text { Vinculos } \\
\text { Empregaticios } \\
\text { na Construção } \\
\text { Civil }\end{array}$ & $\begin{array}{l}\text { Vinculos } \\
\text { Empregatícios } \\
\text { na Indústria }\end{array}$ & $\begin{array}{c}\text { Vinculos } \\
\text { Empregatícios } \\
\text { no comércio }\end{array}$ & $\begin{array}{c}\text { Vínculos } \\
\text { Empregatícios } \\
\text { nos Serviços }\end{array}$ \\
\hline & (em \%) & (em \%) & (em \%) & $(\mathrm{em} \%)$ & (em \%) & $\begin{array}{l}\text { (Em reais } \\
\text { correntes) }\end{array}$ & $\begin{array}{l}\text { (Em reais } \\
\text { correntes) }\end{array}$ & $\begin{array}{l}\text { (Em reais } \\
\text { correntes) }\end{array}$ & $\begin{array}{l}\text { (Em reais } \\
\text { correntes) }\end{array}$ & $\begin{array}{c}\text { (Em reais } \\
\text { correntes) }\end{array}$ & $\begin{array}{l}\text { (Em reais } \\
\text { correntes) }\end{array}$ \\
\hline Suzano & 1,79 & 2 & 47,61 & 19,98 & 28,62 & $1.819,01$ & 733,3 & $1.119,12$ & $2.550,59$ & $1.052,14$ & $1.617,44$ \\
\hline
\end{tabular}

Fonte: [13]

Tabela 29 - Dados primários relativos ao meio antropogênico - Saúde

\begin{tabular}{|c|c|c|c|c|c|c|c|c|c|}
\hline \multirow{3}{*}{ localidade } & $\begin{array}{l}\text { Finanças Publicas } \\
\text { Municipais (2007*) }\end{array}$ & \multicolumn{4}{|c|}{ População e estatísticas vitais(2010*) } & \multicolumn{4}{|c|}{ Saúde $\left(2007^{*}\right)$} \\
\hline & $\begin{array}{l}\text { Total de despesas } \\
\text { municipais-saúde }\end{array}$ & $\begin{array}{c}\text { Taxa de } \\
\text { Fecundidade } \\
\text { geral }\end{array}$ & $\begin{array}{c}\text { Taxa de } \\
\text { mortalidade } \\
\text { infantil }\end{array}$ & $\begin{array}{c}\text { Taxa de } \\
\text { natalidade }\end{array}$ & $\begin{array}{c}\text { Taxa de } \\
\text { Natimortalidade }\end{array}$ & Leitos SUS & $\begin{array}{c}\text { Mães } \\
\text { adolescentes }\end{array}$ & $\begin{array}{l}\text { Nascimentos } \\
\text { de baixo } \\
\text { peso,com } \\
\text { menos de } \\
2,5 \mathrm{~kg}\end{array}$ & $\begin{array}{l}\text { Unidades de } \\
\text { atenção } \\
\text { básica de } \\
\text { saúde }\end{array}$ \\
\hline & (em reais) & $\begin{array}{c}\text { (por mil } \\
\text { mulheres entre } \\
15 \text { e } 49 \text { anos) }\end{array}$ & $\begin{array}{l}\text { (por mil } \\
\text { nascidos } \\
\text { vivos) }\end{array}$ & $\begin{array}{c}\text { (por mil } \\
\text { habitantes) }\end{array}$ & $\begin{array}{l}\text { (por mil nascidos } \\
\text { vivos ou mortos) }\end{array}$ & $\begin{array}{c}\text { (Coeficiente } \\
\text { por mil } \\
\text { habitantes) }\end{array}$ & $\begin{array}{c}\text { (com menos } \\
\text { de } 18 \\
\text { anos) }(\mathrm{em} \%)\end{array}$ & (em \%) & unidade \\
\hline Suzano & 70.066 .422 & 55,53 & 11,2 & 16,03 & 11,50 & 0,83 & 7,66 & 8,14 & 16 \\
\hline
\end{tabular}

Fonte: [13]

Tabela 30 - Dados primários relativos ao meio antropogênico - Meio Ambiente e Política Urbana

\begin{tabular}{|c|c|c|c|c|c|c|c|c|c|c|c|c|c|c|}
\hline \multirow[b]{2}{*}{ localidade } & \multicolumn{2}{|c|}{ Meio Ambiente (2003*) } & \multicolumn{12}{|c|}{ Política urbana (2003*) } \\
\hline & $\begin{array}{c}\text { Existência de } \\
\text { unidades de } \\
\text { conservação } \\
\text { ambiental } \\
\text { municipais }\end{array}$ & $\begin{array}{c}\text { Total de } \\
\text { unidades de } \\
\text { conservação } \\
\text { ambiental } \\
\text { municipais }\end{array}$ & $\begin{array}{l}\text { Existência de } \\
\text { conselho } \\
\text { municipal de } \\
\text { desenvolvime } \\
\text { nto urbano }\end{array}$ & $\begin{array}{l}\text { Existência de } \\
\text { lei de } \\
\text { parcelamento } \\
\text { do solo }\end{array}$ & $\begin{array}{c}\text { Existência } \\
\text { de lei de } \\
\text { perímetro } \\
\text { urbano }\end{array}$ & $\begin{array}{c}\text { Existência } \\
\text { de lei de } \\
\text { plano } \\
\text { diretor }\end{array}$ & $\begin{array}{l}\text { Existencia de } \\
\text { lei de } \\
\text { zoneamento }\end{array}$ & $\begin{array}{l}\text { Existência de } \\
\text { lei de } \\
\text { zoneamento } \\
\text { especial de } \\
\text { interesse } \\
\text { ambiental }\end{array}$ & $\begin{array}{l}\text { Existência de } \\
\text { lei de } \\
\text { zoneamento } \\
\text { especial de } \\
\text { interesse } \\
\text { cultural }\end{array}$ & $\begin{array}{l}\text { Existência de } \\
\text { lei de } \\
\text { zoneamento } \\
\text { especial de } \\
\text { interesse } \\
\text { social }\end{array}$ & $\begin{array}{c}\text { Existência de } \\
\text { leis } \\
\text { especificas } \\
\text { para proteção } \\
\text { ou controle } \\
\text { ambiental }\end{array}$ & $\begin{array}{l}\text { Existência de } \\
\text { ocupação } \\
\text { urbana em } \\
\text { área rural }\end{array}$ & $\begin{array}{l}\text { Loteamento } \\
\text { urbanos } \\
\text { aprovados } \\
\text { por lei } \\
\text { especial em } \\
\text { área rural }\end{array}$ & $\begin{array}{l}\text { Loteamento } \\
\text { s urbanos } \\
\text { sem } \\
\text { aprovação } \\
\text { em área } \\
\text { rural }\end{array}$ \\
\hline Suzano & Não & - & Não & - & - & - & Não & Não & Não & Não & Não & Sim & - & - \\
\hline
\end{tabular}

Fonte: [13] 


\subsection{Caracterização do meio aéreo}

O meio aéreo se relaciona com uma infinidade de variáveis complexas, como relevo, clima, vegetação e fenômenos atmosféricos.

Os parâmetros de qualidade ambiental podem ser definidos pelo monitoramento de variáveis consideradas principais, as quais são classificadas em dois grandes grupos de indicadores:

- Poluentes: dióxido de enxofre $\left(\mathrm{SO}_{2}\right)$, material particulado, óxidos de nitrogênio (NOx), ozônio $\left(\mathrm{O}_{3}\right)$ e oxidantes fotoquímicos, monóxido de carbono.

- Gases de efeito estufa (GEE): monóxido de carbono (emissivo), dióxido de carbono $\left(\mathrm{CO}_{2}\right)$, hidrocarbonetos $(\mathrm{HCs})$, metano $\left(\mathrm{CH}_{4}\right)$, óxido nitroso $\left(\mathrm{N}_{2} \mathrm{O}\right)$, substâncias destruidoras da camada de ozônio.

Em seguida, uma tabela com padrões nacionais de qualidade do ar fixados na Resolução CONAMA №03, de 28/06/90:

Tabela 31 - Padrões nacionais de qualidade do ar

\begin{tabular}{|c|c|c|c|c|}
\hline Poluente & Tempo de Amostragem & $\begin{array}{l}\text { Padrão Primário } \\
\mu \mathrm{g} / \mathrm{m}^{3}\end{array}$ & $\begin{array}{l}\text { Padrão Secundário } \\
\mu \mathrm{g} / \mathrm{m}^{3}\end{array}$ & Método de Medição \\
\hline \multirow{2}{*}{$\begin{array}{l}\text { partículas totais } \\
\text { em suspensão }\end{array}$} & 24 horas $^{1}$ & 240 & 150 & \multirow{2}{*}{$\begin{array}{l}\text { amostrador de } \\
\text { grandes volumes }\end{array}$} \\
\hline & $\mathrm{MGA}^{2}$ & 80 & $\begin{array}{r}150 \\
60\end{array}$ & \\
\hline \multirow{2}{*}{ partículas inaláveis } & 24 horas $^{1}$ & 150 & 150 & \multirow{2}{*}{$\begin{array}{c}\text { separação } \\
\text { inercial/filtração }\end{array}$} \\
\hline & $\mathrm{MAA}^{3}$ & 50 & 50 & \\
\hline \multirow{2}{*}{ fumaça } & 24 horas $^{1}$ & 150 & 100 & \multirow{2}{*}{ refletância } \\
\hline & $M A A^{3}$ & 60 & 40 & \\
\hline \multirow{2}{*}{ dióxido de enxofre } & 24 horas $^{1}$ & 365 & 100 & \multirow{2}{*}{ pararosanilina } \\
\hline & $\mathrm{MAA}^{3}$ & 80 & 40 & \\
\hline \multirow{3}{*}{ dióxido de nitrogênio } & 1 hora & 320 & 190 & \multirow{3}{*}{ quimiluminescência } \\
\hline & $\mathrm{MAA}^{3}$ & 100 & 100 & \\
\hline & 1 hora $^{1}$ & 40.000 & 40.000 & \\
\hline \multirow[t]{3}{*}{ monóxido de carbono } & & 35 ppm & $35 \mathrm{ppm}$ & \multirow{3}{*}{$\begin{array}{l}\text { infravermelho } \\
\text { não dispersivo }\end{array}$} \\
\hline & \multirow[t]{2}{*}{8 horas $^{1}$} & 10.000 & 10.000 & \\
\hline & & $9 \mathrm{ppm}$ & $9 \mathrm{ppm}$ & \\
\hline ozônio & 1 hora $^{1}$ & 160 & & 160 quimiluminescência \\
\hline
\end{tabular}

1 - Não deve ser excedido mais que uma vez ao ano.

2 - Média geométrica anual.

3 - Média aritmética anual.

Fonte: [44][2011] 
A CETESB publica também a qualidade do ar medido através de suas estações de monitoramento, onde se classifica a qualidade do ar através de um cálculo de índice de qualidade do ar (figura 46).

\begin{tabular}{|c|c|c|c|c|c|c|c|c|c|}
\hline Qualidade & Indice & $\begin{array}{c}\mathrm{MP}_{10} \\
\left(\mu \mathrm{g} / \mathrm{m}^{3}\right)\end{array}$ & $\begin{array}{c}0_{3} \\
\left(\mu g / m^{3}\right)\end{array}$ & $\begin{array}{c}\mathrm{CO} \\
(\mathrm{ppm})\end{array}$ & $\begin{array}{c}\mathrm{NO}_{2} \\
\left(\mu \mathrm{g} / \mathrm{m}^{3}\right)\end{array}$ & $\begin{array}{c}\mathrm{SO}_{2} \\
\left(\mu \mathrm{g} / \mathrm{m}^{3}\right)\end{array}$ & $\begin{array}{l}\text { Fumaça } \\
\left(\mu \mathrm{g} / \mathrm{m}^{3}\right)\end{array}$ & $\begin{array}{c}\text { PTS } \\
\left(\mu g / m^{3}\right)\end{array}$ & Significado \\
\hline $\mathrm{Boa}$ & 0.50 & 0.50 & $0-80$ & $0-4,5$ & $0-100$ & $0-80$ & $0-60$ & 0.80 & Praticamente não há riscos â saúde. \\
\hline Regular & $51-100$ & $>50-150$ & $>80-160$ & $>4,5-9$ & $>100-320$ & $>80-365$ & $>60-150$ & $>80-240$ & $\begin{array}{l}\text { Pessoas de grupos sensiveis } \\
\text { (crianças, idosos e pessoas com } \\
\text { doenças respiratórias e cardiacas) } \\
\text { podem apresentar sintomas como } \\
\text { tosse seca e cansaço. } \\
\text { A populaçāo, em geral, nâo é afetada. }\end{array}$ \\
\hline Inadequada & $101-199$ & $\begin{array}{l}>150 \text { e } \\
<250\end{array}$ & $\begin{array}{l}>160 e \\
<200\end{array}$ & $>9 e<15$ & $\begin{array}{l}>320 e \\
<1130\end{array}$ & $\begin{array}{l}>365 e \\
<800\end{array}$ & $\begin{array}{l}>150 e \\
<250\end{array}$ & $\begin{array}{l}>240 \text { e } \\
<375\end{array}$ & $\begin{array}{l}\text { Toda a população pode apresentar } \\
\text { sintomas como tosse seca, cansaço, } \\
\text { ardor nos olhos, nariz e garganta. } \\
\text { Pessoas de grupos sensiveis } \\
\text { (crianças, idosos e pessoas com } \\
\text { doenças respiratórias e cardiacas) } \\
\text { podem apresentar efeitos mais sérios } \\
\text { na saúde. }\end{array}$ \\
\hline Má & $200-299$ & $\begin{array}{l}\geq 250 \text { e } \\
<420\end{array}$ & $\begin{array}{l}\geq 200 e \\
<800\end{array}$ & $\begin{array}{l}\geq 15 \mathrm{e} \\
<30\end{array}$ & $\begin{array}{c}\geq 1130 \mathrm{e} \\
<2260\end{array}$ & $\begin{array}{l}\geq 800 \mathrm{e} \\
<1600\end{array}$ & $\begin{array}{l}\geq 250 \mathrm{e} \\
<420\end{array}$ & $\begin{array}{l}\geq 375 e \\
<625\end{array}$ & $\begin{array}{l}\text { Toda a população pode apresentar } \\
\text { agravamento dos sintomas como } \\
\text { tosse seca, cansaço, ardor nos olhos, } \\
\text { nariz e garganta e ainda apresentar } \\
\text { falta de ar e respiraçāo ofegante. } \\
\text { Efeitos ainda mais graves a saúde } \\
\text { de grupos sensiveis (crianças, } \\
\text { idosos e pessoas com problemas } \\
\text { cardiovasculares) }\end{array}$ \\
\hline Péssima & 2300 & $\geq 420$ & 2800 & 230 & $\geq 2260$ & $\geq 1600$ & 2420 & 2625 & $\begin{array}{l}\text { Toda a populaçäo pode apresentar } \\
\text { sérios riscos de manifestaçöes } \\
\text { de doenças respiratorias e } \\
\text { cardiovasculares. } \\
\text { Aumento de mortes prematuras em } \\
\text { pessoas de grupos sensiveis. }\end{array}$ \\
\hline
\end{tabular}

Figura 46 - Índice geral de qualidade do ar Fonte: [44] [2011]

No caso específico da região de estudo, a CETESB não dispõe de estações de medição da qualidade do ar. Como no município vizinho há estações manuais que disponibilizam dados relativos a fumaça e $\mathrm{SO}_{2}$, os dados dessas estações podem ser usados.(Obs.: medição de fumaça - o monitoramento foi interrompido devido à mudança de local, e a de $\mathrm{SO}_{2}$ foi desativada em 2009.) Seus resultados podem ser verificados nas tabelas 32 e 33. 
Tabela 32 - Fumaça (FMC)

\begin{tabular}{cccccccccc}
\hline & & & \multicolumn{1}{c}{ Máximas 24h } & \multicolumn{2}{c}{ No ultrapassagens } \\
Vocacional & UGRHI & Repres. & $\mathrm{N}$ & Média Aritm.ug/m3 & 1ㅇ ug/cm3 & 20 ug/cm3 & PQAr & AT & Ano \\
\hline \multirow{4}{*}{ Industrial } & & $\mathrm{R}$ & 58 & 18 & 58 & 49 & 0 & 0 & 2007 \\
& & $\mathrm{R}$ & 59 & 15 & 58 & 41 & 0 & 0 & 2008 \\
& & $\mathrm{R}$ & 53 & 12 & 35 & 29 & 0 & 0 & 2009 \\
& & $\mathrm{NR}$ & 16 & 15 & 31 & 24 & 0 & 0 & 2010 \\
\hline
\end{tabular}

Repres.=Indica se monitoramento foi representativo no ano (R) ou não (NR)

$\mathrm{N}=$ Número de dias válidos

Pqar=Padrão Nacional de qualidade do ar

Fonte: [44] [2011]

Tabela $33-\mathrm{SO} 2$

\begin{tabular}{ccccccccc}
\hline & & & \multicolumn{6}{c}{ Máximas 24h } \\
Vocacional & UGRHI & Repres. & $\mathrm{N}$ & Média Aritm.ug/m3 & 10 ug/cm3 & 20 ug/cm3 & Ano \\
\hline \multirow{3}{*}{ Industrial } & & $\mathrm{R}$ & 12 & 3 & 5 & 3 & 2007 \\
& 6 & $\mathrm{R}$ & 12 & 3 & 3 & 3 & 2008 \\
& & $\mathrm{R}$ & 12 & 3 & 3 & 3 & 2009 \\
\hline
\end{tabular}

Repres.=Indica se monitoramento foi representativo no ano (R) ou não (NR)

$\mathrm{N}=$ Número de dias válidos

Fonte: [44]

Há também as medições realizadas pela própria fábrica, que são disponibilizadas nos relatórios anuais, no site da empresa. Abaixo, os dados coletados de alguns relatórios:

Tabela 34 - Emissões de poluentes

\begin{tabular}{lcccccc}
\hline & \multicolumn{7}{c}{ Emissões de poluentes } \\
Ano/(toneladas) & 2005 & 2006 & 2007 & 2008 & 2009 & 2010 \\
\hline SOx(total) & 201 & 202 & 264 & 131 & 159,62 & 161,46 \\
NOx(total) & - & - & 506 & 729 & 1980,55 & $2070,88^{*}$ \\
Material particulado(total) & 310 & 309 & 281 & 322 & 236,87 & $256,89^{* *}$ \\
TRS(total) & 1,75 & 1,82 & 1,79 & 2,18 & 2,59 & 1,75 \\
\hline
\end{tabular}

*Foram incluídas novas caldeiras no sistema de amostragem

**Estimativa feita a partir da amostragem da CB3 de 2009 em razão de questionamentos em relação ao dado apurado em 2010

Com relação aos gases de efeito estufa, não há dados específicos para o município de Suzano. Existem apenas os dados relativos ao estado de São Paulo e 
os dados setoriais industriais, que podem ser visto na figura 47.

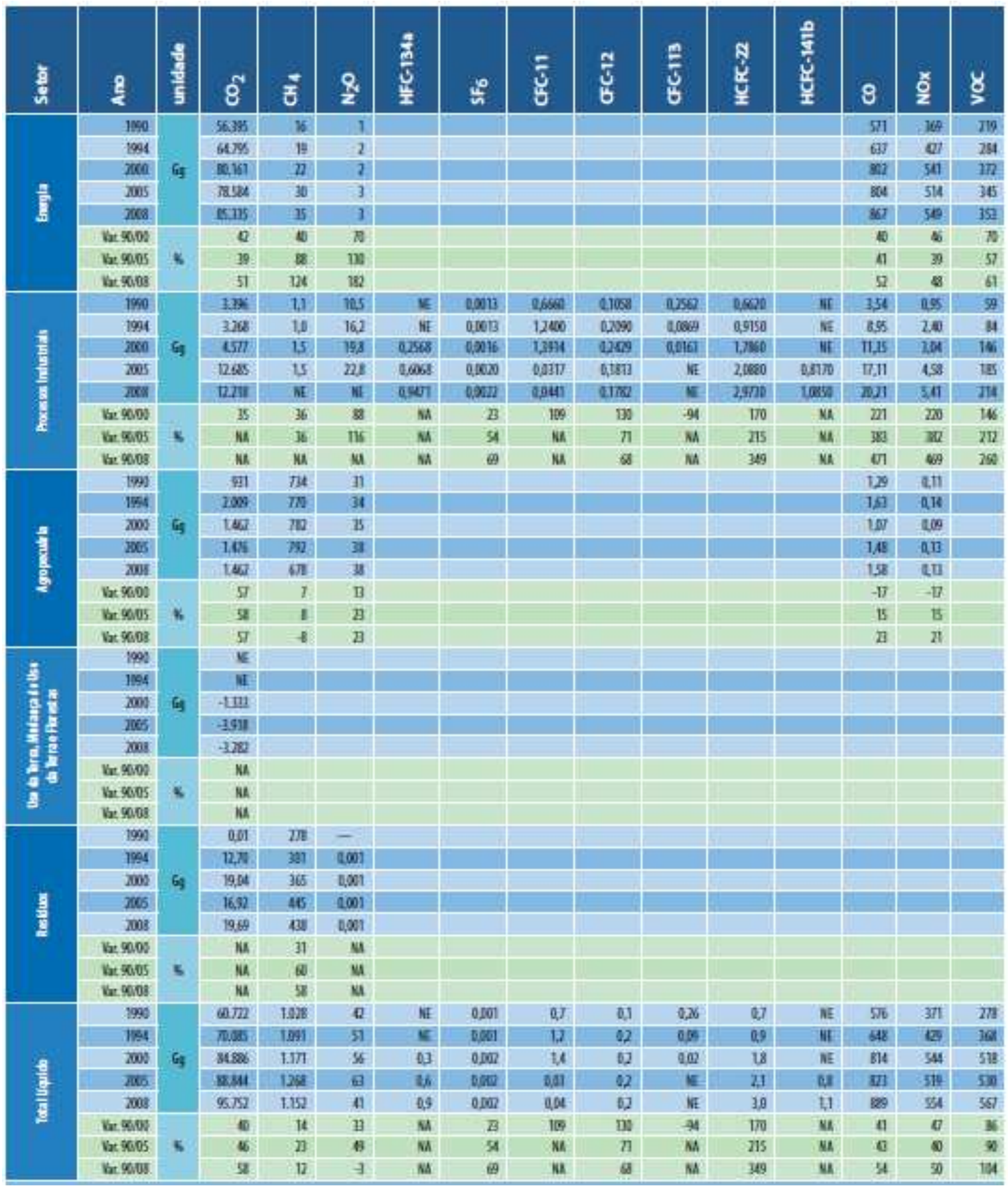

Figura 47 - Emissões e remoções de GEE do estado de São Paulo

Fonte: [45] [2011] 
A seguir temos um tabela das emissões de $\mathrm{CO}_{2}$ pelas indústrias de papel e celulose:

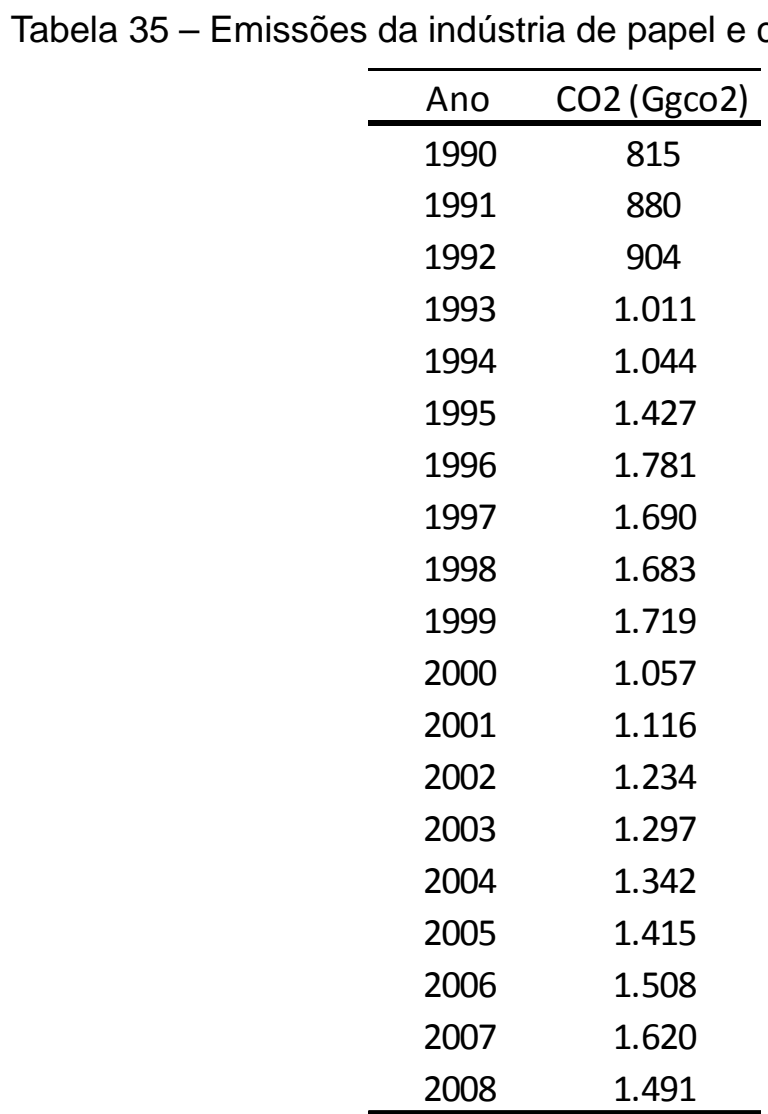

Fonte: [45] [2011]

Além disso a Suzano Papel e Celulose foi a primeira empresa no mundo a quantificar a Pegada Carbono em um dos seus produtos, obtendo o certificado de “Carbon Reduction Label”. A Pegada Carbono é uma terminologia designada para quantificar as emissões de GEE ocorridas ao longo do ciclo de vida de seus produtos, desde a matéria-prima até sua disposição final. Sendo assim, a empresa deve possuir dados relativos às emissões de GEE da unidade do município de Suzano, embora esses dados não tenham sido encontrados nos relatórios disponibilizados. 


\subsection{Caracterização do meio aquático}

O meio aquático é um sistema afetado não somente pelas interações no próprio meio, mas devido a influências do meio terrestre adjacente e ações antropogênicas.

O município de Suzano faz parte da UGRHI 6, que compreende 34 municípios e constitui-se em um dos maiores polos de riqueza nacional, além de responder por cerca de $15 \%$ do Produto Interno Bruto (PIB) brasileiro. O setor de serviços é o mais expressivo e mostra uma grande complementariedade com sua indústria. Na figura a seguir a demanda por setor na UGRHI 6.

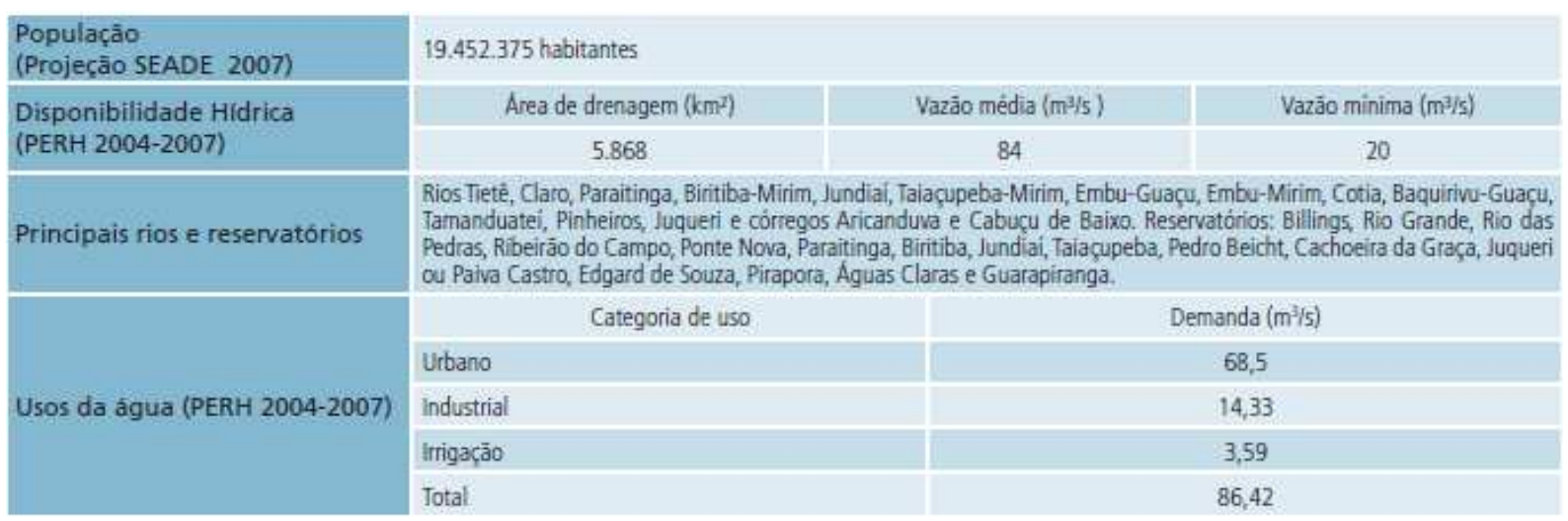

Figura 48 - Características da UGRHI

Fonte: [48][2008]

Os índices de qualidade de água, que são possíveis de obter através de relatórios da Companhia de Tecnologia de Saneamento Ambiental (CETESB), são importante fonte de dados. Neles, estão disponíveis índices como:

- IAP: Índice de qualidade de água bruta para fins de abastecimento público;

- IQA: Índice de qualidade de água;

- IVA: Índice de qualidade de água para a proteção da vida aquática.

Estes indicadores são mostrados nas figuras 49,50 e 51 .

Abaixo (tabela 36 e 37 ) temos os dados sobre o saneamento e pontos de monitoração do município de Suzano. 
Tabela 36 - Dados de saneamento básico do município de Suzano

\begin{tabular}{|c|c|c|c|c|c|c|c|c|c|c|c|}
\hline \multirow{2}{*}{ UGRHI } & \multirow{2}{*}{ Município } & \multirow{2}{*}{ Concessão } & \multicolumn{2}{|c|}{ População IBGE 210} & \multicolumn{2}{|c|}{ Atendimento (\%) } & \multirow{2}{*}{$\begin{array}{c}\text { Eficiência } \\
\qquad \%)\end{array}$} & \multicolumn{2}{|c|}{$\begin{array}{l}\text { Carga Poluidora } \\
\text { (kg DBO/dia) }\end{array}$} & \multirow{2}{*}{ ICTEM } & \multirow{2}{*}{ Corpo Receptor } \\
\hline & & & $\begin{array}{c}\text { População } \\
\text { Total }\end{array}$ & $\begin{array}{c}\text { População } \\
\text { Urbana }\end{array}$ & Coleta & Tratamento & & Potencial & Remanesc. & & \\
\hline 6 & Suzano & SABESP & 265.074 & 255.746 & 82 & 70 & 94 & 13.810 & 6.359 & 5,99 & Rio Tietê \\
\hline
\end{tabular}

Fonte: [46]

Tabela 37 - Pontos de medição do município de Suzano

\begin{tabular}{|c|c|c|c|c|c|}
\hline Corpo Hídrico & Cód.CETESB & Topo.Mon & Local de Amostragem & Lat. $\mathrm{S}$ & Long.W \\
\hline \multirow[t]{2}{*}{ Res.Taiaçupeba } & PEBA 00900 & $\mathrm{RB}$ & Na captação da SABESP & 233445 & 461718 \\
\hline & & & A jusante do vertedouro do Reservatório de & & \\
\hline Rio Taiaçubeba-Mirim & TAIA 02800 & $\mathrm{RB}$ & $\begin{array}{l}\text { Taiaçubeba e montante da Indústria de papel e } \\
\text { celulose Suzano }\end{array}$ & 233418 & 461727 \\
\hline Rio Taiaçubeba-Açu & TAIM 00800 & RB & $\begin{array}{l}\text { Ponte na estrada Pau a Pique com Estrada } \\
\text { Boraceia, próximo de EEE Jardim Planalto }\end{array}$ & 233804 & 461917 \\
\hline Rio Tietê & TIET 03120 & RB & A jusante da ETE de Suzano & 233011 & 462013 \\
\hline
\end{tabular}

Fonte: [36]

\begin{tabular}{|l|c|c|c|c|c|c|c|}
\hline \multicolumn{1}{|c|}{ Corpo Hidrico } & Ponto & 2006 & 2007 & 2008 & 2009 & 2010 & 2011 \\
\hline Reservatório Taiaçupeba & PEBA00900 & 87 & 87 & 88 & 80 & 81 & 85 \\
\hline Rio Taiaçupeba-Açu & TAIA02800 & & & & 77 & 78 & 79 \\
\hline Rio Taiaçupeba-Mirim & TAIM00800 & & & & 42 & 46 & 42 \\
\hline Rio Tietê & TIET03120 & 25 & 30 & 24 & 28 & 33 & 32 \\
\hline
\end{tabular}

\section{Legenda: $\quad$ Ótima $\quad$ Boa $\square$ Regular $\square$ Ruim $\square$ Péssima}

Figura 49 - Índice IQA

Fonte: [46]

\begin{tabular}{|l|c|c|c|c|c|}
\hline \multicolumn{1}{|c|}{ Corpo Hidrico } & Ponto & 2006 & 2009 & 2010 & IAP 2011 \\
\hline Reservatório Taiaçupeba & PEBA00900 & & & 54 & 71 \\
\hline
\end{tabular}

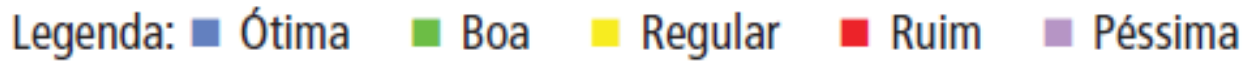

Figura 50 - Índice IAP

Fonte: [46] 


\begin{tabular}{|c|c|c|c|c|c|c|c|}
\hline Corpo Hidrico & Ponto & 2006 & 2007 & 2008 & 2009 & 2010 & IVA 2011 \\
\hline Reservatório Taiaçupeba & PEBA00900 & & & & & & 4,5 \\
\hline Rio Taiaçupeba-Mirim & TAIM00800 & & & & & & 4,4 \\
\hline
\end{tabular}

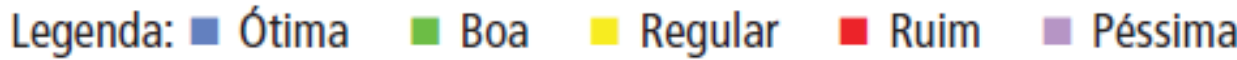

Figura 51 - Índice IVA

Fonte: [46]

Também existem informações sobre a interferência desta indústria no corpo hídrico do município, que podem ser vistos na tabelas 38 e 39.

Tabela 38 - Consumo de água do rio Tietê

\begin{tabular}{cc}
\multicolumn{3}{c}{ Consumo de Água } \\
\hline Ano & $\left(\mathrm{m}^{3}\right)$ \\
\hline 2005 & 25.993 .000 \\
2006 & 26.739 .928 \\
2007 & 28.780 .680 \\
2008 & 27.950 .700 \\
2009 & 24.108 .936 \\
2010 & $24.342 .846^{* *}$ \\
\hline
\end{tabular}

**Inclui Taiaçupeba

Fonte: [47] [2011]

Tabela 39 - Efeito do consumo de água na vazão do rio

\begin{tabular}{cccc}
\hline Ano & $\begin{array}{c}\text { Vazão do } \\
\text { Rio } \\
\mathrm{m}^{3} / \mathrm{h}\end{array}$ & $\begin{array}{c}\text { Consumo } \\
\text { de Água } \\
\mathrm{m}^{3} / \mathrm{h}\end{array}$ & $\begin{array}{c}\% \text { de } \\
\text { retirada } \\
\%\end{array}$ \\
\hline 2006 & 43.200 & 3.060 & 7,08 \\
2007 & 38.106 & 3.050 & 7,99 \\
2008 & 41.400 & 3.190 & 7,71 \\
2009 & 91.067 & 2.752 & 3,03 \\
2010 & 114.000 & 2.770 & 2,44 \\
\hline
\end{tabular}

Fonte: [47] [2011]

E, na demanda de água por UGRHI, pode-se notar(figura 52) que a situação nos municípios que compõem a UGRHI 6 é crítica. (Cor vermelha significa crítico,amarela é estado de atenção e verde é estado bom). 


\begin{tabular}{|c|c|c|c|c|c|}
\hline \multirow{2}{*}{ UGRHI } & \multirow{2}{*}{$\begin{array}{c}\text { Disponibilidade } \\
\text { hidrica total }\left(\mathrm{m}^{3 / s}\right)\end{array}$} & \multicolumn{2}{|c|}{ Demanda total $\left(\mathrm{m}^{3} / \mathrm{s}\right)$} & \multicolumn{2}{|c|}{$\begin{array}{c}\text { Demanda/ } \\
\text { Disponibilidade (\%) }\end{array}$} \\
\hline & & 2007 & 2008 & 2007 & 2008 \\
\hline 01 - Mantiqueira & 10 & 0,68 & 0,68 & 6,77 & 6,77 \\
\hline 02 - Paraíba do Sul & 93 & 12,79 & 14,02 & 13.75 & 15,07 \\
\hline 03 - Litoral Norte & 39 & 0,68 & 1,40 & 1,74 & 3,59 \\
\hline 04 -Pardo & 44 & 10,56 & 13.53 & 23,99 & 30,75 \\
\hline P5-Piracicaba/Capivari/Jundiaí & 65 & 78,94 & 81,10 & 121,44 & 124,77 \\
\hline 06 -Alto Tietê & 31 & 49,10 & 54,63 & 158,37 & 176,23 \\
\hline 07- Baixada Santista & $5^{8}$ & 18,17 & 18,21 & 31,33 & 31,40 \\
\hline 08 -Sapucai/Grande & 46 & 4,80 & 5,10 & 10,43 & 11,10 \\
\hline 09 - Mogi-Guaçu & 72 & 18,87 & 18,86 & 26,21 & 26,20 \\
\hline 10 -Sorocaba/Médio Tietê & 39 & 10,47 & 12,39 & 26,84 & 31,76 \\
\hline 11 - Ribeira de Iguape/Litoral Sul & 229 & 1,95 & 3,13 & 0,85 & 1,37 \\
\hline 12 - Baixo Pardo/Grande & 31 & 11,52 & 12,32 & 37,16 & 39,76 \\
\hline 13-Tietê/Jacaré & 50 & 16,19 & 24,23 & 32,38 & 48,46 \\
\hline 14-Alto Paranapanema & 114 & 6,78 & 9,96 & 5,94 & 8,74 \\
\hline 15 -Turvo/Grande & 39 & 14,89 & 16,72 & 38,18 & 42,86 \\
\hline 16 - Tietê/Batalha & 40 & 7,97 & 8,47 & 19,93 & 21,17 \\
\hline 17 - Médio Paranapanema & 82 & 6,26 & 8,02 & 7,63 & 9.77 \\
\hline 18 - São José dos Dourados & 16 & 4,99 & 5,16 & 31,20 & 32,23 \\
\hline 19-Baixo Tietê & 36 & 3,12 & 4,30 & 8,66 & 11,95 \\
\hline 20 - Aguapei & 41 & 3,35 & 3,40 & 8,16 & 8,30 \\
\hline 21 -Peixe & $3^{8}$ & 1,61 & 2,18 & 4,24 & 5.74 \\
\hline 22 - Pontal do Paranapanema & 47 & 0,83 & 1,37 & 1,77 & 2,91 \\
\hline ESTADO DE SÃO PAULO & 1259 & 284,50 & 319,18 & 22,60 & 25,35 \\
\hline
\end{tabular}

Figura 52 - Balanço hídrico por UGRHI

Fonte: SMA/CRHi (2010), elaborado por SMA/CPLA (2010) [49]

Tabela 40 - Carga orgânica poluidora - Doméstica

\begin{tabular}{llllllllll}
\hline \multirow{2}{*}{ Concessão População IBGE 2008} & \multicolumn{2}{c}{ Atendimento (\%) } & Eficiencia & $\begin{array}{c}\text { Carga Poluidora } \\
\text { (kg DBO/dia) }\end{array}$ & ICTEM & $\begin{array}{c}\text { Corpo } \\
\text { Receptor }\end{array}$ \\
& Total & Urbana & Coleta & Tratam. & $\%$ & Potencial Remanesc. & \\
\hline Sabesp & 279.394 & 270.516 & 82 & 70 & 81 & 14.608 & 7.816 & 5,5 Rio tietê \\
\hline
\end{tabular}

Fonte: [48][2008]

Para o caso das águas subterrâneas em 2009, foi instituído o Indicador de Portabilidade das Águas Subterrâneas (IPAS), que representa o percentual das amostras coletadas em conformidade com os padrões de potabilidade e de aceitação 
ao consumo humano, de acordo com a Portaria do Ministério de Saúde nº 518/04.

Tabela 41 - Indicador de potabilidade das águas subterrâneas

\begin{tabular}{|c|c|c|c|c|c|c|}
\hline UGRHI & IPAS(\%) & $\begin{array}{l}2007 \\
\text { Parâmentros em não } \\
\text { conformidade }\end{array}$ & IPAS(\%) & $\begin{array}{l}2008 \\
\text { Parâmentros em não } \\
\text { conformidade }\end{array}$ & IPAS(\%) & $\begin{array}{l}2009 \\
\text { Parâmentros em não } \\
\text { conformidade }\end{array}$ \\
\hline 6-Alto Tiete & 62,3 & $\begin{array}{c}\text { alumínio, crômio, } \\
\text { ferro, } \\
\text { fluoreto,manganês, } \\
\text { nitrato, coliformes } \\
\text { totais, bactérias } \\
\text { heterotróficas }\end{array}$ & 56,3 & $\begin{array}{c}\text { alumínio, chumbo, } \\
\text { ferro,fluoreto, mangan } \\
\text { ês, nitrato, } \\
\text { bactérias, heterotrófica } \\
\text { s e coliformes totais }\end{array}$ & 79,5 & $\begin{array}{c}\text { alumínio, ferro, fluoreto, } \\
\text { manganês, nitrato, } \\
\text { bactérias heterotróficas, } \\
\text { coliformes totais }\end{array}$ \\
\hline
\end{tabular}

Fonte: CETESB (2010a), elaborado por SMA/CPLA (2010) [49]

\subsection{Caracterização do meio terrestre}

Considera-se como meio terrestre todo o espaço da superfície e do subsolo. É composto de formações geomorfológicas que constituem o solo, formações vegetais, espécies de animais naturais, além de seu uso em divisões políticas e estratégias, culturas agrícolas e mineração.

A seguir, pode-se ver a área de vegetação nativa da UGRHI 6. Essas variações se devem ao fato de que o inventário de 2008/2009 foi produzido com imagens de satélite de alta resolução, que resultou na descoberta de novos fragmentos florestais que não estavam contabilizadas no mapeamento anterior.

Tabela 42- Área de vegetação nativa por UGRHI em 2005 e 2008/2009

\begin{tabular}{cccccc}
\hline UGRHI & \multicolumn{4}{c}{ Ano } & \multicolumn{2}{c}{$\begin{array}{c}\text { Variação } \\
\text { (ha) }\end{array}$} \\
& Área (ha) \% & Área (ha) \% & (ha) \\
\hline 06-Alto Tiete & 181.149 & 27,25 & 220.658 & 39,1 & 39.509 \\
\hline
\end{tabular}

Fonte: Kronka et al (2005) e IF (2010), elaborado por SMA/CPLA (2010) [49]

O indicador a seguir é constituído pela porcentagem da área de mata ciliar em relação às áreas totais dos proprietários em que se localizam a mata. Esses dados 
fornecerão subsídios para a elaboração de projetos de recuperação florestal.

Tabela 43 - Área de mata ciliar declarada no estado de São Paulo por UGRHI até 2010

\begin{tabular}{ccccc}
\hline UGRH & $\begin{array}{c}\text { Número de } \\
\text { Áreas }\end{array}$ & $\begin{array}{c}\text { Áreas das } \\
\text { propriedades (ha) }\end{array}$ & $\begin{array}{c}\text { Área ciliar } \\
\text { declarada (ha) }\end{array}$ & $\%$ \\
\hline 06-Alto Tiete & 20 & $21.571,19$ & $3.991,77$ & $18,50 \%$ \\
\hline
\end{tabular}

Fonte: SMA/PAE Mata Ciliar (2010), elaborado por SMA/CPLA (2010) [49]

Os contaminantes são caracterizados por serem todos os compostos químicos que podem ser encontrados no solo, decorrentes das atividades humanas ou por efeitos de fenômenos da natureza (por exemplo, vulcões). Pode-se verificar que ano a ano a quantidade de áreas contaminadas vem crescendo (tabela 44), o que torna o monitoramento desse indicador importante. Além disso, há riscos de contaminação do lençol freático, entre outros efeitos negativos.

Tabela 44 - Número de áreas contaminadas cadastradas no estado de São Paulo

\begin{tabular}{crrrrr}
\hline \multirow{2}{*}{ UGRHI } & \multicolumn{5}{c}{ Número de Áreas Contaminadas } \\
& nov/05 & nov/06 & nov/07 & nov/08 & nov/09 \\
\hline 06-Alto Tiete & 820 & 961 & 1175 & 1260 & 1335 \\
\hline
\end{tabular}

Fonte: CETESB (2010f), elaborado por SMA/CPLA (2010) [49]

Pode-se notar que a grande quantidade de áreas contaminadas está relacionada a postos de combustíveis (tabela 45). Isto se deve em grande parte à resolução COANMA no 237/00, que estabeleceu a obrigatoriedade de licenciamento para essa atividade, permitindo melhor monitoramento.

Tabela 45 - Número de áreas contaminadas cadastradas no estado de São Paulo e por tipo de atividade em 2009

\begin{tabular}{ccccccc}
\hline UHRHI & Comercial & Industrial & Resíduos & $\begin{array}{c}\text { Atividade } \\
\text { Postos de } \\
\text { Combustíveis }\end{array}$ & $\begin{array}{c}\text { Acidentes/ } \\
\text { Desconhecida }\end{array}$ & Total \\
\hline 06-Alto Tiete & 55 & 189 & 41 & 1043 & 7 & 1335 \\
\hline
\end{tabular}

Fonte: CETESB (2010f), elaborado por SMA/CPLA (2010) [49]

Com o objetivo de melhorar e facilitar o gerenciamento das áreas contaminadas, 
a CETESB as classificou em quatro tipos em função do nível de informação ou dos riscos existentes em cada uma. Esses índices mostram uma melhora significativa nos números do estado de São Paulo, de 7,2\%, em 2008, para 34,8\%, em 2009.

Tabela 46 - Índice de reabilitação e classificação das áreas contaminadas em 2009

\begin{tabular}{ccccccc}
\hline \multirow{2}{*}{ UGRHI } & Al & AC & AMR & AR & Total & Reabilitação (\%) \\
\hline 06-Alto Tiete & 194 & 676 & 403 & 62 & 1335 & 34,8 \\
\hline
\end{tabular}

Legenda: Al: área contaminada sob investigação; AC: área contaminada;

AMR: área em processo de monitoramento para reabilitação;

AR: área reabilitadapara o uso declarado; Índice de Reabilitação $=(A M R+A R) /$ total de áreas $) * 100$

Fonte: CETESB (2010f), elaborado por SMA/CPLA (2010) [49]

Em 2010, houve a maior concentração de óbitos na UGRHI 6, com 23 mortes (tabela 47), num total de 42 do estado de São Paulo.

Tabela 47 - Distribuição dos acidentes relacionados a desastres naturais por tipo e consequência em 2010

\begin{tabular}{|c|c|c|c|c|c|c|c|c|c|c|}
\hline \multirow{2}{*}{ UGRHI } & \multicolumn{5}{|c|}{ Tipo de acidente } & \multirow[t]{2}{*}{$F$} & \multicolumn{4}{|c|}{ Tipo de dano } \\
\hline & $A$ & B & C & $\mathrm{D}$ & $E$ & & G & $\mathrm{H}$ & 1 & $\mathrm{~J}$ \\
\hline 06-Alto Tiete & 88 & 32 & 60 & 0 & 43 & 135 & 23 & 1188 & 1988 & 3176 \\
\hline
\end{tabular}

Fonte: Cedec (2010) [49] 


\section{Previsão de demanda e cenário}

O objetivo é de construir um cenário energético, dentro do Planejamento Integrado de Recursos Energéticos, e validar o Plano Preferencial de Recursos Energéticos, modelando as demandas, impactos ambientais, sociais e econômicos resultantes do planejamento proposto (GIMENES, 2004).

Com ele, é possível analisar a consistência do planejamento ao longo de seu horizonte de tempo, verificando se os recursos energéticos atendem às necessidades ao longo do tempo. Um cenário energético está intimamente ligado a um cenário socioeconômico, podendo satisfazer a demanda de diferentes maneiras, fontes e usos finais. Ela não é simplesmente uma extrapolação de dados em tempos passados.

O horizonte de planejamento deve considerar um prazo superior a 15 anos (longo prazo), para que não se torne apenas um trabalho descritivo. Existem três tipos de cenários [42]:

- Cenário tendencial: são aqueles que utilizam índices e dados históricos para construção do ano base e seus prolongamentos na linha do tempo.

- Cenário preditivos: são aqueles em que há possibilidade de analisar a interferência de uma ou mais ações que devem ser tomadas ao longo do planejamento.

- Cenários exploratórios: são aqueles em que há a possibilidade de modificar a relação entre as variáveis que compõem o sistema e verificar os resultados devido a essas mudanças.

Para este trabalho, considera-se o cenário tendencial, uma vez que este é o que mais se aproxima das necessidades de um ambiente corporativo. 


\subsection{Cenário tendencial}

Para este cenário, necessita-se de dados estatísticos para construir as projeções. Também serão utilizados dados econômicos do setor de papel e celulose, de modo que as tendências não sejam fruto de meras projeções de dados históricos.

Durante o período de 2008 a 2010, o Brasil foi o único país em que a produção de celulose cresceu, com uma elevação de 5,6\% em relação a 2009, chegando a 14,1 milhões de toneladas anuais, e uma elevação de 3,9\% do volume de produção de papel [40]. Em 2011, a produção de celulose se manteve estável. Em 2012 há incertezas devido ao momento negativo da economia europeia e aos sinais de desaceleração na China, os dois maiores mercados globais para a celulose brasileira.

Segundo avaliação da consultoria Pöiry, a demanda mundial de celulose deve crescer em torno de $3 \%$ ao ano até o ano de 2023 , enquanto a demanda por papel deve aumentar em torno de $1,5 \%$ [40].

Abaixo temos uma figura que mostra a expectativa de crescimento de demanda de celulose(figura 53) e por produto (figura 54).

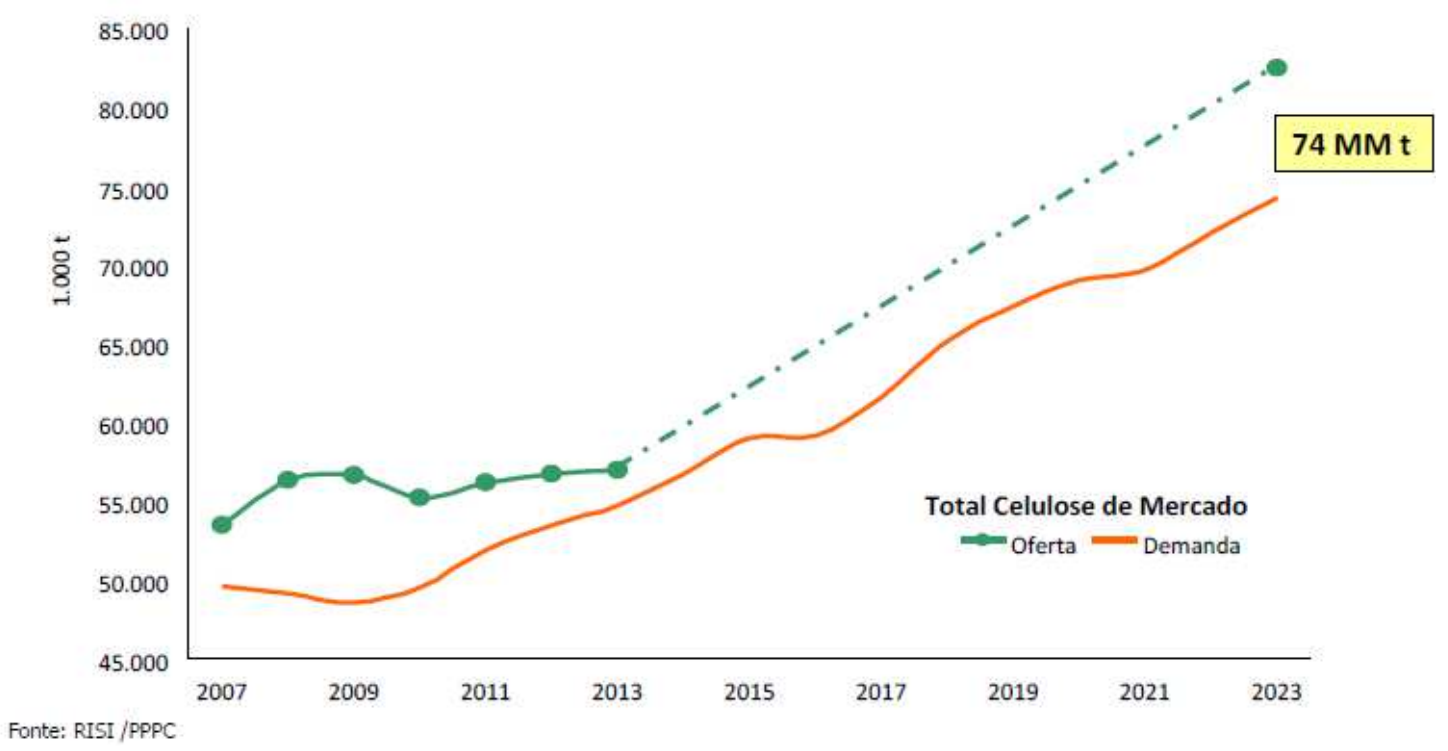

Figura 53 - Expectativa de crescimento de demanda de celulose

Fonte: [43] 


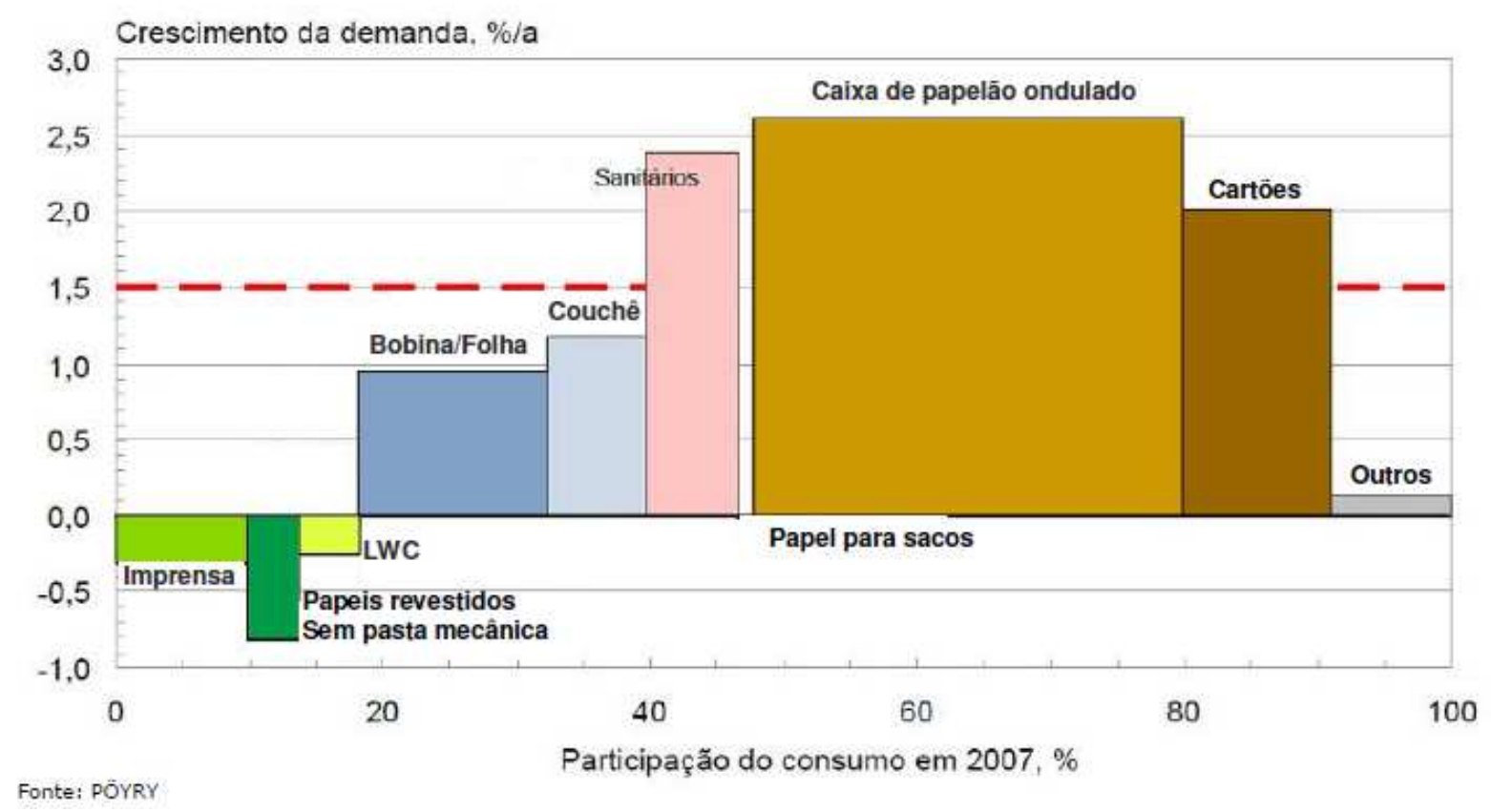

Figura 54 - Perspectiva de crescimento por produto

Fonte: [43]

As operações industriais na Suzano Papel e Celulose são geridas visando a redução do consumo de energia e a autossuficiência com relação à geração de energia. Em outra unidade do mesmo grupo, em torno de $98 \%$ da energia consumida é produzida internamente. Melhorias e novas tecnologias no processo produtivo também colaboram para a redução do consumo de energia.

$\mathrm{Na}$ figura 55 podemos verificar um gráfico motrando o consumo de energia na unidade de Suzano. 


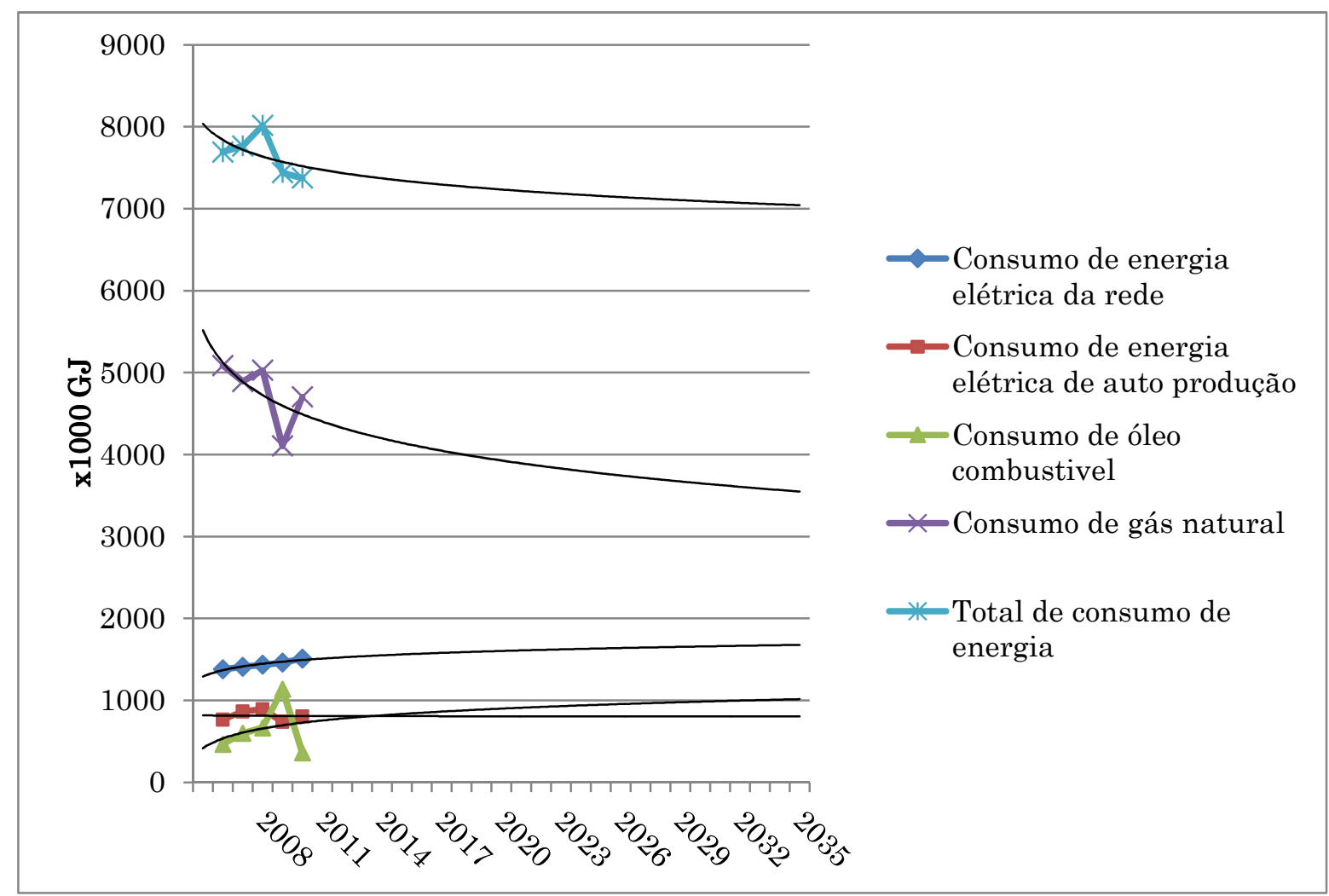

Figura 55 - Gráfico de consumo de energia na unidade de Suzano e suas projeções Fonte: Elaboração própria, a partir de relatórios

Graças a essas medidas e devido ao fato que a análise se foca em uma unidade específica, com capacidade de produção limitada, embora haja um crescimento da demanda de celulose, a previsão de consumo total de energia tem uma tendência a estabilização a longo prazo(figura 55). A limitação também se deve ao fato de que a demanda de energia é planejada de acordo com a capacidade de produção da fábrica. Se não houver um aumento de capacidade não irá ocorrer uma aumento significativo no consumo de energia elétrica.

Para maior precisão da previsão de demanda de energia elétrica seria necessário uma melhor estratificação das informações. Devido à falta de informações mais detalhadas, isto não foi possível. 
A seguir, pode-se ver a previsão de consumo em MWh.

\begin{tabular}{|c|c|}
\hline Ano & $\begin{array}{c}\text { Consumo } \\
\text { (MWh) }\end{array}$ \\
\hline 2006 & 594.862 \\
\hline 2008 & 645.487 \\
\hline 2010 & 642.320 \\
\hline 2012 & 644.000 \\
\hline 2014 & 650.000 \\
\hline 2016 & 657.000 \\
\hline 2018 & 662.000 \\
\hline 2020 & 666.000 \\
\hline 2022 & 670.000 \\
\hline 2024 & 673.000 \\
\hline 2026 & 676.000 \\
\hline 2028 & 680.000 \\
\hline 2030 & 682.000 \\
\hline 2032 & 685.000 \\
\hline 2034 & 687.000 \\
\hline 2035 & 688.000 \\
\hline
\end{tabular}

Fonte: Elaboração própria 


\section{Plano Preferencial Integrado dos Recursos Energéticos}

\subsection{Atendimento da demanda}

Nesta etapa, procura-se distribuir os recursos ao longo do horizonte de planejamento de acordo com o menor custo completo. Os recursos são alocados ao longo do período planejado conforme as capacidades de energia realizáveis em seu respectivo setor e potencial no ano, respeitando-se a classificação dos recursos obtida no Ranqueamento e no cenário energético elaborado (tabela 49). Nenhum recurso deve ser descartado, pois no PIR são consideradas ainda variáveis temporárias, geográficas, políticas e a disponibilidade do recurso, podendo ocorrer que um recurso que no início do planejamento se encontrava em um ranking menor se torne viável num outro determinado tempo devido às outras variáveis.

$\mathrm{Na}$ tabela a seguir podemos verificar que para a demanda do ano de 2006 foram utilizados os recursos de hidroeletricidade à caldeira de recuperação, conforme a classificação obtida no ranqueamento. Para o atendimento do incremento da demanda para os anos seguintes, somente a caldeira de recuperação foi utilizada.

Tabela 49 - Recursos de oferta x Incremento da demanda (MWh)

\begin{tabular}{|c|c|c|c|c|c|c|c|c|c|c|c|}
\hline & 2006 & 2008 & 2010 & 2012 & 2014 & 2016 & 2018 & 2022 & 2026 & 2030 & 2035 \\
\hline Incremento da demanda & 594.862 & 50.625 & -3.167 & 1.680 & 6.000 & 7.000 & 5.000 & 8.000 & 6.000 & 6.000 & 6.000 \\
\hline Hidro & 387.630 & 0 & 0 & 0 & 0 & 0 & 0 & 0 & 0 & 0 & 0 \\
\hline l/Óleo & 96.184 & 0 & 0 & 0 & 0 & 0 & 0 & 0 & 0 & 0 & 0 \\
\hline Calde & 51.158 & 0 & 0 & 0 & 0 & 0 & 0 & 0 & 0 & 0 & 0 \\
\hline Caldeira de recuperação & 59.890 & 50.625 & -3.167 & 1.680 & 6.000 & 7.000 & 5.000 & 8.000 & 6.000 & 6.000 & 6.000 \\
\hline Gaseificador Licor Negro & 0 & 0 & 0 & 0 & 0 & 0 & 0 & 0 & 0 & 0 & 0 \\
\hline
\end{tabular}

Fonte: Elaboração própria

\subsection{Indicadores de restrição (vigilantes)}

Para que a distribuição dos recursos seja realizada de forma eficiente e adequada, são necessários indicadores de restrições. Esses indicadores poderão definir a 
entrada ou não do recurso. Para este trabalho, os indicadores foram os seguintes:

- Disponibilidade hídrica: este vigilante corresponde ao consumo de água que cada recurso consome.

- Impactos na economia: este vigilante verifica o impacto que determinado recurso impões à região onde será implementado.

- Impacto no processo produtivo: este vigilante verifica se o recurso tem algum impacto no processo produtivo. Ele é muito importante, pois se o recurso impactar de alguma forma o processo produtivo, o investimento empresarial pode se tornar inviável.

- Emissões de GEE: verifica as emissões que determinado recurso pode gerar.

- Crescimento populacional: verifica o impacto de determinado recurso na população local.

- Grau de urbanização: verifica os impactos na infraestrutura na região estudada

- Material particulado: verifica as emissões de material particulado que cada recurso emite.

\subsection{Integração dos Recursos Energéticos}

A Figura a seguir mostra o alocamento de recursos em função do incremento de demanda de energia já com a atuação dos vigilantes. 


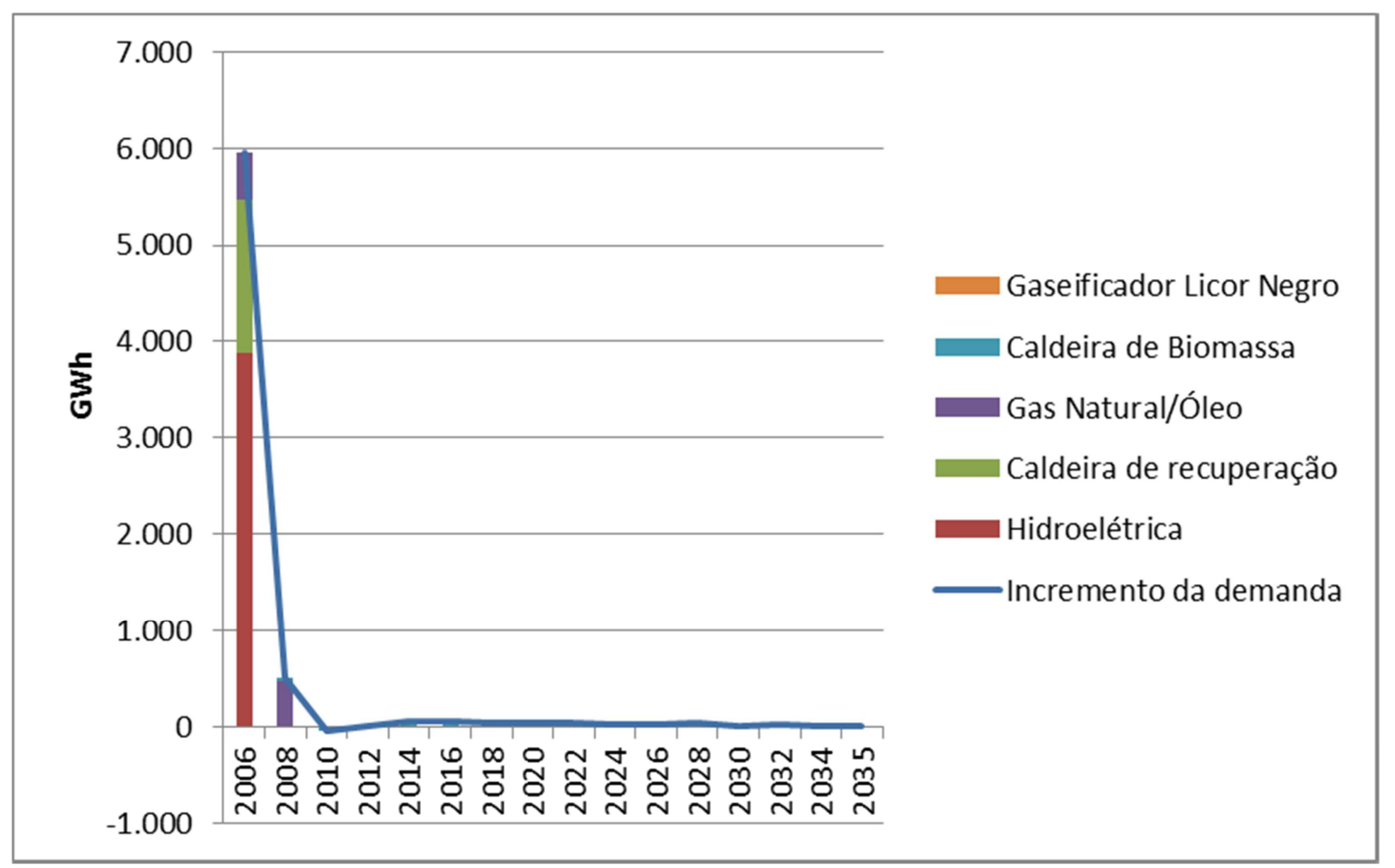

Figura 56 - Gráfico dos recursos da oferta para atendimento do incremento de demanda energética (GWh)

Considera-se que a planta irá iniciar as operações em 2006. Neste primeiro ano, utilizaram-se toda capacidade dos recursos de hidroeletricidade, caldeira de recuperação e parte da caldeira de gás/óleo. A caldeira de recuperação, embora tenha sido classificada em terceiro no ranqueamento, está entrando como segundo recurso devido à atuação dos vigilantes (impacto no processo produtivo). Numa empresa de papel e celulose, é essencial a operação dessa caldeira para o funcionamento do processo produtivo como um todo.

No ano de 2010, pode-se verificar uma queda na demanda energética (tabela 50). Isto resultou na "devolução"(valores negativos) de parte dos recursos energéticos.

A partir de 2008, verifica-se que o recurso caldeira de biomassa atende aos crescimentos posteriores de demanda energética até o final do tempo de estudo.

Verifica-se pela tabela 50 seguinte que ocorreu a concorrência entre os 
recursos. A caldeira de recuperação utiliza a mesma fonte (licor negro) que o gaseificador de licor. Dessa forma, enquanto utilizou-se a caldeira de recuperação como recurso, o gaseificador de licor não poderá ser utilizado. Pode-se ver também que mesmo após a vida útil das caldeiras, elas continuam sendo utilizadas, isto ocorre porque, na prática, de tempos em tempos, as caldeiras sofrem upgrade e recuperação, aumentando assim sua vida útil.

Tabela 50 - Recursos da oferta x Incremento da demanda (MWh)

\begin{tabular}{|c|c|c|c|c|c|c|c|c|c|c|c|}
\hline & 2006 & 2008 & 2010 & 2012 & 2014 & 2016 & 2018 & 2022 & 2026 & 2030 & 2035 \\
\hline Incremento da demanda & 594.862 & 50.625 & -3.167 & 1.680 & 6.000 & 7.000 & 5.000 & 8.000 & 6.000 & 6.000 & 6.000 \\
\hline Hidro & 387.630 & 0 & 0 & 0 & 0 & 0 & 0 & 0 & 0 & 0 & 0 \\
\hline de recuperação & 159.677 & 0 & 0 & 0 & 0 & 0 & 0 & 0 & 0 & 0 & 0 \\
\hline Gas Natural/Óleo & 47.555 & 48.629 & -1.171 & 509 & 0 & 0 & 0 & 0 & 0 & 0 & 0 \\
\hline Caldeira de Biomassa & 0 & 1.996 & -1.996 & 1.171 & 6.000 & 7.000 & 5.000 & 8.000 & 6.000 & 6.000 & 6.000 \\
\hline Gaseificador Licor Negro & 0 & 0 & 0 & 0 & 0 & 0 & 0 & 0 & 0 & 0 & 0 \\
\hline
\end{tabular}

Fonte: Elaboração própria

\subsection{Plano preferencial}

Os recursos energéticos analisados em 2006 destinados ao atendimento da demanda energética estão listados na tabela 51 a seguir:

Tabela 51 - Tabela preferencial de recursos

\begin{tabular}{cl}
\hline Ano & Plano de Recursos Energéticos (RELO) \\
\hline 2006 & HID, CR, GNO \\
2008 & GNO,CB \\
2018 & CB \\
2022 & CB \\
2026 & CB \\
2030 & CB \\
2035 & CB \\
\hline
\end{tabular}

Legenda: HID - Hidroelétrica, CR - Caldeira de Recuperação, GNO - Caldeira de Gás natural/óleo, CB - Caldeira de Biomassa

No primeiro ano de funcionamento, é possível atender a demanda somente com energia hidroelétrica, caldeira de recuperação e caldeira a gás/óleo. A partir de 2008 foi incluído o recurso de caldeira de biomassa, que irá atender toda demanda até o final do período de Planejamento em 2036. 


\section{Conclusão}

Pode-se verificar que praticamente todos os recursos são utilizados nos primeiros anos de operação e que, durante o período avaliado, não foi necessária a inclusão de novo recurso pois o acrescimo de demanda foi atendida com os recursos já alocados. Com isso no planejamento não foi utilizado o recurso "gaseificador de licor negro".

Para o cenário e vigilantes escolhidos para esta dissertação, o recurso "gaseificador de licor negro" não se mostrou viável. Mas se alterássemos as variáveis, por exemplo um cenário mais ecológico, ou se incluíssemos novos vigilantes, como por exemplo um tomador de decisão que aposte em inovações tecnológicas, que determine a entrada do gaseificador de licor o planejamento poderia ser outro.

Neste trabalho somente analisamos os Recursos Energéticos do Lado a Oferta (RELOs), mas para uma aplicação completa em um ambiente empresarial, seria interessante analisamos também os Recursos Energético do Lado da Demanda (RELDs). Isto devido que cada vez mais as empresas buscam a diminuir o consumo de energia elétrica através de medidas de eficiência energética, diminuindo os desperdícios no processo produtivo e administrativo. Tornado o PIR uma ferramenta interessante para o planejamento energético de uma empresa visando um desenvolvimento sustentável. 


\section{Referências Bibliográficas}

[1] Larson, E.D.; Consonni, S. S.; Katofsky, R.E. A Cost-Benefit Assessment of Biomass Gasification Power Generation in the Pulp and Paper Industry (Final Report). Princeton: Princeton University, 2003.

[2] Larson, E.D.; R.E. Katofsky. Production of Hydrogen and Methanol from Biomass. Princeton: Princeton University, 1992.

[3] The UK's National Centre for Biorenewable Energy, Fuels and Materials. Review of Technologies for Gasification of Biomass and Wastes, 2009.

[4] Morehead, H. Siemens Gasification and IGCC Update. Flórida, 2008.

[5] Biague, M.F. Modelagem da Carteira dos Recursos Energéticos do PIR: Validação do Modelo no PIR de Araçatuba. 2010. Tese de Doutorado - Escola Politécnica, Universidade de São Paulo, São Paulo, 2010.

[6] Baitelo, R.L. Modelo de Valoração e Cômputo de Potenciais Completos de Recursos Energéticos para o PIR. 2009. Tese de Doutorado - Escola Politécnica, Universidade de São Paulo, São Paulo, 2009.

[7] Velázquez, S.M.S.G. Perspectivas para a geração de excedentes de energia elétrica no segmento de papel e celulose com a utilização de sistemas de gaseificação/turbina a gás. 2006. Tese de Doutorado Universidade de São Paulo, São Paulo, 2006.

[8] Basu, P. Biomass Gasification and Pyrolysis. Academic Press, 2010, 376p.

[9] BRASIL. Operador Nacional do Sistema Elétrico. Capacidade Instalada por Tipo de Geração. Disponível em:

http://www.ons.org.br/download/biblioteca virtual/publicacoes/dados relevant es 2009/07-Capacidade-Instalada-por-Tipo-de-Geracao-MW.html. Acesso em 25 ab. 2011.

[10] BRASIL. Agência Nacional de Energia Elétrica. Disponível em:

http://www.aneel.gov.br. Acessos em 2011/2012. 
[11] BRASIL. Empresa de Pesquisa Energética. Balanço Energético Nacional 2010 ano base 2009. Disponível em https://ben.epe.gov.br. Acesso em 26 fev. 2012.

[12] Nagai, S. Trilhas de Sustentabilidade do Setor de Celulose e Papel. Bracelpa: São Paulo, Junho, 2009.

[13] SÃO PAULO (Estado). Fundação Sistema Estadual de Análise de Dados. Banco de dados. Disponível em http://www.seade.gov.br. Acessos em 2011/2012.

[14] BRASIL. Instituto Brasileiro de Geografia e Estatística. Banco de dados. Disponível em http://www.ibge.gov.br. Acessos em 2011/2012.

[15] Suzano (Município). Disponível em http://www.suzano.sp.gov.br. Acesso em abril 2011.

[16] SÃO PAULO (Estado). Companhia de Saneamento Básico do Estado de São Paulo. Disponível em http://site.sabesp.com.br/site/interna/Municipio.aspx?secaold=18\&id=120. Acesso em abril 2011.

[17] Suzano Papel e Celulose. Relatório de Sustentabilidade 2009. Relatório. Suzano, 2010. 136p.

[18] Ferreira, P.R.P. Caracterização das Leis Hídricas do Brazil. Campinas, 2003.

[19] Suzano (Município). Revisão do Plano Diretor de Suzano 2006 - 2016. Plano Diretor. Suzano, 2007. 102p.

[20] Suzano (Município). Elaboração de Plano de Redução de Riscos no Município de Suzano (SP). Relatório Suzano: Prefeitura de Suzano, 2006. $36 \mathrm{p}$.

[21] Pfeiffer, E.; Ven M.V. Developments in Fluid Bed Combustion and Gasification. In: Workshop IEA task 32, Hamburg, 2009. 
[22] Schuck, S. Submission for Inquiry into Growing Australizan Forestry. Publicação eletrônica. Mensagem recebida por arff.reps@aph.gov.au, em 25 de mar. 2011.

[23] NNFCC. Review of Technologies for Gasification of Biomass and Wastes. Relatório Técnico. Inglaterra, 2009.

[24] SÃO PAULO (Estado). Companhia Ambiental do Estado de São Paulo. Relatório do inventário estadual de fontes fixas emissões de $\mathrm{CO}_{2}-$ fontes industriais - combustíveis fósseis. Relatório Técnico. São Paulo: CETESB, 2008.

[25] SÃO PAULO (Estado). Companhia Ambiental do Estado de São Paulo. Qualidade do Ar no Estado de São Paulo. Relatório Técnico. São Paulo: CETESB, 2010. 237p.

[26] SÃO PAULO (Estado). Empresa Paulista de Planejamento Metropolitano S.A. Mapa da Região Metropolitana de São Paulo. Disponível em http://www.emplasa.sp.gov.br. Acesso em 15 jun. 2011.

[27] CBC Indústrias Pesadas S/A. Disponível em: http://www.cbcsa.com.br/caldeiraqui.asp. Acesso em 20 jun. 2011.

[28] Juliano, R. A. P.; Iwamoto F. Análise da Bioenegia do Oeste Paulista Através do Planejamento Integrado de Recursos Energéticos. 2009. Projeto de formatura Universidade de São Paulo, São Paulo, 2009.

[29] SÃO PAULO (Estado). Departamento de Águas e Energia Elétrica. Disponível em http://www.rededasaguas.org.br/nucleo/alto tiete.htm. Acesso em jul. 2011.

[30] SÃO PAULO (Estado). Departamento de Águas e Energia Elétrica. Mapa de Águas Subterrâneas do Estado de São Paulo. Nota explicativa, 2005.

[31] BRASIL. Departamento Nacional de Trânsito. Disponível em http://www.denatran.gov.br. Acesso em 2011.

[32] SÃO PAULO (Estado). Centro de Monitoramento e Mitigação da Seca e 
Adversidades Hidrometeorologicas. Disponível em http://www.infoseca.sp.gov.br. Acesso em 2011.

[33] Centro de Referência para Energia Solar e Eólica Sergio de Salvo Brito. Atlas do Potencial Eólico Brasileiro, 2001. Disponível em http://www.cresesb.cepel.br/atlas eolico. Acesso em 2011.

[34] SÃO PAULO (Estado). Secretaria de Meio Ambiente do Estado de São Paulo. Relatório de Qualidade Ambiental. Relatório. São Paulo: SMA, 2007.

[35] SÃO PAULO (Estado). Companhia Ambiental do Estado de São Paulo. Qualidade das Águas Subterrâneas no Estado de São Paulo 2007-2009. Relatório Técnico. São Paulo: CETESB, 2010. 260p.

[36] Qualidade das Águas Superficiais no Estado de São Paulo 2010. Relatório Técnico. São Paulo: CETESB, 2011. 300p.

[37] Inventário Estadual de Resíduos Sólidos Domiciliares. Relatório Técnico. São Paulo: CETESB, 2011. 186p.

[38] EDP Bandeirante. Área de concessão. Disponível em http://www.bandeirante.com.br. Acesso em 2012.

[39] Suzano Papel e Celulose. O Processo de Produção de Celulose e do Papel. Disponível em http://ri.suzano.com.br/ .Acesso em 2011

[40] Associação Brasileira de Papel e Celulose. Relatório de Sustentabilidade 2010. Relatório: Relatório. São Paulo: Bracelpa, 46p.

[41] Bracelpa Associação Brasileira de Papel e Celulose. Relatório Estatístico 2010/2011. Relatório. São Paulo: Bracelpa, 49p.

[42] Dados do setor - Março de 2012. Relatório.São Paulo: Bracelpa, $28 p$.

[43] Resultados de 2010 e Perspectivas. São Paulo, 2010. Disponível em http://www.bracelpa.org.br. Acesso em 2012. 
[44] SÃO PAULO (Estado). Companhia de Tecnologia de Saneamento Ambiental. Qualidade do Ar no Estado de São Paulo. Relatório Técnico. São Paulo: CETESB, 2011. 124p.

[45] 10 Inventário de Emissões Antrópicas de Gases de Efeito Estufa Diretos e Indiretos do Estado de São Paulo. Relatório Técnico. São Paulo: CETESB, 2011. 195p.

[46] SÃO PAULO (Estado). Companhia de Saneamento Básico do Estado de São Paulo. Relatório de Qualidade das Águas Superficiais. São Paulo: Série Relatórios: SABESP, 2011. 342p.

[47] Suzano Papel e Celulose. Relatório de Sustentabilidade 2011. Relatório. Suzano, 2012. 108p.

[48] SÃO PAULO (Estado). Companhia de Saneamento Básico do Estado de São Paulo. Relatório de Qualidade das Águas Interiores do Estado de São Paulo. São Paulo: Série Relatórios: SABESP, 2008. 531p.

[49] SÃO PAULO (ESTADO). Secretaria do Meio Ambiente do Estado de São Paulo. Relatório de Qualidade Ambiental. São Paulo: Série Relatórios: SMA, 2011. 258p

[50] Silva, J. Análise Termoeconômico do Processo de Geração de Vapor e Potência do Segmento de Celulose e Papel. 2002. Dissertação de Mestrado da Universidade Federal de Itajubá, Minas Gerais, 2002.

[51] Consórcio Capim Branco Energia. Disponível em http://www.ccbe.com.br/home. Acesso em jun. 2012.

[52] Piotto, Z. C. Eco-eficiência na Indústria de Celulose e Papel - Estudo de caso. 2003. 379f. Tese de Doutorado, Universidade de São Paulo, São Paulo, 2003.

[53] Mieli, J. C. de A. Sistemas de Avaliação Ambiental na Indústria de Celulose e Papel. 2007. 111 f. Tese de doutorado, Universidade Federal de Viçosa, Minas Gerais, 2007. 
[54] Berni, M.D.; Pagliardi O.; Bordoni, O.F. Mecanismos de Incentivo à Eficiência Energética no Setor de Celulose e Papel para Economia de Baixo Carbono. In: $43^{\circ}$ Congresso e Esposição Internacional de Celulose e Papel. Apresentação. São Paulo, 2010. 49p

[55] Udaeta, M. E. M. et al. Relatório Técnico Científico de Inventário Energo-Ambiental da Região Administrativa de Araçatuba, nos meios Antrópico, Aéreo, Aquático e Terrestre, definidos no PIR, visando os impactos globais dos empreendimentos energéticos. Relatório Técnico Científico. FAPESP no 03/06441-7. São Paulo: FAPESP/USP, 2009.

[56] Relatório Técnico Científico de Mapeamento Energo-Ambiental de Indicadores Para o PIR da RAA. Relatório Técnico Científico. FAPESP no 03/06441-7. São Paulo: FAPESP/USP, 2009.

[57] Relatório Técnico Científico de Plano Preferencial Integrado de Recursos Energéticos (RELOs e RELDs) no PIR da RAA. Relatório Técnico Científico. FAPESP no 03/06441-7. São Paulo: FAPESP/USP, 2010.

[58] Relatório Técnico Científico de Cenários Socioeconômicos Visando a Previsão de Demanda no Contexto do PIR para a RAA. Relatório Técnico Científico. FAPESP no 03/06441-7. São Paulo: FAPESP/USP, 2009.

[59] Relatório Técnico Científico de Aplicação de ACC Completa dentro do PIR da RAA. Relatório Técnico Científico. FAPESP no 03/06441-7. São Paulo: FAPESP/USP, 2009.

[60] Relatório Técnico Científico de Efeitos Regionais na Saúde Humana devido ao Uso dos Recursos Energéticos dentro do PIR para a RAA/SP. Relatório Técnico Científico. FAPESP no 03/06441-7. São Paulo: FAPESP/USP, 2009.

[61] Relatório Técnico Científico de Análise do Ranqueamento Final dos Recursos Energéticos de Oferta e Demanda do PIR. Relatório Técnico Científico. FAPESP no 03/06441-7. São Paulo: FAPESP/USP, 2009. 
[62] Obernberger I., Thek G. Combustion and Gasification of Solid Biomass for Heat and Power Production in Europe - State of the art and Relevant Future Developments. Relatório Técnico Científico. Portugal: 2008 


\section{Apêndices}

No apêndice A temos a planilha do RELO’s determinística e no apêndice B temos a planilha dos RELO's holística. Sem estas planilhas não é possilvel realizar o ranqueamento dos recursos.

Como explicado no capítulo 7 a planilha determinística é provinda de dados de valoração resultantes do capítulo 6 enquanto que o holítico e provindo de dados dos especialista e En-In.

Nestas planilhas todos os recursos são valorados em suas dimensões (técnico-econômica, ambiental, social e política) com seus respectivos atributos e subatributos.

Os valores destas planilhas já passaram por um processo de "rating" [61], sendo normalizado para valores entre 0 e 1 . Isto deve ser feito para poder comparar subatributos de escalas diferentes (Ex: comparar vida útil em anos, e custo de operação e manutenção em R\$/MWh). 
APÊNDICE A

Tabela 52 - Planilha dos RELOs (Deteminística)

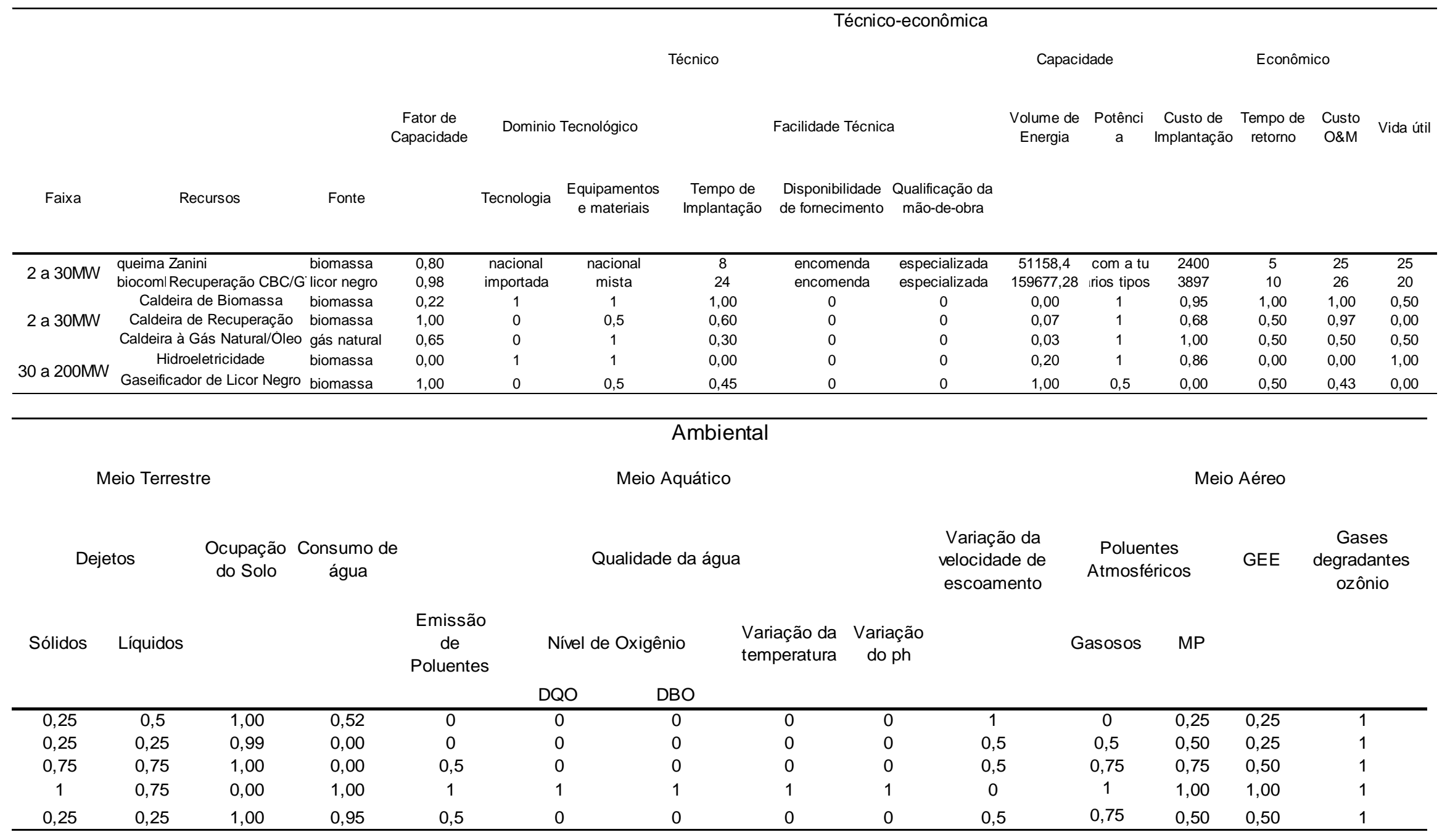

(Continua pág. seguinte) 
Tabela 53 - Planilha dos RELOs (Deteminística)

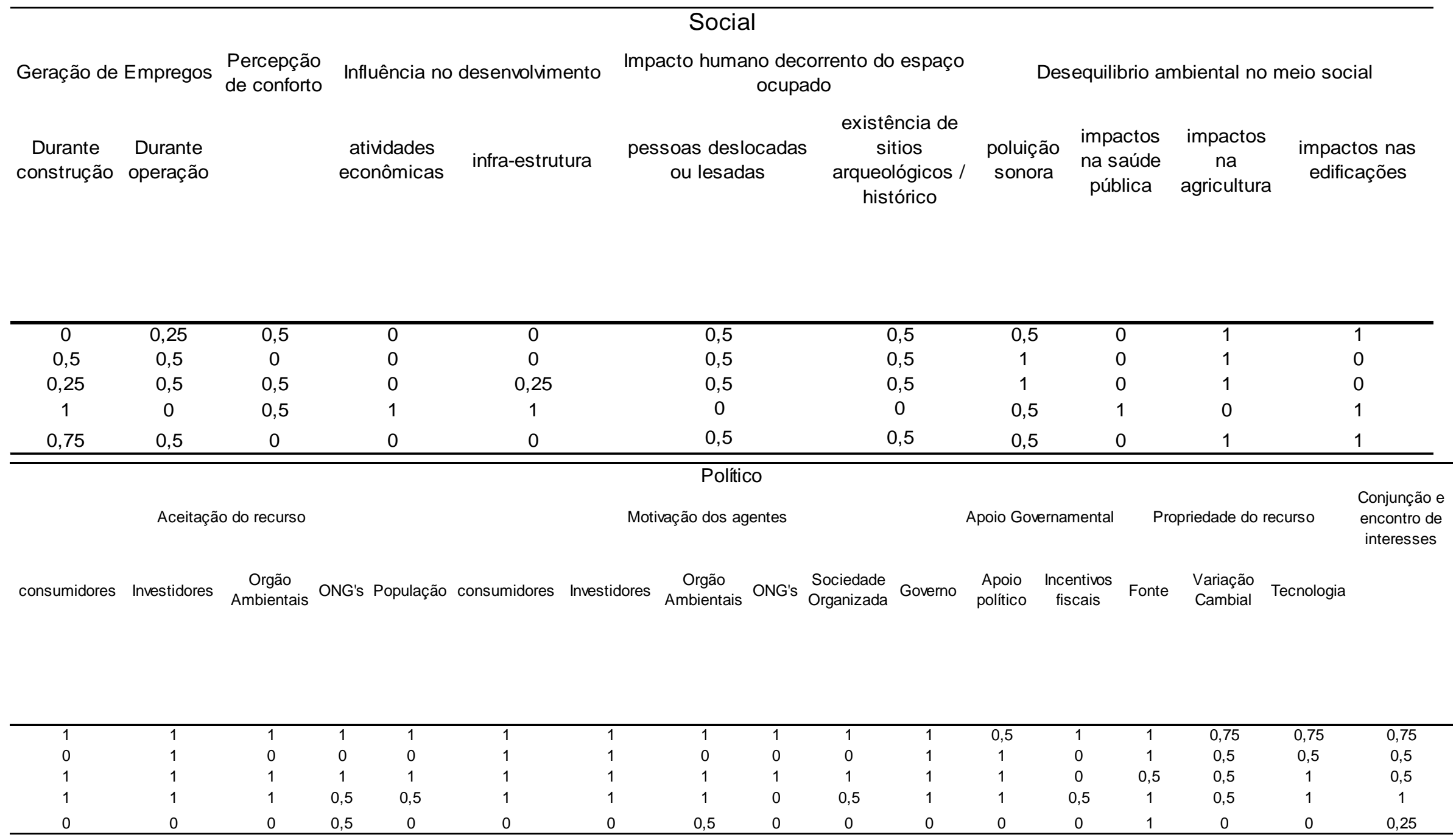

Fonte: Elaboração própria 


\section{APÊNDICE B}

Tabela 54 - Planilha RELOs (Holística)

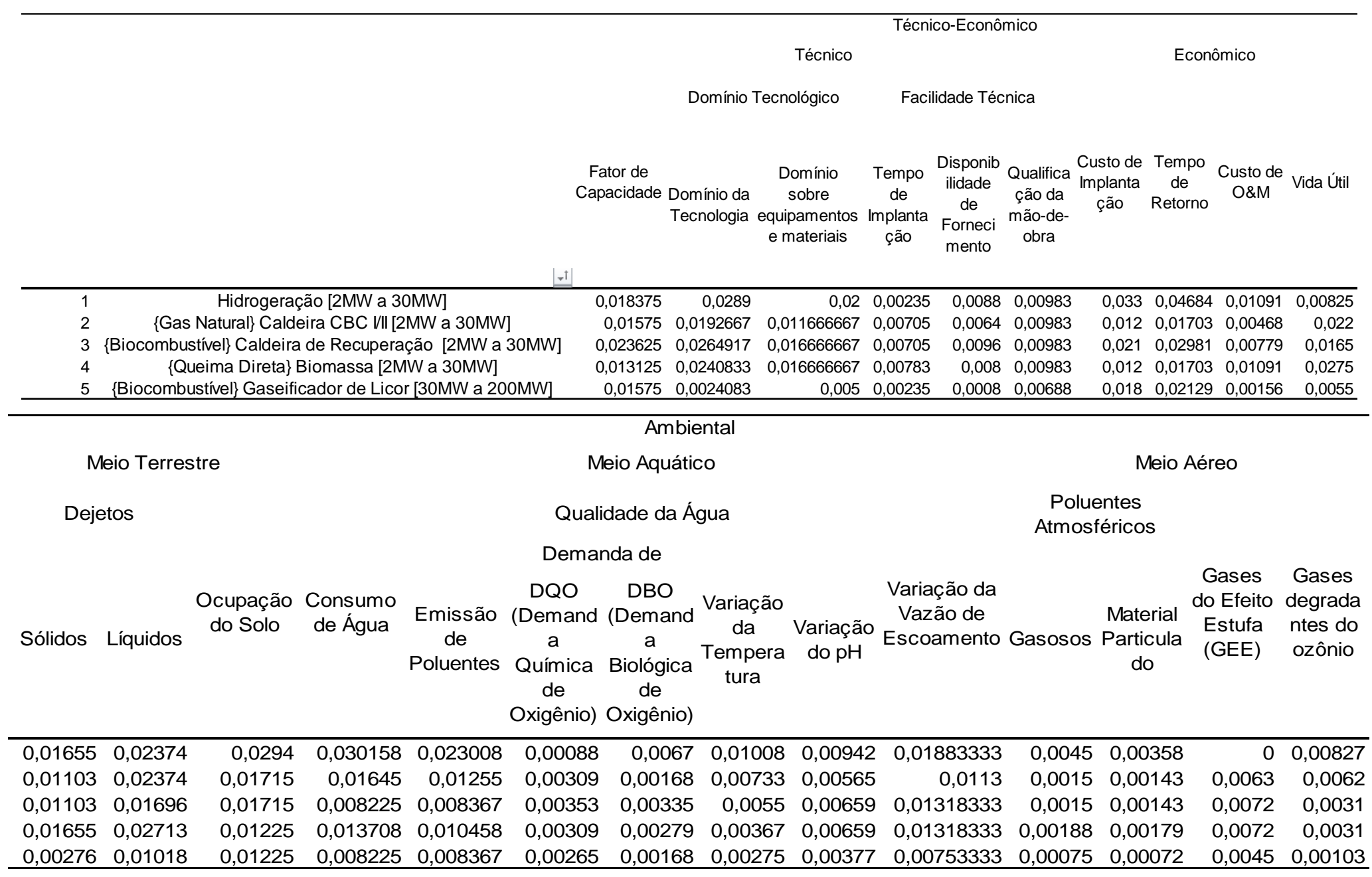

(Continua pág. seguinte) 
Tabela 55 - Planilha RELOs (Holística)

\begin{tabular}{|c|c|c|c|c|c|c|c|c|c|c|}
\hline \multicolumn{3}{|c|}{$\begin{array}{l}\text { Geração de } \\
\text { Empregos }\end{array}$} & \multicolumn{2}{|c|}{$\begin{array}{c}\text { Influência no } \\
\text { Desenvolvimento }\end{array}$} & \multicolumn{2}{|c|}{$\begin{array}{l}\text { Social } \\
\text { Impacto humano } \\
\text { decorrente do espaço }\end{array}$} & \multicolumn{4}{|c|}{ Desequilibrio Ambiental no meio Social } \\
\hline $\begin{array}{l}\text { Durante } \\
\text { a } \\
\text { Constru } \\
\text { ção }\end{array}$ & $\begin{array}{l}\text { Durante a } \\
\text { Operação }\end{array}$ & $\begin{array}{l}\text { Percepç } \\
\text { ão de } \\
\text { Conforto }\end{array}$ & $\begin{array}{l}\text { Influência } \\
\text { nas } \\
\text { atividades } \\
\text { econômicas }\end{array}$ & $\begin{array}{l}\text { Influência } \\
\text { na infra- } \\
\text { estrutura }\end{array}$ & $\begin{array}{c}\text { Pessoas } \\
\text { deslocada } \\
\text { s ou } \\
\text { lesadas }\end{array}$ & $\begin{array}{l}\text { Existênci } \\
\text { as de } \\
\text { sítios } \\
\text { arqueológ } \\
\text { icos / } \\
\text { históricos }\end{array}$ & $\begin{array}{l}\text { Poluição } \\
\text { Sonora }\end{array}$ & $\begin{array}{l}\text { Impacto } \\
\text { s na } \\
\text { Saúde } \\
\text { Pública }\end{array}$ & $\begin{array}{l}\text { Impactos } \\
\text { na } \\
\text { Agricultura }\end{array}$ & $\begin{array}{l}\text { Impactos } \\
\text { nas } \\
\text { Edificações }\end{array}$ \\
\hline 0,0224 & 0,043467 & 0,01852 & 0,0297 & 0,0054 & 0,0186083 & 0,008175 & 0,0036 & 0,00413 & 0 & 0,0066667 \\
\hline 0,00933 & 0,027167 & 0,01347 & 0,0198 & 0,0072 & 0,0118417 & 0,00545 & 0,00225 & 0,02067 & 0,007867 & 0,002 \\
\hline 0,00933 & 0,0163 & 0,01347 & 0,0231 & 0,0072 & 0,0067667 & 0,004542 & 0,0018 & 0,02067 & 0,00885 & 0,0033333 \\
\hline 0,00373 & 0,0163 & 0,01347 & 0,0165 & 0,009 & 0,0067667 & 0,002725 & 0,00135 & 0,02067 & 0,00885 & 0,002 \\
\hline 0,00747 & 0,0163 & 0,01178 & 0,0132 & 0,0054 & 0,005075 & ; 0,001817 & 0,0009 & 0,01447 & 0,0059 & 0,002 \\
\hline
\end{tabular}

\begin{tabular}{|c|c|c|c|c|c|c|c|c|c|c|c|c|c|c|c|}
\hline & Aceitaç & ção do $R \epsilon$ & Recurso & & & & Motivação & $\begin{array}{c}\text { Político } \\
\text { dos Agente }\end{array}$ & & & $\begin{array}{r}\text { Ap } \\
\text { Govern }\end{array}$ & $\begin{array}{l}\text { soio } \\
\text { lamental }\end{array}$ & Propried & dade do $\mathrm{R} \in$ & Securso \\
\hline $\begin{array}{l}\text { Consumi II } \\
\text { dores }\end{array}$ & $\begin{array}{l}\text { Investido } \\
\text { res }\end{array}$ & $\begin{array}{l}\text { Orgão } \\
\text { Ambien } \\
\text { tais }\end{array}$ & $\begin{array}{l}\text { Aceitação } \\
\text { das } \\
\text { ONG's }\end{array}$ & $\begin{array}{l}\text { Aceitaçã } \\
\text { o da } \\
\text { Populaç } \\
\text { ão }\end{array}$ & $\begin{array}{l}\text { Consumi } \\
\text { dores }\end{array}$ & $\begin{array}{l}\text { Investido } \\
\text { res }\end{array}$ & $\begin{array}{l}\text { Orgão } \\
\text { Ambien } \\
\text { tais }\end{array}$ & $\begin{array}{c}\text { Motivação } \\
\text { das } \\
\text { ONG's }\end{array}$ & $\begin{array}{l}\text { Motivação } \\
\text { da } \\
\text { Sociedad } \\
\text { e } \\
\text { Organiza } \\
\text { da }\end{array}$ & $\begin{array}{l}\text { Motivação } \\
\text { do } \\
\text { Governo }\end{array}$ & $\begin{array}{l}\text { Apoio } \\
\text { Político }\end{array}$ & $\begin{array}{l}\text { Incentivos } \\
\text { Fiscais }\end{array}$ & $\begin{array}{l}\text { Propriedade } \\
\text { de Fonte }\end{array}$ & $\begin{array}{l}\text { Variação } \\
\text { Cambial }\end{array}$ & $\begin{array}{c}\text { Propriedade } \\
\text { da } \\
\text { Tecnologia }\end{array}$ \\
\hline 0,013 & 0,00408 & 0,0059 & 0,003417 & 0,01223 & 0,00546 & 0,00265 & 50,0058 & 0,003525 & 0,006167 & 0,0038 & 0,0074 & 0,034942 & 0,0165 & 0,00889 & 0,0105833 \\
\hline 0,0078 & 0,00572 & 0,0079 & 0,003075 & 0,01494 & 0,00764 & 0,00442 & 0,0068 & 0,001958 & 0,004317 & 0,0076 & 0,0148 & 0,034942 & 0,009 & 0,00566 & 0,0042333 \\
\hline 0,0065 & 0,00408 & 0,0079 & 0,003758 & 0,00951 & 0,00437 & 0,00353 & 0,0058 & 0,003133 & 0,006783 & 0,0038 & 0,0074 & 0,019967 & 0,015 & 0,00485 & 0,0052917 \\
\hline 0,0052 & 0,00408 & 0,0089 & 0,002733 & 0,01358 & 0,00437 & 0,00353 & 0,0039 & 0,00235 & 0,00555 & 0,005067 & 0,01233 & 0,014975 & 0,009 & 0,00485 & 0,0052917 \\
\hline 0,0052 & 0,00245 & 0,0059 & 0,00205 & 0,00951 & 0,00218 & 0,00353 & 0,0029 & 0,001567 & 0,0037 & 0,0038 & 0,0074 & 0,009983 & 0,006 & 0,00162 & 0,0021167 \\
\hline
\end{tabular}

Fonte: Elaboração própria 